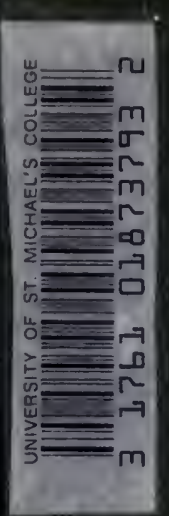




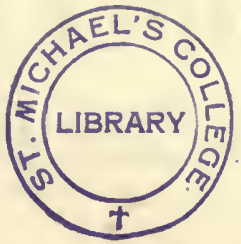

DEC 21940 


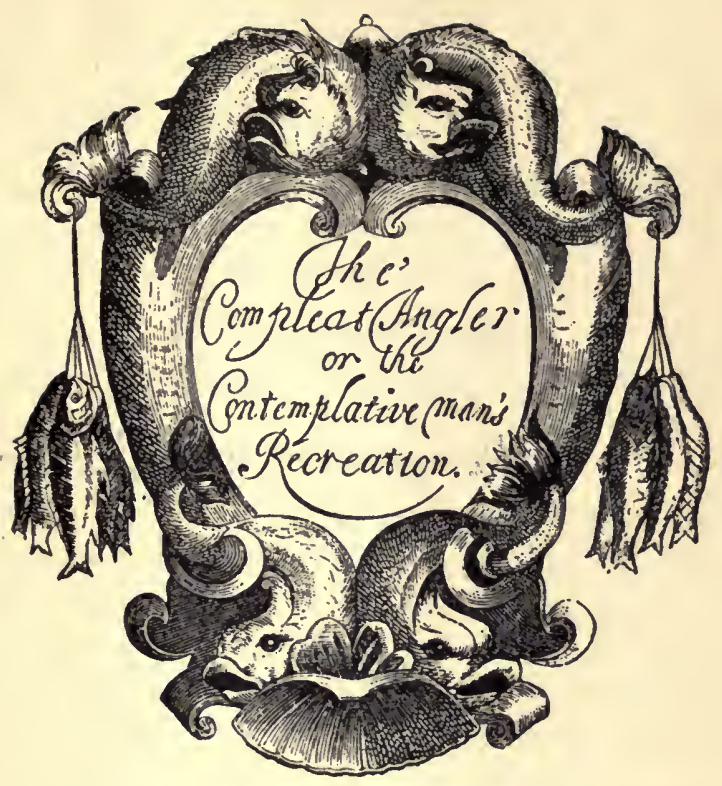

Being a Difcourfe of

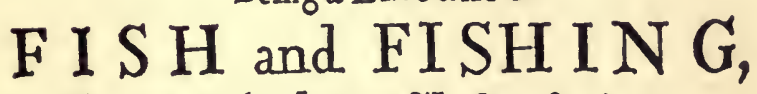
Not unw or thy the perufal of moit. Anglers.

Sim on Peter faid, I go a frhing: and tbey faid, We alfowil go with thee. John 21.3.

Iondon, Printed by T. Maxey for Rich, MARRIOT, in S. Dunftans Church-yard. Flectfreet, 2653.

[Fac-simile of Tille-page of the orlginal Edition.] 


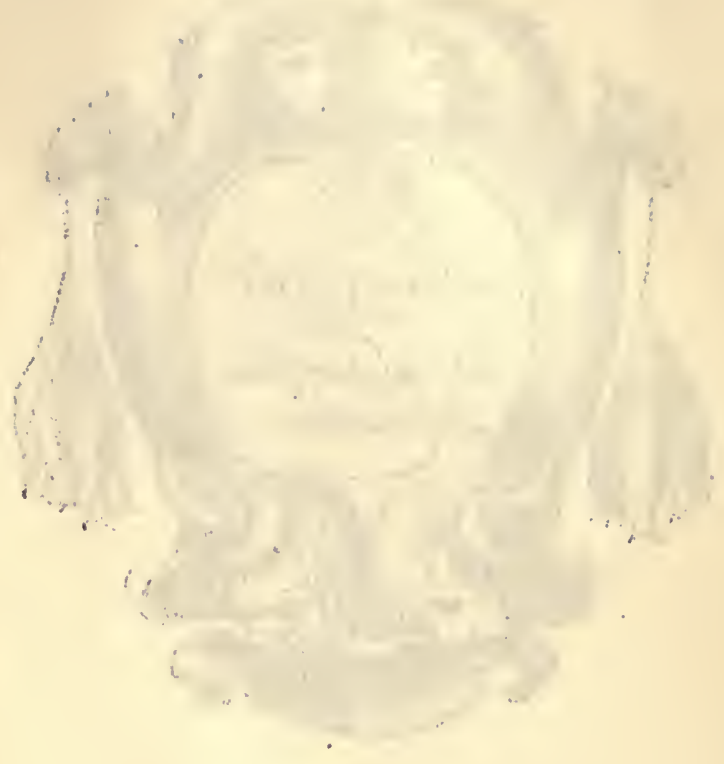

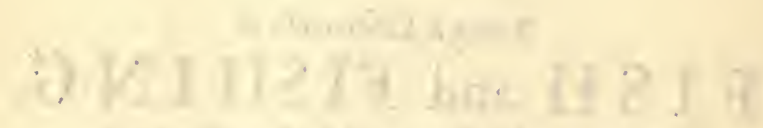

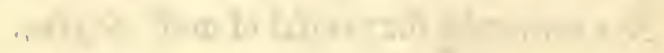

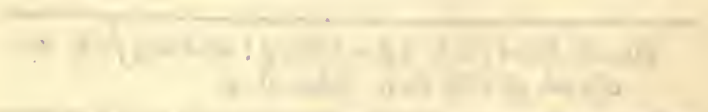

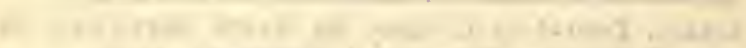

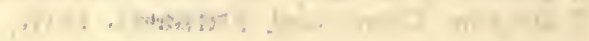

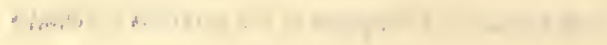
4 


\section{THE EPISTLE DEDICATORY}

TO THE RIGHT WORSHIPFUL

JOHN OFFLEY, EsQ.,

OF MADELEY MANOR, IN THE COUNTY OF STAFFORD

My most honoured Friend,

SiR, - I have made so ill use of your former favours, as by them to be encouraged to entreat, that they may be enlarged to the patronage and protection of this book: and I have put on a modest confidence, that, I shall not be denied, because it is a discourse of fish and fishing, which you know so well, and both love and practise so much.

You are assured, though there be ignorant men of another belief, that angling is an art: and you know that art better than others; and that this truth is demonstrated by the fruits of that pleasant labour which you enjoy, when you purpose to give rest to your mind, and divest yourself of your more serious business, and (which is often) dedicate a day or two to this recreation.

At which time, if common Anglers should attend you, and be eye-witnesses of the success, not of your fortune but your skill, it would doubtless beget in them an emulation to be like you, and that emulation might beget an industrious diligence to be so; but $I$ know it is not attainable by conmon capacities. And there be now many men of great wisclom, learning, and experience, which love and practise this art, that know I speak the truth.

$100-A^{*}$ 
Sir, this pleasant curiosity of fish and fishing, of which you are so great a master, has been thought worthy the pens and practices of divers in other nations, that have been reputed men of great learning and wisdom; and amongst those of this nation, I remember Sir Henry Wotton (a dear lover of this art) has told me, that lis intentions were to write a discourse of the art, and in praise of angling; and doubtless he had done so, if death had not prevented him; the remembrance of which hath often made me sorry; for if he had lived to do it, then the unlearned angler had seen some better treatise of this art, a treatise that might have proved worthy his perusal, which, though some have undertaken, I could never yet see in English.

But mine may be thought as weak, and as unworthy of common view; and I do here freely confess, that I should rather excuse myself, than censure others, my own discourse being liable to so many exceptions; against which you, sir, might make this one, that it can contribute nothing to your knowledge. And lest a longer epistle may diminish your pleasure, I shall make this no longer than to add this following truth, that I am really,

\section{Sir,}

Your most affectionate friend, And most humble servant, 


\section{TO THE READER OF THIS DISCOURSE}

\section{BUT ESPECIALLY \\ TO THE HONEST ANGLER}

I THINk fit to tell thee these following truths, that I did neither undertake, nor write, nor publish, and much less own, this Discourse to please myself ; and, having been too easily drawn to do all to please others, as I propose not the gaining of credit by this undertaking, so I would not willingly lose any part of that to which I had a just title before I began it, and do therefore desire and hope, if I deserve not commendations, yet I may obtain pardon.

And though this Discourse may be liable to some exceptions, yet I cannot doubt but that most readers may receive so much pleasure or profit by it, as may make it worthy the time of their perusal, if they be not too grave or too busy men. And this is all the confidence that I can put on, concerning the merit of what is here offered to their consideration and censure; and if the last prove too severe, as I have a liberty, so I am resolved to use it, and neglect all sour censures.

And I wish the reader also to take notice, that in writing of it I have made myself a recreation of a recreation; and that it might prove so to him, and not read dull and tediously, I have in several places mixed, not any scurrility, but some innocent, harmless mirth, of which, if thou be a severe, sour-complexioned man, then I here disallow thee to be a competent judge; for divines say, there are offences given, and offences not given but taken. 
And I am the willinger to justify the pleasant part of it, because though it is known I can be serious at seasonable times, yet the whole Discourse is, or rather was, a picture of my own disposition, especially in such days and times as I have laid aside business, and gone a-fishing with honest Nat and R. Roe; but they are gone, and with them most of my pleasant hours, even as a shadow that passeth away and returns not.

And next let me add this, that he that likes not the book should like the excellent picture of the trout, and some of the other fish; which I may take a liberty to commend, because they concern not myself.

Next let me tell the reader, that in that which is the more useful part of this Discourse, that is to say, the observations of the nature, and breeding, and seasons, and catching of fish, I am not so simple as not to know that a captious reader may find exceptions against something said of some of these; and therefore I must entreat him to consider, that experience teaches us to know that several countries alter the time, and I think almost the manner of fishes' breeding, but doubtless of their being in season; as may appear by three rivers in Monmouthshire, namely, Severn, Wye, and Usk, where Camden (Brit. Fishes, 633) observes, that in the River Wye, salmon are in season from September to April; and we are certain that in Thames and Trent, and in most other rivers, they be in season the six hotter months.

Now for the art of catching fish, that is to say, how to make a man-that was none-to be an angler by a book ; he that undertakes it, shall undertake a harder task than Mr. Hales, a most valiant and excellent fencer, who, in a printed book called $A$ Private School of Defence, undertook to teach that art or science, and was laughed at for his labour-not but that many useful things might be learnt by that book, but he was laughed at because that art was not to be taught by words, but 
practice; and so must angling. And note also that in this Discourse I do not undertake to say all that is known, or may be said of it, but I undertake to acquaint the reader with many things that are not usually known to every angler ; and I shall leave gleanings and observations enough, to be made out of the experience of all that love and practise this recreation, to which I shall encourage them. For angling may be said to be so like the mathematics, that it can never be fully learnt; at least not so fully, but that there will still be more new experiments left for the trial of other men that succeed us.

But I think all that love this game may here learn something that may be worth their money, if they be not poor and needy men; and in case they be, I then wish them to forbear to buy it, for I write not to get money, but for pleasure, and this Discourse boasts of no more; for I hate to promise much and deceive the reader.

And however it proves to him, yet I am sure I have found a high content in the search and conference of what is here offered to the reader's view and censure : I wish him as much in the perusal of it, and so I might here take my leave; but will stay a little and tell him, that whereas it is said by many that in fly-fishing for a trout the angler must observe his twelve several flies for the twelve months of the year: I say, he that follows that rule shall be as sure to catch fish, and be as wise, as he that makes hay by the fair days in an almanac, and no surer; for those very flies that use to appear about and on the water in one month of the year, may the following year come almost a month sooner or later, as the same year proves colder or hotter; and yet, in the following Discourse, I have set down the twelve flies that are in reputation with many anglers, and they may serve to give him some observations concerning 
them. And he may note, that there are in Wales and other countries, peculiar flies, proper to the particular place or country; and doubtless, unless a man makes a fly to counterfeit that very fly in that place, he is like to lose his labour, or much of it ; but for the generality, three or four flies, neat and rightly made, and not too big, serve for a trout in most rivers all the summer. And for winter fly-fishing-it is as useful as an almanac out of date! And of these, because as no man is born an artist, so no man is born an angler, I thought fit to give thee this notice.

When I have told the reader, that in this fifth impression there are many enlargements, gathered both by my own observation and the communication with friends, I shall stay him no longer than to wish him a rainy evening to read this following Discourse; and that, if he be an honest angler, the east wind may never blow when he goes a-fishing.

I. W. 


\title{
CONTENTS
}

\author{
PART I
}

Jirst Đą

ChAPTER

PAGE

1. A Dialogue between Piscator (an Angler), Venaton (a Hunter), and AucePs (a Falconer).

ฐecorto Фay

2. Of the OTтER, Otter-hunting, and Observations about the Habits of the CHUB . . . . .

\section{Tbiro Фav}

3. How to fish for and cook the Chavenden or Chus .

4. Observations of the Nature and Breeding of the Trour, and how to fish for him; and the Milk-maid's Song

5. More Directions how to fish for, and how to make for the Tnour an artificial Minnow and Flies; with some Mcrriment . . . . . . . .

\section{Jourtb Day}

6. Observations of the Umber or Graylina ; and Directions how to fish for him . . . . . .

7. Obscrvations of the SALMoN; with Directions how to fish for him.

8. Observations of the Luce or Prke; with Directions how to fish for him . . . . . . . .

9. Observations of the CARP; with Directions how to fish for him . . . . . . . . . .

10. Observations of the BreaM; and Directions to catch him

11. Observations of the TENCH; and Advice how to angle for him

12. Observations of the PEncH; and Directions how to fish for him 
CIIAPTER

PAGE

13. Observations of the EEL, and other Fish that want Scales : and how to fish for them . . .

14. Observations of the BARBEL; and Directions how to fish for him

15. Observations of the Gudgeos, the RuFfe, and the BLEAK ; and how to fish for them . . . . 193

16. Is of Nothing, or that which is Nothing worth : • . 198

\section{Jiftb (last) Đay}

17. Of RoAcrr and DACE, and how to flsh for them; and of y Cadis

18. Of the Minsow or PENK, of the LOACH, and of the BullHeAd or Millek's THumb . . . . . 219

19. Of several Rivers ; and some Observations of Fish . . 224

20. Of Fish-Ponds, and how to order them . . . . 228

21. Directions for making of a Line, and for the colouring of both Rod and Line . . . . .

BEING LNSTTRUCTIONS HOW TO ANGLE FOR TROUT OR GRAYLING IN A CLEAR STREAM

\section{Jitst Фap}

A. Dialogue : between PIscator Junion (Cotton) and
Viator (the Venator of the First Part of the Bonk).
All these Chapters are initiatory, chieny descriptive
3.
of the River Dove and other vicinous Rivers, and of
Beresford . . . . .

\section{ฐecollo Day}

2.4. Angling at the "Top," at the "Middle," and at the "Bottom"

5. Of Fijy-Fishíng and Fly-Making . 275

6. A practical Lesson on Fly-Fishing for Trout and Grayling 276

7. Lists of Artifieial Flies for the Montlis of January, f. February, Mareh, April, and May; showing also liow" to dib or dape witli the Green-Drake or MlayFly, and how to make that famous Fly artificially. 
CIIAPTER

PAGE

8. Of the Stone-Fly; also a List of Flies for June, July, August, September, October. November, and December: with some good Remarks on the Green-Drake and Stone-Fly, and on Poaching .

\section{Tbird (last) Фay}

9. A short Dialogue, and a Lapse in Angling on the Part of Piscator. Viator Fishes successfully by himself . 320

10. Showing how Trout and Grayling are best cooked . $\quad 322$

11. Teaches the Art of Angling at the Bottom with Worms, Grubs, and Cadis

12. Contains Directions touching Angling at the Middle with a Minnow for Trout, and with a Worm, Grub, or Cadis for a Grayling. Farewell between Piscaton JUNion and ViATOR

N.B.-The notes signed "H." are from Sir John Hawkins's edition of Walton: those with " $E$." are from that edited by "Ephemera" in 1853. 



\section{THE COMPLETE ANGLER}

\section{PART THE FIRST}

\section{CHAPTER $^{\circ}$ I}

CONFERENCE BETWIXT AN ANGLER, A HUNTER, AND A FALCONER; EACH COMMENDING HIS RECREATION

\section{[Jirst Day]}

\section{Piscator, Venator, Auceps}

Piscator. You are well overtaken, gentlemen, a good morning to you both; I have stretched my legs up Tottenham Hill to overtake you, hoping your business may occasion you towards Ware, whither I am going this fine, fresh May morning.

Venator. Sir, I for my part shall almost answer your hopes ; for my purpose is to drink my morning's draught at the Thatched House in Hoddesden, and I think not to rest till I come thither, where I have appointed a friend or two to meet me: but for this gentleman that you see with me, I know not how far he intends his journey; he came so lately into my company, that I have scarce had time to ask him the question.

Auceps. Sir, I shall by your favour bear you company as far as Theobald's, * and there leave you; for then I turn up to a friend's house who mews a hawk for me, which I now long to see.

* A house built by Lord Burleigh, in Herts, and by his son, an Earl of Salisbury, exehanged with James I. for Hatfield House. 
VEN. Sir, we are all so happy as to have a fine, fresh, cool morning; and I hope we shall each be the happier in the other's company. And, gentlemen, that I may not lose yours, I shall either abate or amend my pace to enjoy it; knowing that, as the Italians say, "Good company in a journey makes the way to seem the shorter."

Auc. It may do so, Sir, with the help of good discourse, which methinks we may promise from you that both look and speak so cheerfully; and for my part I promise you, as an invitation to it, that $I$ will be as free and open-hearted, as discretion will allow me to be with strangers.

VEN. And, Sir, I promise the like.

Pisc. I am right glad to hear your answers, and in confidence you speak the truth. I shall put on a boldness to ask you, Sir, whether business or pleasure caused you to be so early up, and walk so fast; for this other gentleman hath declared that he is going to see a hawk that a friend mews for him.

VEN. Sir, mine is a mixture of both, a little business and more pleasure; for I intend this day to do all my business, and then bestow another day or two in hunting the Otter, which a friend, that I go to meet, tells me is much pleasanter than any other chase whatsoever: howsoever, I mean to try it; for to-morrow morning we shall meet a pack of Otter-dogs : of noble $\cdot$ Mr. Sadler's, upon Amwell Hill, who will be there so early that they intend to prevent [forestall] the sun-rising.

PIsc. Sir, my fortune las answered my desires, and my purpose is to bestow a day or two in helping to destroy some of those villanous vermin; for I hate them perfectly, because they love fish so well, or rather, because they destroy so much; indeed so much that, in my judgment, all men that keep Otter-dogs ought to have pensions from the king, to encourage them to destroy 
the very breed' of those base Otters, they do so much mischief.

Ven. But what say you to the Foxes of the Nation, would not you as willingly have them destroyed? for doubtless they do as much mischief as Otters do.

PIsc. Oh, Sir, if they do, it is not so much to me and my fraternity, as those base vermin the Otters do.

Auc. Why, Sir, I pray, of what fraternity are you, that you are so angry with the poor Otters?

Pisc. I am, Sir, a brother of the Angle, and therefore an enemy to the Otter:* for you are to note, that we Anglers all love one another, and therefore do I hate the Otter, both for my own and for their sakes who are of my brotherhood.

VEN. And I am a lover of Hounds; I have followed many a pack of dogs many a mile, and heard many merry huntsmen make sport and scoff at Anglers.

Auc. And I profess myself a Falconer, and have heard many grave serious men pity them, it is such a heavy, contemptible, dull recreation.

PIsc. You know; gentlemen, it is an easy thing to scoff at any art or recreation; a little wit mixed with ill-nature, confidence, and malice, will do it ; but though they often venture boldly, yet they are often caught,

* The Otter has disappeared from the Lea, and is now rare in all the rivers of the Metropolitan counties. This amphibious animal is destructive to trout and small river fish; but, strange as it may appear, he proves the conservator of salmon, by destroying trout, the worst enemies of that fish. The Otter cannot, in open water, catch the salmon; who is too fleet for him; but he sometimes captures that fish in shallow and confined water, more by stratagem than speed. Trout the Otter can run down. He kills them in large numbers, to the delight of the owners of salmon rivers. When salmon are in the act of spawning, they are surrounded by trout, hungering after the ova, the greater portion of which they, would devour were they not beaten off by one or other of the breeding salmon. Trout, moreover, feed voraciously on salmon-fry, so that by destroying them the Otter does good service to salmon-fishing. -E. 
even in their own trap, according to that of Lucian, the father of the family of scoffers.

Lucian, well skill'd in scoffing, this hath writ,

Friend, that's your folly, which you think your wit ; This, you vent oft, void both of wit and fear, Meaning another, when yourself you jeer.

If to this you add what Solomon says of scoffers, that " they are an abomination to mankind," let them that think fit scoff. on, and be a scoffer still; but I account them enemies to me and to all that love virtue and angling.

And for you that have heard many grave, serious men pity Anglers; let me tell you, Sir, there be many men that are by others taken to be serious and grave men, whom we contemn and pity. Men that are taken to be grave, because nature hath made them of a sour complexion; money-getting men, men that spend all their time, first in getting, and next in anxious care to keep it ; men that are condemned to be rich, and then always busy or discontented; for these poor rich men, we Anglers pity them perfectly, and stand in no need to borrow their thoughts to think ourselves so happy. No, no, Sir, we enjoy a contentedness above the reach of such dispositions, and as the learned and ingenuous Montaigne says-like himself, freely, "When my cat and I entertain each other with mutual apish tricks, as playing with a garter, who knows but that I make my cat more sport than she makes me? Shall I conclude her to be simple, that has her time to begin or refuse to play as freely as I myself have? Nay, who knows but that it is a defect of my not understanding her language (for doubtless cats talk and reason with one another), that we agree no better? And who knows but that she pities me for being no wiser, than to play with her, and-laughs and censures my folly for making sport for her, when we two play together?" 
Thus freely speaks Montaigne concerning cats; and I hope I may take as great a liberty to blame any man, and laugh at him too, let him be never so grave, that hath not heard what Anglers can say in the justification of their art and recreation; which I may again tell you is so full of pleasure, that we need not borrow their thoughts to make ourselves liappy.

VEN. Sir, you have almost amazed me; for though I am no scoffer, yet I have, I pray let me speak it without offence, always looked upon Anglers as more patient and more simple men, than I fear I shall find you to be.

PIsc. Sir, I hope you will not judge my earnestness to be impatience: and for my simplicity, if by that you mean a harmlessness, or that simplicity which was usually found in the primitive Christians, who were, as most Anglers are, quiet men, and followers of peace; men that were so simply wise, as not to seli their consciences to buy riches, and with them vexation and a fear to die; if you mean such simple men as lived in those times when there were fewer lawyers; when men might have had a lordship safely conveyed to them in a piece of parchment no bigger than your hand, though several sheets will not do it safely in this wiser age; I say, Sir, if you take us Anglers to be such simple men as I have spoken, then myself and those of my profession will be glad to be so understood: But if by simplicity you meant to express a general defect in those that profess and practise the excellent art of angling, I hope in time to disabuse you, and make the contrary appear so evidently that, if you will but have patience to hear me, I shall remove all the anticipations that discourse, or time, or prejudice, have possessed you with against that laudable and ancient art; for I know it worthy the knowledge and practice of a wise man.

But, gentlemen, though I be able to do this, I am not so unmannerly as to engross all the discourse to myself ; 
and, therefore, you two having declared yourselves, the one to be a lover of hawks, the other of hounds, I shall be most glad to hear what you can say in the commendation of that recreation which each of you love and practise; and having heard what you can say, I shall be glad to exercise your attention with what I can say concerning my own recreation and art of angling, and by this means we shall make the way to seem the shorter; and if you like my motion, I would have Mr. Falconer to begin.

Auc. Your motion is consented to with all my heart; and to testify it, I will begin as you have desired me.

And first, for the element that I use to trade in, which is the air, an element of more worth than weightan element that doubtless exceeds both the earth and water; for though I sometimes deal in both, yet the air is most properly mine; I and my hawks use that most, and it yields us most recreation: it stops not the high soaring of my noble, generous falcon; in it she ascends to such a height as the dull eyes of beasts and fish are not able to reach to ; their bodies are too gross for such high elevations: in the air my troops of hawks soar up on high, and when they are lost in the sight of men, then they attend upon and converse with the gods; therefore I think my eagle is so justly styled "Jove's servant in ordinary": and that very falcon, that I am now going to see, deserves no meaner a title, for she usually in her flight endangers herself, like the son of Dædalus, to have her wings scorched by the sun's heat, she flies so near it; but her mettle makes her careless of danger ; for then she heeds nothing, but makes her nimble pinions cut the fluid air, and so makes her highway over the steepest mountains and deepest rivers, and in her glorious career looks with contempt upon those high steeples and magnificent palaces which we adore and wonder at; from which height I can make'her to descend by 
a word from my mouth (which she both knows and obeys), to accept of meat from my hand, to own me for her master, to go home with me, and be willing the next day to afford me the like recreation.

And more : this element of air which I profess to trade in, the worth of it is such, and it is of such necessity, that no creature whatsoever, not only those numerous creatures that feed on the face of the earth, but those various creatures that have their dwelling within the waters, every creature that hath life in its nostrils stands in need of my element. The waters cannot preserve the fish without air, witness the not breaking of ice in an extreme frost : * the reason is, for that if the inspiring and expiring organ of any animal be stopped, it suddenly yields to nature and dies. Thus necessary is air to the existence both of fish and beasts, nay, even to man himself; that air or breath of life with which God at first inspired mankind, he, if he wants it, dies presently, becomes a sad object to all that loved and beheld him, and in an instant turns to putrefaction.

Nay more, the very birds of the air, those that be not hawks, are both as many and so useful and pleasant to mankind, that I must not let them pass without some observations. They both feed and refresh them-feed him with their choice bodies, and refresh him with their heavenly voices. I will not undertake to mention the several kinds of fowl by which this is done-and his curious palate pleased by day, and which with their very excrements afford him a soft lodging at nightthese I will pass by ; but not those little nimble musicians of the air, that warble forth their curious ditties, with

* Though deep waters may be frozen over, fish will live in them beneath the ice. In shallow waters fish are frequently frozen to death. Fish, like certain quadrupeds - the northern bear, the marmot, and the little dormouse, frequently remain in a torpid state during winter, and only revive with renewed increase of temperature of the water, caused by rains or atmospheric influence.-E. 
which nature hath furnished them to the shame of art.

As first the lark, when she means to rejoice, to cheer herself and those that hear her; she then quits the earth, and sings as she ascends higher into the air, and having ended her heavenly employment, grows then mute and sad, to think she must descend to the dull earth, which she would not touch, but for necessity.

How do the blackbird and thrassel [thrush] with their melodious voices bid welcome to the cheerful spring, and in their fixed months warble forth such ditties as no art or instrument can reach to !

Nay, the smaller birds also do the like in their particular seasons, as namely the leverock, the titlark, the little linnet, and the honest robin, that loves mankind both alive and dead.

But the nightingale, another of my airy creatures, breathes such sweet loud music out of her little instrumental throat, that it might make mankind to think miracles are not ceased. He that at midnight, when the very labourer sleeps securely, should hear, as I have very often, the clear airs, the sweet descants, the natural rising and falling, the doubling and redoubling of her voice, might well be lifted above earth, and say, "Lord, what music hast thou provided for the saints in heaven, when thou affordest bad men such music on earth ?"

And this makes me the less to wonder at the many aviaries in Italy, or at the great charge of Varro's aviary, the ruins of which are yet to be seen in Rome, and is still so famous there, that it is reckoned for one of those notables which men of foreign nations either record, or lay up in their memories, when they return from travel.

This for the birds of pleasure, of which very much more might be said. My next shall be of birds of political 
use. I think 'tis not to be doubted that swallows * have been taught to carry letters between two armies. But it is certain, that when the Turks besieged Malta or Rhodes (I now remember not which it was), pigeons are then related to carry and recarry letters. And Mr. G. Sandys, in his Travels, relates it to be done between Aleppo and Babylon. But if that be disbelieved, it is not to be doubted that the dove was sent out of the ark by Noah, to give him notice of land, when to him all appeared to be sea; and the dove proved a faithful and comfortable messenger. And for the sacrifices of the law, a pair of turtle-doves or young pigeons were as well accepted as costly bulls and rams. And when God would feed the prophet Elijah after a kind of miraculous manner, He did it by ravens, who brought him meat morning and evening. Lastly, the Holy Ghost, when $\mathrm{He}$ descended visibly upon our Saviour, did it by assuming the shape of a dove. And to conclude this part of my discourse, pray remember these wonders were done by birds of the air, the element in which they and I take so much pleasure.

There is also a little contemptible winged creature, an inhabitant of my aërial element, namely, the laborious bee, of whose prudence, policy, and regular government of their own commonwealth, I might say much, as also of their several kinds, and how useful their honey and wax are both for meat and medicines to mankind; but I will leave them to their sweet labour, without the least disturbance, believing them to be all very busy at this very time amongst the herbs and flowers that we see nature puts forth this May morning.

* Walton's knowledge of Natural History was superficial and superstitious. No birds can be trained to fly to and from places. The carrier-pigeon will only fly with a message, generally written on a slip of oiled tissue-paper lapped round the leg, from a place to which the bird is taken, to its home. It will not carry a message from its home or dove-cote to a given place; it can make a return voyage, but not an outward one.-E. 
And now to return to my hawks, from whom I have made. too long a digression; you are to note, that they are usually distinguished into two kinds; namely, the long-winged and the short-winged hawk: of the first kind, there be chiefly in use amongst us in this nation,

The Gerfalcon and Jerkin,

The Falcon and Tassel-gentel,

The Laner and Lanaret,

The Bockerel and Bockeret,

The Saker and Sacaret,

The Merlin and Jack Merlin,

The Hobby and Jack :

There is the Stelletto of Spain,

The Blood-red Rook from Turkey,

The Waskite from Virginia :

And there is of short-winged hawks,

The Eagle and Iron,

The Goshawk and Tarcel,

The Sparhawk and Musket,

The French Pye, of two sorts.

These are reckoned hawks of note and worth; but we have also hawks of an inferior rank,

The Stanyel, the Ringtail,

The Raven, the Buzzard,

The Forked Kite, the Bald Buzzard,

The Hen-driver, and others that I forbear to name.*

* It is evident, from this list of so-called falcons, that Walton's "Auceps" was not an adept in the art of hawking. The blood-red rook, the French pye, and the raven are not falcons at all, and were never trained to fly at winged game. Of the other birds named in the list, only three are used in hawking, viz., the gerfalcon, the goshawk, and the falcon and tassel-gentel. It may be necessary to explain the last two names. By "falcon" is meant the peregrine falcon, the best of all the tribe ; and "tassel-gentel " is merely the peregrine in its second or third year. The merlin and hobby are very small hawks, and will catch quails, larks, and sometimes partridges. The same may be said of the sparrow-hawk. The eagle, buzzard, hen-driver (now called hen-harrier), and kite, were never valued in hawking. In fact, these latter birds do not pursue their quarry, but pounce upon it.-E. 
Gentlemen, if I should enlarge my discourse to the observation of the eires, the brancher, the ramish hawk, the haggard, and the two sorts of lentners, and then treat of their several ayries, their mewings, rare order of casting, and the renovation of their feathers : their reclaiming, dieting, and then come to their rare stories of practice; I say, if I should enter into these, and many other observations that I could make, it would be much, very much pleasure to me : but lest I should break the rules of civility to you, by taking up more than the proportion of time allotted to me, I will here break off, and entreat you, Mr. Venator, to say what you are able in the commendation of hunting, to which you are so much affected; and, if time will serve, I will beg your favour for a further enlargement of some of those several heads of which I have spoken. But no more at present.

VEN. Well, Sir, and I will now take my turn, and will first begin with a commendation of the Earth, as you have done most excellently of the Air; the earth being that element upon which I drive my pleasant, wholesome, hungry trade. The earth is a solid, settled element : an element most universally beneficial both to man and beast: to men who have their several recreations upon it, as horse-races, hunting, sweet smells, pleasant walks : the earth feeds man, and all those several beasts that both feed him, and afford him recreation. What pleasure doth man take in hunting the stately stag, the generous buck, the wild boar, the cunning otter, the crafty fox, and the fearful hare? And if I may descend to a lower game, what pleasure is it sometimes with gins to betray the very vermin of the earth! as namely, the fitchet, the fulimart, the ferret, the pole-cat, the mould-warp, and the like creatures that live upon the face and within the bowels of the earth! How doth the earth bring forth herbs, flowers, and fruits, both for physic and the pleasure of mankind! and 
above all, to me at least, the fruitful vine, of which, when I drink moderately, it clears my brain, cheers my heart, and sharpens my wit. How could Cleopatra have feasted Mark Antony with eight wild boars roasted whole at one supper, and other meat suitable, if the earth had not been a bountiful mother? But to pass by the mighty elephant, which the earth breeds and nourisheth, and descend to the least of creatures, how doth the earth afford us a doctrinal example in the little pismire, who in the summer provides and lays up her winter provision, and teaches man to do the like! The earth feeds and carries those horses that carry us. If I would be prodigal of my time and your patience, what might not I say in commendations of the earth? that puts limits to the proud and raging sea, and by that means preserves both man and beast, that it destroys them not, as we see it daily doth those that venture upon the sea, and are there shipwrecked, drowned, and left to feed haddocks; when we that are so wise as to keep ourselves on the earth, walk, and talk, and live, and eat, and drink, and go a hunting: of which recreation I will say a little, and then leave Mr. Piscator to the commendation of angling.

Hunting is a game for princes and noble persons; it hath been highly prized in all ages; it was one of the qualifications that Xenophon bestowed on his Cyrus, that he was a hunter of wild beasts.* Hunting trains up the younger nobility to the use of manly exercises in their riper age. $\dagger$ What more manly exercise than

- See Cyropædia, education of Cyrus, book i. chap. 5. Cyrus, when a boy, paid a visit to his maternal grandfather, Astyages, king of the Medes, who kept all sorts of wild beasts in large parks (paradeisoi, or paradises). Here the young Persian prince hunted continually the lion, the bear, and wild boar, and in the sporting-field prepared himself for the battle-field.-E.

$\dagger$ Professor John Wilson (the well-known Kit North of Blackwood) attributes the excellency of our cavalry officers to their foxhunting education. The Duke of Wellington kept a pack of fox- 
hunting the wild boar, the stag, the buck, the fox, or the hare? How doth it preserve health, and increase strength and activity!

And for the dogs that we use, who can commend their excellency to that height which they deserve? How perfect is the hound at smelling, who never leaves or forsakes his first scent, but follows it through so many changes and varieties of other scents, even over and in the water, and into the earth! What music doth a pack of dogs then make to any man, whose heart and ears are so happy as to be set to the tune of such instruments! How will a right greyhound fix his eye on the best buck in a herd, single him out, and follow him, and him only, through a whole herd of rascal game, and still know and then kill him! For my hounds, I know the language of them, and they know the language and meaning of one another as perfectly as we know the voices of those with whom we discourse daily.

I might enlarge myself in the commendation of hunting, and of the noble hound especially, as also of the docibleness of dogs in general ; and I might make many observations of land creatures, that for composition, order, figure, and constitution, approach nearest to the completeness and understanding of man; especially of those creatures, which Moses in the Law permitted to the Jews, which have cloven hoofs, and chew the cud; which I shall forbear to name, because I will not be so uncivil to Mr. Piscator, as not to allow him a time for the commendation of angling, which he calls an art; but doubtless it is an easy one ; and, Mr. Auceps, I doubt we shall hear a watery discourse of it, but I hope it will not be a long one.

Auc. And I hope so too, though I fear it will.

Pisc. Gentlemen, let not prejudice prepossess you. I

hounds in Spain, and hunted when his troops were in their winter cantonments. $-\mathrm{E}$. 
confess my discourse is like to prove suitable to my recreation, calm, and quiet; we seldom take the name of God into our mouths but it is either to praise him or pray to him; if others use it vainly in the midst of their recreations, so vainly as if they meant to conjure, I must tell you that it is neither our fault nor our custom; we protest against it. But pray remember, I accuse nobody; for as I would not make a "watery discourse," so I would not put too much vinegar into it, nor would I raise the reputation of my own art by the diminution or ruin of another's. And so much for the prologue to what I mean to say.

And now for the water, the element that I trade in. The water is the eldest daughter of the creation, the element upon which the Spirit of God did first move, the element which God commanded to bring forth living creatures abundantly; and without which, those that inhabit the land, even all creatures that have breath in their nostrils, must suddenly return to putrefaction. Moses, the great law-giver, and chief philosopher, skilled in all the learning of the Egyptians, who was called the friend of God, and knew the mind of the Almighty, names this element the first in the creation; this is the element upon which the Spirit of God did first move, and is the chief ingredient in the creation: many philosophers have made it to comprehend all the other elements, and most allow it the chiefest in the mixtion of all living creatures.

There be that profess to believe that all bodies are made of water, and may be reduced back again to water only: they endeavour to demonstrate it thus :

Take a willow, or any like speedy growing plant, newly rooted in a box or barrel full of earth, weigh them all together exactly when the tree begins to grow, and then weigh all together after the tree is increased from its first rooting, to weigh a hundred pound weight more 
than when it was first rooted and weighed; and you shall find this augment of the tree to be without the diminution of one drachm weight of the earth. Hence they infer this increase of wood to be from water of rain, or from dew, and not to be from any other element. And they affirm they can reduce this wood back again to water; and they affirm also the same may be done in any animal or vegetable. And this I take to be a fair testimony of the excellency of my element of water.

The water is more productive than the earth. Nay, the earth hath no fruitfulness without showers or dews; for all the herbs and flowers and fruit are produced, and thrive by the water; and the very minerals are fed by streams that run under ground, whose natural course carries them to the tops of many high mountains, as we see by several springs breaking forth on the tops of the highest hills; and this is also witnessed by the daily trial and testimony of several miners.

Nay, the increase of those creatures that are bred and fed in the water is not only more and more miraculous, but more advantageous to man, not only for the lengthening of his life, but for preventing of sickness ; for it is observed by the most learned physicians, that the casting off of Lent and other fish days, which hath not only given the lie to so many learned, pious, wise founders of colleges, for which we should be ashamed, hath doubtless been the chief cause of those many putrid, shaking, intermitting agues, unto which this nation of ours is now more subject than those wiser countries that feed on herbs, sallads, and plenty of fish ; of which it is observed in story, that the greatest part of the world now do. And it may be fit to remember that Moses appointed fish to be the chief diet for the best commonwealth that ever yet was.*

" Moses did not appoint fish to be the " chief diet." He merely tells the members of the "best commonwealth" what fish it is 100-B 
And it is observable, not only that there are fish, as namely the whale, three times as big as the mighty elephant, that is so fierce in battle, but that the mightiest feasts have been of fish. The Romans in the height of their glory have made fish the mistress of all their entertainments; they have had music to usher in their sturgeons, lampreys, and mullets, which they would purchase at rates rather to be wondered at than believed. He that shall view the writings of Macrobius, or Varro, may be confirmed and informed of this, and of the incredible value of their fish and fish-ponds.

But, gentlemen, I have almost lost myself, which I confess I may easily do in this philosophical discourse; I met with most of it very lately, and I hope, happily, in a conference with a most learned physician, Dr. Wharton,* a dear friend; that loves both me and my art of angling. But, however, I. will wade no deeper in these mysterious arguments, but pass to such observations as I can manage with more pleasure, and less fear of running into error. But I must not yet forsake the waters, by whose help we have so many known advantages.

lawful for them to eat, and what fish they should not touch. In respect to flesh-meat he does the same. Leviticus xi. 9, 10, Moses orders, "These shall ye eat of all that are in the waters : whatsoever hath fins and scales in the waters, in the seas, and in the rivers, them shall ye eat. And all that have not fins and scales in the seas, and in the rivers, of all that move in the waters, and of any living thing which is in the waters, they shall be an abomination unto you. In Deut. xiv. 9, 10, the great law-giver repeats his fish-eating clauses: "These ye shall eat of all that are in the waters: all that liave fins and scales shall ye eat : and whatsoever hath not fins and scales ye may not eat; it is unclean unto you." The modern Hebrews heed very little the edible interdicts of their progenitors. They are, in England at least, great consumers and the very best cooks of fish without scales - of plaice, soles, turbot, cod, barbel, tench, etc. If the sumptuary laws of Moses were observed by them, the economic luxuries of the fried-flsh shops would be lost to myriads of Jews and Gentiles.-E.

* Dr. Thomas Wharton, an eminent physician and excellent anatomist, and Gresham professor of physic. He lived in Aldersgatestreet, London, and died 1673. 
And first to pass by the miraculous cures of our known baths, how advantageous is the sea for our daily traffic, without which we could not now subsist! How does it not only furnish us with food and physic for the bodies, but with such observations for the mind as ingenious persons would not want!

How ignorant had we been of the beauty of Florence, of the monuments, urns, and rarities that yet remain in and near unto old and new Rome, so many as it is said will take up a year's time to view, and afford to each of them but a convenient consideration! And therefore it is not to be wondered at, that so learned and devout a father as St. Jerome, after his wish to have seen Christ in the flesh, and to have heard St. Paul preach, makes his third wish, to have seen Rome in her glory; and that glory is not yet all lost, for what pleasure is it to see the monuments of Livy, the choicest of the historians; of Tully, the best of orators; and to see the bay trees that now grow out of the very tomb of Virgil! These, to any that love learning, must be pleasing. But what pleasure is it to a devout Christian to see there the humble house in which St. Paul was content to dwell, and to view the many rich statues that are made in honour of his memory! nay, to see the very place in which St. Peter* and he lie buried together! These are in and near to Rome. And how much more doth it please the pious curiosity of a Christian to see that place on which the blessed Saviour of the world was pleased to humble Himself, and to take our nature upon Him, and to converse with men: to

* The Protestants deny not only that St. Peter lies buried in the Vatican, as the Romish writers assert, but that he ever was at Rome. See the Historia A postolica of Lud. Capellus. The sense of the Protestants on this point is expressed in the following epigram, alluding to the prænomen of Peter, Simon, and to the simony practised in that city-

"An Petrus fuerat Romæ sub judice lis est, Simonem Romæ nemo fuisse negat."-H. 
see Mount Sion, Jerusalem, and the very sepulchre of our Lord Jesus? How may it beget and heighten the zeal of a Christian to see the devotions that are daily paid to him at that place? Gentlemen, lest I forget myself, I will stop here and remember you, that but for my element of water, the inhabitants of this poor island must remain ignorant that such things ever. were, or that any of them have yet a being.

Gentlemen, I might both enlarge and lose myself in such like arguments; I might tell you that Almighty God is said to have spoken to a fish but never to a beast ; that $\mathrm{He}$ hath made a whale a ship to carry, and set His prophet Jonah safe on the appointed shore. Of these I might speak, but I must in manners break off, for I see Theobald's house. I cry your mercy for being so long, and thank you for your patience.

Auc. Sir, my pardon is easily granted you : I except against nothing that you have said; nevertheless I must part with you at this park-wall, for which I am very sorry; but I assure you, Mr. Piscator, I now part with you full of good thoughts, not only of yourself, but your recreation. And so, gentlemen, God keep you both.

Pisc. Well now, Mr. Venator, you shall neither want time, nor my attention to hear you enlarge your discourse concerning hunting.

VEN. Not I, sir: I remember you said that angling itself was of great antiquity and a perfect art, and an art not easily attained to; and you have so won upon me in your former discourse, that I am very desirous to hear what you can say farther concerning those particulars.

Pisc. Sir, I did say so: and.I doubt not but if you and I did converse together but a few hours, to leave you possessed with the same high and happy thoughts that now possess me of it; not only of the antiquity of angling, but that it deserves commendations; and 
that it is an art, and an art worthy the knowledge and practice of a wise man.

Ven. Pray, sir, speak of them what you think fit, for we have yet five miles to the Thatched House ; during which walk, I dare promise you my patience and diligent attention shall not be wanting. And if you shall make that to appear which you have undertaken-first, that it is an art, and an art worth the learning, I shall beg that I may attend you a day or two a-fishing, and that I may become your scholar and be instructed in the art itself which you so much magnify.

PISc. $O$, sir, doubt not that angling is an art; is it not an art to deceive a trout with an artificial fly ? a trout! that is more sharp-sighted than any hawk you have named, and more watchful and timorous than your high mettled merlin is bold; * and yet I doubt not to catch a brace or two to-morrow for a friend's breakfast; doubt not, therefore, Sir, but that angling is an art, and an art worth your learning. The question is rather, whether you be capable of learning it ? for angling is somewhat like poetry, men are to be born so : I mean, with inclinations to it, though both may be heightened by discourse and practice : but he that hopes to be a good angler, must not only bring an inquiring, searching, observing wit, but he must bring a large measure of hope and patience, and a love and propensity to the art itself ; but having once got and practised it, then doubt not but angling will prove to be so pleasant, that it will prove to be like virtue, a reward to itself.

VEN. Sir, I am now become so full of expectation, that I long much to have you proceed; and in the order you propose.

PISc. Then first, for the antiquity of angling, of which

* Walton is evidently thinking of AucEPs, the falconer so named, who parted company as they neared Theobald's House, otherwise he would not have said to Venator, the hunter with hounds and not with hawks, "your merlin." It may be taken in another sense.-E. 
I shall not say much, but only this; some say it is as ancient as Deucalion's flood : 'others, that Belus, who was the first inventor of godly and virtuous recreations, was the first inventor of angling; and some others say, for former times have had their disquisitions about the antiquity of it, that Seth, one of the sons of Adam, taught it to his sons, and that by them it was derived to posterity : others say, that he left it engraven on those pillars which he erected, and trusted to preserve the knowledge of the mathematics, music, and the rest of that precious knowledge and those useful arts which by God's appointment or allowance and his noble industry, were thereby preserved from perishing in Noah's flood.*

These, Sir, have been the opinions of several men that have possibly endeavoured to make angling more ancient than is needful, or may well be warranted; but for my part, I shall content myself in telling you, that angling is much more ancient than the Incarnation of our Saviour ; for in the prophet Amos $\uparrow$ mention is made of fish-hooks ; and in the book of Job, which was long before the days of Amos, for that book is said to be writ by Moses, mention

* Those that say this are very safe in their assertion, for there is no remaining evidence to contradict it. It may, however, be observed, that the same has been said in favour of many other arts ; and, if I mistake not, of the hermetic science and freemasonry: concerning the former whereof Ashmole has the confidence to affirm, that by means of it Adam and the fathers before the flood, as also Abraham, Moses, and Solomon, wrought many wonders. See the Prolegomena to his Theatrum Chemicum Britannicum, in which there is more such nonsense and absurdity. $-\mathrm{H}$.

$\dagger$ In the book of Amos, iv. 2, we find- "The Lord God hath sworn by His holiness, that, lo, the days shall come upon you, that He will take you away with hooks, and your posterity with fishhooks." In Jeremiah xvi. 16 are these words : "Behold, I will send for many fishers, saith the Lord, and they shall fish them; and after will I send for many hunters, and they shall hunt them from every mountain, and from every hill, and out of the holes of the rocks." Finally, in Habakkuk i. 15 it is written: "They take up all of them with the angle, they catch them in their net, and gather them in their drag," etc. Angling and hunting are unquestionably the most primitive of field sports. Necessity as well as plcasure led to the pursuit of bird, beast, and fish.-E. 
is made also of fish-hooks, which must imply anglers in those times.

But, my worthy friend, as I would rather prove myself a gentleman, by being learned and humble, valiant and inoffensive, virtuous and communicable, than by any fond ostentation of riches; or, wanting those virtues myself, boast that these were in my ancestors (and yet I grant that where a noble and ancient descent, and such merit meet in any man, it is a double dignification of that person); so if this antiquity of angling, which for my part I have not forced, shall, like an ancient family, be either an honour or an ornament to this virtuous art which I profess to love and practise, I shall be the gladder that I made an accidental mention of the antiquity of it, of which I shall say no more, but proceed to that just commendation which I think it deserves.

And for that, I shall tell you, that in ancient times a debate hath arisen, and it remains yet unresolved: whether the happiness of man in this world, doth consist more in contemplation or action?

Concerning which, some have endeavoured to maintain their opinion of the first; by saying, that the nearer we mortals come to God by way of imitation, the more happy we are. And they say that God enjoys Himself only, by a contemplation of His own infiniteness, eternity, power, and goodness, and the like. And upon this ground, many cloisteral men of great learning and devotion, prefer contemplation before action. And many of the fathers seem to approve this opinion, as may appear in their commentaries upon the words of our Saviour to Martha (Luke x. 41, 42).

And on the contrary, there want not men of equal authority and credit, that prefer action to be the more excellent; as namely, experiments in physic, and the application of it, both for the ease and prolongation of man's life; by which each man is enabled to act and do 
good to others, either to serve his country, or do good to particular persons. And they say also, that action is doctrinal, and teaches both art and virtue, and is a maintainer of human society; and for these, and other like reasons, to be preferred before contemplation.

Concerning which two opinions, I shall forbear to add a third, by declaring my own ; and rest myself contented in telling you, my very worthy friend, that both these meet together, and do most properly belong to the most honest, ingenious, quiet, and harmless art of angling.

And first, I shall tell you what some have observed, and I have found it to be a real truth, that the very sitting by the river's side is not only the quietest and fittest place for contemplation, but will invite an angler to it: and this seems to be maintained by the learned Peter Du Moulin,* who in his discourse of the fulfilling of prophecies, observes, that when God intended to reveal any future events or high notions to His prophets, He then carried them either to the deserts or the sea-shore, that laving so separated them from amidst the press of people and business, and the cares of the world, He might settle their mind in a quiet repose, and there make them fit for revelation.

And this seems also to be intimated by the Children of Israel (Psal. cxxxvii.), $\dagger$ who having in a sad condition banished all mirth and music from their pensive hearts, and having hung up their then mute harps upon the willow-trees growing by the rivers of Babylon, sat down upon these banks bemoaning the ruins of Sion, and contemplating their own sad condition.

And an ingenious Spaniard says, that " rivers and the inhabitants of the watery element were made for wise

* An ancient prebendary of Canterbury, and author of several pieces in the Romish controversy.-H.

$\dagger$ " By the rivers of Babylon, there we sat down, yea, we wept, when we remembered Zion. We hanged our harps upon the willows in the midst thereof" (Psalm cxxxvii. 1, 2). 
men to contemplate, and fools to pass by without consideration." And though I will not rank myself in the number of the first, yet give me leave to free myself from the last, by offering to you a short contemplation, first of rivers and then of fish; concerning which I doubt not but to give you many observations that will appear very considerable: I am sure they have appeared so to me, and made many an hour to pass away more pleasantly, as I have sat quietly on a flowery bank by a calm river, and contemplated what I shall now relate to you.

And first, concerning rivers : there be so many wonders reported and written of them, and of the several creatures that be bred and live in them; and those by authors of so good credit, that we need not to deny them an historical faith.

As namely of a river in Epirus, that puts out any lighted torch, and kindles any torch that was not lighted. Some waters being drank cause madness, some drunkenness, and some laughter to death. The River Selarus in a few hours turns a rod or wand to stone; and our Camden mentions the like in England, and the like in Lochmere in Ireland. There is also a river in Arabia, of which all the sheep that drink thereof have their wool turned into a vermilion colour. And one of no less credit than Aristotle, tells us of a merry river, the River Elusina, that dances at the noise of music, for with music it bubbles, dances, and grows sandy, and so continues till the music ceases, but then it presently returns to its wonted calmness and clearness. And Camden tells us of a well near to Kirby in Westmoreland, that ebbs and flows several times every day: and he tells us of a river in Surrey, it is called Mole, that after it has run several miles, being opposed by hills, finds or makes itself a way under ground, and breaks out again so far off, that the inhabitants thereabout boast, as the Spaniards do of their River Anus, that they feed divers flocks of sheep upon a bridge. 
And lastly, for I would not tire your patience, one of no less authority than Josephus, that learned Jew, tells us of a river in Judea that runs swiftly all the six days of the week, and stands still and rests all their Sabbath.

But I will lay aside my discourse of rivers, and tell you some things of the monsters, or fish, call them what you will, that they breed and feed in them. Pliny, the philosopher says, in the third chapter of his ninth book, that in the Indian Sea, the fish called baloena or whirlpool, is so long and broad as to take up more in length and breadth than two acres of ground; and, of other fish of two hundred cubits long; and that, in the River Ganges, there be eels of thirty feet long. He says there, that these monsters appear in the sea only when tempestuous winds oppose the torrents of waters falling from the rocks into it, and so turning what lay at the bottom to be seen on the water's top. And he says, that the people of Cadara, an island near this place, make the timber for their houses of those fish-bones. He there tells us, that there are sometimes a thousand of these great eels found wrapt or interwoven together. He tells us there, that it appears that dolphins love music, and will come when called for, by some men or boys that know, and use to feed them; and that they can swim as swift as an arrow can be shot out of a bow; and much of this is spoken concerning the dolphin, and other fish, as may be found also in the learned Dr. Casaubon's Discourse of Credulity and Incredulity, printed by him about the year 1670 .

I know, we islanders are averse to the belief of these wonders; but there be so many strange creatures to be now seen, many collected by John Tradescant,* and others

* There were, it seems, three of the Tradescants-grandfather, father, and son; the son is the person here meant; the two former were gardeners to Queen Elizabeth, and the latter to King Charles I. They were all great botanists, and collectors of natural and other curiosities, and dwelt at South Lambeth in Surrey; and, dying there, were buried in Lambeth churchyard. Mr. Ashmole con- 
added by my friend Elias Ashmole, Esq., who now keeps them carefully and methodically at his house near to Lambeth near London, as may get some belief of some of the other wonders I mentioned. I will tell you some of the wonders that you may now see, and not till then believe, unless you think fit.

You may see the hog-fish, the dog-fish, the dolphin, the coney-fish, the parrot-fish, the shark, the poison-fish, sword-fish, and not only other incredible fish, but you may there see the salamander, several sorts of barnacles, and Solan geese, the bird of Paradise, such sorts of snakes, and such bird's-nests, and of so various forms, and so wonderfully made, as may beget wonder and amusement in any beholder : and so many hundred of other rarities in that collection, as will make the other wonders I spake of, the less incredible ; for you may note, that the waters are nature's store-house, in which she locks up her wonders.

But, Sir, lest this discourse may seem tedious, I shall give it a sweet conclusion out of that holy poet Mr. George Herbert his divine "Contemplation on God's Providence."

Lord, who hath praise enough ; nay, who hath any ?

None can express Thy works, but he that knows them ; And none can know Thy works, they are so many,

And so complete, but only he that owes them.

tracted an acquaintance with the last of them, and together with his wife boarded at his house for a summer, during which Ashmole agreed for the purchase of Tradescant's collection, and the same was conveycd to him by a deed of gift from Tradescant and his wife. Tradescant soon after died, and Ashmole was obliged to file a bill in the Court of Chancery for the delivery of the curiosities, and succeeded in his suit. Mrs. Tradescant, shortly after the pronouncing the decree, was found drowned in her pond. This collection, with what additions he afterwards made to it, Mr. Ashmole gave to the University of Oxford, and so became the founder of the Ashmolean Muscum. A monument for all the three Tradescants, very curiously ornamented with seulptures, is to be seen in Lambetlı churcliyard. The Tradescants were the first collectors of natural curiosities in this kingdom, and Ashmole and Sir Hans Sloane were the second.-H. 
We all acknowledge both Thy power and love

To be exact, transcendent, and divine ;

Who dost so strongly and so sweetly move,

Whilst all things have their end, yet none but Thine.

Wherefore, most sacred Spirit, I here present,

For me, and all my fellows, praise to Thee;

And just it is that I should pay the rent,

Because the benefit accrues to me.

And as concerning fish, in that psalm (Psalm civ.), wherein, for height of poetry and wonders, the prophet David seems even to exceed himself; how doth he there express himself in choice metaphors, even to the amazement of a contemplative reader, concerning the sea, the rivers, and the fish therein contained! And the great naturalist, Pliny, says, " that nature's great and wonderful power is more demonstrated in the sea than on the land." And this may appear by the numerous and various creatures inhabiting both in and about that element; as to the readers of Gesner,* Rondeletius, $\uparrow$ Pliny, Ausonius, $\ddagger$ Aristotle, and others, may be demonstrated. But I will sweeten this discourse also out of a contemplation in divine Du Bartas, $\S$ (in the fifth day), who says :-

* Conrade Gesner, an eminent physician and naturalist, was born at Zurich, in 1516. His skill in botany and natural history was such as procurcd him the appellation of the Pliny of Germany; and Beza, who knew him, scruples not to assert, that he concentred In himself the learning of Pliny and Varro. He died in $\mathbf{1 5 6 5 .}$

$\dagger$ Guillaume Rondelet, an eminent physician, born at Montpelier, in Languedoc, 1507. He wrote several books, and a treatise De Piscibus Marinis, where all that Walton has taken from him is to be found. He died very poor, of a surfeit occasioned by eating of figs to excess, in 1566.

$\ddagger$ Decius Ausonius, a native of Bordeaux, was a Latin poet, consul of Rome, and preceptor to the Emperor Gratian. He died about 390.

§ Guillaume de Saluste, Sieur du Bartas, was a poet of great reputation in Walton's time. He wrote, in French, a poem called "Divine Weeks and Works," from whence the passage in the text and many others cited in this work are extracted. This, with his other delightful works, was translated into English by Joshua Sylvester. $-\mathrm{H}$. 
God quicken'd in the sea, and in the rivers, So many fishes of so many features, That in the waters we may see all creatures, Even all that on the earth are to be found, As if the world were in deep waters drown'd. For seas-as well as skies-have sun, moon, stars ; As well as air-swallows, rooks, and stares; As well as earth-vines, roses, nettles, melons, Mushrooms, pinks, gilliflowers, and many millions Of other plants, more rare, more strange than these, As very fishes, living in the seas ;

As also rams, calves, horses, hares, and hogs, Wolves, urchins, lions, elephants, and dogs ; Yea, men and maids; and, which I most admire, The mitred bishop and the cowled friar ; Of which, examples, but a few years since, Were shown the Norway and Polonian prince.

These seem to be wonders, but have had so many confirmations from men of learning and credit, that you need not doubt them; nor are the number, nor the various shapes of fishes, more strange or more fit for contemplation, than their different natures, inclinations and actions; concerning which I shall beg your patient ear a little longer.

The cuttle-fish will cast a long gut out of her throat, which, like as an angler doth his line, she sendeth forth and pulleth in again at her pleasure, according as she sees some little fish come near to her; and the cuttle-fish, being then hid in the gravel, lets the smaller fish nibble and bite the end of it, at which time she by little and little draws the smaller fish so near to her, that she may leap upon her, and then catches and devours her: and for this reason some have called this fish the sea-angler.

And there is a fish called a hermit, that at a certain age gets into a dead fish's shell, and like a hermit dwells there alone, studying the wind and weather, and so turns her shell, that she makes it defend her from the injuries that they would bring upon her.' 
There is also a fish called, by Ælian, in his 9 th book of Living Creatures, chap. 16, the Adonis, or darling of the sea; so called because it is a loving and innocent fish, a fish that hurts nothing that hath life, and is at peace with all the numerous inhabitants of that vast watery element : and truly I think most anglers are so disposed to most of mankind.

And there are also lustful and chaste fishes, of which I shall give you examples.

And first Du Bartas says of a fish called the sargus; which, because none can express it better than he does, I shall give you in his own words; supposing it shall not have the less credit for being in verse; for he hath gathered this and other observations out of authors that have been great and industrious searchers into the secrets of nature.

The adulterous sargus doth not only change

Wives every day, in the deep streams, but, strange !

As if the honey of sea-love delight

Could not suffice his raging appetite,

Goes courting she-goats on the grassy shore,

Horning their husbands that had horns before.

And the same author writes concerning the cantharus that which you shall also hear in his own words :-

But, contrary, the constant cantharus

Is ever constant to his faithful spouse ;

In nuptial duties spending his chaste life;

Never loves any but his own dear wife.

Sir, but a little longer, and I have done.

VEN. Sir, take what liberty you think fit, for your discourse seems to be music, and charms me to an attention.

Pisc. Why then, Sir, I will take a liberty to tell, or rather to remember you what is said of turtic-doves : first, that they silently plight their troth, and marry; and that then the survivor scorns, as the Thracian 
women are said to do, to outlive his or her mate, and this is taken for a truth; and if the survivor shall ever couple with another, then not only the living but the dead, be it either the he or the she, is denied the name and honour of a true turtle-dove.

And to parallel this land-rarity, and teach mankind moral faithfulness, and to condemn those that talk of religion, and yet come short of the moral faith of fish and fowl; men that violate the law affirmed by St. Paul, Rom. ii. 14, 15, to be writ in their hearts, and which he says shall at the last day condemn and leave them without excuse ; I pray hearken to what Du Bartas sings, for the hearing of such conjugal faithfulness will be music to all chaste ears, and therefore I pray hearken to what Du Bartas sings of the mullet.

But for chaste love the Mullet hath no peer ; For if the fisher hath surprised her pheer [mate], As mad with woe, to shore she followeth, Prest to consort him both in life and death.*

On the contrary, what shall I say of the house-cock, which treads any hen, and then, contrary to the swan, the partridge, and pigeon, takes no care to hatch, to feed, or to cherish his own brood, but is senseless, though they perish.

And it is considerable that the hen, which, because she also takes any cock, expects it not, who is sure the chickens be her own, hath by a moral impression her care and affection to her own brood more than doubled, even to such a height that our Saviour, in expressing his love to Jerusalem, Matt. xxiii. 37, quotes her for an example of tender affection; as His Father had done Job for a pattern of patience.

* All that Walton writes about the habits of fish, from the paragraph beginning, "The cuttle-fish," down to this point, has no foundation in fact. It deserves, however, the compliment paid to it by Venator-" Your discourse seems to be music, and charms me to an attention." $-\mathrm{E}$. 
And to parallel this cock, there be divers fishes that cast their spawn on flags or stones, and then leave it uncovered and exposed to become a prey and be devoured by vermin, or other fishes; but other fishes, as namely the barbel, take such care for the preservation of their seed, that unlike to the cock or the cuckoo, they naturally labour, both the spawner and the melter, to cover the spawn with sand or watch it,* or hide it in some secret place, unfrequented by vermin or any. fish but themselves.

Sir, these examples may to you and others seem strange, but they are testified, some by Aristotle, some by Pliny, some by Gesner, and by many others of credit ; and are believed and known by divers both of wisdom and experience, to be a truth; and indeed are, as I said at the beginning, fit for the contemplation of a most serious and a most pious man. And doubtless, this made the prophet David say, "They that occupy themselves in deep waters see the wonderful works of God;" indeed such wonders and pleasures too, as the land affords not.

And that they be fit for the contemplation of the most prudent and pious and peaceable men, seems to be testified by the practice of so many devout and contemplative men, as the patriarchs and prophets of old; and of the apostles of our Saviour in our latter times, of which twelve, we are sure He chose four that were simple fishermen, whom $\mathrm{He}$ inspired and sent to publish His blessed will to the Gentiles; and inspired them also with a power to speak all languages, and by their powerful eloquence to beget faith in the unbelieving Jews; and themselves to suffer for that Saviour whom their forefathers and they had crucified; and, in their sufferings, to preach freedom from the incumbrances of the law, and a new way to ever-

- No river-fish ever watches its spawn or ova after deposition. When the ovi are deposited by the female, and impregnated by the male fish, and covered in by a superstructure of any substance, they are abandoned by the parents, and left to be vivified by the chemical action of water, sun, and atmosphere.-E. 
lasting life: this was the employment of these happy fishermen. Concerning which choice, some have made these observations.

First, That He never reproved these for their employment or calling, as He did scribes and the money-changers. And secondly, He found that the hearts of such men by nature were fitted for contemplation and quietness ; men of mild, and sweet, and peaceable spirits, as indeed most anglers are: these men our blessed Saviour, who is observed to love to plant grace in good natures, though indeed nothing be too hard for Him; yet these men $\mathrm{He}$ chose to call from their irreprovable employment of fishing, and gave them grace to be His disciples, and to follow Him and do wonders. I say four of twelve.

And it is observable, that it was our Saviour's will, that these our four fishermen should have a priority of nomination in the catalogue of His twelve apostles, Matt. x. 2, Acts i. 13 ; as namely, first, St. Peter, St. Andrew, St. James, and St. John, and then the rest in their order.

And it is yet more observable, that when our blessed Saviour went up into the mount, when He left the rest of His disciples and chose only three to bear Him company at His Transfiguration, that those three were all fishermen. And it is to be believed, that all the other apostles, after they betook themselves to follow Christ, betook themselves to be fishermen too; for it is certain, that the greater number of them were found together fishing by Jesus after His Resurrection, as it is recorded in the 21 st chapter of St. John's Grospel ver. 3 and 4.

And since I have your promise to liear me with patience, I will take a liberty to look back upon an observation that hath been made by an ingenious and learned man, whio observes, that God hath been pleased to allow those, whom He Himself hath appointed to write His holy will in holy writ, yet, to express His will in such metaphors as their 
former affections or practice had inclined them to ; and he brings Solomon for an example, who before his conversion was remarkably carnally amorous ; and after, by God's appointment, wrote that spiritual dialogue, or holy amorous love-song, the Canticles, betwixt God and His church; in which he says, his beloved had eyes like the fish-pools of Heshbon.

And if this hold in reason, as I see none to the contrary, then it may be probably concluded, that Moses, who I told you before writ the book of Job, and the prophet Amos, who was a shepherd, were both anglers; for you shall, in all the Old Testament find fish-hooks, I think, but twice mentioned : namely, by meek Moses the friend of God, and by the humble prophet Amos. Concerning which last, namely the prophet Amos, I shall make but this observation; that he that shall read the humble, lowly, plain style of that prophet, and compare it with the high, glorious, eloquent style of the prophet Isaiah (though they both be equally true), may easily believe Amos to be, not only a shepherd, but a good-natured plain fisherman. Which I do the rather believe, by comparing the affectionate, loving, lowly, humble epistles of St. Peter, St. James, and St. John, whom we know were all fishers, with the glorious language and high metaphors of St. Paul, whom we may believe was not.

And for the lawfulness of fishing : it may very well be maintained by our Saviour's bidding St. Peter cast his hook into the water and catch a fish, for money to pay tribute to Cæsar.

And let me tell you, that angling is of high esteem and much use in other nations. He that reads the voyages of Ferdinand Mendez Pinto,* shall find, that there he declares to have found a king and several priests a-fishing.

* A traveller so noted for his mendacity, that to call any narrator of travels a "Mendez Pinto," is an insult.-E. 
And he that reads Plutarch shall find that angling was not contemptible in the days of Mark Antony and Cleopatra, and that they, in the midst of their wonderful glory, used angling as a principal recreation.* And let me tell you, that in the Scripture, angling is always taken in the best sense, and that though hunting may be sometimes so taken, yet it is but seldom to be so understood. And let me add this more, he that views the ancient ecclesiastical canons, shall find hunting to be forbidden to churchmen, as being a turbulent, toilsome, perplexing recreation; and shall find angling allowed to clergymen, as being a harmless recreation, a recreation that invites them to contemplation and quietness.

I might here enlarge myself by telling you, what com-

* I must here so far differ from my author, as to say, that if angling was not contemptible in the days of Mark Antony and Cleopatra, that illustrious prostitute endeavoured to make it so. The fact related by Plutarch is the following:-

"It would be very tedious and trifling to recount all his follies; but his fishing must not be forgot. He went out one day to angle with Cleopatra ; and being so unfortunate as to catch nothing in the presence of his mistress, he was very much vexed, and gave secret orders to the fishermen to dive under water, and put fishes that had been fresh taken upon his hook. After he had drawn up two or three, Cleopatra perceived the trick; she pretended, however, to be surprised at his good fortune and dexterity, told it to all her friends, and invited them to come and see him fish the next day. Accordingly, a very large company went out in the fishing-vessels ; and as soon as Antony had let down his line, she commanded one of her servants to be beforehand with Antony's, and, diving into the water, to fix upon his hook a salted fish, one of those which were brought from the Euxine Sea."

[Shakespeare, no doubt, read the above passage from Plutarch ; for in his play of Antony and Cleopatra we find the following verses :-

"Cleopatra.-Give me mine angle. We'll to the river; there, My music playing far off, I will betray

Tawny-finn'd fishes : my bended hook shall pierce

Their slimy jaws; and as I draw them up,

I'll think them every one an Antony,

And say, "Ah, ha ! you're caught."

Charmian.- "Twas merry, when

You wager'd on your angling; when your diver

Did hang a salt-fish on his hook, which he

With fervency drew up."

Act II., Scene 5.] 
mendations our learned Perkins bestows on angling : and how dear a lover, and great a practiser of it our learned Doctor Whittaker was, as indeed many others of great learning have been. But I will content myself with two memorable men, that lived near to our own time, whom I also take to have been ornaments to the art of angling.

The first, is Doctor Nowel, sometime Dean of the Cathedral Church of St. Paul's in London, where his monument stands yet undefaced: a man that in the reformation of Queen Elizabeth, not that of Henry VIII., was so noted for his meek spirit, deep learning, prudence, and piety, that the then Parliament and Convocation both, chose, enjoined, and trusted him to be the man to make a catechism for public use, such a one as should stand as a rule for faith and manners to their posterity. And the good old man, though he was very learned, yet knowing that God leads us not to Heaven by many nor by hard questions, like an honest angler, made that good, plain, unperplexed catechism, which is printed with our good old service-book.* I say, this good old man was a dear lover and constant practiser of angling, as any age can produce : and his custom was to spend, besides his fixed hours of prayer (those hours which, by command of the church, were enjoined the clergy, and voluntarily dedicated to devotion by many primitive Christians); I say, besides those hours, this good man was observed to spend a tenth part of his time in angling; and, also for I lave conversed with those which have conversed with him, to bestow a tenth part of his revenue, and usually all his fish, amongst the poor that inhabited near to those rivers in which it was caught; saying often, " that charity gave life to religion:" and at his return to his house, would praise God he had spent that day free from

* The Catechism bound up with the Book of Common Prayer, is not that compiled by Dr. Nowel. He drew up, at the request of Mr. Secretary Cecil (temp. Eliz.), a larger Catechism, which was sanctioned by Convocation, and not by Parliament, in 1.562 . 
worldly trouble; both harmlessly, and in a recreation that became a churchman. And this good man was well content, if not desirous, that posterity should know he was an angler; as may appear by his picture, now to be seen, and carefully kept, in Brazen-nose College; to which he was a liberal benefactor. In which picture he was drawn, leaning on a desk, with his Bible before him, and on one hand of him his lines, hooks, and other tackling lying in a round : and on his other hand are his angle-rods of several sorts : and by them this is written, "That he died 13 Feb. 1601, being aged 95 years, 44 of which, he had been Dean of St. Paul's Church ; and that his age had neither impaired his hearing, nor dimmed his eyes, nor weakened his memory, nor made any of the faculties of his mind weak or useless." 'Tis said, that angling and temperance* were great causes of these blessings, and I wish the like to all that imitate him, and love the memory of so good a man.

My next and last example, shall be that under-valuer of money, the late provost of Eton College, Sir Henry Wotton-a man with whom I have often fished and conversed, a man whose foreign employments in the service of this nation, and whose experience, learning, wit, and cheerfulness, made his company to be esteemed one of the delights of mankind: this man, whose very approbation of angling were sufficient to convince any modest censurer of it, this man was also a most dear lover, and a frequent practiser of the art of angling; of which he would say, "'Twas an employment for his idle time,

* It would appear, that though reputed temperate, he was by no means a teetotaller; for Sir J. Hawkins says, " that Fuller, in his Worthies (Lancashire, p. 115), has thought it worth recording of this pious and learned divine, and that in language so very quaint as to be but just intelligible, that he was accustomed to fish in the Thames ; and having one day left his bottle of ale in the grass, on the bank of the river, he found it some days after, no bottle, but a gun, such the sound at the opening thereof. And hence, with what degree of sagacity let the reader determine, he seems to derive the origin of bottled ale in England." 
which was then not idly spent:" for angling was, after tedious study, a rest to his mind, a cheerer of his spirits, a diverter of sadness, a calmer of unquiet thoughts, a moderator of passions, a procurer of contentedness:" and "that it begat habits of peace and patience in those that professed and practised it." Indeed, my friend, you will find angling to be like the virtue of humility, which has a calmness of spirit, and a world of other blessings attending upon it. Sir, this was the saying of that learned man.

And I do easily believe, that peace and patience, and a calm content, did cohabit in the cheerful heart of Sir Henry Wotton ; because I know that when he was beyond seventy years of age, he made this description of a part of the present pleasure that possessed him, as he sat quietly in a summer's evening, on a bank a-fishing. It is a description of the spring; which, because it glided as soft and sweetly from his pen, as that river does at this time, by which it was then made, I shall repeat it unto you :-

This day dame Nature seem'd in love ;

The lusty sap began to move ;

Fresh juice did stir th' embracing vines ;

And birds had drawn their valentines.

The jealous trout, that low did lie,

Rose at a well-dissembled fly ;

There stood my friend, with patient skill,

Attending of his trembling quill ;

Already were the eaves possess'd

With the swift pilgrim's daubèd nest ;

The groves already did rejoice

In Philomel's triumphing voice,

The showers were short, the weather mild,

The morning fresh, the evening smiled.

Joan takes her neat-rubbed pail, and now

She trips to milk the sand-red cow ;

Where, for some sturdy foot-ball swain,

Joan strokes a syllabub or twain.

The fields and gardens were beset

With tulips, crocus, violet ; 
And now, though late, the modest rose

Did more than half a blush disclose.

Thus all looks gay and full of cheer,

To welcome the new-liveried year.

These were the thoughts that then possessed the undisturbed mind of Sir Henry Wotton. Will you hear the wish of another angler, and the commendation of his happy life, which he also sings in verse; viz., Jo. Davors, Esq.

Let me live harmlessly; and near the brink

Of Trent or Avon have a dwelling-place,

Where I may see my quill or cork down sink

With eager bite of perch, or bleak, or dace ;

And on the world and my Creator think:

Whilst some men strive ill-gotten goods t' embrace,

And others spend their time in base excess

Of wine, or worse, in war and wantonness.

Let them that list, these pastimes still pursue,

And on such pleasing fancies feed their fill ;

So I the fields and meadows green may view,

And daily by fresh rivers walk at will,

Among the daisies and the violets blue,

Red hyacinth and yellow daffodil,

Purple narcissus like the morning rays,

Pale gander-grass, and azure culverkeys.

I count it higher pleasure to behold

The stately compass of the lofty sky ;

And in the midst thereof, like burning gold,

The flaming chariot of the world's great eye ;

The watery clouds that, in the air up-roll'd,

With sundry kinds of painted colours fly;

And fair Aurora, lifting up her head,

Still blushing, rise from old Tithonus' bed.

The hills and mountains raised from the plains,

The plains extended level with the ground;

The grounds divided into sundry veins,

The veins enclos'd with rivers running round; 
These rivers making way through nature's chains

With headlong course into the sea profound;

The raging sea, beneath the valleys low,

Where lakes and rills and rivulets do flow.

The lofty woods, the forests wide and long,

Adorn'd with leaves and branches fresh and green, In whose cool bowers the birds, with many a song,

Do welcome with their choir the summer's queen; The meadows fair, where Flora's gifts among

Are intermix'd, with verdant grass between ;

The silver-scaléd fish that softly swim

Within the sweet brook's crystal watery stream.

\section{All these, and many more of His creation}

That made the heavens, the angler oft doth sec ;

Taking therein no little delectation,

To think how strange, how wonderful they be !

Framing thereof an inward contemplation

To set his heart from other fancies free ; And whilst he looks on these with joyful eye, His mind is rapt above the starry sky.

Sir, I am glad my memory has not lost these last verses, because they are somewhat more pleasant and more suitable to May-day than my harsh discourse. And I am glad your patience hath held out so long, as to hear them and me; for both together have brought us within the sight of the Thatched House. And I must be your debtor, if you think it worth your attention, for the rest of my promised discourse, till some other opportunity, and a like time of leisure.

VEN. Sir, you have angled me on with much pleasure to the Thatched House; and I now find your words true, " that good company makes the way seem short" ; for trust me, Sir, I thought we had wanted three miles of this house, till you shewed it me. But now we are at it, we'll turn into it, and refresh ourselves with a cup of drink, and a little rest. 
PIsc. Most gladly, Sir, and we'll drink a civil cup to all the otter-hunters that are to meet you to-morrow.

Ven. That we will, Sir, and to all the lovers of angling, of which number I am now willing to be one myself ; for, by the help of your good discourse and company, I have put on new thoughts both of the art of angling, and of all that profess it: and if you will but meet me to-morrow, at the time and place appointed, and bestow one day with me and my friends in hunting the otter, I will dedicate the next two days to wait upon you, and we two will for that time do nothing but angle, and talk of fish and fishing.

PIsc. 'Tis a match, Sir; I'll not fail you, God willing, to be at Amwell Hill to-morrow morning before sun-rising. 


\section{CHAPTER II}

OBSERVATIONS OF THE OTTER AND CHUB

\section{[ฐecono Dap]}

VEN. My friend Piscator, you have kept time with my thoughts, for the sun is just rising, and I myself just now come to this place, and the dogs have just now put down an otter. Look down at the bottom of the hill there in that meadow, checquered with water-lilies and lady-smocks; there you may see what work they make : look! look! you may see all busy, men and dogs, dogs and men all busy.

PIsc. Sir, I am right glad to meet you, and glad to have so fair an entrance into this day's sport, and glad to see so many dogs and more men all in pursuit of the otter. Let us compliment no longer, but join unto them. Come, honest Venator, let us be gone, let us make haste; I long to be doing; no reasonable hedge or ditch shall hold me.

VEN. Gentleman-huntsman, where found you this otter?

Hunt. Marry, Sir, we found her a mile from this place, a-fishing. She has this morning eaten the greatest part of this trout; she has only left thus much of it as you see, and was fishing for more; when we came we found her just at it; but we were here very early, we were here an hour before sunrise, and have-given her no rest since we came; sure, she will hardly escape all these dogs and men. I am to have the skin, if we kill her.

VEN. Why, Sir, what is the skin worth ? 
Hunt. It is worth ten shillings to make gloves; the gloves of an otter are the best fortification for your hands that can be thought on against wet weather.

PIsc. I pray, honest huntsman, let me ask you a pleasant question; do you hunt a beast or a fish ?

Hunt. Sir, it is not in my power to resolve you; I leave it to be resolved by the College of Carthusians, who have made vows never to eat flesh. But I have heard the question hath been debated among many great clerks, and they seem to differ about it; yet most agree that her tail is fish-; and if her body be fish too, then I may say that a fish will walk upon land; for an otter does so, sometimes, five or six or ten miles in a night, to catch for her young ones, or to glut herself with fish. And I can tell you that pigeons will fly forty miles for a breakfast ; but, sir, I am sure the otter devours much fish, and kills and spoils much more than he eats. And I can tell you that this dog-fisher, for so the Latins call him, can smell a fish in the water a hundred yards from him; Gesner says much farther: and that his stones are good against the falling sickness ; and that there is an herb, benione, which being hung in a linen cloth, near a fish pond, or any haunt that he uses, makes him to avoid the place; which proves he smells both by water and land; and I can tell you there is brave hunting this water-dog in Cornwall, where there have been so many, that our learned Camden says, there is a river called Ottersey, which was so named, by reason of the abundance of otters that bred and fed in it.*

* The reader need hardly be told, that neither the tail nor any other part of the otter is "fish." "The otter will live upon land, and can be trained to hunt and catch fish for its master. Fish is not its only food ; and it has been guilty of nocturnal attacks on henroosts, rabbit-hutches, etc. It seldom or never eats the whole of a fish. What is called the " otter's bite," or bonne bouche, is that part of the fish between the poll or neck and dorsal fin. The tail part of a fish is not succulent enough for the palate of this gourmet. There is no animal of its size that has stronger jaws and tecth than the 
And thus much for my knowledge of the otter, which you may now see above water at vent, and the dogs close with him ; I now see he will not last long, follow therefore my masters, follow, for Sweetlips was like to have him at this last vent.*

VEN. Oh me! all the horse are got over the river, what shall we do now? Shall we follow them over the water?

Hunt. No, sir, no, be not so eager; stay a little and follow me, for both they and the dogs will be suddenly on this side again I warrant you ; and the otter too, it may be : now have at him with Kilbuck, for he vents again.

VEN. Marry so he does, for look he vents in that corner. Now, now Ringwood has him : now he's gone again, and has bit the poor dog. Now Sweetlips has her; hold her, Sweetlips! now all the dogs have her, some above and some under water; but now, now she's tired, and past losing : come bring her to me, Sweetlips. Look, 'tis a bitch-otter, and she has lately whelped. Let's go to the place where she was put down, and not far from it you will find all her young ones, I dare warrant you, and kill them all too.

Hunt. Come, gentlemen, come all, let's go to the place where we put down the otter. Look you, hereabout it was that she kennelled; look you, here it was indeed, for here's her young ones, no less than five; come let's kill them all.

Pisc. No, I pray Sir, save me one, and I'll try if I can make her tame, as I know an ingenious gentleman in Leicestershire, Mr. Nicholas Seagrave, has done; who

otter; and in its contests with dogs, it seldom fails to fracture, by biting through one or two of their fore-legs. No dog can bite through the body-skin (so thickly covered is it with impenetrable fur) of the otter. The otter-hound that knows his business seizes his quarry by the head, and by crushing it comes off victorious.- E.

*I.e. view. The otter "vents" when he shows his head above water for the purpose of respiration (venting, "taking in wind"), after having been swimming under water to escape his pursuers.-E. 
hath not only made her tame, but to catch fish, and do many other things of much pleasure.

Hunt. Take one with all my heart, but let us kill the rest. And now let's go to an honest ale-house, where we may have a cup of good barley-wine, and sing "Old Rose," and all of us rejoice together.

VEN. Come, my friend Piscator, let me invite you along with us; I'll bear your charges this night, and you shall bear mine to-morrow; for my intention is to accompany you a day or two in fishing.

Pisc. Sir, your request is granted, and I shall be right glad both to exchange such a courtesy, and also to enjoy your company.

\section{[Tbiro Day]}

VEN. Well, now let's go to your sport of angling.

PIsc. Let's be going with all my heart. God keep you all, gentlemen, and send you meet this day with another bitch-otter, and kill her merrily, and all her young ones too.

Ven. Now, Piscator, where will you begin to fish?

Pisc. We are not yet come to a likely place, I must walk a mile further yet before I begin.

Ven. Well then, I pray, as we walk tell me freely, how do you like your lodging, and mine host, and the company? Is not mine host a witty man ?

PIsc. Sir, I will tell you presently what I think of your host : but first, I will tell you, I am glad these otters were killed; and I am sorry there are no more otterkillers; for I know that the want of otter-killers, and the not keeping the fence-months for the preservation of fish, will, in time, prove the destruction of all rivers. 
And those very few that are left, that make conscience of the laws of the nation, and of keeping days of abstinence, will be forced to eat flesh, or suffer more inconveniences than are yet foreseen.

VEN. Why, Sir, what be those that you call the fence-montlis ?

PIsc. Sir, they be principally three, namely, March, April, and May; for these be the usual months that salmon come out of the sea to spawn in most fresh rivers.* And their fry would, about a certain time, return back to the salt water, if they were not hindered by weirs and unlawful gins, which the greedy fishermen set, and so destroy them by thousands; as they would, being so taught by nature, change the fresh for salt water. $\mathrm{He}$ that shall view the wise statutes made in the 13th of Edward the I., and the like in Richard II., may see several provisions made against the destruction of fish : and though I profess no knowledge of the law, yet I am sure the regulation of these defects might be easily mended. But I remember that a wise friend of mine did usually say, "that which is everybody's business is nobody's business." If it were otherwise, there could not be so many nets and fish, that are under the statute size, sold daily amongst us; and of which the conservators of the waters should be ashamed.

But, above all, the taking fish in spawning-time may be said to be against nature; it is like the taking the dam on the nest when she hatches her young : a sin so against nature that Almighty God hath in the Levitical law made a law against it (Deut. xii. 6, 7).

But the poor fish have enemies enough besides such unnatural fishermen, as namely, the otters that I spake

- Walton is wrong in his natural history. No salmon spawn in April and May; a very small number of late fish spawn in March. Early salmon spawn in September; but the general spawning season is from the middle of November to the middle of December.-E. 
of, the cormorant, the bittern, the osprey, the sea-gull, the heron, the king-fisher, the gorara, the puet, the swan, goose, ducks, and the craber, which some call the waterrat: against all which any honest man might make a just quarrel, but I will not, I will leave them to be quarrelled with, and killed by others; for I am not of a cruel nature, I love to kill nothing but fish.

And now to your question concerning your host; to speak truly, he is not to me a good companion : for most of his conceits were either Scripture-jests, or lascivious jests, for which I count no man witty, for the Devil will help a man that way inclined, to the first; and his own corrupt nature, which he always carries with him, to the latter; but a companion that feasts the company with wit and mirth, and leaves out the sin which is usually mixed with them, he is the man; and indeed such a man should have his charges borne, and to such company I hope to bring you this night; for at Trout Hall, not far from this place, where I purpose to lodge to-night, there is usually an angler that proves good company : and let me tell you, good company and good discourse are the very sinews of virtue : but for such discourse as we heard last night, it infects others ; the very boys will learn to talk and swear, as they heard mine host,* and another of the company that shall be nameless ; - I am sorry the other is a gentleman; for less religion will not save their souls than a beggar's: I think more will be required at the last great day. Well! you know what example is able to do ; and I know what the poet says in the like case,-which is worthy to be noted by all parents and people of civility :

\section{... many a one}

Owes to his country his religion;

And in another would as strongly grow,

Had but his nurse or mother taught him so.

* Of the Thatched House, at Hoddesden, where Piscator passed the first night. 
This is reason put into verse, and worthy the consideration of a wise man. But of this no more; for though I love civility, yet I hate severe censures. I'll to my own art; and I doubt not but at yonder tree I shall catch a chub: and then we'll turn to an honest cleanly hostess, that I know right well ; rest ourselves there; and dress it for our dinner.

Ven. Oh, Sir ! a chub is the worst fish that swims; I hoped for a trout to my dinner.

PISc. Trust me, Sir, there is not a likely place for a trout hereabout: and we staid so long to take leave of your huntsmen this morning, that the sun is got so high, and shines so clear, that I will not undertake the catching of a trout till evening. And though a chub be, by you and many others, reckoned the worst of fish; yet you shall see I'll make it a good fish by dressing it.

VEN. Why, how will you dress him ?

PIsc. I'll tell you by and by, when I have caught him. Look you here, Sir, do you see? (but you must stand very close), there lie upon the top of the water, in this very hole, twenty chubs. I'll catch only one, and that shall be the biggest of them all: and that I will do so, I'll hold you twenty to one, and you shall see it done.

VEN. Ay, marry, Sir, now you talk like an artist, and I'll say you are one, when I shall see you perform what you say you can do; but I yet doubt it.

Pisc. You shall not doubt it long, for you shall see me do it presently: look, the biggest of these chubs has had some bruise upon his tail by a pike, or some other accident, and that looks like a white spot; that very chub I mean to put into your hands presently; sit you but down in the shade, and stay but a little while, and I'll warrant you I'll bring him to you.

VEN. I'll sit down, and hope well, because you seem to be so confident. 
Pisc. Look you, Sir, there is a trial of my skill,* there he is, that very chub that I showed you with the white spot on his tail : and I'll be as certain to make him a good dish of meat, as I was to catch him. I'll now lead you to an honest ale-house where we shall find a cleanly room, lavender in the windows, and twenty ballads stuck about the wall ; there my hostess, which, I may tell you, is both cleanly and handsome, and civil, liath dressed many a one for me, and shall now dress it after my fashion, and I warrant it good meat.

Ven. Come, Sir, with all my heart, for I begin to be

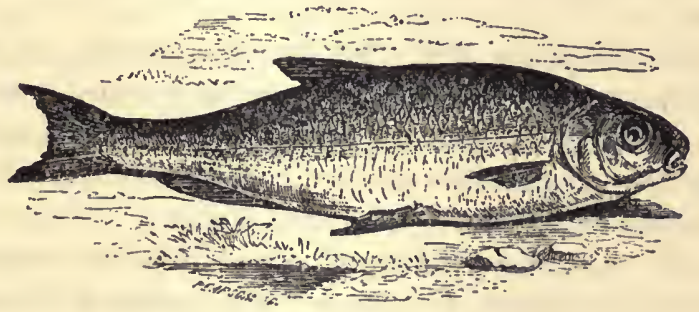

CHUB

hungry, and long to be at it, and indeed to rest myself too; for though I have walked but four miles this morning, yet I begin to be weary; yesterday's hunting hangs still upon me.

Pisc. Well, Sir, you shall quickly be at rest, for yonder is the house I mean to bring you to.

Come, Hostess, how do you ? Will you first give me a cup of your best drink, and then dress this chub as you dressed my last, when I and my friend were here about eight or ten days ago ? But you must do me one courtesy, it must be done instantly.

- Walton does not explain the particulars of his trial of skill. Evidently the chub was caught by dibbing or daping with a natural insect. See the seventh paragraph of chap. iii., beginning, "Go to the same hole," etc.-E. 
Hostess. I will do it, Mr. Piscator, and with all the speed I can.

Pisc. Now, Sir, has not my Hostess made haste? and does not the fish look lovely?

VEN. Both, upon my word, Sir, and therefore let's say grace, and fall to eating of it.

PIsc. Well, Sir, how do you like it ?

Ven. Trust me, 'tis as good meat as I ever tasted : now let me thank you for it, drink to you, and beg a courtesy of you; but it must not be denied me.

Pisc. What is it, I pray, Sir? You are so modest, that methinks I may promise to grant it before it is asked.

VEN. Why, Sir, it is, that from henceforth you would allow me to call you Master, and that really I may be your scholar; for you are such a companion, and have so quickly caught, and so excellently cooked this fish, as makes me ambitious to be your scholar.

PIsc. Give me your hand; from this time forward I will be your master, and teach you as much of this art as I am able; and will, as you desire me, tell you somewhat of the nature of most of the fish that we are to angle for ; and I am sure I both can and will tell you more than any common Angler yet knows. 


\section{CHAPTER III}

HOW TO FISH FOR, AND TO DRESS, THE CHAVENDER, OR CHUB

\section{[Tbiro \$ay]}

PIsc. The Chub, though he eat well thus dressed, yet as he is usually dressed, he does not. He is objected against, not only for being full of small forked bones, dispersed through all his body, but that he eats waterish, and that the flesh of him is not firm, but short and tasteless. The French esteem him so mean as to call him un vilain; nevertheless, he may be so dressed as to make him very good meat; as, namely, if he be a large chub, then dress him thus :-

First, scale him, and then wash him clean, and then take out his guts; and to that end make the hole as little, and near to his gills, as you may conveniently, and especially make clean his throat from the grass and weeds that are usually in it; for if that be not very clean, it will make him to taste very sour. Having so done, put some sweet herbs into his belly; and then tie him with two or three splinters to a spit, and roast him, basted often with vinegar, or rather verjuice and butter, with good store of salt mixed with it. Being thus dressed, you will find him a much better dish of meat than you, or most folk, even than anglers themselves, do imagine: for this dries up the fluid watery humour with which all chubs do abound.

But take this rule with you, that a chub newly taken and newly dressed is so much better than a chub of 
a day's keeping after he is dead, that I can compare him to nothing so fitly as to cherries newly gathered from a tree, and others that have been bruised and lain a day or two in water. But the chub being thus used, and dressed presently, and not washed after he is gutted (for note, that lying long in water, and washing the blood out of any fish after they be gutted, abates much of their sweetness), you will find the chub (being dressed in the blood, and quickly) to be such meat as will recompense your labour, and disabuse your opinion.

Or, you may dress the chavender or chub thus :-

When you have scaled him, and cut off his tail and fins, and washed him very clean, then chine or slit him through the middle, as a salt fish is usually cut; then give him three or four cuts or scotches on the back with your knife, and broil him on charcoal, or wood-coal that is free from smoke, and all the time he is a-broiling baste him with the best sweet butter, and good store of salt mixed with it ; and to this add a little thyme cut exceeding small, or bruised into the butter. The cheven thus dressed hath the watery taste taken away, for which so many except against him. Thus was the cheven dressed that you now liked so well, and commended so much. But note again, that if this chub that you ate of, had been kept till to-morrow, he had not been worth a rush. And remember that his throat be washed very clean, I say very clean, and his body not washed after he is gutted, as indeed no fish should be.

Well, scholar, you see what pains I have taken to recover the lost credit of the poor despised chub. And now I will give you some rules how to catch him; and I am glad to enter you into the art of fishing by catching a chub, for there is no fish better to enter a young angler, he is so easily caught, but then it must be this particular way.

Go to the same hole in which I caught my chub, where 
in most hot days you will find a dozen or twenty chevens floating near the top of the water: get two or three grasshoppers as you go over the meadow, and get secretly behind the tree, and stand as free from motion as is possible; then put a grasshopper on your hook, and let your hook hang a quarter of a yard short of the water, to which end you must rest your rod on some bough of the tree. But it is likely the chubs will sink down towards the bottom of the water, at the first shadow of your rod (for chub is the fearfulest of fishes), and will do so if but a bird flies over him and makes the least shadow on the water. But they will presently rise up to the top again, and there lie soaring till some shadow affrights them again. I say, when they lie upon the top of the water, look out the best chub (which you, setting yourself in a fit place, may very easily see), and move your rod as softly as a snail moves, to that chub you intend to catch; let your bait fall gently upon the water about three or four inches before him, and he will infallibly take the bait. And you will be as sure to catch him ; for he is one of the leather-mouthed fishes,* of which a hook does scarce ever lose its hold; and therefore give him play enough before you offer to take lim out of the water. Go your way presently; take my rod and do as I bid you; and I will sit down and mend my tackling till you return back.

Ven. Truly, my loving master, you have offered me as fair as I could wish. I'll go, and observe your directions.

Look you, master, what I have done, that which joys my heart,-caught just such another chub as yours was.

* Leather-mouthed fish are those possessing tough palates; they are generally of the carp tribe. The barbel is a good example. Tender-mouthed fish are mostly of the salmon tribe, with crisp and tender palates. The latter fish, when hooked, must be played with a delicate hand, lest the hook-hold tear away; the former can be played roughly without any such danger.-E. 
Pisc. Marry, and I am glad of it: I am like to have a towardly scholar of you. I now see, that with advice and practice, you will make an angler in a short time. Have but a love to it ; and I'll warrant you.

VEN. But, master, what if I could not have found a grasshopper?

Pisc. Then I may tell you, that a black snail, with his belly slit to show his white, or a piece of soft cheese,* will usually do as well. Nay, sometimes a worm, or any kind of fly, as the ant-fly, the flesh-fly, or wall-fly; or the dor or beetle, which you may find under cowdung, or a bob, which you will find in the same place, and in time will be a beetle; it is a short white worm, like to and bigger than a gentle, or a cod-worm, or a case-worm, any of these will do very well to fish in such a manner. And after this manner you may catch a trout in a hot evening: when as you walk by a brook, and shall see or hear him leap at flies, then if you get a grasshopper, put it on your hook, with your line about two yards long, standing behind a bush or tree where his hole is, and make your bait stir up and down on the top of the water, you may, if you stand close, be sure of a bite, but not sure to catch him, for he is not a leathermouthed fish : and after this manner you may fish for him with almost any kind of live fly, but especially with a grasshopper.

VEN. But before you go further, I pray, good master, what mean you by a leather-mouthed fish?

PIsc. By a leather-mouthed fish I mean such as have their teeth in their throat, as the chub or cheven, and so the barbel, the gudgeon, and carp, and divers others have; and the hook being stuck into the leather or skin, or the mouth of such fish, does very seldom

In fishing with cheese, snails, or worms, you must not angle at the top dr surface of the water, but at the bottom, with leaded line and middle-sized float.-E. 
or never lose its hold: but, on the contrary, a pike, a perch, or trout, and so some other fish, which have not their teeth in their throats, but in their mouths, which you shall observe to be very full of bones, and the skin very thin, and little of it: I say, of these fish the hook never takes so sure hold, but you often lose your fish, unless he have gorged it.

VEN. I thank you, good master, for this observation; but now, what shall be done with my chub or cheven that I have caught?

Pisc. Marry, Sir, it shall be given away to some poor body, for I'll warrant you I'll give you a trout for your supper : and it is a good beginning of your art to offer your first-fruits to the poor, who will both thank you and God for it, which I see by your silence you seem to consent to. And for your willingness to part with it so charitably, I will also teach more concerning chubfishing: you are to note that in March and April he is usually taken with worms ; in May, June, and July, he will bite at any fly, or at cherries, or at beetles with their legs and wings cut off, or at any kind of snail, or at the black bee that breeds in clay walls. And he never refuses a grasshopper, on the top of a swift stream,* nor, at the bottom, the young humble-bee that breeds in long grass, and is ordinarily found by the mower of it. In August, and in the cooler months, a yellow paste, made of the strongest cheese, and pounded in a mortar, with a little butter and saffron, so much of it, as being beaten small, will turn it to a lemon colour. And some make a paste, for the winter months, at which time the chub is accounted best (for then it is observed that the forked bones are lost, or turned into a kind of

* In the Thames, above Richmond, the best way of using the grasshopper for chub, is to fish with it as with an artificial fly; the first joints of the legs must be pinehed off ; and in this way, when the weed is rotten, which is seldom till September, the largest dace are taken.-H. 
gristle, especially if he be baked), of cheese and turpentine. He will bite also at a minnow, or penk, as a trout will : of which I shall tell you more hereafter, and of divers other baits. But take this for a rule, that, in hot weather, he is to be fished for towards the mid-water, or near the top; and in colder weather nearer the bottom. And if you fish for him on the top, with a beetle, or any fly, then be sure to let your line be very long and to keep out of sight. And having told you that his spawn is excellent meat, and that the head of a large cheven, the throat being well washed, is the best part of him, I will say no more of this fish at the present, but wish you may catch the next you fish for.*

But, lest you may judge me too nice in urging to have the chub dressed so presently after he is taken, I will commend to your consideration how curious former times have been in the like kind.

You shall read in Seneca his Natural Questions, lib. 3, cap. 17 , that the ancients were so curious in the newness of their fish, that that seemed not new enough that was not put alive into the guest's hand; and he says that to that end they did usually keep them living in glass bottles in their dining-rooms : and they did glory much in their entertaining of friends, to have that fish taken from under their table alive that was instantly to be fed upon. And he says, they took great pleasure to see their mullets change to several colours, when they were dying. But enough of this, for I doubt I have stayed too long from giving you some observations of the trout, and how to fish for him, which shall take up the next of my spare time.

- Piscator gives in this paragraph some very good advice touching angling for chub. Walton understood the matter well, and was no doubt a great adept in the art of fishing for chub and barbel. However, chub very rarely indeed take the minnow, or any other sort of fish-bait. Lob-worms, gentles, prepared cheese, honeypaste, insects, natural and artificial, are the best baits for them.-E. 


\section{CHAPTER IV}

OBSERVATIONS OF THE NATURE AND BREEDING OF THE TROUT, AND HOW TO FISH FOR HIM ; AND THE MILKMAID'S SONG

\section{[Cbiro Day]}

THE Trout is a fish highly valued both in this and foreign nations: he may be justly said, as the old poet said of wine, and we English say of venison, to be a generous fish: a fish that is so like the buck that he also has his seasons; for it is observed, that he comes in and goes out of season with the stag and buck; Gesner says, his name is of a German offspring, and says he is a fish that feeds clean and purely, in the swiftest streams, and on the hardest gravel; and that he may justly contend with all fresh-water fish, as the mullet may with all sea-fish, for precedency and daintiness of taste, and that being in right season, the most dainty palates have allowed precedency to him.

And before I go farther in my discourse, let me tell you, that you are to observe, that as there be some barren does, that are good in summer, so there be some barren trouts that are good in winter; but there are not many that are so, for usually they be in their perfection in the month of May, and decline with the buck. Now you are to take notice, that in several countries, as in Germany and in other parts, compared to ours, fish differ much in their bigness and shape, and other ways, and so do trouts; it is well known that in the Lake Leman, the Lake of Geneva, there are trouts taken of three cubits 
long, as is affirmed by Gesner, a writer of good credit; and Mercator* says, the trouts that are taken in the Lake of Geneva, are a great part of the merchandise of that famous city. And you are further to know, that there be certain waters, that breed trouts remarkable both for their number and smallness. I know a little brook in Kent, that breeds them to a number incredible, and you may take them twenty or forty in an hour, but none greater than about the size of a gudgeon: there are also in divers rivers, especially that relate to, or be near to the sea, as Winchester, or the Thames about Windsor, a little trout called samlet, or skegger trout (in both which places I have caught twenty or forty at a standing), that will bite as fast and as freely as minnows : these be by some taken to be young salmon; but in those waters they never grow to be bigger than a herring. $t$

There is also in Kent, near to Canterbury, a trout called there a Fordidge trout, a trout that bears the name of the town where it is usually caught, that is

* Gerard Mercator, of Ruremond in Flanders, a man of so intense application to mathematical studies, that he neglected the necessary refreshments of nature. He engraved with his own hand, and coloured the maps to his geographical writings. He wrote several books of theology; and died 1594.-H.

$\dagger$ The skegger here alluded to is no doubt the young salmon in its first year, before it has paid its first visit to the sea. As salmon have disappeared from the Thames, so have skeggers, or salmon fry. The Lake of Geneva still produces very large trout, which are frequently cooked on the spot, and sent express to Paris. Still, I do not think that any of them now grow to the length of " three cubits." They are not unfrequently caught weighing twenty-four or thirty pounds. Trout every bit as large are caught in some of the loughs and lochs of Ireland and Scotland. The smallest species of trout is now called "the parr," and very likely that is the fish to which Walton alludes in this passage,- "I know a little brook in Kent, that breeds them to a number incredible, and you may take them twenty or forty in an hour, but none greater than about the size of a gudgeon." When Walton mentions "barren trouts, that are good in winter," he falls into a common error. The barren trout are really male trout, which have shed their milt over the ova of the female fish in the early spawning months, August and September. The male fish very rapidly recovers from the exhausting process of procreation. Not so the female, which, if a large fish, is not fully convalescent until the May next following her accouchement.-E. 
accounted the rarest of fish; many of them near the bigness of a salmon, but known by their different colour ; and in their best season they cut very white; and none of these have been known to be caught with an angle, unless it were one that was caught by Sir George Hastings, an excellent angler, and now with God: and he hath told me, he thought that trout bit not for hunger but wantonness; and it is rather to be believed, because both he, then, and many others before him, have been curious to search into their bellies, what the food was by which they lived; and have found out nothing by which they might satisfy their curiosity.

Concerning which you are to take notice, that it is reported by good authors, that grasshoppers, and some fish, have no mouths, but are nourished and take breath by the porousness of their gills, man knows not how : and this may be believed, if we consider that when the raven hath hatched her eggs, she takes no farther care, but leaves her young ones to the care of the God of nature, who is said, in the Psalms, "to feed the young ravens that call upon him." And they be kept alive, and fed by dew, or worms that breed in their nests, or some other ways that we mortals know not; and this may be believed of the Fordidge trout, which, as it is said of the stork (Jerem. viii. 7), that " he knows his season," so he knows his times, I think almost his day of coming into that river out of the sea, where he lives, and, it is like, feeds nine months of the year, and fasts three in the river of Fordidge. And you are to note that those townsmen are very punctual in observing the time of beginning to fish for them; and boast much that their river affords a trout, that exceeds all others. And just so does Sussex boast of several fish ; as namely, a Shelsey cockle, a Chichester lobster, an Arundel mullet, and an Amerly trout.

And now for some confirmation of the Fordidge trout : you are to know that this trout is thought to eat nothing 
in the fresh water;* and it may be better believed, because it is well known, that swallows and bats and wagtails, which are called half-year birds, and not seen to fly in England for six months in the year, but about Michaelmas leave us for a better climate than this; yet some of them that have been left behind their fellows, have been found many thousands at a time, in hollow trees, or clay caves ; where they have been observed to live and sleep out the whole winter without meat; and so Albertus observes, that there is one kind of frog that hath her mouth naturally shut up about the end of August, and that she lives so all the winter: and though it be strange to some, yet it is known to too many among us to be doubted.

And so much for these Fordidge trouts, which never afford an angler sport, but either live their time of being in the fresh water, by their meat formerly got in the sea (not unlike the swallow or frog), or by the virtue of the fresh water only; or, as the birds of Paradise and the chamelion are said to live, by the sun and the air.

There is also in Northumberland a trout called a bulltrout, of a much greater length and bigness than any in the southern parts. And there are, in many rivers that relate to the sea, salmon-trouts, as much different from others, both in shape and in their spots, as we see sheep in some countries differ one from another in their shape and bigness, and in the fineness of their wool. And, certainly, as some pastures breed larger sheep, so do some rivers, by reason of the ground over which they run, breed larger trouts.

* There is no species of trout whatsoever that does not feed in fresh water. The sea trout (salmo trutta) and the bull trout (salmo ferox), though they migrate to sea, like the salmon, and for a time thrive and fatten therein, return to their native rivers, and feed on small fish and insects; indeed, they are the greatest destroyers of salmon-fry. There is no fish that has its mouth sewn up as it were; and what Walton says about grasshoppers and frogs having no mouths is simply laughable. All thai Valton says of the Fordidge, a river near Canterbury, and of ravens, etc., is perfectly fabulous.-E. 
Now the next thing that I will commend to your consideration is, that the trout is of a more sudden growth than other fish. Concerning which, you are also to take notice, that he lives not so long as the perch, and divers other fishes do, as Sir Francis Bacon hath observed in his History of Life and Death.

And now you are to take notice, that he is not like the crocodile, which if he lives never so long, yet always thrives till his death. And you are to know, that he will about, especially before, the time of his spawning, get almost miraculously through weirs and flood-gates against the streams; even through such high and swift places as is almost incredible. Next, that the trout usually spawns about October or November, but in some rivers a little sooner or later: which is the more observable, because most other fish spawn in the spring or summer, when the sun hath warmed both the earth and the water, and made it fit for generation. And you are to note, that he continues many months out of season ; for it may be observed of the trout, that he is like the buck or the ox, that he will not be fat in many months, though he go in the very same pasture that horses do, which will be fat in one month : and so you may observe, that most other fishes recover strength, and grow sooner fat and in season, than the trout doth.

And next you are to note, that till the sun gets to such a height as to warm the earth and the water, the trout is sick and lean, and lousy, and unwholesome : for you shall in winter find him to have a big head, and then to be lank, and thin, and lean : at which time many of them have sticking on them sugs, or trout-lice, which is a kind of worm, in shape like a clove or pin, with a big head, and sticks close to him and sucks his moisture; those I think, the trout breeds himself, and never thrives till he free himself from them, which is when warm weather comes; and then, as he grows stronger, he gets from the dead, still 
water, into the sharp streams, and the gravel, and there rubs off these worms or lice; and then as he grows stronger, so he gets him into swifter and swifter streams, and there lies at the watch for any fly or minnow that comes near to him; and he especially loves the May-fly, which is bred of the cod-worm or cadis; and these make the trout bold and lusty, and he is usually fatter and better meat at that end of that month [May] than at any time of the year.

Now you are to know that it is observed, that usually the best trouts are either red or yellow; though some (as the Fordidge trout) be white and yet good; but that is not usual : and it is a note observable, that the female trout hath usually a less head, and a deeper body than the male trout, and is usually the better meat. And note, that a hog-back and a little head to either trout, salmon, or any other fish, is a sign that that fish is in season.

But yet you are to note, that as you see some willows or palm-trees bud and blossom sooner than others do, so some trouts be, in rivers, sooner in season: and as some hollies or oaks are longer before they cast their leaves, so are some trouts in rivers longer before they go out of season.

And you are to note, that there are several kinds of trouts : but these several kinds are not considered but by very few men; for they go under the general name of trouts : just as pigeons do, in most places ; though, it is certain, there are tame and wild pigeons; and of the tame, there be helmets and runts, and carriers and cropers, and indeed too many to name. Nay, the Royal Society have found and published lately, that there be thirty and three kinds of spiders; and yet all, for aught I know, go under that one general name of spider. And it is so with many kinds of fish, and of trouts especially; which differ in their bigness and shape and spots and colour. The great Kentish hens may be an instance, compared 
to other hens. And, doubtless, there is a-kind of small trout, which will never thrive to be big; that breeds very many more than others do, that be of a larger size : which you may rather believe, if you consider that the little wren and titmouse will have twenty young ones at a time,* when usually the noble hawk, or the musical thrassel or blackbird, exceed not four or five.

And now you shall see me try my skill to catch a trout; and at my next walking, either this evening, or to-morrow morning, I will give you direction how you yourself shall fish for him.

Ven. Trust me, master, I see now it is a harder matter to catch a trout than a chub : for I have put on patience, and followed you these two hours, and not seen a fish stir, neither at your minnow nor your worm.

Pisc. Well, scholar, you must endure worse luck sometime, or you will never make a good angler. But what say you now? There is a trout now, and a good one too, if I can but hold him, and two or three more turns will tire him. Now you see he lies still, and the sleight is, to land him ; reach me that landing net; so, Sir, now he is mine own, what say you now? Is not this worth all my labour and your patience?

Ven. On my word, master, this is a gallant trout; what shall we do with him ?

PIsc. Marry, e'en eat him to supper : we'll go to my hostess, from whence we came; she told me, as I was going out of door, that my brother Peter, a good angler and a cheerful companion, had sent word that he would lodge there to-night, and bring a friend with him. My hostess has two beds, and I know you and I may have the best; we'll rejoice with my brother Peter and his friend,

* If Walton had said half the number, he would have been right. The wren will sometimes lay a dozen eggs, but cannot hatch the whole of them.-E. 
tell tales, or sing ballads, or make a catch, or find some harmless sport to content us and pass away a little time, without offence to God or man.

VEN. A match, good master, let's go to that house; for the linen looks white, and smells of lavender, and I long to lie in a pair of sheets that smell so. Let's be going, good master, for I am hungry again with fishing.

Pisc. Nay, stay a little, good scholar; I caught my last trout with a worm ; now I will put on a minnow, and try a quarter of an hour about yonder trees for another ; and so walk towards our lodging. Look you, 'scholar, thereabout we shall have a bite presently or not at all. Have with you, Sir? o' my word I have hold of him. Oh ! it is a great logger-headed chub ; come hang him upon that willow twig, and let's be going. But turn out of the way a little, good scholar! towards yonder high honeysuckle hedge; there we'll sit and sing, whilst this shower falls so gently upon the teeming earth, and gives yet a sweeter smell to the lovely flowers that adorn these verdant meadows.

Look ! under that broad beech tree I sat down, when I was last this way a-fishing. And the birds in the adjoining grove seemed to have a friendly contention with an echo, whose dead voice seemed to live in a hollow tree, near to the brow of that primrose hill. There I sat viewing the silver streams glide silently towards their centre, the tempestuous sea; yet sometimes opposed by rugged roots and pebble-stones, which broke their waves, and turned them into foam. And sometimes I beguiled time by viewing the harmless lambs; some leaping securely in the cool shade, whilst others sported themselves in the cheerful sun; and saw others craving comfort from the swollen udders of their bleating dams. As I thus sat, these and other sights had so fully possessed my soul with content, that I thought, as the poet hath happily expressed it, 
"I was for that time lifted above earth, And possess'd joys not promised in my birth."

As I left this place, and entered into the next field, a second pleasure entertained me; 'twas a handsome milkmaid, that had not yet attained so much age and wisdom, as to load her mind with any fears of many things that will never be, as too many men often do: but she cast away all care, and sung like a nightingale : her voice was good, and the ditty fitted for it: it was that smooth song which was made by Kit Marlowe, now at least fifty years ago : and the milk-maid's mother sung an answer to it, which was made by Sir Walter Raleigh in his younger days.

They were old-fashioned poetry, but choicely good, I think much better than the strong lines that are now in fashion in this critical age. Look yonder! on my word, yonder they both be a-milking again. I will give her the chub, and persuade them to sing those two songs to us.

God speed you, good woman! I have been a-fishing, and am going to Bleak Hall to my bed, and having caught more fish than will sup myself and my friend, I will bestow this upon you and your daughter, for I use to sell none.

MiLK-W. Marry, God requite you, Sir, and we'll eat it cheerfully; and if you come this way a-fishing two months hence, a grace of God, I'll give you a syllabub of new verjuice in a new-made hay-cock for it, and my Miaudlin shall sing you one of her best ballads; for she and I both love all anglers, they be such honest, civil, quiet men; in the meantime will you drink a draught of red cow's milk? you shall have it freely.

Pisc. No, I thank you ; but, I pray, do us a courtesy that shall stand you and your daughter in nothing, and yet we will think ourselves still something in your debt; it is but to sing us a song that was sung by your daughter when I last passed over this meadow about eight or nine days since. 
MıLK-W. What song was it, I pray ? Was it "Come Shepherds, deck your heads?" or, "As at noon Dulcina rested ?" or, "Phillidaflouts me?" or, "Chevy Chace?" or, "Johnny Armstrong?" or, "Troy Town?"

Pisc. No, it is none of those; it is a song that your daughter sung the first part, and you sung the answer to it.

MiLK-W. O, I know it now. I learned the first part in my golden age, when I was about the age of my poor daughter; and the latter part, which indeed fits me best now, but two or three years ago, when the cares of the world began to take hold of me : but you shall, God willing, hear them both, and sung as well as we can, for we both love anglers: Come, Maudlin, sing the first part to the gentlemen with a merry heart, and I'll sing the second, when you have done.

\section{Tbe SiDilk=sibaid's \$ong}

Come live with me, and be my love, And we will all the pleasures prove That valleys, groves, or hills, or field, Or woods and steepy mountains yield;

Where we will sit upon the rocks, And see the shepherds feed our flocks By shallow rivers, to whose falls Melodious birds sing madrigals.

And I will make thee beds of roses, And then a thousand fragrant posies, A cap of flowers, and a kirtle Embroider'd all with leaves of myrtle ;

A gown made of the finest wool Which from our pretty lambs we pull ; Slippers lined choicely for the cold, With buckles of the purest gold ;

A belt of straw and ivy buds, With coral clasps and amber studs : And if these pleasures may thee move, Come live with me, and be my love. 
Thy silver dishes for my meat, As precious as the gods do eat, Shall, on an ivory table, be Prepared each day for thee and me.

The shepherd swains shall dance and sing, For thy delight, each May morning. If these delights thy mind may move, Then live with me, and be my love.*

Ven. Trust me, master, it is a choice song, and sweetly sung by honest Maudlin. I now see it was not without cause, that our good Queen Elizabeth did so often wish herself a milk-maid all the month of May, because they are not troubled with fears and cares, and sing sweetly all the day, and sleep securely all the night : and without doubt, honest, innocent, pretty Maudlin does so. I'll bestow Sir Thomas Overbury's milk-maid's wish upon her, "That she may die in the spring, and being dead, may have good store of flowers stuck round about her winding sheet." $\dagger$

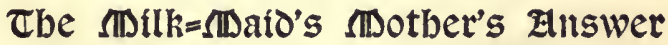

If all the world and love were young, And truth in every shepherd's tongue, These pretty pleasures might me move To live with thee, and be thy love.

- Dr. Warburton, in his Notes on The Merry Wives of Windsor, ascribes this song to Shakespeare. It is true, Sir Hugh Evans, in the third act of that play, sings four lines of it ; and it occurs in a collection of poems said to be Shakespeare's, printed by Tho. Cotes for John Benson, 12mo. 1640, with some variations. On the contrary, it is to be found, with the name of Christopher Marlowe to it, in England's Helicon (1600); and Walton has just said it was made by Kit Marlowe : the reader will judge of these evidences as he pleases.

As to the song itself, though a beautiful one, it is not so purely pastoral as it is generally thought to be ; buckles of gold, coral clasps, and amber studs-silver dishes and ivory tables-are luxuries, and consist not with the parsimony and simplicity of rural life and manners.

† Sir Thomas Overbury's " Character of a fair and happy Milkmaid," printed with his poem entitled " The Wife," in 12mo., 1665. 
But Time drives flocks from field to fold, When rivers rage and rocks grow cold ; Then Philomel becometh dumb, And age complains of care to come.

The flowers do fade, and wanton fields To wayward winter reckoning yields.

A honey tongue, a heart of gall, Is fancy's spring, but sorrow's fall.

Thy gowns, thy shoes, thy beds of roses, Thy cap, thy kirtle, and thy posies, Soon break, soon wither, soon forgotten; In folly ripe, in reason rotten.

Thy belt of straw and ivy buds, Thy coral clasps and amber studs, All these in me no means can move To come to thee, and be thy love.

What should we talk of dainties, then, Of better meat than's fit for men ? These are but vain : that's only good Which God hath bless'd, and sent for food.

But could youth last and love still breedHad joys no date, or age no needThen those delights my mind might move To live with thee, and be thy love.

Mother. Well ! I have done my song. But stay, honest anglers; for I will make Maudlin to sing you one short song more. Maudlin! sing that song that you sung last night, when young Coridon the shepherd played so purely on his oaten pipe to you and your cousin Betty.

MAUD. I will, mother.

I married a wife of late,

The more's my unhappy fate ;

I married her for love,

As my fancy did me move, And not for a worldly cstate; 
But, Oh! the green sickness

- Soon changed her likeness,

And all her beauty did fail.

But 'tis not so

With those that go

Through frost and snow,

As all men know,

And carry the milking-pail.

PIsc. Well sung, good woman; I thank you. I'll give you another dish of fish one of these days, and then beg another song of you. Come, scholar, let Maudlin alone; do not you offer to spoil her voice. Look, yonder comes mine hostess, to call us to supper. How now ? Is my brother Peter come?

Host. Yes, and a friend with him; they are both glad to hear that you are in these parts, and long to see you, and long to be at supper, for they be very hungry. 


\section{CHAPTER V}

MORE DIRECTIONS HOW TO FISH FOR, AND HOW TO MAKE FOR THE TROUT AN ARTIFICIAL MINNOW AND FLIES; WITH SOME MERRIMENT

\section{[Cbíro Đay]}

PIsc. Well met, brother Peter: I heard you and a friend would lodge here to-night, and that hath made me to bring my friend to lodge here too. My friend is one that would fain be a brother of the angle; he hath been an angler but this day, and I have taught him how to catch a chub by daping with a grass-hopper, and the chub that he caught was a lusty one of nineteen inches long. But pray, brother Peter, who is your companion?

Peter. Brother Piscator, my friend is an honest country-man, and his name is Coridon, and he is a downright witty companion, that met me here purposely to be pleasant and eat a trout, and I have not yet wetted my line since we met together; but I hope to fit him with a trout for his breakfast, for I'll be early up.

PIsc. Nay, brother, you shall not stay so long: for, look you, here is a trout will fill six reasonable bellies.

Come, hostess, dress it presently, and get us what other meat the house will afford, and give us some of your best barley-wine, the good liquor that our honest forefathers did use to drink of ; the drink which preserved their health, and made them live so long, and do so many good deeds.

Peter. O' my word, this trout is perfect in season. Come I thank you, and here is a hearty draught to you, 
and to all the brothers of the angle wheresoever they be, and to my young brother's good fortune to-morrow. I will furnish him with a rod if you will furnish him with the rest of the tackling; we will set him up and make him a fisher. And I will tell him one thing for his encouragement, that his fortune hath made him happy to be scholar to such a master; a master that knows as much, both of the nature and breeding of fish, as any man; and can also tell him as well how to catch and cook them, from the minnow to the salmon, as any that I ever met withal.

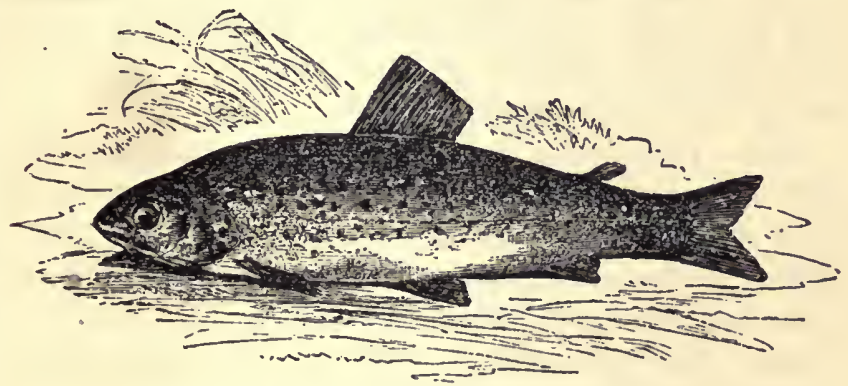

TROUT

Pisc. Trust me, brother Peter, I find my scholar to be so suitable to my own humour, which is, to be free and pleasant and civilly merry, that my resolution is to hide nothing that I know from him. Believe me, scholar, this is my resolution; and so here's to you a hearty draught, and to all that love us and the honest art of angling.

Ven. Trust me, good master, you shall not sow your seed in barren ground; for I hope to return you an increase answerable to your hopes: but, however, you shall find me obedient and thankful and serviceable to my best ability.

Pisc. 'Tis enough, honest scholar! come, let's to supper. Come, my friend Coridon, this trout looks lovely ; 
it was twenty-two inches when it was taken! and the belly of it looked, some part of it, as yellow as a marigold, and part of it as white as a lily; and yet, methinks, it looks better in this good sauce.

Coridon. Indeed, honest friend, it looks well, and tastes well: I thank you for it, and so doth my friend Peter, or else he is to blame.

Peter. Yes, and so do I, we all thank you ; and when we have supped, I will get my friend Coridon to sing you a song for requital.

Cor. I will sing a song, if anybody will sing another; else, to be plain with you, I will sing none: I am none of those that sing for meat, but for company: I say, "Tis merry in hall, when men sing all." *

Pisc. I'll promise you I'll sing a song that was lately made at my request by Mr. William Basse, one that hath made the choice songs of the Hunter in his Career, and of Tom of Bedlam, and many others of note; and this that I will sing, is in praise of angling.

Cor. And then mine shall be, the praise of a countryman's life : what will the rest sing of ?

Peter. I will promise you, I will sing another song in praise of angling to-morrow night; for we will not part till then, but fish to-morrow, and sup together, and the next day every man leave fishing, and fall to his business.

VEN. 'Tis a match; and I will provide you a song or a catch against then too, which shall give some addition of mirth to the company; for we will be civil, and as merry as beggars.

PIsc. 'Tis a match, my masters; let's e'en say grace, and turn to the fire, drink the other cup to wet our whistles, and so sing away all sad thoughts.

* Parody on the adage-

"It's merry in the hall

When beards wag all";

i.e. when all are eating. $-\mathrm{H}$. 
Come on, my masters, who begins ? I think it is best to draw cuts, and avoid contention.

PETER. It is a match.-Look, the shortest cut falls to Coridon.

Cor. Well, then, I will begin, for I hate contention.

\section{Corioon's Fong}

Oh, the sweet contentment The countryman doth find !

Heigh trolollie lollie loe,

Heigh trolollie lollie lee.

That quiet contemplation

Possesseth all my mind;

Then care away,

And wend along with me.

For courts are full of flattery, As hath too oft been tried ;

Heigh trolollie lollie loe, etc.

The city full of wantonness,

And both are full of pride:

Then care away, etc.

But Oh! the honest country man

Speaks truly from his heart ;

Heigh trolollie lollie loe, etc.

His pride is in his tillage,

His horses and his cart:

Then care away, etc.

Our clothing is good sheep skins, Grey russet for our wives;

Heigh trolollie lollie loe, etc.

'Tis warmth, and not gay clothing,

That doth prolong our lives :

Then care away, etc.

The ploughman, though he labour hard,

Yet on the holiday,

Heigh trolollie lollie loe, etc.

No emperor so merrily

Doth pass his time away :

Then care away, etc. 
To recompense our tillage,

The heavens afford us showers :

Heigh trolollie lollie loc, etc.

And for our sweet refreshments

'The earth affords us bowers :

Then care away, etc.

The cuckoo and the nightingale

Full merrily do sing,

Heigh trolollie lollie loe, etc.

And with their pleasant roundelays

Bid welcome to the spring:

Then care away, etc.

This is not half the happiness

The countryman enjoys;

Heigh trolollie lollie loe, etc.

Though others think they have as much,

Yet he that says so lies:

Then come away, turn

Countryman with me.-Jo. Chalkhill.*

PIsc. Well sung, Coridon; this song was sung with mettle, and it was choicely fitted to the occasion; I shall love you for it as long as I know you ; I would you were a brother of the angle; for a companion that is cheerful, and free from swearing and scurrilous discourse, is worth gold. I love such mirth as does not make friends ashamed to look upon one another next morning; nor men that cannot well bear it, to repent the money they spend when they be warmed with drink : and take this for a rule, you may pick out such times, and such companions, that you may make yourselves merrier for a little than a great deal of money ; for " "Tis the company and not the charge, that makes the feast:" and such a companion you prove, I thank you for it.

But I will not compliment you out of the debt that I

- This poet's works Walton edited in his 90th year-that of his death.-E. 
owe you ; and therefore I will begin my song, and wish it may be so well liked.

\section{The $\mathfrak{A n g l e r}$ 's Fong}

As inward love breeds outward talk, The hound some praise, and some the hawk;

Some, better pleased with private sport,

Use tennis ; some a mistress court :

But these delights I neither wish

Nor envy, while I freely fish.

Who hunts, doth oft in danger ride ;

Who hawks, lures oft both far and wide;

Who uses games, shall often prove

A loser ; but who falls in love

Is fetter'd in fond Cupid's snare :

My angle breeds me no such care.

Of recreation there is none

So free as fishing is alone ;

All other pastimes do no less

Than mind and body both possess ;

My hand alone my work can do,

So I can fish and study too.

I care not, I, to fish in seas-

Fresh rivers best my mind do please, Whose sweet calm course I contemplate, And seek in life to imitate :

In civil bounds I fain would keep,

And for my past offences weep.

And when the timorous trout I wait To take, and he devours my bait, How poor a thing, sometimes I find, Will captivate a greedy mind ;

And when none bite, I praise the wise,

Whom vain allurements ne'er surprise.

But yet, though while I fish I fast, I make good fortune my repast ; 
And thereunto my friend invite, In whom I more than that delight:

Who is more welcome to my dish

Than to my angle was my fish.

As well content no prize to take, As use of taken prize to make :

For so our Lord was pleaséd, when

He fishers made fishérs of men;

Where (which is in no other game)

A man may fish and praise His name.

The first men that our Saviour dear Did choose to wait upon Him here, Bless'd fishers were, and fish the last Food was that $\mathrm{He}$ on earth did taste :

I therefore strive to follow those

IVhom He to follow Him hath chose.

Cor. Well sung, brother, you have paid your debt in good coin. We anglers are all beholden to the good man that made this song : come, hostess, give us more ale, and let's drink to him.

And now let's every one go to bed, that we may rise early : but first let's pay our reckoning, for I will have nothing to hinder me in the morning, for my purpose is to prevent the sun-rising.

Peter. A match. Come, Coridon, you are to be my bedfellow. I know, brother, you and your scholar will lie together. But where shall we meet to-morrow-night ? for my friend Coridon and I will go up the water towards Ware.

Pisc. And my scholar and I will go down towards Waltham.

Cor. Then let's meet here, for here are fresh sheets that smell of lavender; and I am sure we cannot expect better meat or better usage in any place.

PETER. 'Tis a match. Good night to everybody!

PIsc. And so say I.

Ven. And so say I. 


\section{[Jourtb Фay]}

Pisc. Good morrow, good hostess ; I see my brothcr Peter is still in bed : come, give my scholar and me a morning drink, and a bit of meat to breakfast; and be sure to get a good dish of meat or two against supper, for we shall come home as hungry as hawks. Come, scholar, let's be going.

Ven. Well now, good master, as we walk towards the river give me direction, according to your promise, how I shall fish for a trout.

Pisc. My honest scholar, I will take this very convenient opportunity to do it.

The trout is usually caught with a worm or a minnow, which some call a penk, or with a fly, viz., either a natural or an artificial fly : concerning which three I will give you some observations and directions.

And, first, for worms : of these there be very many sorts : some breed only in the earth, as the earth-worm; others of or amongst plants, as the dug-worm ; and others breed either out of excrements, or in the bodies of living creatures, as in the horns of sheep or deer.; or some of dead flesh, as the maggot or gentle, and others.

Now these be most of them particularly good for particular fishes : but for the trout, the dew-worm, which some also call the lob-worm, and the brandling, are the chief ; and especially the first for a great trout, and the latter for a less. There be also of lob-worms some called squirreltails, a worm that has a red head, a streak down the back, and a broad tail, which are noted to be the best, because they are the toughest and most lively, and live longest in the water: for you are to know that a dead worm is but a dead bait, and like to catch nothing, compared to a lively, quick, stirring worm: and for a brandling, he is usually found in an old dunghill, or some very rotten 
place near to it : but most usually in cow-dung, or hog's dung, rather than loorse-dung, which is somewhat too hot and dry for that worm. But the best of them are to be found in the bark of the tanners, which they cast up in hcaps after they have used it about their leather.

There are also divers other kinds of worms, which for colour and shape alter even as the ground out of which they are got; as the marsh-worm, the tag-tail, the flagworm, the dock-worm, the oak-worm, the gilt-tail, the twachel, or lob-worm,* which of all others is the most excellent bait for a salmon; and too many to name, even as many sorts as some think there be of several herbs or shrubs, or of several kinds of birds in the air ; of which I shall say no more, but tell you that what worms soever you fish with are the better for being well scoured, that is, long kept before they be used : and in case you have not been so provident, then the way to cleanse and scour them quickly is to put them all night in water, if they be lobworms, and then put them into your bag with fennel. But you must not put your brandlings above an hour in water, and then put them into fennel, for sudden use : but if you have time, and purpose to keep them long, then they be best preserved in an earthen pot, with good store of

* To avoid confusion, it may be necessary to remark, that the same kind of worm is, in different places, known by different names ; thus the marsh and the meadow-worm are the same; and the lobworm or twachel is also called the dew-worm, and the garden-worm; and the dock-worm is, in some places, called the flag-worm.

The tag-tail is found in March and April, in marled lands or meadows, after a shower of rain; or in the morning, when the weather is calm, and not cold.

To find the oak-worm, beat on an oak-tree that grows over a highway or bare place, and they will fall for you to gather.

To find the dock-worm, go to an old pond or pit, and pull up some of the flags; shake the roots in the water; and anongst the fibres that grow from the roots you will find little husks, or cases, of a reddish or yellowish colour; open these carefully with a pin, and take from them a little worm, pale yellow, or white, like a gentle, but longer and slenderer, with rows of feet down his belly, and a red head : this is the dock or flag-worm. An excellent bait for grayling, tench, bream, carp, roach, and dace. $-\mathrm{H}$. 
moss, which is to be fresh every three or four days in summer, and every week or eight days in winter; or, at least, the moss taken from them, and clean washed, and wrung betwixt your hands till it be dry, and then put it to them again. And when your worms, especially the brandling, begins to be sick and lose of his bigness, then you may recover him by putting a little milk or cream, about a spoonful in a day, into them, by drops on the moss; and if there be added to the cream an egg beaten and boiled in it, then it will both fatten and preserve them long.* And note, that when the knot, which is near to the middle of the brandling, begins to swell, then he is sick; and, if he be not well looked to, is near dying. And for moss, you are to note, that there be divers kinds of it, which I could name to you, but I will only tell you that that which is likest a buck's-horn is the best, except it be soft white moss, which grows on some heaths, and is hard to be found. And note, that in a very dry time, when you are put to an extremity for worms, walnut-tree leaves squeezed into water, or salt in water, to make it bitter or salt, and then that water poured on the ground, where you shall see worms are used to rise in the night, will make them to appear above ground presently. And you may take notice, some say that camphor, put into your bag with your moss and worms, gives them a strong and so tempting a smell, that the fish fare the worse and you the better for it.

* The following is also an excellent way, viz: Take a piece of hop-sack, or other very coarse cloth, and wash it clean, and let it dry ; then wet it in the liquor wherein beef has been boiled; but be careful that the beef is fresh, for salt will kill the worms, and wring it, but not quite dry ; put the worms into this cloth, and lay them in an earthen pot, and let them stand from morning till night; then take the worms from the cloth, and wash it, and wet it again in some of the liquor: do thus once a day, and you may keep worms in perfect health, and fit for use, for near a month.

Observe that the lob-worm, marsh-worm, and red-worm, will bear more scouring than any others, and are better for long keeping. $-\mathrm{H}$. 
And now I shall shew you how to bait your hook with a worm, so as shall prevent you from much trouble, and the loss of many a hook too, when you fish, for a trout with a running-line, ${ }^{*}$ that is to say, when you fish for him by hand at the ground: I will direct you in this as plainly as I can, that you may not mistake.

Suppose it be a big lob-worm, put your hook into him somewhat above the middle, and out again a little below the middle; having so done, draw your worm above the arming of your hook: but note that at the entering of your hook it must not be at the head-end of the worm, but at the tail-end of him, that the point of your hook may come out toward the head-end, and having drawn him above the arming of your hook, then put the point of your hook again into the very head of the worm, till it come near to the place where the point of the hook first came out; and then draw back that part of the worm that was above the shank or arming of your hook, and so fish with it. And if you mean to fish with two worms, then put the second on before you turn back the hook's head of the first worm: you cannot lose above two or three worms before you attain to what I direct you; and having attained it, you will find it very useful, and thank me for it, for you will run on the ground without tangling.

Now for the minnow or penk: he is not easily found and caught till March, or in April, for then he appears first in the river; nature having taught him to shelter and

- The running line, so called because it runs along the ground, is made of strong silk, which you may buy at the fishing-tackle shops (but I prefer hair, as being less apt to tangle), and is thus fitted up. About ten inches from the end, fasten a small cleft shot : then makc a hole through a pistol or musket bullet, according to the swiftness of the stream you fish in ; and put the line through it, and draw the bullet down to the shot ; to the end of your line fasten an Indian grass, or silkworm-gut, with a large hook. Or you may, instead of a bullet, fix four large shot, at the distance of eight inches from the hook. The running line is used for trout, grayling, and salmonsmelts; and is proper only for streams and rapid waters. See Cotton on Bottom-fishing, part ii. chap. xi.--H. 
hide himself, in the winter, in ditches that be near to the river; and there both to hide, and keep himself warm, in the mud, or in the weeds, which rot not so soon as in a running river, in which place if he were in winter, the distempered floods that are usually in that season would suffer him to take no rest, but carry him headlong to mills and weirs, to his confusion. And of these minnows; first you are to know that the biggest size is not the best; and next, that the middle size and the whitest are the best ; and then you are to know, that your minnow must be so put on your hook, that it must turn round when it is drawn against the stream; and, that it may turn nimbly, you must put it on a big-sized hook, as I shall now direct you, which is thus : put your hook in at his mouth and out at his gill; then, having drawn your hook two or three inches beyond or through his gill, put it again into his mouth, and the point and beard out at his tail; and then tie the hook and his tail about, very neatly, with a white thread, which will make it the apter to turn quick in the water : that done, pull back that part of your line which was slack when you did put your hook into the minnow the second time; I say, pull that part of your line back, so that it shall fasten the head, so that the body of the minnow shall be almost straight on your hook : this done, try how il will turn, by drawing it across the water or against a stream; and if it do not turn nimbly, then turn the tail a little to the right or left hand, and try again, till it turn quick; for if not, you are in danger to catch nothing: for know, that it is impossible that it should turn too quick; and you are yet to know, that in case you want a minnow, then a small loach or a stickle-bag, or any other small fish that will turn quick, will serve as well : and you are yet to know, that you may salt them, and by that means keep them ready and fit for use three or four days or longer; and that of salt, baysalt is the best. 
And here let me tell you, what many old anglers know right well, that at some times, and in some waters, a minnow is not to be got; and therefore let me tell you, I have,-which I will shew to you,-an artificial minnow,* that will catch a trout as well as an artificial fly, and it was made by a handsome woman that had a fine hand, and a live minnow lying by her : the mould or body of the minnow was cloth, and wrought upon or over it thus with a needle : the back of it with very sad French green silk, and paler green silk towards the belly, shadowed as perfectly as you can imagine, just as you see a minnow ; the belly was wrought also with a needle, and it was a part of it white silk, and another part of it with silver thread; the tail and fins were of a quill, which was shaven thin; the eyes were of two little black beads, and the head was so shadowed, and all of it so curiously wrought, and so exactly dissembled, that it would beguile any sharpsighted trout in a swift stream. And this minnow I will now shew you ; look, here it is, and, if you like it, lend it you, to have two or three made by it; for they be easily carried about an angler, and be of excellent use; for note, that a large trout will come as fiercely at a minnow as the highest mettled hawk doth seize on a partridge, or a greyhound on a hare. I have been told that a hundred and sixty minnows have been found in a trout's belly: either the trout had devoured so many, or the miller that gave it a friend of mine had forced them down his throat after he had taken him.

Now for flies, $\uparrow$ which is the third bait wherewith trouts are usually taken. You are to know that there are so

- Walton's method of making an artificial minnow is curious. How surprised he would be to see the artificial minnows, and other artificial fish baits of these days ! No amateur need make them now, as they are to be had cheaply at all the tackle shops, well made, and in infinite varicty. - E.

t The student must not pay any attention to what Walton says about artificial fiies. He was not a fly-fisher; but he was a good bottom-fisher, and dibbed or daped well.-E. 
many sorts of flies as there be of fruits : I will name you but some of them; as the dun-fly, the stone-fly, the redfly, the moor-fly, the tawny-fly, the shell-fly, the cloudy or blackish fly, the flag-fly, the vine-fly : there be of flies, caterpillars, and canker-flies, and bear-flies ; and indeed too many either for me to name, or for you to remember. And their breeding is so various and wonderful, that I might easily amaze myself, and tire you in a relation of them.

And, yet, I will exercise your promised patience by saying a little of the caterpillar, or the palmer-fly or worm ; that by them you may guess what a work it were, in a discourse, but to run over those very many flies, worms, and little living creatures, with which the sun and summer adorn and beautify the river-banks and meadows, both for the recreation and contemplation of us anglers ; pleasures which, I think, I myself enjoy more than any other man that is not of my profession.

Pliny holds an opinion, that many have their birth or being from a dew that in the spring falls upon the leaves of trees; and that some kinds of them are from a dew left upon herbs or flowers; and others, from a dew left upon coleworts or cabbages : all which kinds of dew being thickened and condensed, are by the sun's generative heat most of them hatched, and in three days made living creatures: and these of several shapes and colours; some being hard and tough, some smooth and soft; some are horned in their head, some in their tail, some have none; some have hair, some none; some have sixteen feet, some less, and some have none ; but as our Topsel * hath with great diligence observed, those which have none, move upon the earth, or upon broad leaves, their motion being not unlike the waves of the sea. Some of them, he also observes, to be bred of the eggs of other caterpillars, and that those in their time, turn to be butterflies; and

- In his History of Serpents. 
again, that their eggs turn the following year to be caterpillars. And some affirm, that every plant has his particular fly or caterpillar, which it breeds and feeds. I have seen, and may therefore affirm it, a green caterpillar, or worm, as big as a small peascod, which had fourteen legs, eight on the belly, four under the neck, and two near the tail. It was found on a hedge of privet and was taken thence, and put into a large box, and a little branch or two of privet put to it, on which I saw it feed as sharply as a dog gnaws a bone: it lived thus five or six days, and thrived, and changed the colour two or three times; but, by some neglect in the keeper of it, it then died, and did not turn to a fly : but if it had lived, it had doubtless turned to one of those flies that some call flies of prey, which those that walk by the rivers may, in summer, see fasten on smaller flies, and, I think, make them their food. And 'tis observable, that as there be these flies of prey, which be very large, so there be others, very little, created, I think, only to feed them, and breed out of I know not what; whose life, they say, nature intended not to exceed an hour; and yet that life is thus made shorter by other flies, or by accident.

It is needless to tell you what the curious searchers into nature's productions have observed of these worms and flies : but yet I shall tell you what Aldrovandus,* our Topsel, and others, say of the palmer-worm, or caterpillar, that whereas others content themselves to feed on particular herbs or leaves,-for most think those very leaves that gave them life and shape, give them a particular feeding and nourishment, and that upon them they usually abide ; yet he observes, that this is called a pilgrim, or palmerworm, for his very wandering life, and various food; not contenting himself, as others do, with any one certain

* Ulysses Aldrovandus, a great physician and naturalist of Bologna ; he wrote a hundred and twenty books on several subjects, and a treatise De Piscibus, published at Frankfort, 1640.-H. 
place for his abode, nor any certain kind of herb or flower for his feeding, but will boldly and disorderly wander up and down, and not endure to be kept to a diet, or fixed to a particular place.

Nay, the very colours of caterpillars are, as one has observed, very elegant and beautiful. I shall, for a taste of the rest, describe one of them; which I will, some time the next month, shew you feeding on a willow tree; and you shall find him punctually to answer this very description: his lips and mouth somewhat yellow; his eyes black as jet; his forehead purple; his feet and hinder parts green; his tail two-forked and black; the whole body stained with a kind of red spots, which run along the neck and shoulder-blade, not unlike the form of St. Andrew's cross, or the letter $\mathbf{X}$, made thus crosswise, and a white line drawn down his back to his tail; all which add much beauty to his whole body. And it is to me observable, that at a fixed age this caterpillar gives over to eat, and towards winter comes to be covered over with a strange shell or crust, called an aurelia : and so lives a kind of dead life, without eating, all the winter ; * and, as others of several kinds turn to be several kinds of flies and vermin the spring following, so this caterpillar then turns to be a painted butterfly.

Come, come, my scholar, you see the river stops our morning walk, and I will also here stop my discourse; only as we sit down under this honeysuckle hedge, whilst I look a line to fit the rod that our brother Peter hath lent you, I shall, for a little confirmation of what I have said, repeat the observation of Du Bartas.

God, not contented to each kind to give, And to infuse the virtue generative, By His wise power made many creatures breed Of lifeless bodies, without Venus' deed.

* See Sir Francis Bacon's Exper., 728 and 90, in his Natural History. $-\mathrm{H}$. 
So the cold humour breeds the salamander, Who, in effect, like to her birth's commander, With child with hundred winters, with her touch Quencheth the fire, though glowing ne'er so much.

So in the fire, in burning furnace, springs The fly Perausta, with the flaming wings ; Without the fire it dies, in it it joys, Living in that which all things else destroys.

So slow Boötes underneath him sees, In th' icy islands, goslings hatch'd of trees, Whose fruitful leaves, falling into the water, Are turn'd, 'tis known, to living fowls soon after.

So rotten planks of broken ships do change To barnacles. O transformation strange ! 'Twas first a green tree, then a broken hull, Lately a mushroom, now a flying gull.

VEN. O my good master, this morning-walk has been spent to my great pleasure and wonder : but I pray, when shall I have your direction how to make artificial flies, like to those that the trout loves best, and also how to use them ?

PIsc. My honest scholar, it is now past five of the clock, we will fish till nine, and then go to breakfast. Go you to yon sycamore-tree and hide your bottle of drink under the hollow root of it; for about that time, and in that place, we will make a brave breakfast with a piece of powdered beef, and a radish or two that I have in my fish-bag; we shall, I warrant you, make a good, honest, wholesome, hungry breakfast, and I will then give you direction for the making and using of your flies : and in the meantime, there is your rod and line, and my advice is, that you fish as you see me do, and let's try which can catch the first fish.

VEN. I thank you, master, I will observe and practise your direction as far as I am able. 
Pisc. Look you, scholar, you see I have hold of a good fish : I now see it is a trout, I pray put that net under him, and touch not my line, for if you do, then we break all.* Well done, scholar, I thank you.

Now for another. Trust me, I have another bite : come, scholar, come lay down your rod, and help me to land this as you did the other. So now we shall be sure to have a good dish for supper.

Ven. I am glad of that: but I have no fortune: sure, master, yours is a better rod and better tackling.

PIsc. Nay, then, take mine ; and I will fish with yours. Look you, scholar, I have another. Come, do as you did before. And now I have a bite at another. Oh me! he has broke all: there's half a line and a good hook lost.

Ven. Ay, and a good trout too.

PIsc. Nay, the trout is not lost; for pray take notice, no man can lose what he never had.

Ven. Master, I can neither catch with the first nor second angle: I have no fortune.

Pisc. Look you, scholar, I have yet another. And now, having caught three [two] brace of trouts, I will tell you a short tale as we walk towards our breakfast. A scholar, a preacher I should say, that was to preach to procure approbation of a parish that he might be their lecturer, had got from his fellow pupil the copy of a sermon that was first preached with great commendation by him that composed it : and though the borrower of it preached it, word for word, as it was at first, yet it was utterly disliked as it was preached by the second to his congregation: which the sermon-borrower complained of to the lender of it: and thus was answered: "I lent you, indeed, my fiddle, but not my fiddle-stick; for you are

* Nothing can be sounder than this advice. In playing a fish, the line must never be seized by the hand, but it must be shortened more or less according to circumstances, by winding it up by means of the winch or reel.-E. 
to know, that every one cannot make music with my words, which are fitted to my own mouth." And so, my scholar, you are to know, that as the ill pronunciation or ill accenting of words in a sermon spoils it, so the ill carriage of your line, or not fishing even to a foot in a right place, makes you lose your labour : and you are to know, that though you have my fiddle, that is, my very rod and tacklings with which you see I catch fish, yet you have not my fiddlestick, that is, you yet have not skill to know how to carry your hand and line, nor how to guide it to a right place : and this must be taught you : for you are to remember, I told you angling is an art, either by practice or a long observation, or both. But take this for a rule, When you fish for a trout with a worm, let your line have so much, and not more lead than will fit the stream in which you fish; that is to say, more in a great troublesome stream than in a smaller that is quieter; as near as may be, so much as will sink the bait to the bottom, and keep it still in motion, and not more.

But now let's say grace and fall to breakfast : what say you, scholar, to the providence of an old angler? Does not this meat taste well? and was not this place well chosen to eat it? for this sycamore-tree will shade us from the sun's heat.

VEN. All excellent good, and my stomach excellent good too. And now I remember and find that true which devout Lessius * says : " That poor men, and those that fast often, have much more pleasure in eating than rich men and gluttons, that always feed before their stomachs are empty of their last meat, and call for more : for by

* Leonard Lessius, a very learned Jesuit, professor of divinity in the College of Jesuits at Louvain. He was born at Antwerp, 1554, and became very famous for his skill in divinity, civil law, mathematics, physic, and history: he wrote several theological tracts, and a book entitled, Hygiasticon, seu vera ratio valetudinis honae, et vilae ad extremam senectutem conservandae. From this work of Lessius, it is probable the passage in the text is cited. He died 1623. 
that means they rob themselves of that pleasure that hunger brings to poor men." And I do seriously approve of that saying of yours, " that you would rather be a civil, well-governed, well-grounded, temperate, poor angler, than a drunken lord." $\quad$ But I hope there is none such ; however, I am certain of this, that I have been at many very costly dinners that have not afforded me half the content that this has done, for which I thank God and you.

And now, good master, proceed to your promised direction for making and ordering my artificial fly.

Pisc. My honest scholar, I will do it; for it is a debt due unto you by my promise. And because you shall not think yourself more engaged to me than indeed you really are, I will freely give you such directions as were lately given to me by an ingenious brother of the angle, an honest man, and a most excellent fly-fisher.*

You are to note, that there are twelve kinds of artificial made flies, to angle with upon the top of the water. Note, by the way, that the fittest season of using these, is a blustering windy day, when the waters are so troubled, that the natural fly cannot be seen, or rest upon them. The first, is the dun-fly, in March : the body is made of dun wool; the wings, of the partridge's feathers. The second, is another dun-fly; the body of black wool : and the wings made of the black drake's feathers, and of the feathers under his tail. The third, is the stone fly, in April : the body is made of black wool ; made yellow under the wings and under the tail, and so made with wings of the drake. The fourth, is the ruddy-fly, in the beginning of May: the body made of red wool, wrapt about with black silk; and the feathers are the wings of the drake: with the feathers of a red , * Walton knew very little about fly-fishing. In this passage he admits his ignorance, by stating that the instructions he gives the scholar are derived from " an ingenious brother of the angle." The instructions are curious, but by no means useful.-E. 
capon also, which hangs dangling on his sides next to the tail. The fifth, is the yellow or greenish fly, in May likewise : the body made of yellow wool ; and the wings made of the red cock's hackle or tail. The sixth, is the black-fly, in May also: the body made of black wool, and lapped about with the herle of a peacock's tail : the wings are made of the wings of a brown capon, with his blue feathers in his head. The seventh, is the sad yellow-fly, in June: the body is made of black wool, with a yellow list on either side; and the wings taken off the wings of a buzzard, bound with black braked hemp. The eighth, is the moorish-fly; made with the body of duskish wool; and the wings made of the blackish mail of the drake. The ninth, is the tawny fly, good until the middle of June: the body made of tawny wool, the wings made contrary, one against the other, made of the whitish mail of the wild drake. The tenth, is the wasp-fly, in July; the body made of black wool, lapped about with yellow silk, the wings made of the feathers of the drake, or of the buzzard. The eleventh, is the shell-fly, good in mid-July; the body made of greenish wool, lapped about with the herle of a peacock's tail, and the wings made of the wings of the buzzard. The twelfth, is the dark drake-fly, good in August; the body made with black wool, lapped about with black silk; his wings are made with the mail of the black drake, with a black head. Thus have you a jury of flies, likely to betray and condemn all the trouts in the river.*

I shall next give you some other directions for fly-fishing, such as are given by Mr. Thomas Barker, a gentleman that hath spent much time in fishing; but I shall do it with a little variation.

* The reader is not to adopt for his use any of these flies. By the word " mail," we must understand "mottled." The mottled feathers of the mallard of several hues are still used for the wings, legs, and tails of flies. There are few feathers more useful.-E. 
First, let your rod be light, and very gentle; I take the best to be of two pieces: and let not your line exceed,-especially for three or four links next to the hook,-I say, not exceed three or four hairs at the most, though you may fish a little stronger above, in the upper part of your line; but if you can attain to angle with one hair, you shall have more rises, and catch more fish. Now you must be sure not to cumber yourself with too long a line, as most do. And before you begin to angle, cast to have the wind on your back; and the sun, if it shines, to be before you ; and to fish down the stream; and carry the point or top of your rod downward, by which means, the shadow of yourself and rod too, will be least offensive to the fish; for the sight of any shade amazes the fish, and spoils your sport-of which you must take a great care.

In the middle of March, till which time, a man should not, in honesty, catch a trout-or in April, if the weather be dark, or a little windy or cloudy, the best fishing is with the palmer-worm, of which I last spoke to you ; but of these there be divers kinds, or at least of divers colours : these and the May-fly are the ground of all fly-angling, which are to be thus made :

First, you must arm your hook with the line in the inside of it, then take your scissors, and cut so much of a brown mallard's feather, as in your own reason will make the wings of it, you having withal regard to the bigness or littleness of your hook; then lay the outmost part of your feather next to your hook, then the point of your feather next the shank of your hook ; and having so done, whip it three or four times about the hook with the same silk with which your hook was armed; and, having made the silk fast, take the hackle of a cock or capon's neck, or a plover's top, which is usually better; take off the one side of the feather, and then take the hackle, silk, or crewel, gold or silver 
thread, make these fast at the bent of the hook, that is to say, below your arming; then you must take the hackle, the silver or gold thread, and work it up to the wings, shifting or still removing your finger, as you turn the silk about the hook; and still looking at every stop or turn, that your gold, or what materials soever you make your fly of do lie right and neatly; and if you find they do so, then, when you have made the head, make all fast; and then work your hackle up to the head, and make that fast: and then with a needle or pin divide the wing into two, and then with the arming silk whip it about crossways betwixt the wings, and then with your thumb you must turn the point of the feather towards the bent of the hook, and then work three or four times about the shank of the hook, and then view the proportion, and if all be neat and to your liking, fasten.

I confess, no direction can be given to make a man of a dull capacity able to make a fly well : and yet I know, this, with a little practice, will help an ingenious angler in a good degree; but to see a fly made by an artist in that kind, is the best teaching to make it. And then an ingenious angler may walk by the river and mark what flies fall on the water that day, and catch one of them, if he sees the trouts leap at a fly of that kind; and then having always hooks ready hung with him, and having a bag also always with him, with bear's hair, or the hair of a brown or sad-coloured heifer, hackles of a cock or capon, several coloured silk and crewel to make the body of the fly, the feathers of a drake's head, black or brown sheep's wool, or hog's wool or hair, thread of gold and of silver ; silk of several colours (especially sad-coloured), to make the fly's head: and there be also other coloured feathers, both of little birds and of speckled fowl: I say, having those with him in a bag, and trying to make a fly, though he miss at 
first, yet shall he at $t_{1}$ last hit it better, even to such a perfection as none can well teach him; and if he hit to make his fly right, and have the luck to hit also where there is store of trouts, a dark day, and a right wind, he will catch such store of them, as will encourage him to grow more and more in love with the art of fly-making.

VEN. But, my loving master, if any wind will not serve, then I wish I were in Lapland, to buy a good wind of one of the honest witches, that sell so many winds there, and so cheap.

Pisc. Marry, scholar, but I would not be there, nor indeed from under this tree: for look how it begins to rain; and by the clouds, if I mistake not, we shall presently have a smoking shower; and therefore sit close; this sycamore tree will shelter us : and I will tell you, as they shall come into my mind, more observations of fly-fishing for a trout.

But first, for the wind: you are to take notice, that of the winds, the south wind is said to be the best. One observes, that

... when the wind is south,

It blows your bait into a fish's mouth.

Next to that, the west wind is believed to be the best : and having told you that the east wind is the worst, I need not tell you which wind is the best in the third degree : and yet (as Solomon observes), that "he that considers the wind shall never sow;" so he that busies his head too much about them, if the weather be not made extreme cold by an east wind, shall be a little superstitious : for as it is observed by some, that " there is no good horse of a bad colour," so I have observed, that if it be a cloudy day, and not extreme cold, let the wind set in what corner it will and do its worst, I heed it not. And yet take this for a rule, that I would willingly fish, standing on the lee-shore: and you are to take notice, that the fish lies or swims nearer the bottom, 
and in deeper water, in winter than in summer; and also nearer the bottom in any cold day, and then gets nearest the lee side of the water.

But I promised to tell you more of the fly-fishing for a trout, which I may have time enough to do, for you see it rains May-butter. First, for a May-fly, you may make his body with greenish-coloured crewel or willowish colour; darkening it in most places with waxed silk, or ribbed with black hair, or some of them ribbed with silver thread; and such wings for the colour, as you see the fly to have at that season, nay, at that very day, on the water. Or you may make the oak-fly, with an orange tawny, and black ground, and the brown of a mallard's feather for the wings; and you are to know, that these two are most excellent flies, that is, the May-fly and the oak-fly. And let me again tell you that you keep as far from the water as you can possibly, whether you fish with a fly or worm, and fish down the stream : and when you fish with a fly, if it be possible, let no part of your line touch the water,* but your fly only; and be still moving your fly upon the water, or casting it into the water, you yourself being also always moving down the stream.

Mr. Barker commends several sorts of the palmer-flies, not only those ribbed with silver and gold, but others that have their bodies all made of black, or some with red, and a red hackle; you may also make the hawthornfly, which is all black, and not big, but very small, the smaller the better; or the oak-fly, the body of which is orange colour and black crewel, with a brown wing; or a fly made with a peacock's feather is excellent in a bright day. You must be sure you want not in your magazine bag, the peacock's feather, and grounds of such wool and crewel as will make the grasshopper; and note,

- This is impossible, unless you dib with the artifncial as with the natural fly, which is never practised.-E. 
that usually the smallest flies are the best; and note also, that the light fly does usually make most sport in a dark day, and the darkest and least fly in a bright or clear day; and lastly, note, that you are to repair upon any occasion to your magazine-bag, and upon any occasion, vary and make them lighter or sadder, according to your fancy, or the day.

And now I shall tell you, that the fishing with a natural fly is excellent, and affords much pleasure. They may be found thus : the May-fly, usually in and about that month, near to the river side, especially against rain: the oak-fly, on the butt or body of an oak or ash, from the beginning of May to the end of August ; it is a brownish fly and easy to be found, and stands usually with his head downward, that is to say, towards the root of the tree : the small black fly, or hawthorn-fly, is to be had on any hawthorn bush after the leaves be come forth. With these and a short line (as I shewed, to angle for a chub), you may dape or dop, and also with a grasshopper, behind a tree, or in any deep hole; still making it to move on the top of the water, as if it were alive, and still keeping yourself out of sight, you shall certainly have sport if there be trouts; yea, in a hot day, but especially in the evening of a hot day, you will have sport.

And now, scholar, my direction for fly-fishing is ended with this shower, for it has done raining; and now look about you, and see how pleasantly that meadow looks; nay, and the earth smells as sweetly too. Come, let me tell you what holy Mr. Herbert says of such days and flowers as these; and then we will thank God that we enjoy them, and walk to the river and sit down quietly, and try to catch the other brace of trouts.

Sweet day, so cool, so calm, so bright, The bridal of the earth and sky, Sweet dews shall weep thy fall to-night-

For thou must die. 
Sweet rose, whose hue, angry and brave, Bids the rash gazer wipe his eye, Thy root is ever in its grave-

And thou must die.

Sweet spring, full of sweet days and roses, A box where sweets compacted lie; My music shows you have your closesAnd all must die.

Only a swect and virtuous soul, Like season'd timber, never gives; But when the whole world turns to coal, Then chiefly lives.

VEN. I thank you, good master, for your good direction for fly-fishing, and for the sweet enjoyment of the pleasant day, which is so far spent without offence to God or man : and I thank you for the sweet close of your discourse with Mr. Herbert's verses, who, I have heard, loved angling; and I do the rather believe it, because he had a spirit suitable to anglers, and to those primitive Christians that you love, and have so much commended.

Pisc. Well, my loving scholar, and I am pleased to know that you are so well pleased with my direction and discourse.

And since you like these verses of Mr. Herbert's so well, let me tell you what a reverend and learned divine that professes to imitate him (and has indeed done so most excellently), hath writ of our book of Common Prayer ; which I know you will like the better, because he is a friend of mine, and I am sure no enemy to angling.

What! Prayer by the Book? and Common? Yes ! why not?

The spirit of grace And supplication

Is not left free alone

For time and place,

But manner too: to read, or speak, by rote, Is all alike to him that prays

In 's heart, what with his mouth he says. 
They that in private, by themselves alone,

Do pray, may take

What liberty they please,

In choosing of the ways

Wherein to make

Their soul's most intimate affections known

To Him that sees in secret, when

They're most conceal'd from other men.

But he that unto others leads the way

In public prayer,

Should do it so

As all that hear may know

They need not fear

To tune their hearts unto his tongue, and say,

Amen; not doubt they were betray'd

To blaspheme, when they meant to have pray'd.

Devotion will add life unto the letter:

And why should not

That which authority

Prescribes, esteemed be

Advantage got?

If the prayer be good, the commoner the better ;

Prayer in the Church's words as well

As sense, of all prayers bears the bell.-Ch. Harvie.

And now, scholar, I think it will be time to repair to our angle-rods, which we left in the water, to fish for themselves : and you shall choose which shall be yours; and it is an even lay, one of them catches.

And, let me tell you, this kind of fishing with a dead rod, and laying night-hooks, are like putting money to use ; for they both work for the owners, when they do nothing but sleep, or eat, or rejoice; as you know we have done this last hour, and sat as quietly and as free from cares under this sycamore, as Virgil's Tityrus and his Melibœus did under their broad beech-tree. No life, my honest scholar, no life so happy and so pleasant, as the life of a well-governed angler, for when the lawyer is swallowed up with business, and the statesman is preventing or con- 
triving plots, then we sit on cowslip-banks, hear the birds sing, and possess ourselves in as much quietness as these silent silver streams, which we now see glide so quietly by us. Indeed, my good scholar, we may say of angling, as Dr. Boteler said of strawberries, "Doubtless God could have made a better berry, but doubtless God never did : " and so, if I might be judge, " God never did make a more calm, quiet, innocent recreation, than angling."

I'll tell you, scholar, when I sat last on this primrosebank, and looked down these meadows, I thought of them, as Charles the emperor did of the city of Florence, " That they were too pleasant to be looked on, but only on holidays." As I then sat on this very grass, I turned my present thoughts into verse: 'twas a wish, which I'll repeat to you.*

\section{Tbe Anter's Taisb}

I in these flowery meads would be :

These crystal streams should solace me ;

To whose harmonious bubbling noise

I with my angle would rejoice,

Sit here, and see the turtle-dove

Court his chaste mate to acts of love :

Or, on that bank, feel the west wind Breathe health and plenty; please my mind, To see sweet dewdrops kiss these flowers, And then wash'd off by April showers;

Here, hear my Kenna $\uparrow$ sing a song ; a There, see a blackbird feed her young,

[a "Like Hermit Poor."]

* We have here little less than Walton's own word for it, that the following beautiful stanzas are of his writing. That he had in his mind a vein of poctry is noted in our life of him ; to which let me add, that the name of his supposed mistress, " Kenna," seems clearly to be formed from the maiden-name of his wife, which was Ken.-H. $\dagger$ We see, by the author's reference to the margin, that he wishes to hear Kenna, his mistress, sing the song, "Like Hermit Poor." This song was set to music by Nich. Laneare, an eminent master of Walton's time.

There is no doubt that this song was (and probably with Mrs. 
Or a leverock build her nest :

Here, give my weary spirits rest, And raise my low-pitch'd thoughts above

Earth, or what poor mortals love :

Thus, free from lawsuits and the noise

Of princes' courts, I would rejoice ;

Or, with my Bryan * and a book, Loiter long days near Shawford brook ; $\dagger$ There sit by him, and eat my meat; There see the sun both rise and set; There bid good morning to next day;

There meditate my time away; And angle on, and beg to have A quiet passage to a welcome grave.

When I had ended this composure, I left this place, and saw a brother of the angle sit under that honeysuckle hedge, one that will prove worth your acquaintance: I sat down by him, and presently we met with an accidental piece of merriment, which I will relate to you; for it rains still.

On the other side of this very hedge sat a gang of gipsies, and near to them sat a gang of beggars. The gipsies were then to divide all the money that had been got that week, either by stealing linen or poultry, or by fortune-telling, or legerdemain, or indeed by any other sleights and secrets belonging to their mysterious govern-

Walton) a favourite one; for, some years after the Restoration, the three first words of it were become a phrase. The affected writer of the Life of the Lord Keeper Guildford, page 212 of that book, speaking of Sir Job Charleton, then chief-justice of Chester, says, he wanted to speak with the king ; and went to Whitehall ; where, returning from his walk in St. James's Park, he must pass : and there he sat him down " like hermit poor."-H.

* A friend conjectures this to be the name of his favourite dog.-H.

t Shawford Brook, part of the River Sow, running through the very land which Walton bequeathed in his will to the corporation of Stafford to find coals for the poor: the right of fishery in which attaches to this little estate. The house, described by Walton in his will, is now divided. The brook is a beautiful winding stream, and the situation such as would be likely to create admiration in a mind like Walton's.-H. 
ment. And the sum that was got that week proved to be but twenty and some odd shillings. The odd money was agreed to be distributed amongst the poor of their own corporation; and for the remaining twenty shillings, that was to be divided unto four gentlemen gipsies, according to their several degrees in their commonwealth.

And the first or chiefest gipsy was, by consent, to have a third part of the 20s., which all men know is $6 s .8 d$.

The second was to have a fourth part of the 20 s., which all men know to be 5 s.

The third was to have a fifth part of the 20 s., which all men know to be $4 s$.

The fourth and last gipsy was to have a sixth part of the 20 s., which all men know to be $3 s .4 d$.

As for example,

3 times $6 s .8 d$. is 20 s.

And so is 4 times 5 s. . 20 s.

And so is 5 times $4 s$. . $20 s$.

And so is 6 times 3s. 4 d. . 20 s.

And yet he that divided the money was so very a gipsy, that though he gave to every one these said sums, yet he kept 1 s. of it for himself.

$\begin{array}{lrl}\text { As for example, } & s . & d . \\ 6 & 8 \\ 5 & 0 \\ 4 & 0 \\ & 3 & 4 \\ & \\ \text { make but . } & 19 & 0\end{array}$

But now you shall know, that when the four gipsies saw that he had got 1s. by dividing the money, though not one of them knew any reason to demand more, yet, like lords and courtiers, every gipsy envied him that was the gainer, and wrangled with him, and every one said the remaining shilling belonged to him : and so they fell 
to so high a contest about it, as none that knows the faithfulness of one gipsy to another will easily believe; only we that have lived these last twenty years, are certain that money has been able to do much mischief. However, the gipsies were too wise to go to law, and did therefore choose their choice friends Rook and Shark, and our late English Gusman,* to be their arbitrators and umpires; and so they left this honeysuckle hedge, and went to tell fortunes, and cheat, and get more money and lodging in the next village.

When these were gone, we heard a high contention amongst the beggars, whether it was easiest to rip a cloak, or to unrip a cloak. One beggar affirmed it was all one. But that was denied by asking her if doing and undoing were all one. Then another said 'twas easiest to unrip a cloak, for that was to let it alone. But she was answered, by asking her, how she unripped it, if she let it alone : and she confessed herself mistaken. These and twenty such like questions were proposed, and answered with as much beggarly logic and earnestness, as was ever heard to proceed from the mouth of the most pertinacious schismatic : and sometimes all the beggars, whose number was neither more nor less than the poet's nine muses, talked altogether about this ripping and unripping, and so loud that not one heard what the other said: but at last one beggar craved audience, and told them, that old father Clause, whom Ben Jonson in his Beggar's Bush, $\dagger$ created king of their corporation, was to lodge at an alehouse called "Catch-her-by-the-way," not far from Waltham Cross,

* Alluding to a work that appeared a few years before, entitled The English Gusman, or, The History of that Unparalleled Thief, James Hind, written by George Fidge, 4to, London, 1652. Hind made a considerable figure at the time of the great rebellion, and fought, both at Worcester and Warrington, on the king's side. He was arrested by order of the Parliament in 1651. Rook and Shark, imaginary associates of the "English Gusman."- $-\mathrm{H}$.

$\dagger$ This comedy was not written by Jonson, but by Beaumont and Fletcher. 
and in the high road towards London; and he therefore desired them to spend no more time about that and such like questions, but refer all to father Clause at night, for he was an upright judge, and in the meantime draw cuts, what song should be next sung, and who should sing it. They all agreed to the motion; and the lot fell to her that was the youngest and veriest virgin of the company. And she sung Frank Davison's song, which he made forty years ago ; and all the others of the company joined to sing the burthen with her. The ditty was this : but first the burthen:

Bright shines the sun; play, beggars, play! Here's scraps enough to serve to-day.

What noise of viols is so sweet,

As when our merry clappers ring ?

What mirth doth want when beggars meet ?

A beggar's life is for a king.

Eat, drink, and play, sleep when we list,

Go where we will-so stocks be miss'd.

Bright shines the sun; play, beggars, play !

Here's scraps enough to serve to-day.

The world is ours, and ours alone ;

For we alone have world at will.

We purchase not-all is our own ;

Both fields and streets we beggars fill.

Bright shines the sun ; play, beggars, play!

Here's scraps enough to serve to-day.

A hundred herds of black and white

Upon our gowns securely feed ;

And yet if any dare us bite,

He dies, therefore, as sure as creed.

Thus beggars lord it as they please,

And only beggars live at ease.

Bright shines the sun; play, beggars, play!

Here's scraps enough to serve to-day.

VEN. I thank you, good master, for this piece of 
merriment, and this song, which was well humoured by the maker, and well remembered by you.

PIsc. But, I pray, forget not the catch which you promised to make against night; for our countryman, honest Coridon, will expect your catch, and my song, which I must be forced to patch up, for it is so long since I learnt it, that I have forgotten a part of it. But, come, now it hath done raining, let's stretch our legs a little in a gentle walk to the river, and try what interest our angles will pay us for lending them so long to be used by the trouts ; lent them, indeed, like usurers, for our profit and their destruction.

Ven. Oh me! look you, master, a fish ! a fish ! Oh, alas, master, I have lost her!

Pisc. Ay, marry, sir, that was a good fish indeed: if I had had the luck to have taken up that rod, then 'tis twenty to one he should not have broke my line by running to the rod's end, as you suffered him. I would have held him within the bent of my rod (unless he had been fellow to the great trout that is near an ell long, which was of such a length and depth that he had his picture drawn, and now is to be seen at mine host Rickabie's, at the "George," in Ware), and it may be by giving that very great trout the rod, that is, by casting it to him into the water, I might have caught him at the long run; for so I use always to do when I meet with an overgrown fish; and you will learn to do so too hereafter: for I tell you, scholar, fishing is an art; or, at least, it is an art to catch fish.

VEN. But, master, I have heard that the great trout you speak of is a salmon.

PIsc. Trust me, scholar, I know not what to say to it. There are many country people that believe hares change sexes every year : and there be very many learned men think so too, for in their dissecting them they find many reasons to incline them to that belief. And to 
make the wonder seem yet less, that hares change sexes, note, that Doctor Mer. Casaubon affirms in his book of credible and incredible things, that Gaspar Peucerus, a learned physician, tells us of a people that once a year turn wolves, partly in shape, and partly in conditions. And so, whether this were a salmon when he came into the fresh water, and his not returning into the sea hath altered him to another colour or kind, I am not able to say : but I am certain he hath all the signs of being a trout both for his shape, colour, and spots; and yet many think he is not.

VeN. But, master, will this trout which I had hold of die? for it is like he hath the hook in his belly.

Pisc. I will tell you, scholar, that unless the hook be fast in his very gorge, 'tis more than probable he will live ; and a little time, with the help of the water, will rust the hook, and it will in time wear away ; as the gravel doth in the horse-hoof, which only leaves a false quarter.

And now, scholar, let's go to my rod. Look you, scholar, I have a fish too, but it proves a logger-headed chub; and this is not much amiss, for this will pleasure some poor body, as we go to our lodging to meet our brother Peter and honest Coridon. Come, now bait your hook again, and lay it into the water, for it rains again : and we will even retire to the sycamore tree, and there I will give you more directions concerning fishing; for I would fain make you an artist.

VEN. Yes, good master, I pray let it be so.

Pisc. Well, scholar, now we are sat down and are at ease, I shall tell you a little more of trout fishing, before I speak of salmon, which I purpose shall be next, and then of the pike or luce.

You are to know there is night as well as day-fishing for a trout, and that in the night the best trouts come out of their holes : and the manner of taking them is, on the top of the water, with a great lob or garden-worm, or rather 
two, which you are to fish with in a place where the waters run somewhat quietly, for in a stream the bait will not be so well discerned. I say, in a quiet or dead place, near to some swift: there draw your bait over the top of the water, to and fro ; and if there be a good trout in the hole, he will take it, especially if the night be dark; for then he is bold, and lies near the top of the water, watching the motion of any frog, or water-rat, or mouse, that swims between him and the sky : these he hunts after if he sees the water but wrinkle or move in one of these dead holes, where these great old trouts usually lie near to their holds; for you are to note, that the great old trout is both subtle and fearful, and lies close all day, and does not usually stir out of his hold, but lies in it as close in the day as the timorous hare does in her form, for the chief feeding of either is seldom in the day, but usually in the night, and then the great trout feeds very boldly.

And you must fish for him with a strong line, and not a little hook; and let him have time to gorge your hook, for he does not usually forsake it, as he oft will in the day-fishing. And if the night be not dark, then fish so with an artificial fly of a light colour, and at the snap : nay, he will sometimes rise at a dead mouse, or a piece of cloth, or anything that seems to swim across the water, or to be in motion. This is a choice way, but I have not often used it, because it is void of the pleasures that such days as these, that we two now enjoy, afford an angler.

And you are to know, that in Hampshire, which I think exceeds all England for swift, shallow, clear, pleasant brooks, and store of trouts, they used to catch trouts in the night, by the light of a torch or straw, which, when they have discovered, they strike with a trout-spcar, or oiher ways. This kind of way they catch very many; but I would not believe it till I was an eye-witness of it, nor do I like it now I have seen it.

VEN. But, master, do not trouts see us in the night? 
Pisc. Yes, and hear and smell too, both then and in the day-time : for Gesner observes, the otter smells a fish forty furlongs off him in the water : and that it may be true, seems to be affirmed by Sir Francis Bacon, in the eighth century of his Natural History, who there proves that waters may be the medium of sounds, by demonstrating it thus : " that if you knock two stones together very deep under the water, those that stand on a bank near to that place may hear the noise without any diminution of it by the water." He also offers the like experiment concerning the letting an anchor fall, by a very long cable or rope, on a rock, or the sand within the sea. And this being so well observed and demonstrated as it is by that learned man, has made me to believe that eels unbed themselves and stir at the noise of thunder; and not only, as some think, by the motion or stirring of the earth, which is occasioned by that thunder.

And this reason of Sir Francis Bacon (Exper. 792) has made me crave pardon of one that I laughed at, for affirming, that he knew carps come to a certain place in a pond, to be fed, at the ringing of a bell, or the beating of a drum : and however, it shall be a rule for me to make as little noise as I can when I am fishing, until Sir Francis Bacon be confuted, which I shall give any man leave to do.*

* That fish hear, is confirmed by the authority of other writers. Swammerdam asserts it, and adds, that " they have a wonderful labyrinth of the ear for that purpose." See Swammerdam on Insects, edit. London, 1758 , p. 50 . A clergyman, a friend of mine, assures me, that at the Abbey of St. Bernard, near Antwerp, he saw carp come at the whistling of the feeder.-H.

With respect to the organs of hearing, and the power of hearing in fish, I consulted Mr. Erasmus Wilson, one of the most eminent anatomists and physiologists, and the following is his opinion :"There is nothing in the exterior head of the fish to indicate that it is provided with an ear. In the higher animals, the mechanical apparatus of hearing consists of an internal and an external portion : in fishes, the internal portion alone exists, and is hardly inferior in perfection of form and structure, to that of creatures placed higher in the animal scale. The nerves distributed to the organs of hearing are of large size, and the vital apparatus, or portion 
And, lest you may think him singular in his opinion, I will tell you, this seems to be believed by our learned Doctor Hakewill, who, in his apology of God's power and providence (fol. 360), quotes Pliny to report, that one of the emperors had particular fish-ponds, and in them several fish that appeared and came when they were called by their particular names : and St. James tells us (chap. iii., 7) that all things in the sea have been tamed by mankind. And Pliny tells us (lib. ix., 35) that Antonia, the wife of Drusus, had a lamprey, at whose gills she hung jewels or ear-rings; and that others have been so tender-hearted as to shed tears at the death of fishes which they have kept and loved. And these observations, which will to most hearers seem wonderful,

of brain, from which the former proceed, is considerable: There exists, however, this important difference between the organ of hearing of terrestrial animals and fishes, viz., that the ear in the former is organised for the reception of the more delicate vibrations of the atmosphere, while in the latter it is adapted to the rude oscillations of a denser element. We may make this difference apparent by the following simple illustration. The impulse occasioned to the air by the ticking of a watch is so weak, as to be indistinctly heard when the watch is brought close to the ear; but if we convey the watch to a greater distance from the ear and press it against the teeth, we hear the ticking with remarkable distinctness. In the language of science, solid and dense bodies vibrate with greater intensity than lighter media, such as the atmosphere. When the watch is held nigh to the ear, the atmosphere is the conductor; when the watch is connected with the ear by the intervention of a rod of wood, or the solid parts of the head, these are the conductors. Now the apparatus of hearing of the fish presents conductors of the latter kind; water, a denser body than air, is the conducting medium ; and the solid mass of the head, and, in fact, of the entire body, complete the conduction to the vital apparatus. Hence, in fishes, an humble contrivance is capable of effecting the same end as the higher-toned instruments of terrestrial animals. As fishes thus evidently possess the organ of hearing in a moderate degree of perfection, they must therefore hear with moderate acutencss, particularly such sounds as occasion a vibration of the element in which they reside; for example, an approaching footstep; while the sounds which proceed from musical instruments, being less easily conveyed, are probably unknown to them : certainly this is the case with regard to tone." We constantly hear of fish coming to be fed at the sound of the bell. They rather come to the sound of the bell-ringer's feet, that is to the vibration caused by his footfall, and so indicating his presence.-E. 
seem to have a further confirmation from Martial (lib. iv., Epigr. 30), who writes thus :

\section{Piscator, fuge; ne nocens, elc.}

Angler! wouldst thou be guiltless? then forbear; For these are sacred fishes that swim here,

Who know their sovereign, and will lick his hand; Than which none's greater in the world's command : Nay more, they've names, and, when they called are, Do to their several owner's call repair.

All the further use that I shall make of this, shall be, to advise anglers to be patient and forbear swearing, lest they be heard, and catch no fish.

And so I shall proceed next to tell you, it is certain, that certain fields near Leominster, a town in Herefordshire, are observed to make the sheep that graze upon them more fat than the next, and also to bear finer wool ; that is to say, that that year in which they feed in a such particular pasture, they shall yield finer wool than they did that year before they came to feed in it, and coarser again if they shall return to their former pasture ; and again return to a finer wool, being fed in the fine-wool ground. Which I tell you, that you may the better believe, that I am certain, if I catch a trout in one meadow he shall be white and faint, and very like to be lousy; and as certainly, if $I$ catch a trout in the next meadow, he shall be strong, and red, and lusty, and much better meat. Trust me, scholar, I have caught many a trout in a particular meadow, that the very shape and the enamelled colour of him hath been such, as have joyed me to look on him : and I have then with much pleasure concluded with Solomon, "Everything is beautiful in his season."

I should by promise speak next of the salmon; but I will by your favour say a little of the umber or grayling, which is so like a trout for his shape and feeding, that I desire I may exercise your patience with a short discourse of him, and then the next shall be of the salmon. 


\section{CHAPTER VI}

OBSERVATIONS OF THE UMBER OR GRAYLING, AND DIRECTIONS HOW TO FISH FOR HIM

\section{[jourtb Day]}

PISc. The Umber and Grayling are thought by some to differ, as the herring and pilchard do. But though they may do so in other nations, I think those in England differ in nothing but their names. Aldrovandus says, they be of a trout kind; and Gesner says, that in his country, which is in Switzerland, he is accounted the choicest of all fish. And in Italy, he is in the month of May, so highly valued, that he is sold at a much higher rate than any other fish. The French, which call the chub un vilain, call the umber of the Lake Leman un umble chevalier: and they value the umber or grayling so highly that they say he feeds on gold-and say, that many have been caught out of their famous River Loire, out of whose bellies grains of gold have been often taken. And some think that he feeds on water-thyme, and smells of it at his first taking out of the water; and they may think so with as good reason as we do that our smelts smell like violets at their first being caught, which I think is a truth. Aldrovandus says, the salmon, the grayling, and trout, and all fish that live in clear and sharp streams, are made by their mother nature of such exact shape and pleasant colours purposely to invite us to a joy and contentedness in feasting with her. Whether this is a truth or not it is not my purpose to dispute : but 'tis certain, all that write of the umber 
declare him to be very medicinable. And Gesner says, that the fat of an umber or grayling, being set, with a little honey, a day or two in the sun, in a little glass, is very excellent against redness, or swarthiness, or anything that breeds in the eyes. Salvian takes him to be called umber from his swift swimming, or gliding out of sight more like a shadow or a ghost than a fish. Much more might be said both of his smell and taste: but I shall only tell you, that St. Ambrose, the glorious bishop of Milan, who lived when the Church kept fasting days, calls him the flower-fish, or flower of fishes; and

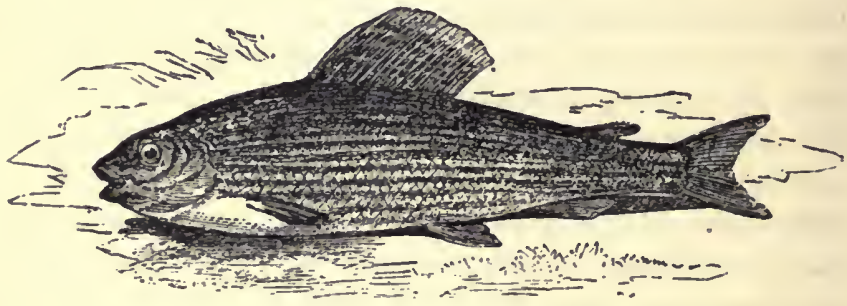

GRAYLING

that he was so far in love with him that he would not let him pass without the honour of a long discourse; but I must, and pass on to tell you how to take this dainty fish.

First, note, that he grows not to the bigness of a trout; for the biggest of them do not usually exceed eighteen inches. He lives in such rivers as the trout does, and is usually taken with the same baits as the trout is, and after the same manner; for he will bite both at the minnow, or worm, or fly: though he bites not often at the minnow, and is very gamesome at the fly, and much simpler, and therefore bolder than a trout; for he will rise twenty times at a fly, if you miss him, and yet rise again. He has been taken with a 
fly made of the red feathers of a parakita, a strange outlandish bird; and he will rise at a fly not unlike a gnat or a small moth, or indeed at most flies that are not too big. $\mathrm{He}$ is a fish that lurks close all winter, but is very pleasant and jolly after mid-April, and in May, and in the hot months: he is of a very fine shape, his flesh is white; his teeth, those little ones that he has, are in his throat, yet he has so tender a mouth, that he is oftener lost after an angler has hooked him, than any other fish. Though there be many of these fishes in the delicate River Dove and Trent, and some other small rivers, as that which runs by Salisbury, yet he is not so general a fish as the trout, nor to me so good to eat or to angle for. And so I shall take my leave of him; and now come to some observations of the salmon, and how to catch him. 


\section{CHAPTER VII}

\section{OBSERVATIONS ON THE SALMON; WITH DIREGTIONS}

HOW TO FISH FOR HIM

\section{[fourtb Dav]}

Pisc. The Salmon is accounted the king of fresh water fish ; and is ever bred in rivers relating to the sea, yet so high or far from it, as admits of no tincture of salt or brackishness. He is said to breed or cast his spawn, in most rivers, in the month of August: some say, that then they dig a hole or grave in a safe place in the gravel, and there place their eggs or spawn, after the melter has done his natural office, and then hide it most cunningly, and cover it over with gravel and stones and then leave it to that Creator's protection, who, by a gentle heat which $\mathrm{He}$ infuses into that cold element, makes it brood and beget life in the spawn, and to become samlets early in the spring next following.*

The salmons having spent their appointed time, and done this natural duty in the fresh waters, they then haste to the sea before winter, both the melter and spawner: but if they be stopped by flood-gates or weirs or lost in the fresh waters, then those so left behind

* If salmon spawned in August, which not one in many thousand does, there would be young salmon (salmon-fry) in December, nay, in November. Salmon ova are incubated in about 120 days on the average-in the winter months in 140 days; in those of autumn and winter in about 100 days. The duration of the incubating time depends on the temperature of atmosphere and water. Salmon spawn deposited and impregnated on the 1st of August, would be hatched very probably by the 1 st of November, whereas spawn deposited in November would not be incubated before March. The temperature at the two periods would make the difference.-E. 
by degrees grow sick, and lean, and unseasonable, and kipper ; that is to say, have bony gristles grow out of their lower chaps, not unlike a hawk's beak, which hinders their feeding; and in time, such fish, so left behind, pine away and die. It is observed, that he may live thus, one year from the sea; but he then grows insipid and tasteless, and loses both his blood and strength, and pines and dies the second year. And it is noted, that those little salmons called skeggers, which abound in many rivers relating to the sea, are bred by such sick salmons that might not go to the sea; and that though they abound, yet they never thrive to any considerable bigness.

But if the old salmon gets to the sea, then that gristle, which shews him to be kipper, wears away, or is cast off, as the eagle is said to cast his bill ; and he recovers his strength, and comes next summer to the same river, if it be possible, to enjoy the former pleasures that there possessed him; for, as one has wittily observed, he has, like some persons of honour and riches, which have both their winter and summer houses, the fresh rivers for summer, and the salt water for winter, to spend his life in; which is not, as Sir Francis Bacon hath observed in his History of Life and Death, above ten years. And it is to be observed, that though the salmon does grow big in the sea, yet he grows not fat but in fresh rivers; and it is observed, that the farther they get from the sea, they be both the fatter and better.*

* Salmon, having spawned, proceed to sea immediately they have recovered from the exhaustion consequent on spawning. It is, therefore, in the spring, before summer, and not as Walton says, "before winter," that they generally migrate sea-ward. Their remaining for a year, under any circumstances, in fresh water, after they have become adult, never occurs. The gristle, or crook-shaped excrescence, is only found in male salmon, generally about spawning time, and some weeks afterwards, and disappears as the fish gets into condition, to re-appear again the following breeding season. The use of this excrescence is not accurately known. Skeggers are smolts, the one-year-old produce of healthy, and not of "sick salmons." 
Next I shall tell you, that though they make very hard slift to get out of the fresh rivers into the sea, yet they will make a harder shift to get out of the salt into the fresh rivers, to spawn, or possess the pleasures that they have formerly found in them : to which end, they will force themselves through flood-gates, or over weirs or hedges, or stops in the water, even to a height beyond common belief. Gesner speaks of such places as are known to be above eight feet high above water. And our Camden mentions, in his Britannia, the like wonder to be in Pembrokeshire, where the River Tivy falls into the sea; and that the fall is so downright, and so high, that the people stand and wonder at the strength and sleight by which they see the salmon use to get out of the sea into the said river; and the manner and height of the place is so notable, that it is known, far, by the name of the "Salmon-leap." Concerning which, take this also out of Michael Drayton,* my honest old friend; as he tells it you, in his Polyolbion:

And when the salmon seeks a fresher stream to find, Which hither from the sea comes yearly by his kind;

Salmon cannot be called sick, except between the periods of spawning and going to sea. They are then called "kelts," and not " kippers." A " kipper " now means a salmon cured by salt, sugar, and drying. It is in the sea, and not in fresh water, that salmon grow "big and fat." After the first year they do not increase in size in fresh water, but, on the contrary, diminish in bulk. When we say a " clear fresh-run" salmon, we mean one in good condition, bright and fat, and caught just on its return from the sea to its native river. In a few days afterwards, it is no longer clear and fresh-run, and in two or three weeks loses its fat or eurd, becomes comparatively lean, and almost black on the head, gill-covers and back. This is the result of its sojourn in fresh water, in which it no longer finds that food on which it thrived in its salt-water feeding-grounds. -E.

* An excellent poet, born in Warwickshire, 1563. Among his works, is the Polyolbion, a chorographical description of the rivers, mountains, forests, castles, ete., in this island. Though this poem has great merit, it is rendered much more valuable by the learned notes of Mr. Selden. The author died in 1631, and lies buried among the poets in Westminster Abbey.-H. 
As he tow'rds season grows, and stems the wat'ry tract Where Tivy falling down, makes a high cataract, Forced by the rising rocks that there her course oppose, As though within her bounds they meant her to inclose; Here, when the labouring fish does at the foot arrive, And finds that by his strength he does but vainly strive, His tail takes in his mouth,* and, bending like a bow That's to full compass drawn, aloft himself doth throw ; Then springing at his height, as doth a little wand

That, bended end to end, and started from man's hand, Far off itself doth cast; so does the salmon vault :

And if at first he fail, his second summersault He instantly essays; and from his nimble ring, Still yerking, never leaves until himself he fling Above the opposing stream-

This Michael Drayton tells you of this leap or summersault of the salmon.

And next I shall tell you, that it is observed by Gesner and others, that there is no better salmon than in England; and that though some of our northern counties have as fat and as large as the River Thames, yet none are of so excellent a taste.

And as I have told you that Sir Francis Bacon observes, the age of a salmon exceeds not ten years; so let me next tell you, that his growth is very sudden : it is said, that after he is got into the sea, he becomes from a samlet, not so big as a gudgeon, to be a salmon, in as short a time as a gosling becomes to be a goose. Much of this has been observed by tying a ribbon, or some known tape or thread, in the tail of some young salmons, which have been taken in weirs as they have swimmed

* The salmon never curves itself, or puts its tail in its mouth for the purpose of jumping from the water. It is by means of its fins that it throws itself from the water. It cannot jump perpendicularly to the height of eight feet, but may, probably, if there be s ifficient depth of water, jump six feet. In shallow water not half that distance. Its spring to surmount cascades or weirs is not perpendicular-not an upright standing leap-but, as it were, a running jump forwards, gradually attaining, in extreme instances, a height of six feet.-E. 
towards the salt water, and then by taking a part of them again with the known mark at the same place at their return from the sea, which is usually about six months after ; $*$ and the like experiment hath been tried upon young swallows, who have, after six months' absence, been observed to return to the same chimney, there to make their nests and habitations for the summer following: which has inclined many to think, that every salmon usually $t$ returns to the same river in which it was bred, as young pigeons taken out of the same dove-cote have also been observed to do.

And you are yet to observe farther, that the he-salmon is usually bigger than the spawner; and that he is more kipper, and less able to endure a winter in the fresh water than she is : yet she is, at that time of looking less kipper and better, as watery, and as bad meat. $\neq$

And yet you are to observe, that as there is no general rule without an exception, so there are some few rivers in this nation, that have trouts and salmons in season in winter, as it is certain there be in the River Wye in Monmouthshire, where they be in season, as Camden observes, from September till April.§ But,

- On an average, salmon return from sea to their native rivers in three months, rarely in a month, but very frequently in two. A sea-sojourn of four months is rare ; one of six quite abnormal.-E.

† Not only " usually," but always, if not disabled or killed.-E.

‡ This short paragraph is erroneous. A female salmon may be twice as large, or twice as small, as the malo with which she consorts on the spawning bed. She is frequently obliged to mate with male fish of all sizes and ages, nay, with small male trout. If a male and female salmon, the produce of the same brood, were to consort, after having been the same time on the same feedingground at sea, the female would be the larger fish. She suffers more from the effects of spawning than the male, and he is better, not "less, able to endure a winter in the fresh water than she is." He more promptly recovers from the "kelt" state, and is sooner fitted for his sea voyage.-E.

\$ I do not think there are any rivers in the empire which have the common, non-migratory trout " in season in winter." But there are a few rivers, the majority of which are Welsh, in which salmon are in season, or at least clean and fresh-run in winter-in November and December. These Iish are late spawners. Very early spawners 
my scholar, the observation of this and many other things, I must in manners omit, because they will prove too large for our narrow compass of time, and therefore I shall next fall upon my directions how to fish for this salmon.

And for that, first you shall observe, that usually he stays not long in a place, as trouts will, but, as I said, covets still to go nearer the spring-head; and that he does not, as the trout and many other fish, lie near the water-side, or bank, or roots of trees, but swims in the deep and broad parts of the water,* and usually in the middle, and near the ground, and that there you are to fish for him, and that he is to be caught as the trout

may be taken, in very small numbers in January, in what are considered the " early " salmon rivers of Ireland and Scotland.-E.

* The salmon, in coming up the estuaries, seldom swims in the middle, but by the sides, and for that reason he is caught in the stakenets that project, some hundred yards, or more, into the tidal waters. In rivers his haunts are various; sometimes close by the banks, in an eddy or little current, formed by rocks or roots; sometimes a little further out ; sometimes in the middle, or at the sides, of the rapidly running tails of pools; sometimes at their head; sometimes in the middle of deep or shallow currents. In fine, in any spot to which the current or the chicf strength of it, tends or diverges, thereby bringing some sort of food to the salmon on the look out for it. Two rocks, a yard or two apart, will form an angular current, or a wedge-like one. At the point of the wedge, no matter whether in the middle of the river, or by its sides, salmon surely lie, because to that point insects, larvæ, worms, and other food are washed, sucked in at the head of the triangular rapid formed by the two rocks. If a sharp-run is caused by a rock placed at a short distance from the bank, the salmon will lie close by the inside of the rock, or near the bank, or at the tail of the sharp-run. The precise lairs of salmon in different rivers can only be known by experience. No general rule respecting them will hold good. On first fishing a river, you must have a guide-a fisherman, born, as it were, on its banksand he will show you what are called the best "salmon-casts." Without such a guide, you will waste much time, by fishing likelylooking spots, but which, from some cause or other unknown to you, are not frequented by salmon ; and you will pass over, without fishing them, unfavourable spots apparently, but where salmon lie, from some cause also unknown to you. In the pools immediately above waterfalls, or any difficult " salmon-leap," salmon very rarely take the fly, or any other bait. They stop in tliese pools for the sake of repose, and are disinclined to disturb it even for the sake of food. To the non-local salmon-fisher a local guide is indispensable.-E. 
is, with a worm, a minnow, which some call a penk, or with a fly.

And you are to observe, that he is very seldom observed to bite at a minnow, yet sometimes he will, and not usually at a fly; but more usually at a worm, and then most usually at a lob or garden-worm, which should be well scoured, that is to say, kept seven or eight days in moss before you fish with them: and if you double your time of eight into sixteen, twenty, or more days, it is still the better; for the worms will still be clearer, tougher, and more lively, and continue so longer upon your hook; and they may be kept longer by keeping them cool and in fresh moss, and some advise to put camphor into it.

Note also, that many used to fish for a salmon with a ring of wire on the top of their rod, through which the line may run to as great a length as is needful when he is hooked. And to that end, some use a wheel about the middle of their rod, or near their hand; which is to be observed better by seeing one of them, than by a large demonstration of words.

And now I shall tell you that which may be called a secret: I have been a-fishing with old Oliver Henley, now with God, a noted fisher both for trout and salmon, and have observed, that he would usually take three or four worms out of his bag, and put them into a little box in his pocket, where he would usually let them continue half an hour or more, before he would bait his hook with them. I have asked him his reason, and he has replied : "He did but pick the best out to be in readiness against he baited his hook the next time:" but he has been observed, both by others and myself, to catch more fish than I or any other body that has ever gone a-fishing with him could do, and especially salmons; and I have been told lately by one of his most intimate and secret friends, that the box in which he put those worms, was 
anointed with a drop, or two or three, of the oil of ivyberries, made by expression or infusion; and told, that by the worms remaining in that box an hour, or a like time, they had incorporated a kind of smell that was irresistibly attractive, enough to force any fish within the smell of them, to bite. This I heard not long since from a friend, but have not tried it ; yet I grant it probable, and refer my reader to Sir Francis Bacon's Natural History, where he proves fishes may hear, and doubtless can more probably smell : and I am certain Gesner says the otter

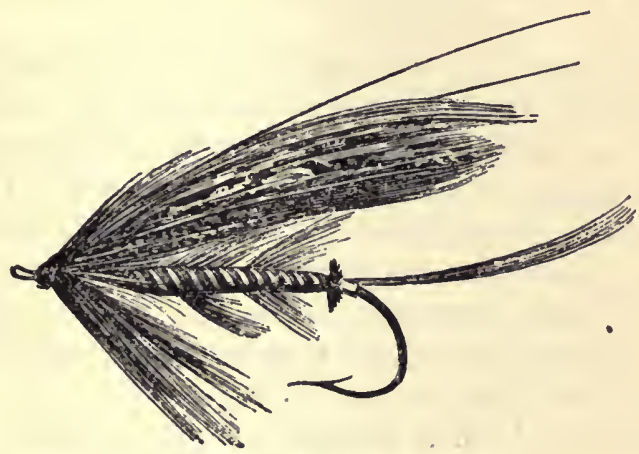

THE SALMON-FLY

can smell in the water, and I know not but that fish may do so too: it is left for a lover of angling, or any that desires to improve that art, to try this conclusion.*

I shall also impart two other experiments (but not tried by myself), which I will deliver in the same words that they were given me, by an excellent angler, and a very friend, in writing : he told me the latter was too good to be told, but in a learned language, lest it should be made common.

"Take the stinking oil drawn out of the polypody of the oak by a retort, mixed with turpentine and hive-honey,

" By the word " conclusion," Walton means " experiment." He was too practical a bottom-fisher to have faith in scented baits.-E. 
and anoint your bait therewith, and it will doubtless draw the fish to it."

The other is this: "Vulnera hederæ grandissimæ inflicta sudant balsamum oleo gelato, albicantique persimile, odoris vero longè suavissimi."

It is supremely sweet to any fish, and yet assafœtida may do the like.

But in these things I have no great faith, yet grant it probable, and have had from some chemical men, namely, from Sir George Hastings and others, an affirmation of them to be very advantageous : but no more of these, especially not in this place.

I might here, before I take my leave of the salmon, tell you, that there is more than one sort of them; as, namely, a tecon, and another called in some places a samlet, or by some a skegger: but these and others, which I forbear to name, may be fish of another kind, and differ as we know a herring and a pilchard do, which, I think, are as different as the rivers in which they breed, and must by me be left to the disquisitions of men of more leisure, and of greater abilities, than I profess myself to have.*

And lastly, I am to borrow so much of your promised patience as to tell you, that the trout or salmon, being in season, have, at their first taking out of the water,

* There is a fish, in many rivers, of the salmon kind, which, though very small, is thought by some curious persons to be of the same species ; and this, I take it, is the fish known by the different names of salmon-pink, shedders, skeggers, and last-springs. But there is another small fish very much resembling these in shape and colour, called the gravel-last-spring, found only in the River Wye and Severn; which is, undoubtcdly, a distinct species. These spawn about the beginning of September: and in the Wye I have taken them with an ant-fly as fast as I could throw. Perhaps this is what Walton calls the tecon.-H.

[NoTE.-All the flsh named, except the gravel-last-spring, are salmon-fry of different ages, from three or four mouths to twelve. The gravel-last-spring is, in all probability, the little trout, called a " parr." It is found in many rivers besides the Wye and Severn. Walton's "tecon" may be the parr. Samlet, skegger, etc., are local names for young salmon, before their first migration to sea. -E.] 
which continues during life, their bodies adorned, the one with such red spots, and the other with such black or blackish spots, as give them such an addition of natural beauty, as I think, was never given to any woman by the artificial paint or patches in which they so much pride themselves in this age. And so I shall leave them both, and proceed to some observations on the pike. 


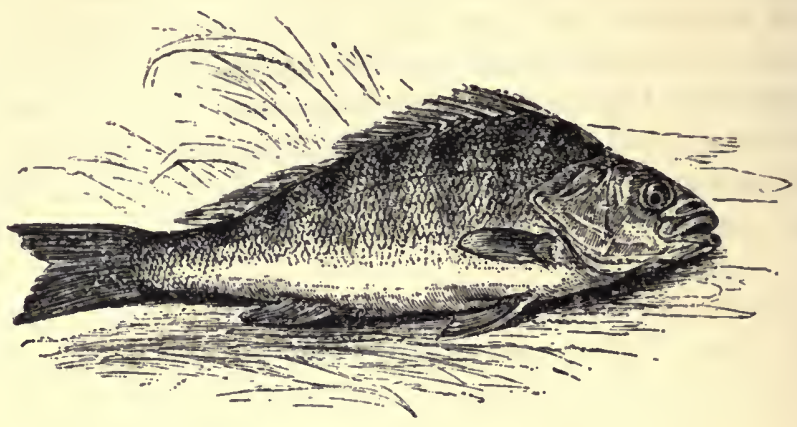

\section{PERCH}

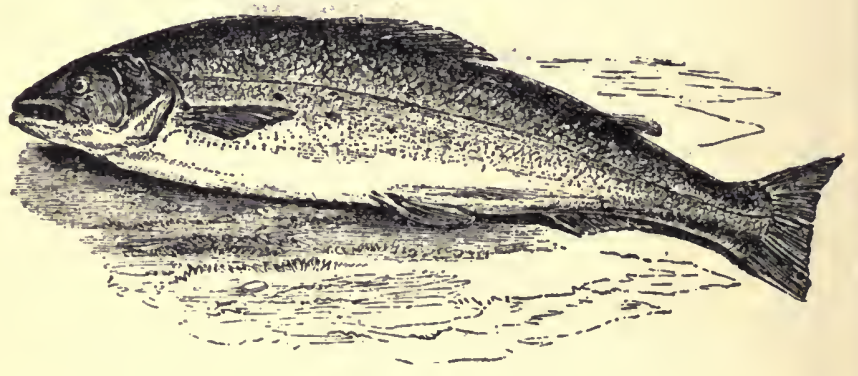

SALMON

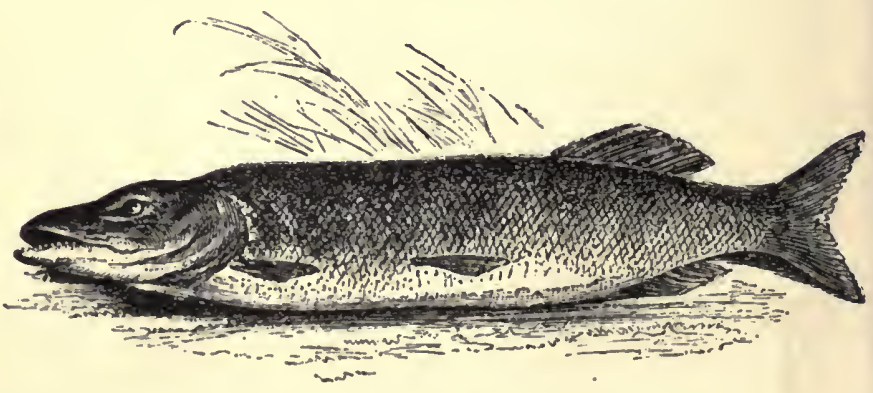




\section{CHAPTER VIII}

\section{OBSERVATIONS ON THE LUCE OR PIKE; WITH}

DIRECTIONS HOW TO FISH FOR HIM

\section{[Jfourtb Dav]}

Pisc. The mighty Luce or Pike is taken to be the tyrant, as the salmon is the king, of the fresh waters. It is not to be doubted, but that they are bred, some by generation, and some not,* as namely, of a weed called pickerel weed, unless learned Gesner be much mistaken, for he says, this weed and other glutinous matter, with the help of the sun's heat, in some particular months, and some ponds apted for it by nature, do become pikes. But, doubtless,

* The simplicity of Walton is here manifest. To fancy " pickerelweed " or any other plant producing fish by means of the sun's heat is exceedingly ridiculous, but not more so than the modern belief of many persons that horse-hair thrown into ponds will become eels. Reader, all river fish have productive spawn. All female fish have ova or eggs, commonly called the " hard roe" ; all male river fish have milts usually named the soft roe. Unless the former be impregnated by the latter, there will be no reproduction. The salmon tribe deposit their spawn beneath gravel beds; the carp tribes on and amongst the subaqueous portions of aquatic plants to which the spawn adheres by its inherent viscous properties. Mr. Blaine (Encyclopedia of Rural Sports, p. 1102), accurately states :- " Jack and pike spawn either in March or April, according to the forwardness of the spring or temperature of the atmosphere, as well as the situation of the water. They retire for the reproductive purpose in pairs, quitting the rivers for the creeks and ditches. When confined in still waters they seek the stillest parts of them, and frequently occupy a mud-bed, or remain towards the edges or shallows, depositing their spawn among aquatic plants, of which the reed and rush varieties are favourites. The male may be seen during this time accompanying the femalc with much attention, and when the fecundating milt has been deposited over the ova, the pair retire into deep water, and seem to fecl no further solicitude for the result of the process."-E. 
divers pikes are bred after this manner, or are brought into some ponds some such other ways as is past man's finding out, of which we have daily testimonies.

Sir Francis Bacon, in his History of Life and Death, observes the pike to be the longest lived of any fresh water fish; and yet he computes it to be not usually above forty years; and others think it to be not above ten years ; and yet Gesner mentions a pike taken in Swedeland, in the year 1449 , with a ring about his neck, declaring he was put into that pond by Frederick the Second, more than two hundred years before he was last taken, as by the in scription in that ring, being Greek, was interpreted by the then Bishop of Worms.* But of this no more ; but that it is observed, that the old or very great pikes have in them more of state than goodness; the smaller or middle-sized pikes being, by the most and choicest palates, observed to be the best meat: and, contrary, the eel is observed to be the better for age and bigness.

All pikes that live long prove chargeable to their keepers, because their life is maintained by the death of so many other fish, even those of their own kind; which has made him by some writers to be called the tyrant of the rivers, or the fresh-water wolf, by reason of his bold, greedy, devouring disposition; which is so keen, as Gesner relates a man going to a pond, where it seems a pike had devoured all the fish, to water his mule, had a pike bit his mule by the lips; to which the pike hung so fast, that

* The story is told (more correctly) by Hakewill, who, in his Apologie of the Power and Providence of God, fol. Oxf. 1635, part i. p. 145 , says, - " I will close up this chapter with a relation of Gesner's, in his epistle to the Emperor Ferdinand, prefixed before his booke De Piscibus, touching the long life of a pike which was cast into a pond or poole near Hailebrune in Suabia, with this inscription ingraven upon a collar of brass fastened about his nccke. 'Ego sum ille piscis huic stagno omnium primus impositus per mundi rectoris Frederici Secundi manus, 5 Octobris, anno 1230.' I am that fish which was first of all cast into this poole by the hand of Fredericke the Second, governour of the world, the fifth of October, in the year 1230.- He was again taken up In the year 1497 ; and by the inscription, it appeared he had then lived there 267 veares." $-\mathrm{H}$. 
the mule drew him out of the water, and by that accident the owner of the mule angled out the pike. And the same Gesner observes, that a maid in Poland had a pike bit her by the foot, as she was washing clothes in a pond. And I have heard the like of a woman in Killingworth pond, not far from Coventry. But I have been assured by my friend Mr. Seagrave, of whom I spake to you formerly, that keeps tame otters, that he hath known a pike in extreme hunger fight with one of his otters for a carp that the otter had caught, and was then bringing out of the water. I have told you who relate these things, and tell you they are persons of credit; and shall conclude this observation, by telling you what a wise man has observed, "It is a hard thing to persuade the belly, because it has no ears." *

* Bowlker, in his Art of Angling, gives the following instance of the exceeding voracity of this fish : "My father catched a pike in Barn-Meer (a large standing water in Cheshire), was an cll long, and weighed thirty-five pounds, which he brought to the Lord Kholmondely: his lordship ordcred it to be turned into a canal in the garden, wherein were abundance of several sorts of fish. About twelve months after, his lordship draw'd the canal, and found that this overgrown pike had devoured all the fish, except one large carp, that weighed between nine and ten pounds, and that was bitten in several places. The pike was then put into the canal again, together with abundance of fish with him to feed upon, all which he devoured in less than a year's time; and was observed by the gardencr and workmen there, to take the ducks and other waterfowl under water: whereupon they shot magpies and crows, and threw them into the canal, which the pike took beforc their eyes: of this they acquainted their lord, who thereupon ordered the slaughtermen to fling in calves' bellies, chickens' guts, and such like garbage to him, to prey upon; but being soon after neglected, he died as supposed for want of food." The following relation was inserted as an article of news in one of the London papers, 2nd Jan. 1765. Extract of a letter from Littleport, Dec. 17.- " About ten days ago a large pike was caught in the River Ouse, which weighed upwards of twenty-eight pounds, and was sold to a gentleman in the neighbourhood for a guinea. As the cook-maid was gutting the fish, she found to her great astonishment, a watch with a black ribbon, and two steel seals annexed, in the body of the pike; the gentleman's butler, upon opening the watch, found the maker's name, Tlionias Cranefield, Burnham, Norfolk. Upon a strict enquiry, it appears that the said watch was sold to a gentleman's servant, who was unfortunately drowned about six wceks ago, in his way to Cambridge, between this place and South Ferry. The 
But if these relations be disbelieved, it is too evident to be doubted, that a pike will devour a fish of his own kind that shall be bigger than his belly or throat will receive, and swallow a part of him, and let the other part remain in his mouth till the swallowed part be digested, and then swallow that other part, that was in his mouth, and so put it over by degrees; which is not unlike the ox, and some other beasts, taking their meat, not out of their mouth immediately into their belly, but first into some place betwixt, and then chew it, or digest it by degrees after, which is called chewing the cud. And, doubtless, pikes will bite when they are not hungry; but, as some think, even for very anger, when a tempting bait comes near to them.

watch is still in the possession of Mr. John Roberts, at the Cross Keys, in Littleport, for the inspection of the public." And this is in the same paper, the 25th of the same month and year. "On Tuesday last, at Lillishall lime-works, near Newport, a pool about nine yards deep, which has not yet been fished for ages, was let off by means of a level brought up to drain the works, when an cnormous pike was found; he was drawn out by a rope fastened round his head and gills, amidst hundreds of spectators, in which service a great many men were enıloyed: he weighed upwards of 170 pounds, and is thought to be the largest ever seen. Some time ago, the clerk of the parish was trolling in the above pool, when his bait was seized by this furious creature, which by a sudden jerk pulled him in, and doubtless would have devoured him also, had he not by wonderful agility and dexterous swimming, escaped the dreadful jaws of this voracious animal." In Dr. Plot's History of Staffordshire, 246, are sundry relations of pike of great magnitude, one in particular, caught in the Thame, an ell and two inches long. The following story, containing further cvidence of the voracity of this fish, with the addition of a pleasant circumstance, I met with in Fuller's Worthies, Lincolnshire, page 144. "A cub fox drinking out of the River Arnus in Italy, had his head seized on by a mighty pike, so that neither could free themselves, but were ingrappled together. In this contest a young man runs into the water, takes them out both alive, and carrieth them to the Duke of Florence, whose palace was hard by. The porter would not admit him without promising of sharing his full half in what the duke should give lim ; to which he (hopeless otherwise of entrance) condescended: the duke, highly affected with the rarity, was about giving him a good reward, which tlic other refused, desiring his highness would appoint one of his guard to give him a lundred lashes, that so, his porter might have fifty, according to his composition. And here my intelligence leaveth me how much farther the jest was followed." - I 
And it is observed, that the pike will eat venomous things, as some kind of frogs are, and yet live without being harmed by them; for, as some say, he has in him a natural balsam, or antidote against all poison. And he has a strange heat, that though it appears to us to be cold, can yet digest or put over any fish-flesh, by degrees, without being sick. And others observe that he never eats the venomous frog till he have first killed her, and then, as ducks are observed to do to frogs in spawning time, at which time some frogs are observed to be venomous,- - so thoroughly washed her, by tumbling her up and down in the water, that he may devour her without danger. And Gesner affirms that a Polonian gentleman did faithfully assure him, he had seen two young geese at one time in the belly of a pike. And doubtless a pike, in his height of hunger, will bite at and devour a dog that swims in a pond; and there have been examples of it, or the like : for, as I told you, "The belly has no ears when hunger comes upon it."

The pike is also observed to be a solitary, melancholy, and a bold fish: melancholy, because he always swims or rests himself alone, and never swims in shoals or with company, as roach and dace and most other fish do; and bold, because he fears not a shadow, or to see or be seen of anybody, as the trout and chub and all other fish do.

And it is observed by Gesner, that the jaw-bones and hearts and galls of pikes are very medicinable for several diseases ; or to stop blood, to abate fevers, to cure agues, to oppose or expel the infection of the plague, and to be many ways medicinable and useful for the good of mankind : but he observes, that the biting of a pike is venomous, and hard to be cured.

And it is observed, that the pike is a fish that breeds but once a year; and that other fish, as namely loaches, do breed oftener, as we are certain tame pigeons do almost 
every month; and yet the hawk, a bird of prey, as the pike is of fish, breeds but once in twelve months.* And you are to note, that his time of breeding, or spawning, is usually about the end of Fcbruary, or somewhat later, in March, as the weather proves colder or warmer ; and to note, that his manner of breeding is thus : a he and a shepike will usually go together out of a river into some ditch or creek, and that there the spawner casts her ejgs, and the melter hovers over her all that time that she is casting her spawn, but touches her not. $\uparrow$

* Walton here hints at a dispensation of Providence, by which animals of prey are rendered less productive of their species than others, particularly than those living things that furnish food for man. There are numerous exceptions. Animals, that come under the denomination of "vermin," are in many instances exceedingly prolific; far more so than the useful cow and sheep. The salmon, so valuable as an edible, does not spawn more frequently than the pike; nor does the pheasant breed oftener than the hawk, though it does more productively. Animals of prey abound in the uninluabited forest and desert, and if some are very rare, and others extinct, in populous countries, we must impute the fact to the destructive devices of man, rather than to limited natural powers of productiveness. - E.

$\dagger$ Very late discoveries of naturalists contradict this hypothesis concerning the generation of fishes, and prove that they are produced by the conjunction of the male and female, as other animals are. See the Philosophical Transactions, vol. XlviII. part II., for the year 1754 , p. 870.- $\mathrm{H}$.

[Discoveries later still, in the shape of repeated experiments, have proved that Walton was more correct than the Philosophic Transactions for the year 1754. The hypothesis that fish-we specifically refer to river fish-" are produced by the conjunction of the male and female, as other animals are," is rejected by all eminent modern naturalists. No sexual conjunction takes place. The female fish deposits her spawn or ova, which the male fish fecundates by emitting upon it his spawn or milt. The reader will remark, that Walton has already said, at the beginning of this chapter, of pike, "' 'Tis not to be doubted but that they are bred, some by generation, and some not." In the present passage :- "A he and she-pike will usually go together out of a river into some ditch or creek, and there the spawner casts lier eggs, and the milter hovers over her all that time she is casting her spawn, but touches her not "-he sets himself right, and gives the real process of pike re-production. One of Walton's greatest crrors is, that he places such confidence in what were in his day called learned writers, particularly German ones. They were as bad naturalists in his time as they are now, and for the excellent reason that they indulge in day-dreams about the 
I might say more of this, but it might be thought curiosity or worse, and shall therefore forbear it; and talse up so much of your attention as to tell you, that the best of pikes are noted to be in rivers; next, those in great ponds or meres; and the worst, in small ponds.

But before I proceed farther, I am to tell you, that there is a great antipathy betwixt the pike and some frogs : and this may appear to the reader of Dubravius, a bishop in Bohemia, who, in his book Of Fish and Fish-ponds,* relates what he says he saw with his own eyes, and could not forbear to tell the reader; which was:

"As he and the Bishop Thurzo were walking by a large pond in Bohemia, they saw a frog, when the pike lay very sleepily and quiet by the shore side, leap upon his head; and the frog having expressed malice or anger by his swollen cheeks and staring eyes, did stretch out his legs and embraced the pike's head, and presently reached them to his eyes, tearing with them and his teeth, those tender parts : the pike moved with anguish, moves up and down the water, and rubs himself against weeds and whatever he thought might quit him of his enemy; but all in vain, for the frog did continue to ride triumphantly, and to bite and torment the pike, till his strength failed, and then the frog sunk with the pike to the bottom of the water; then presently the frog appeared again at the top and croaked, and seemed to rejoice like a conqueror; after which he presently retired to his secret hole. The bishop, that had beheld the battle, called his fishermen to fetch his nets, and by all means to get the pike, that they might declare what had happened: and the pike was drawn forth, and both his eyes eaten out; at which when they began to wonder, the fisherman wished them to forbear,

abnormal habits and singular instincts of animalia, instead of trying to account for them by facts derived from actual observation. -E.] Inn. 
and assured them he was certain that pikes were often so served."

I told this, which is to be read in the sixth chapter of the first book of Dubravius, unto a friend, who replied, " It was as improbable as to have the mouse scratch out the cat's eyes." But he did not consider, that there be fishing frogs, which the Dalmatians call the water-devil, of which I might tell you as wonderful a story; but I shall tell you, that 'tis not to be doubted, but that there be some frogs so fearful of the water-snake, that, when they swim in a place in which they fear to meet with him, they then get a reed across into their mouths, which, if they two meet by accident, secures the frog from the strength and malice of the snake; and note, that the frog usually swims the fastest of the two.

And let me tell you, that as there be water and landfrogs, so there be land and water-snakes. Concerning which, take this observation, that the land-snake breeds and hatches her eggs, which become young snakes, in some old dunghill, or a like hot place; but the water-snake, which is not venomous, and, as I have been assured by a great observer of such secrets, does not hatch, but breed her young alive, which she does not then forsake; but bides with them, and in case of danger will take them all into her mouth and swim away from any apprehended danger, and then let them out again when she thinks all danger to be passed; these be accidents that we anglers sometimes see, and often talk of.

But whither am I going ? I had almost lost myself, by remembering the discourse of Dubravius. I will therefore stop here, and tell you, according to my promise, how to catch the pike.

His feeding is usually of fish or frogs, and sometimes a weed of his own called pickerel-weed, of which I told you some think pikes are bred; for they have observed, that where none have been put into ponds, yet the $\mathrm{j}$ have there 
found many, and that there has been plenty of that weed in those ponds, and [they think] that that weed both breeds and feeds them: but whether those pikes so bred will ever breed by generation as the others do, I shall leave to the disquisitions of men of more curiosity and leisure than I profess myself to have : and shall proceed to tell you, that you may fish for a pike, either with a ledger or a walking-bait; and you are to note, that I call that a ledger-bait, which is fixed or made to rest in one certain place when you shall be absent from it; and I call that a walking-bait which you take with you, and have ever in motion. Concerning which two, I shall give you this direction, that your ledger-bait is best to be a living bait (though a dead one may catch), whether it be a fish or a frog: and that you may make them live the longer, you may, or indeed you must, take this course :

First, for your live-bait. Of fish, a roach or dace is, I think, best and most tempting (and a perch is the longest lived on a hook) and having cut off his fin on his back, which may be done without hurting him, you must take your knife, which cannot be too sharp, and between the head and the fin on the back, cut or make an incision, or such a scar, as you may put the arming-wire of your hook into it, with as little bruising or hurting the fish as art and diligence will enable you to do ; and so carrying your arming-wire along his back, unto or near the tail of your fish, between the skin and the body of it, draw out that wire or arming of your hook at another scar near to his tail : then tie him about it with thread, but no harder than of necessity to prevent hurting the fish ; and the better to avoid hurting the fish, some have a kind of probe to open the way, for the more easy entrance and passage of your wire or arming : but as for these, time and a little experience will teach you better than I can by words; therefore I will for the present say no more of this, but 
come next to give you some directions how to bait your hook with a frog.

VEN. But, good master, did you not say even now, that some frogs are venomous, and is it not dangerous to touch them?

Pisc. Yes; but I will give you some rules or cautions concerning them. And first, you are to note, that there are two kinds of frogs; that is to say, if I may so express myself, a flesh and a fish-frog : by flesh-frogs, I mean frogs that breed and live on the land; and of these there be several sorts also, and of several colours, some being speckled, some greenish, some blackish or brown: the green frog, which is a small one, is by Topsell taken to be venomous, and so is the padock or frog padock, which usually keeps or breeds on the land, and is very large, and bony and big, especially the she-frog of that kind; yet these will sometimes come into the water, but it is not often; and the land-frogs are some of them observed by him to breed by laying eggs, and others to breed of the slime and dust of the earth, and that in winter they turn to slime again, and that the next summer that very slime returns to be a living creature; this is the opinion of Pliny, and Cardanus * (in his tenth book De Subtilitate) undertakes to give a reason for the raining of frogs : but if it were in my power, it should rain none but water-frogs, for those I think are not venomous, especially the right water-frog, which about February or March breeds in ditches by slime, and blackish eggs in that slime, about which time of breeding the he and she-frogs are observed to use divers summersaults, and to croak and make a noise, which the land-frog, or padock-frog, never does. Now of these water-frogs, if you intend to fish with a frog

* Hicronymus Cardanus, an Italian physician, naturalist, and astrologer, well-known by the many works he has published: he died at Rome 1576. It is said that he had foretold the day of his death, and that, when it approached, he suffered himself to die of hunger to preserve his reputation.-H. 
for a pike, you are to chuse the yellowist that you can get, for that the pike ever likes best. And thus use your frog, that he may continue long alive :

Put your hook into his mouth, which you may easily do from the middle of April till August; and then the frog's mouth grows up, and he continues so for at least six months without eating, but is sustained none but $\mathrm{He}$ whose name is Wonderful knows how: I say, put your hook, I mean the arming-wire, through his mouth, and out at his gills; and then with a fine needle and silk sew the upper part of his leg, with only one stitch, to the arming-wire of your hook; or tie the frog's leg, above the upper joint, to the arming-wire; and, in so doing, use him as though you loved him,* that is, harm him as little as you may possibly, that he may live the longer.

And now, having given you this direction for the baiting your ledger-hook with a live fish or frog, my next must be to tell you how your hook thus baited must or may be used, and it is thus: Having fastened your hook to a line, which, if it be not fourteen yards long, should not be less than twelve, you are to fasten that line to any bough near to a hole where a pike is, or is likely to lie, or to have a haunt, and then wind your line on any forked stick, all your line, except half a yard of it, or rather more, and split that forked stick with such a nick or notch at one end of it as may keep the line from any more of it ravelling from about the stick than so much of it as you intend; and choose your forked stick to be of that bigness as may keep the fish or frog from pulling the forked stick under the water till the pike bites; and then the pike having pulled the line forth of the cleft or nick of that

* It is this expression, with the instructions given in the paragraph, on which is mainly founded the charge of cruelty against Walton, and no doubt gave rise to the lines of Byron so frequently quoted :-

"That quaint, old, crucl coxcomb, in his gullet

Should have a hook, and a small trout to pull it."

Don Juan, canto xiii. 
stick in which it was gently fastened, he will have line enough to go to his hold and pouch the bait; and if you would have this ledger-bait to keep at a fixed place, undisturbed by wind or other accidents, which may drive it to the shore-side, (for you are to note, that it is likeliest to catch a pike in the midst of the water,) then hang a small plummet of lead, a stone, or piece of tile, or a turf in a string, and cast it into the water with the forked stick, to hang upon the ground, to be a kind of anchor to keep the forked stick from moving out of your intended place till the pike come. This I take to be a very good way, to use so many ledger-baits as you intend to make trial of.

Or if you bait your hooks thus with live fish or frogs, and in a windy day, fasten them thus to a bough or bundle of straw, and by the help of that wind can get them to move across a pond or mere, you are like to stand still on the shore and see sport presently if there be any store of pikes; or these live baits may make sport, being tied about the body or wings of a goose or duck, and she chased over a pond: and the like may be done with turning three or four live baits thus fastened to bladders, or boughs, or bottles of hay or flags, to swim down a river, whilst you walk quietly alone on the shore, and are still in expectation of sport. The rest must be taught you by practice, for time will not allow me to say more of this kind of fishing with live baits.

And for your dead bait for a pike, for that you may be taught by one day's going a fishing with me, or any other body that fishes for him, for the baiting your hook with a dead gudgeon or a roach, and moving it up and down the water, is too easy a thing to take up any time to direct you to do it : and yet, because I cut you short in that, I will commute for it by telling you that that was told me for a secret : it is this :

Dissolve gum of ivy in oil of spike, and therewith anoint 
your dead bait for a pike, and then cast it into a likely place, and when it has lain a short time at the bottom, draw it towards the top of the water, and so up the stream, and it is more than likely that you have a pike follow with more than common eagerness.

And some affirm, that any bait anointed with the marrow of the thigh-bone of an hern,* is a great temptation to any fish.

These have not been tried by me, but told me by a friend of note, that pretended to do me a courtesy; but if this direction to catch a pike thus do you no good, yet I am certain this direction how to roast him when he is caught, is choicely good, for I have tried it, and it is somewhat the better for not being common; but with my direction you must take this caution, that your pike must not be a small one, that is, it must be more than half a yard, and should be bigger.

First, open your pike at the gills, and if need be, cut also a little slit towards the belly; out of these take his guts and keep his liver, which you are to shred very small with thyme, sweet-marjoram, and a little wintersavory: to these put some pickled oysters, and some anchovies, two or three, both these last whole; for the anchovies will melt, and the oysters should not: to these you must add also a pound of sweet butter, which you are to mix with the herbs that are shred, and let them all be well salted: if the pike be more than a yard long, then you may put into these herbs more than a pound, or if lie be less, then less butter will suffice : these being thus mixed with a blade or two of mace, must be puf into the

* No doubt Walton means the well-known bird, the heron, a great destroyer of fish, and lence, apparently, the notion that its marrow had some odoriferous attraction. Anointing any fish dead-bait for pike or for perch, or any other fish, is more superfluous, if possible, than gilding the purest Australian gold nugget. -E. 
pike's belly, and then his belly so sewed up, as to keep all the butter in his belly, if it be possible: if not, then as much of it as you possibly can ; but take not off the scales: then you are to thrust the spit through his mouth out at his tail ; and then take four, or five, or six split sticks or very thin laths, and a convenient quantity of tape or filleting: these laths are to be tied round about the pike's body from his head to his tail, and the tape tied somewhat thick to prevent his breaking or falling off from the spit : let him be roasted very leisurely, and often basted with claret wine and anchovies and butter mixed together, and also with what moisture falls from him into the pan: when you have roasted him sufficiently, you are to hold under him, when you unwind or cut the tape that ties him, such a dish as you purpose to eat him out of ; and let him fall into it with the sauce that is roasted in his belly; and by this means the pike will be kept unbroken and complete: then, to the sauce which was within, and also that sauce in the pan, you are to add a fit quantity of the best butter, and to squeeze the juice of three or four oranges : lastly, you may either put into the pike with the oysters two cloves of garlick, and take it whole out, when the pike is cut off the spit; or to give the sauce a haut-gout let the dish into which you let the pike fall, be rubbed with it : the using or not using of this garlick is left to your discretion.-M. B.

This dish of meat is too good for any but anglers, or very honest men; and I trust you will prove both, and therefore I have trusted you with this secret.

Let me next tell you, that Gesner tells us there are no pikes in Spain; and that the largest are in the Lake Thrasymene in Italy; and the next, if not equal to them, are the pikes of England; and that in England, Lincolnshire boasteth to have the biggest. Just so doth Sussex boast of four sorts of fish; namely, an Arundel Mullet, a 
Chichester Lobster, a Shelsey Cockle, and an Amerley Trout.

But I will take up no more of your time with this relation; but proceed to give you some observations of the carp, and how to angle for him, and to dress him, but not till he is caught. 


\section{CHAPTER IX}

OBSERVATIONS ON THE CARP; WITH DIRECTIONS

HOW TO FISH FOR HIM

\section{[jourtb \$ay]}

PISc. The Carp is the queen of rivers; a stately, a good, and a very subtle fish; that was not at first bred, nor hath been long in England, but is now naturalised. It is said, they were brought hither by one Mr. Mascal, a gentleman that then lived at Plumsted in Sussex, a county that abounds more with fish than any in this nation.

You may remember that I told you Gesner says there are no pikes in Spain; and doubtless there was a time, about a hundred or a few more years ago, when there were no carps in England, as may seem to be affirmed by Sir Richard Baker, in whose Chronicle you may find these verses :

Hops and turkeys, carps and beer, Came into England all in a year.

And doubtless as of sea-fish the herring dies soonest out of the water, and of fresh-water fish, the trout, so, except the eel, the carp endures most hardness, and lives longest out of his own proper element. And, therefore, the report of the carp's being brought out of a foreign country into this nation is the more probable.

Carps and loaches are observed to breed several months in one year, which pikes and most other fish do not. And this is partly proved by tame and wild rabbits; 
and also by some ducks, which will lay eggs nine of the twelve months; and yet there be other ducks that lay not longer than about one month. And it is the rather to be believed, because you shall scarce or never take a male carp without a melt, and a female without a roe or spawn, and for the most part very much, and especially all the summer season. "And it is observed that they breed more naturally in ponds than in running waters, if they breed there at all; and that those that live in rivers are taken by men of the best palates to be much the better meat.

And it is observed, that in some ponds carps will not breed, especially in cold ponds; but where they will breed they breed innumerably: Aristotle and Pliny say six times in a year, if there be no pikes or perch to devour their spawn, when it is cast upon grass, or flags, or weeds, where it lies ten or twelve days before it be enlivened.

The carp, if he have water room and good feed, will grow to a very great bigness and length ; I have heard, to be much above a yard long.* It is said by Jovius, who hath writ of fishes, that in the Lake Lurian in Italy, carps have thriven to be more than fifty pounds weight: which is the more probable, for as the bear is conceived and born suddenly, and being born is but short-lived, so, on the contrary, the elephant is said to be two years in his dam's belly, some think he is ten years in it, and being born, grows in bigness twenty years; and it is observed too that he lives to the age of a hundred years. And it is also observed, that the crocodile is very longlived, and more than that, that all that long life he thrives in bigness; and so I think some carps do, especialiy in some places; though I never saw one above twentythree inches, which was a great and a goodly fish; but

* The widow of the late Mr. David Garrick, of Drury Lane Theatre, once told me, that in her native country, Germany, sho had seen the head of a carp served up at table, big cnough to fll a large dish. $-\mathrm{H}$. 
have been assured there are of a greater size, and in England too.

Now, as the increase of carps is wonderful for their number, so there is not a reason found out, I think, by any, why they should breed in some ponds, and not in others of the same nature for soil and all other circumstances. And as their breeding, so are their decays also very mysterious: I have both read it, and been told by a gentleman of tried honesty, that he has known sixty or more large carps put into several ponds near to a house, where, by reason of the stakes in the ponds, and the owner's constant being near to them, it was impossible they should be stole away from him; and that when he has, after three or four years, emptied the pond, and expected an increase from them by breeding young ones (for that they might do so, he had, as the rule is, put in three melters for one spawner), he has, I say, after three or four years, found neither a young nor old carp remaining. And the like I have known of one that had almost watched the pond, and at a like distance of time, at the fishing of the pond, found, of seventy or eighty large carps, not above five or six ; and that he had forborne longer to fish the said pond, but that he saw, in a hot day in summer, a large carp swim near the top of the water with a frog upon his head; and that he, upon that occasion, caused his pond to be let dry : and I say, of seventy or eighty carps, only found five or six in the said pond, and those very sick and lean, and with every one a frog sticking so fast on the head of the said carps, that the frog would not be got off without extreme force or killing. And the gentleman that did affirm this to me, told me he saw it; and did declare his belief to be, and I also believe the same, that he thought the other carps, that were so strangely lost, were so killed by the frogs, and then devoured.

And a person of honour, now living in Worcestershire, 
assured me he had seen a necklace or collar of tadpoles, hang like a "chain or necklace of beads about a pike's neck, and to kill him; whether it were for meat or malice, must be to me a question.

But I am fallen into this discourse by accident, of which I might say more, but it has proved longer than I intended, and possibly may not to you be considerable : I shall therefore give you three or four more short observations of the carp, and then fall upon some directions how you shall fish for him.

The age of carps is by Sir Francis Bacon, in his History of Life and Death, observed to be but ten years; yet others think they live longer. Gesner says, a carp has been known to live in the Palatinate above a hundred years : * but most conclude that, contrary to the pike or luce, all carps are the better for age and bigness. The tongues of carps are noted to be choice and costly meat, especially to them that buy them: but Gesner says, carps have no tongue like other fish, but a piece of flesh-like fish in their mouth like to a tongue, and should be called a palate: but it is certain it is choicely good: and that the carp is to be reckoned amongst those leathermouthed fish, which I told you have their teeth in their throat, and for that reason he is very seldom lost by breaking his hold, if your hook be once stuck into his chaps.

I told you that Sir Francis Bacon thinks that the carp lives but ten years: but Janus Dubravius has writ a book Of Fish and Fish-ponds, in which he says, that carps begin to spawn at the age of three years, and continue to do so till thirty: he says also, that in the time of their breeding, which is in summer, when the

* Lately, viz., in one of the daily papers for the month of August, 1782 , an article appeared, purporting that in the basin at Emanuel College, Cambridge, a carp was then living that had been in that water thirty-six years ; which, though it had lost one eye, knew, and would constantly approach, its feeder.-H. 
sun hath warmed both the earth and water, and so apted them also for generation, that then three or four male carps will follow a female; and that then, she putting on a seeming coyness, they force her through weeds and flags, where she lets fall her eggs or spawn, which sticks fast to the weeds; and then they let fall their melt upon it, and so it becomes in a short time to be a living fish : and, as I told you, it is thought that the carp does this several months in the year. And most believe that most fish breed after this manner, except the eel. And it has been observed, that when the spawner has weakened herself by doing that natural office, that two or three melters have helped her from off the weeds, by bearing her up on both sides, and guarding her into the deep. And you may note, that though this may seem a curiosity not worth observing, yet others have judged it worth their time and cost to make glass hives, and order them in such a manner as to see how bees have bred and made their honeycombs, and how they have obeyed their king, and governed their commonwealth. But it is thought that all carps are not bred by generation; but that some breed other ways, as some pikes do.

The physicians make the galls and stones in the heads of carps to be very medicinable. But it is not to be doubted but that in Italy they make great profit of the spawn of carps, by selling it to the Jews who make it into red caviare; the Jews not being by their law admitted to eat of caviare made of the sturgeon, that being a fish that wants scales-and, as may appear in Lev. xi. 10,--by them reputed to be unclean.

Much more might be said out of him, and out of Aristotle, which Dubravius often quotes in his Discourse of Fishes; but it might rather perplex than satisfy you: and therefore I shall rather choose to direct you how to catch, than spend more time in discoursing either of the nature or the breeding of this carp, or of any more 
circumstances concerning him; but yet I shall remember you of what I told you before, that he is a very subtle fish, and hard to be caught.

And my first direction is, that if you will fish for a carp, you must put on a very large measure of patience ; especially to fish for a river-carp; I have known a very good fisher angle diligently four or six hours in a day, for three or four days together, for a river-carp, and not have a bite. And you are to note, that in some ponds it is as hard to catch a carp as in a river;

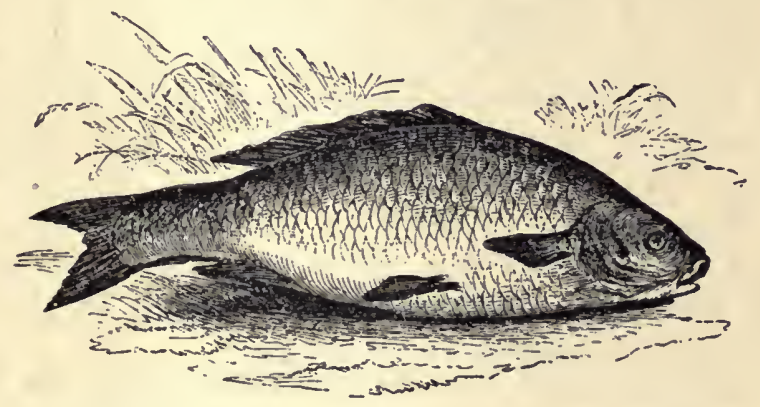

CARP

that is to say, where they have store of feed, and the water is of a clayish colour: but you are to remember I have told you there is no rule without an exception; and therefore being possessed with that hope and patience which I wish to all fishers, especially to the carp-angler, I shall tell you with what bait to fish for him. But first, you are to know, that it must be either early or late; and let me tell you, that in hot weather, for he will seldom bite in cold, you cannot be too early or too late at it. And some have been so curious as to say, the tenth of April is a fatal day for carps.

The carp bites either at worms or at paste; and of worms I think the bluish marsh or meadow-worm is 
best; but possibly another worm not too big may do as well, and so may a green gentle, and as for pastes, there are almost as many sorts as there are medicines for the toothache; but doubtless sweet pastes are best; I mean pastes made with honey or with sugar; which, that you may the better beguile this crafty fish, should be thrown in the pond or place in which you fish for him, some hours, or longer, before you undertake your trial of skill with the angle-rod; and doubtless, if it be thrown into the water a day or two before, at several times, and in small pellets, you are the likelier, when you fish for the carp, to obtain your desired sport. Or, in a large pond, to draw them to a certain place, that they may the better and with more hope be fished for, you are to throw into it, in some certain place, either grains or blood mixed with cow-dung or with bran; or any garbage, as chickens' guts, or the like; and then some of your small sweet pellets with which you purpose to angle: and these small pellets being a few of them also thrown in as you are angling, will be the better.

And your paste must be thus made: take the flesh of a rabbit or cat cut small; and bean-flour; and if that may not be easily got, get other flour; and then mix these together, and put to them either sugar, or honey (which I think better): and then beat these together in a mortar, or sometimes work them in youı hands, your hands being very clean; and then make it into a ball, or two, or three, as you like best, for your use : but you must work or pound it so long in the mortar, as to make it so tough as to hang upon your hook without washing from it, yet not too hard: or, that you may the better keep it on your hook, you may knead with your paste a little, and not much, white or yellowish wool.

And if you would have this paste keep all the year, for any other fish, then mix it with virgin-wax and clarified honey, and work them together with your hands before 
the fire; then make these into balls, and they will keep all the year.

And if you fish for a carp with gentles, then put upon your hook a little piece of scarlet, about this bigness $\mathbf{D}$ it being soaked in or anointed with oil of peter, called by some oil of the rock; and if your gentles be put two or three days before into a box or horn anointed with honey, and so put upon your hook as to preserve them to be living, you are as like to kill this crafty fish this way as any other: but still, as you are fishing, chew a little white or brown bread in your mouth, and cast it into the pond about the place where your float swims. Other baits there be; but these, with diligence and patient watchfulness, will do it better than any that I have ever practised or heard of : and yet I shall tell you, that the crumbs of white bread and honey, made into a paste, is a good bait for a carp ; and you know it is more easily made. And having said thus much of the carp,* my next discourse shall be of the bream; which shall not prove so tedious, and therefore I desire the continuance of your attention.

* The haunts of river carp are, in the winter months, the broadest and most quiet parts of the river; but in summer they lie in deep holes, nooks, and reaches, near some scour, and under roots of trees, hollow banks, and, till they are near rotting, amongst or near great beds of weeds, flags, etc. Pond carp cannot, with propriety, be said to have any haunts ; only it is to be noted, that they love a fat, rich soil, and never thrive in a cold, hungry water. They breed three or four times a year; but their first spawning-time is the beginning of May. Baits for the carp are all sorts of earth and dunghill worms, flag worms, grasshoppers (though not at top), ox brains, the pith of an ox's backbone, green peas, and red or black cherries with the stones taken out. Fish with strong tackle, very near the bottom, and with a fine grass or gut next the hook, and use a goosequill float. Never attempt to angle for the carp in a boat, for they will not come near it. It is said there are many carp in the Thames, westward of London, and that about February they retire to the creeks in that river; in some of which, many above two feet long have been taken with an angle. Carp live the longest out of the water of any fish. It is a common practice in Holland to keep them alive for three weeks or a month, by hanging them in a cool place, with wet moss, in a net, and feeding them with bread and milk.-H. 
But, first, I will tell you how to make this carp, that is so curious to be caught, so curious a dish of meat, as shall make him worth all your labour and patience; and though it is not without some trouble and charges, yet it will recompense both.

Take a carp, alive if possible, scour him, and rub him clean with water and salt, but scale him not; then open him, and put him, with his blood and his liver, which you must save when you open him, into a small pot or kettle; then take sweet marjoram, thyme, and parsley, of each half a handful, a sprig of rosemary, and another of savory, bind them into two or three small bundles, and put them to your carp, with four or five whole onions, twenty pickled oysters, and three anchovies. Then pour upon your carp as much claret wine as will only cover him, and season your claret well with salt, cloves and mace, and the rinds of oranges and lemons: that done, cover your pot and set it on a quick fire, till it be sufficiently boiled; then take out the carp, and lay it with the broth into the dish, and pour upon it a quarter of a pound of the best fresh butter, melted and beaten with half a dozen spoonfuls of the broth, the yolks of two or three eggs, and some of the herbs shred; garnish your dish with lemons, and so serve it up, and much good do you.-DR. T. 


\section{CHAPTER $\mathrm{X}$}

OBSẸRATIONS OF THE BREAM; AND DIRECTIONS TO CATCH HIM

\section{[fourtb Dav]}

Pisc. The Bream, being at a full growth, is a large and stately fish : he will breed both in rivers and ponds; but loves best to live in ponds, and where, if he likes the water and air, he will grow not only to be very large, but as fat as a hog: he is by Gesner taken to be more pleasant or sweet than wholesome: this fish is long in growing, but breeds exceedingly in a water that pleases him ; yea, in many ponds so fast as to overstore them, and starve the other fish.

$\mathrm{He}$ is very broad, with a forked tail, and his scales set in excellent order; he hath large eyes, and a narrow sucking mouth ; he hath two sets of teeth, and a lozengelike bone, a bone to help his grinding. The melter is observed to have two large melts; and the female, two large bags of eggs or spawn.

Gesner reports, that in Poland a certain and a great number of large breams were put into a pond, which in the next following winter were frozen up into one entire ice, and not one drop of water remaining, nor one of these fish to be found, though they were diligently searched for; and yet the next spring, when the ice was thawed, and the weather warm, and fresh water got into the pond, he affirms they all appeared again. This Gesner affirms; and I quote my author because it seems almost as incredible as the resurrection to an 
atheist : - but it may win something, in point of believing it, to him that considers the breeding or renovation of the silk-worm, and of many insects. And that is considerable, which Sir Francis Bacon observes in his History of Life and Death (fol. 20), that there be some herbs that die and spring every year, and some endure longer.

But though some do not, yet the French esteem this fish highly, and to that end have this proverb, "He that hath breams in his pond is able to bid his friend welcome."

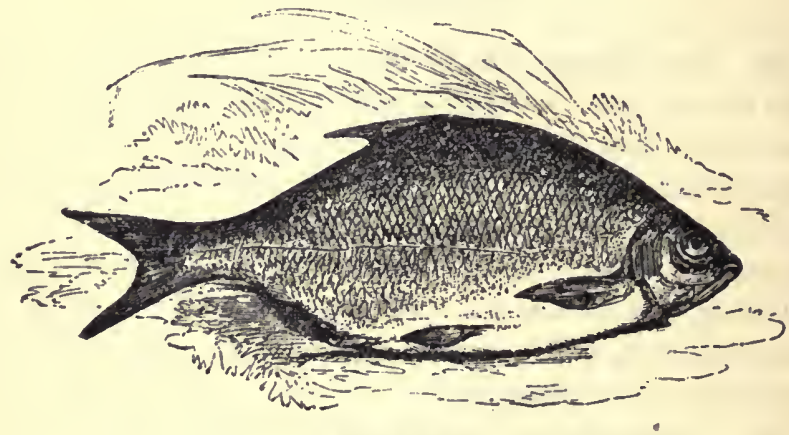

BREAM

And it is noted, that the best part of a bream is his belly and head.

Some say that breams and roaches will mix their eggs and melt together, and so there is in many places a bastard breed of breams, that never come to be either large or good, but very numerous.

The baits good to catch this bream are many. 1. Paste made of brown bread and honey, gentles, or the brood of wasps that be young, and then not unlike gentles, and should be hardened in an oven, or dried on a tile before the fire, to make them tough ; or there is at the root of docks or flags, or rushes in watery places, a worm not unlike a maggot, at which tench will bite freely. Or he will bite at a grasshopper with his legs nipped off, in June 
or July, or at several flies under water, which may be found on flags that grow near to the water-side. I doubt not but that there be many other baits that are good; but I will turn them all into this most excellent one, either for a carp or bream, in any river or mere : it was given to me by a most honest and excellent angler; and hoping you will prove both, I will impart it to you.

1. Let your bait be as big a red-worm as you can find, without a knot ; get a pint or quart of them in an evening in garden walks, or chalky common, after a shower of rain, and put them with clean moss well washed and picked, and the water squeezed out of the moss as dry as you can, into an earthen pot or pipkin set dry, and change the moss fresh every three or four days, for three weeks or a month together; then your bait will be at the best, for it will be clear and lively.

2. Having thus prepared your baits, get your tackling ready and fitted for this sport. Take three long angling rods, and as many and more silk, or silk and hair lines, and as many large swan or goose-quill floats. Then take a piece of lead made after this manner, and fasten them to the low ends of your lines; then

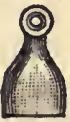
fasten your link-hook also to the lead, and let there be about a foot or ten inches between the lead and the hook; but be sure the lead be heavy enough to sink the float or quill a little under the water, and not the quill to bear up the lead, for the lead must lie on the ground. Note, that your link next the hook may be smaller than the rest of your line, if you dare adventure, for fear of taking the pike or perch, who will assuredly visit your hooks, till they be taken out, as I will shew you afterward, before either carp or bream will come near to bite. Note also, that when the worm is well baited, it will crawl up and down as far as the lead will give leave, which much enticeth the fish to bite without suspicion.

3. Having thus prepared your baits, and fitted your 
tackling, repair to the river, where you have seen them swim in skulls or shoals, in the summer time, in a hot afternoon, about three or four of the clock, and watch their going forth of their deep holes and returning, which you may well discern, for they return about four of the clock, most of them seeking food at the bottom, yet one or two will lie on the top of the water, rolling and tumbling themselves whilst the rest are under him at the bottom, and so you shall perceive him to keep sentinel; then mark where he plays most, and stays longest, which commonly is in the broadest and deepest place of the river, and there, or near thereabouts, at a clear bottom and a convenient landing-place, take one of your angles ready fitted as aforesaid, and sound the bottom, which should be about eight or ten feet deep, two yards from the bank is the best. Then consider with yourself whether that water will rise or fall by the next morning, by reason of any water-mills near, and according to your discretion take the depth of the place, where you mean after to cast your ground-bait, and to fish, to half an inch, that the lead lying on or near the ground-bait, the top of the float may only appear upright half an inch above the water.

Thus you having found and fitted for the place and depth thereof, then go home and prepare your groundbait, which is, next to the fruit of your labours, to be regarded.

\section{THE GROUND-BAIT}

You shall take a peck, or a peck and a half, according to the greatness of the stream and deepness of the watcr where you mean to angle, of sweet gross-ground barleymalt, and boil it in a kettle ; one or two warms is enough, then strain it through a bag into a tub, the liquor whereof hath often done my horse much good, and when the bag and malt is near cold, take it down to the water-side about cight or nine of the clock in the evening, and not before; 
cast in two parts of your ground-bait, squeezed hard between both your hands, it will sink presently to the bottom, and be sure it may rest in the very place where you mean to angle; if the stream run hard or move a little, cast your malt in handfuls a little the higher, upwards the stream. You may, between your hands, close the malt so fast in handfuls, that the water will hardly part it with the fall.

Your ground thus baited and tackling fitted, leave your bag with the rest of your tackling and ground-bait near the sporting-place all night, and in the morning about three or four of the clock, visit the water-side, but not too near, for they have a cunning watchman, and are watchful themselves too.

Then gently take one of your three rods, and bait your hook ; casting it over your ground-bait, and gently and secretly draw it to you till the lead rests about the middle of the ground-bait.

Then take a second rod, and cast in about a yard above, and your third a yard below the first rod; and stay the rods in the ground : but go yourself so far from the waterside, that you perceive nothing but the top of the floats, which you must watch most diligently. Then when you have a bite, you shall perceive the top of your float to sink suddenly into the water: yet, nevertheless, be not too hasty to run to your rods, until you see that the line goes clear away, then creep to the water-side, and give as much line as you possibly can : if it be a good carp or bream, they will go to the farther side of the river: then strike gently, and hold your rod at a bent, a little while; but if you both pull together, you are sure to lose your game, for either your line, or hook, or hold will break: and after you have overcome them, they will make noble sport, and are very shy to be landed. The carp is far stronger and more mettlesome than the bream.

Much more is to be observed in this kind of fish and 
fishing, but it is far better for experience and discourse than paper. Only, thus much is necessary for you to know, and to be mindful and careful of, that if the pike or perch do breed in that river, they will be sure to bite first, and must first be taken. And for the most part they are very large; and will repair to your ground-bait, not that they will eat of it, but will feed and sport themselves among the young fry that gather about and hover over the bait.

The way to discern the pike and to take him, if you mistrust your bream-hook,-for I have taken a pike a yard long several times at my bream-hooks, and sometimes he hath had the luck to share my line,-may be thus :

Take a small bleak, or roach, or gudgeon, and bait it, and set it alive among your rods two feet deep from the cork; with a little red worm on the point of the hook; then take a few crumbs of white bread, or some of the ground-bait, and sprinkle it gently amongst your rods. If Mr. Pike be there, then the little fish will skip out of the water at his appearance, but the live-set bait is sure to be taken.

Thus continue your sport from four in the morning till eight, and if it be a gloomy windy day, they will bite all day long. But this is too long to stand to your rods at one place, and it will spoil your evening sport that day, which is this :

About four of the clock in the afternoon repair to your baited place; and as soon as you come to the water-side, cast in one half of the rest of your ground-bait, and stand off : then whilst the fish are gathering together, for there they will most certainly come for their supper, you may take a pipe of tobacco; and then in with your three rods, as in the morning : you will find excellent sport that evening till eight of the clock; then cast in the residue of your ground-bait, and next morning by four of the clock visit 
them again for four hours, which is the best sport of all ; and after that, let them rest till you and your friends have a mind to more sport.

From St. James's-tide until Bartholomew-tide is the best; when they have had all the summer's food, they are the fattest.

Observe lastly, that after three or four days' fishing together your game will be very shy and wary, and you shall hardly get above a bite or two at a baiting; then your only way is to desist from your sport about two or three days ; and in the meantime, on the place you late baited, and again intend to bait, you shall take a tuft of green but short grass, as big or bigger than a round trencher; to the top of this turf, on the green side, you shall, with a needle and green thread, fasten one by one as many little red-worms as will near cover all the turf : then take a round board or trencher, make a hole in the middle thereof, and through the turf, placed on the board or trencher, with a string or cord as long as is fitting, tied to a pole, let it down to the bottom of the water, for the fish to feed upon without disturbance about two or three days; and after that you have drawn it away, you may fall to and enjoy your former recreation.*-B. A.

* The haunts of the bream, a fish which the angler seldom meets with, are the deepest and broadest parts of gentle, soft streams, with sandy, elayey bottoms; and the broadest and most quiet places of ponds, and where there are weeds. They spawn about the beginning of July ; a little before which time they are best in season, though some think them best in September. The baits for the bream are red worms, small lob or marsh worms, gentles, and grasshoppers. In general they are to be fished for as carp.-H. 


\section{CHAPTER XI}

\section{OBSERVATIONS ON THE TENCH; AND ADVICE HOW TO ANGLE FOR HIM}

\section{[Jfourtb Day]}

PIsc. The Tench, the physician of fishes, is observed to love ponds better than rivers, and to love pits better than either: yet Camden observes, there is a river in Dorsetshire that abounds with tenches, but doubtless they retire to the most deep and quiet places in it.

This fish hath very large fins, very small and smooth scales, a red circle about his eyes, which are big and of a gold colour, and from either angle of his mouth there hangs down a little barb. In every tench's head there are two little stones which foreign physicians make great use of, but he is not commended for wholesome meat, though there be very much use made of them for outward applications. Rondeletius says, that at his being at Rome, he saw a great cure done by applying a tench to the feet of a very sick man. This, he says, was done after an unusual manner, by certain Jews. And it is observed, that many of those people have many secrets yet unknown to Christians; secrets that have never yet been written, but have been (since the days of their Solomon, who knew the nature of all things, even from the cedar to the shrub) delivered by tradition, from the father to the son, and so from generation to generation, without writing; or (unless it were casually), without the least communicating them to any other nation or tribe; for to do that they account a profanation. And, yet, it is thought that 
they, or some spirit worse than they, first told us that lice swallowed alive, were a certain cure for the yellowjaundice. This, and many other medicines, were discovered by them, or by revelation; for, doubtless, we attained them not by study.

Well, this fish, besides his eating, is very useful both dead and alive for the good of mankind. But I will meddle no more with that; my honest humble art teaches no such boldness ; there are too many foolish meddlers in physic and divinity, that think themselves fit to meddle with hidden secrets, and so bring destruction to their

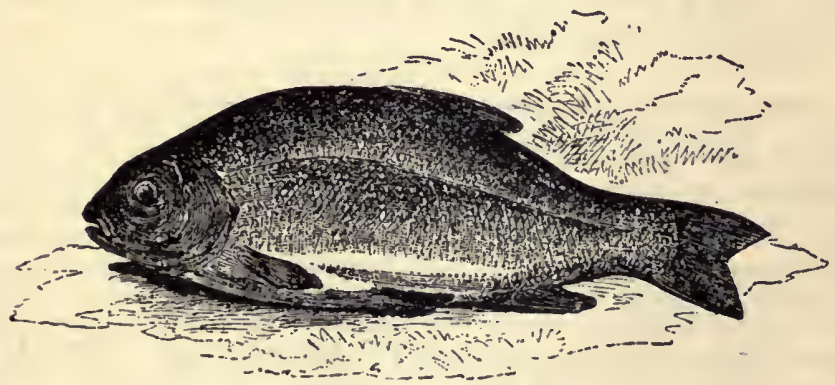

TENCH

followers. But I'll not meddle with them, any farther than to wish them wiser; and shall tell you next, for, I hope I may be so bold, that the tench is the physician of fishes, for the pike especially ; and that the pike, being either sick or hurt, is cured by the touch of the tench. And it is observed, that the tyrant pike will not be a wolf to his physician, but forbears to devour him though he be never so hungry.

This fish, that carries a natural balsam in him to cure himself and others, loves yet to feed in very foul water, and amongst weeds. And yet I am sure he eats pleasantly, and doubtless, you will think so too, if you taste him. And I shall therefore proceed to give you some few, and 
but a few, directions how to catch this tench, of which I have given you these observations.

He will bite a paste made of brown bread and honey, or at a marsh-worm, or a lob-worm; he inclines very much to any paste with which tar is mixed : and he will bite also at a smaller worm, with his head nipped off, and a cod-worm put on the hook before that worm; and I doubt not but that he will also in the three hot months,for in the nine colder he stirs not much,-bite at a flagworm, or at a green gentle; but I can positively say no more of the tench,* he being a fish $\mathrm{I}$ have not often angled for; but I wish my honest scholar may, and be ever fortunate when he fishes.

* The haunts of the tench are nearly the same with those of the carp. They delight more in ponds than in rivers; and lie under weeds, near sluices, and at pond-heads. They spawn about the beginning of July; and are best in season from the beginning of September to the end of May. They will bite all the hot months; but are taken best in April and May. There are no better baits for this fish than a middle-sized lob-worm, or red-worm, well scoured; a gentle; a young wasp grub, boiled; or a green worm shook from the boughs of trees. Use a strong grass, or gut; and a goose-quill float without a cork, except in rivers, where the cork is always to be preferred. Fish very near the ground. And if you bait with gentles, throw in a few at the taking every fish, which will draw them to your hook, and keep them together. $-\mathrm{H}$. 


\section{CHAPTER XII}

OBSERVATIONS ON THE PERCH; AND DIRECTIONS HOW TO FISH FOR HIM

\section{[Jfourtb פay]}

PIsc. The Perch is a very good and a very bold biting fish. He is one of the fishes of prey that, like the pike and trout, carries his teeth in his mouth, which is very large: and he dare venture to kill and devour several other kinds of fish. He has a hooked or hog back, which is armed with sharp and stiff bristles, and all his skin armed or covered over with thick dry hard scales, and hath, which few other fish have, two fins on his back. $\mathrm{He}$ is so bold that he will invade one of his own kind, which the pike will not do willingly, and you may therefore easily believe him to be a bold biter.

The perch is of great esteem in Italy, saith Aldrovandus, and especially the least are there esteemed a dainty dish. And Gesner prefers the perch and pike above the trout, or any fresh-water fish: he says the Germans have this proverb, "More wholesome than a perch of Rhine"; and he says the river perch is so wholesome that physicians allow him to be eaten by wounded men, or by men in fevers, or by women in childbed.

He spawns but once a year, and is, by physicians, held very nutritive; yet, by many, to be hard of digestion. They abound more in the River Po, and in England, says Rondeletius, than other parts, and have in their brain a stone which is in foreign parts sold by apothe- 
caries, being there noted to be very medicinable against the stone in the reins. These be a part of the commendations which some philosophical brains have bestowed upon the fresh-water perch; yet they commend the sea-perch, which is known by having but one fin on his back,- - of which, they say, we English see but a few, to be a much better fish.

The perch grows slowly, yet will grow, as I have been credibly informed, to be almost two foot long; for an honest informer told me such a one was not long since taken by Sir Abraham Williams, a gentleman of worth, and a brother of the angle, that yet lives, and I wish he may : this was a deep bodied fish, and doubtless durst have devoured a pike of half his own length; for I have told you he is a bold fish, such a one as, but for extreme hunger, the pike will not devour; for to affright the pike, and save himself, the perch will set up his fins, much like as a turkey-cock will sometimes set up his tail.

But, my scholar, the perch is not only valiant to defend himself, but he is, as I said, a bold-biting fish, yet he will not bite at all seasons of the year; he is very abstemious in winter, yet will bite then in the midst of the day, if it be warm : and note, that all fish bite best about the midst of a warm day in winter, and he hath been observed by some not usually to bite till the mulberry-tree buds, that is to say, till extreme frosts be past the spring, for when the mulberry-tree blossoms many gardeners observe their forward fruit to be past the danger of frosts, and some have made the like observation of the perch's biting.

But bite the perch will, and that very boldly : and as one has wittily observed, if there be twenty or forty in a hole, they may be at one standing all catched one after another, they being, as he says, like the wicked of the world, not afraid, though their fellows and com- 
panions perish in their sight. And you may observe, that they are not like the solitary pike, but love to accompany one another, and march together in troops.

And the baits for this bold fish are not many; I mean, he will bite as well at some or at any of these three, as at any, or all others whatsoever, a worm, a minnow, or a little frog, of which you may find many in liay-time; and of worms, the dunghill-worm, called a brandling, I take to be best, being well scoured in moss or fennel; or he will bite at a worm that lies under cow-dung, with a bluish head. And if you rove for a perch with a minnow, then it is best to be alive, you sticking your hook through his back-fin, or a minnow with the hook in his upper lip, and letting him swim up and down about mid-water, or a little lower, and you still keeping him to about that depth by a cork, which ought not to be a very little one; and the like way you are to fish for the perch, with a small frog, your hook being fastened through the skin of his leg, towards the upper part of it; and lastly, I will give you but this advice, that you give the perch time enough when he bites, for there was scarce ever any angler that has given him too much. And now I think best to rest myself, for I have almost spent my spirits with talking so long.

VEN. Nay, good master, one fish more, for you see it rains still, and you know our angles are like money put to usury, they may thrive, though we sit still, and do nothing but talk and enjoy one another. Come, come, the other fish, good master.

PIsc. But, scholar, have you nothing to mix with this discourse, which now grows both tedious and tiresome? shall I have nothing from you, that seem to have both a good memory, and a cheerful spirit ?

VEN. Yes, master, I will speak you a copy of verses that were made by Doctor Donne, and made to shew the world that he could make soft and smooth verses 
when he thought smoothness worth his labour; and I love them the better because they allude to rivers, and fish and fishing. They be these :-

Come live with me, and be my love, And we will some new pleasures prove, of golden sands and crystal brooks, With silken lines and silver hooks.

There will the river whisp'ring run, Warm'd by thy eyes more than the sun; And there th' enamell'd fish will stay, Begging themselves they may betray.

When thou wilt swim in that live bath, Each fish, which every channel hath, Most amorously to thee will swim, Gladder to catch thee, than thou him.

If thou to be so seen be'st loath, By sun or moon, thou darkenest both ; And if mine eyes have leave to see, I need not their light, having thec.

Let others freeze with angling-reeds, And cut their legs with shells and weeds, Or treacherously poor fish beset With strangling snares, or windowy net:

Let coarse bold hands, from slimy nest, The bedded fish in banks outwrest; Let curious traitors sleave silk flies, To 'witch poor wandering fishes' eyes :

For thee, thou need'st no such deceit, For thou thyself art thine own bait: That fish that is not catch'd thereby Is wiser far, alas! than I.

Pisc. Well remembered, honest scholar; I thank you for these choice verses, which I have heard formerly, hut had quite forgot, till they were recovered by your 
happy memory. Well, being I have now rested myself a little, I will make you some requital, by telling you some observations of the eel, for it rains still, and because, as you say, our angles are as money put to use, that thrives when we play, therefore we'll sit still and enjoy ourselves a little longer under this honeysuckle hedge.*

* Although perch, like trout, delight in clear swift rivers, with pebbly, gravelly bottoms, they are often found in sandy, clayey soils; they love a moderately deep water, and frequent holes by the sides of or near little streams, and the hollows under banks. The perch spawns about the beginning of March: the best time of the year to angle for him is from the beginning of May till the end of June, yet you may continue to fish for him till the end of September; he is best taken in cloudy, windy weather, and, as some say, from seven to ten in the forenoon, and from two to seven in the afternoon. Other baits for the perch are loaches, miller's thumbs, stickle-backs ; small-lob, and marsh, and red-worms, well scoured; horse-beans, boiled; cad-bait, oak-worms, bobs, and gentles. Many of these fish are taken in the rivers about Oxford; and the author of the Angler's Sure Guide says he once saw the figure of a perch, drawn with a pencil on the door of a house near that city, which was twenty-nine inches long; and was informed it was the true dimensions of a living perch (Angler's Sure Guide, p. 155). The largest perch are taken with a minnow, hooked with a good hold through the upper lip ; for the perch, by reason of the figure of his mouth, cannot take the bait crosswise, as the pike will. When you fish thus, use a large cork float, and lead your line about nine inches from the bottom, otherwise the minnow will come to the top of the water ; but in the ordinary way of fishing, let your bait hang within about six inches of the ground. $-\mathrm{H}$. 


\section{CHAPTER XIII}

OBSERVATIONS OF THE EEL, AND OTHER FISH THAT WANT SCALES ; AND HOW TO FISH FOR THEM

\section{[Jfourtb Day]}

PISc. It is agreed by most men, that the Eel is a most dainty fish; the Romans have esteemed her the Helena of their feasts, and some the queen of palate-pleasure. But most men differ about their breeding: some say they breed by generation as other fish do, and others, that they breed, as some worms do, of mud; as rats and mice, and many other living creatures are bred in Egypt, by the sun's heat, when it shines upon the overflowing of the River Nilus : or out of the putrefaction of the earth, and divers other ways. Those that deny them to breed by generation as other fish do, ask, if any man ever saw an eel to have a spawn or melt ? and they are answered, that they may be as certain of their breeding as if they had seen spawn : for they say, that they are certain that eels have all parts fit for generation, like other fish,*

* That fishes are furnished with parts fit for generation cannot be doubted, since it is a common practice to castrate them. See the method of doing it in Philos. Trans. vol. xlviii. part ii., for the year 1754 , page 870 . - H.

[I am surprised at the anatomical ignorance of Sir J. Hawkins, and at that of the writer in the Philosophical Transactions. No riverfish have external organs of generation, and cannot therefore be castrated. Eels have ova and milt like other fresh-water fish, but in minute portions. They are migratory in rivers running into the sea. They migrate to deposit their spawn in salt water, and Immigrate to fresh water to grow in it. The salmon migrates to sea for a different purpose-to grow and fatten in salt water; and immigrates to fresh to procreate its species in the shallows. I am of opinion that eels are oviparous, and I know, of my own know- 
but so small as not to be easily discerned, by reason of their fatness; but that discerned they may be ; and that the he and the she-eel may be distinguished by their fins. And Rondeletius says he has seen eels cling together like dew-worms.

And others say, that eels, growing old, breed other eels out of the corruption of their own age; which, Sir Francis Bacon says, exceeds not ten years. And others say, that as worms are made of glutinous dew-drops, which are condensed by the sun's heat in those countries, so eels are bred of a particular dew, falling in the months of May or June on the banks of some particular ponds or rivers, apted by nature for that end; which in a few days are, by the sun's heat, turned into eels; and some of the ancients have called the eels that are thus bred the offspring of Jove. I have seen, in the beginning of July, in a river not far from Canterbury, some parts of it covered over with young eels, about the thickness of a straw; and these eels did lie on the top of that water, as thick as motes are said to be in the sun; and I have heard the like of other rivers, as namely, in Severn, where they are called yelvers; and in a pond, or mere, near unto Staffordshire, where, about a set time in summer, such small eels abound so much that many of the poorer sort of people that inhabit near to it, take such eels out of this mere with sieves or sheets; and make a kind of eel-cake of them, and eat it like as bread. And Gesner quotes Venerable Bede,* to say, that in England there is an island called Ely, by reason of the innumerable number of eels that breed in it. But that eels may be bred as some worms, and some kind of bees and wasps are, ledge, that Mr. Andrew Young, of Invershin, Sutherlandsh're, has bred them artificially from impregnated spawn, procured from living inale and female specimens.-E.]

* The most universal scholar of his time : he was born at Durham about 671 , and bred under St. John of Beverley. He was a man of great virtue, and remarkable for a most sweet and engaging disposition : he died 734, and lies buried at Durham. 
either of dew, or out of the corruption of the earth, seems to be made probable by the barnacles and young goslings bred by the sun's heat and the rotten planks of an old ship, and hatched of trees; both which are related for truths by Du Bartas and Lobel,* and also by our learned Camden, and laborious Gerard, $\dagger$ in his Herbal.

It is said by Rondeletius, that those eels that are bred in rivers that relate to or be nearer to the sea, never return to the fresh waters (as the salmon does always desire to do), when they have once tasted the salt water; and I do the more easily believe this, because I am certain that powdered beef is a most excellent bait to catch an eel. And though Sir Francis Bacon will allow the eel's life to be but ten years, yet he, in his History of Life and Death, mentions a lamprey belonging to the Roman emperor, to be made tame, and so kept for almost threescore years; and that such useful and pleasant observations were made of this lamprey, that Crassus the orator, who kept her, lamented her death. And we read in Doctor Hakewill, that Hortensius was seen to weep at the death of a lamprey that he had kept long and loved exceedingly. $\neq$

* Matthias de Lobel, or L'Obel, an eminent physician and botanist of the sixteenth century, was a native of Lisle, in Flanders. He was a disciple of Rondeletius, and, being invited to London by King James the First, published there his Historia Plantarum, and died in the year 1616. He was the author of several books connected with medico-botany.

t The person here mentioned is John Gerard, the first of our English botanists : he was by profession a surgeon; and published, in 1597, a Herbal, in a large folio, dedicated to the lord treasurer Burleigh; and, two years after, a Catalogue of Plants, Herbs, etc., to the number of eleven hundred, raised and naturalised by himself in a large garden near his house in Holborn. The latter is dedicated to Sir Walter Raleigh.

¥ The author, vol. i. p. 212, has cited from Pliny an instance of the fondness of Antonia, a woman, for a tame lamprey, which the tenderness of her sex might perhaps excuse; but the sagacity and docility of these creatures seem less wonderful than the weakness of such inen as Crassus and Hortensius, in becoming mourners for the death of an eel. The former of these two persons was, for this his pusillanimity, reproached in the senate of Rome by Domitius, in 
It is granted by all, or most men, that eels, for about six months, that is to say, the six cold months of the year, stir not up and down, neither in the rivers, nor in the pools in which they usually are, but get into the soft earth or mud; and there many of them together bed themselves, and live without feeding upon anything, as I have told you some swallows have been observed to do in hollow trees, for those cold six months ; and this the eel and swallow do, as not being able to endure winter weather : for Gesner quotes Albertus to say, that in the year 1125, that year's winter being more cold than usually, eels did by nature's instinct get out of the water into a stack of hay in a meadow upon dry ground, and there bedded themselves, but yet at last a frost killed them. And our Camden relates, that in Lancashire fishes were digged out of the earth with spades, where no water was near to the place. I shall say little more of the eel, but that, as it is observed, he is impatient of cold; so it hath been observed, that in warm weather an eel has been known to live five days out of the water.

And lastly, let me tell you that some curious searchers into the natures of fish observe, that there be several sorts or kinds of eels, as the silver eel, and green or greenish eel, with which the River of Thames abounds, and those are called grigs ; and a blackish eel, whose head is more flat and bigger than ordinary eels; and also an eel whose fins are reddish, and but seldom taken in this nation, and yet taken sometimes : these several kinds of eels are, say some, diversely bred; as namely, out of the corruption of the earth, and some by dew, and other ways, as I have said to you : and yet it is affirmed by some for certain, that the silver eel is bred by generation, but not by spawning as other fish do, but that her brood

these words: "Foolish Crassus! you wept for your muræna" (or lamprey). " "That is more," retorted Crassus," than you did for your two wives." (Lord Bacon's Apophthegms.)-H. 
come alive from her, being then little live eels, no bigger nor longer than a pin: and I have had too many testimonies of this to doubt the truth of it myself; and if I thought it needful I might prove it, but I think it is needless.

And this eel, of which I have said so much to you, may be caught with divers kinds of baits; as namely, with powdered beef, with a lob or garden-worm, with a minnow, or gut of a hen, chicken, or the guts of any fish, or with almost anything, for he is a greedy fish :* but the eel may be caught especially with a little, a very little lamprey, which some call a pride, and may in the hot months be found many of them in the River Thames, and in many mud-heaps in other rivers, yea, almost as usually as one finds worms in a dunghill.

Next note, that the eel seldom stirs in the day, but then hides himself; and therefore he is usually caught by night, with one of these baits of which I have spoken : and may be then caught by laying hooks, which you are to fasten to the bank, or twigs of a tree; or by throwing a string across the stream with many hooks at it, and those baited with the aforesaid baits, and a clod, or plummet, or stone, thrown into the river with this line, that so you may in the morning find it near to some fixed place; and then take it up with a drag-hook, or otherwise. But these things are, indeed, too common to be spoken of ; and an hour's fishing with an angler

* To this truth I myself can bear witness. When I dwelt at Twickenham, a large canal adjoined to my house, which I stocked with fish. I had from time to time broods of ducks, which, with their young ones, took to the water. One dry summer, when the canal was very low, we missed many young ducks, but could not find out how they went. Resolving to take advantage of the lowness of the water to clean the canal, a work which had not been done for thirty years before, I drained and emptied it, and found in the mud a great number of large cels. Some of them I reserved for the use of my family; which being opened by the cook surprised us all ; for in the stomachs of several of them were found, undigested, the necks and heads of young ducks, which doubtless were those of the ducks we had missed.- $-\mathrm{H}$. 
will teach you better, both for these and many other common things in the practical part of angling, than a week's discourse. I shall therefore conclude this direction for taking the eel, by telling you, that in a warm day in summer I have taken many a good eel by snigling, and have been much pleased with that sport.

And because you, that are but a young angler, know not what snigling is, I will now teach it to you. You remember, I told you, that eels do not usually stir in the day time; for then they hide themselves under some

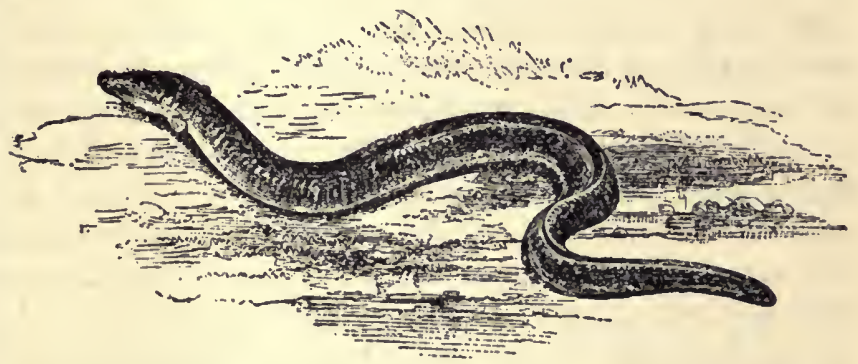

THE EEL

covert; or under boards or planks about flood-gates or weirs or mills; or in holes on the river banks : so that you, observing your time in a warm day, when the water is lowest, may take a strong small hook, tied to a strong line, or to a string about a yard long ; and then into one of these holes or between any boards about a mill or under any great stone or plank or any place where you think an eel may hide or shelter herself, you may, with the help of a short stick, put in your bait, but leisurely, and as far as you may conveniently ; and it is scarce to be doubted, but if there be an eel, within the sight of it, the eel will bite instantly, and as certainly gorge it; and you need not doubt to have him if you pull him not out of the hole too quickly, but pull him out by degrees ; for he, lying folded 
double in his hole, will, with the help of his tail, break all, unless you give him time to be wearied with pulling; and so get him out by degrees, not pulling too hard.

And to commute for your patient hearing this long direction, I shall next tell you how to make this eel a most excellent dish of meat.

First, wash him in water and salt, then pull off his skin below his vent or navel, and not much further; having done that, take out his guts as clean as you can, but wash him not: then give him three or four scotches with a knife, and then put into his belly and those scotches, sweet herbs, an anchovy, and a little nutmeg grated, or cut very small; and your herbs and anchovies must also be cut very small, and mixed with good butter and salt : having done this, then pull his skin over him all but his head, which you are to cut off, to the end you may tie his skin about that part where his head grew ; and it must be so tied as to keep all his moisture within his skin : and having done this, tie him with tape or packthread to a spit, and roast him leisurely, and baste him with water and salt till his skin breaks, and then with butter; and having roasted him enough, let what was put into his belly and what he drips, be his sauce.-S. F.

When I go to dress an eel thus, I wish he were as long and big as that which was caught in Peterborough river in the year 1667, which was a yard and three quarters long. If you will not believe me, then go and see at one of the coffee-houses in King Street, in Westminster.

But now let me tell you, that though the eel thus dressed be not only excellent good, but more harmless than any other way; yet it is certain, that physicians account the eel dangerous meat: I will advise you therefore, as Solomon says of honey, "Hast thou found it, eat no more than is sufficient, lest thou surfeit; . for it is not good to eat much honey." And let me add this, that the 
uncharitable Italian bids us " give eels and no wine to our enemies."

And I will beg a little more of your attention to tell you, Aldrovandus, and divers physicians, commend the eel very much for medicine, though not for meat. But let me tell you one observation, that the eel is never out of season ; as trouts, and most other fish are at set times : at least most eels are not.*

* The liaunts of the eel are, weeds, under roots, stumps of trees, holes, and clefts of the earth, both in the banks and at the bottom, and in the plain mud, where they lie with only their heads out, watching for prey. They are also found under great stones, old timber, about flood-gates, weirs, bridges, and old mills. They delight in still waters, and in those that are foul and muddy; though the smaller eels are to be met with in all sorts of rivers and soils. Although the manner in which eels, and indeed all fish, are generated, is sufficiently settled, as appears by the foregoing notes; there yet remains a question undecided by naturalists; and that is, Whether the eel be an oviparous or a viviparous fish? Walton inclines to the latter opinion. The following relation from Bowlker may go near to determine the question: " Being acquainted with an elderly woman, who had been wife to a miller near fifty years, and much employed in dressing of eels, I asked her if she had ever found any spawn or eggs in those eels she opened? She said she had never observed any; but that she had sometimes found living eels in them, about the bigness of a small needle ; and particularly, that she once took out ten or twelve, and put them upon the table, and found them to be alive; which was confirmed to me by the rest of the family. The time of the year when this happened was, as they informed me, about a fortnight or three weeks after Michaelmas; which makes me of opinion that they go down to the sea, or saltwater, to prepare themselves for the work of propagating and producing their young. To this I must add another observation of the same nature, that was made by a gentleman of fortune not far from Ludlow, and in the commission of the peace for the county of Salop; who going to visit a gentleman, his friend was shown a very fine large eel that was going to be dressed, about whose sides and belly he observed a parcel of little creeping things, which at first made him suspect it had been kept too long; but upon nearer inspection, they were found to be perfect little eels, or elvers. Upon this it was immediately opened in the sight of several other gentlemen, and, in the belly of it, they found a lump about as big as a nutmeg, consisting of an infinite number of those little creatures closely wrapped up together; which, being put into a basin of water, soon separated, and swam about the basin. This he has often told to several gentlemen of credit in his neighbourhood, from some of whom I first received this account: but I have lately had the satisfaction of having it from his own mouth, and therefore I think this may serve to put the matter out of all doubt, and may 
I might here speak of many other fish, whose shape and nature are much like the eel, and frequent both the sea and fresh ivers ; as namely, the lamprel, the lamprey, and the lamperne : as also of the mighty conger, taken often in Severn, about Gloucester : and might also tell in what high esteem many of them are for the curiosity of their taste. But these are not so proper to be talked of by me, because they make us anglers no sport; therefore I will let them alone, as the Jews do, to whom they are forbidden by their law.

And, scholar, there is also a Flounder, a sea-fish which will wander very far into fresh rivers, and there lose himself and dwell : and thrive to a hand's breadth, and almost twice so long: a fish without scales, and most excellent meat: and a fish that affords much sport to the angler, with any small worm, but especially a little bluish worm gotten out of marsh-ground or meadows, which should be well scoured.* But this, though it be

be sufficient to prove that eels are of the viviparous kind." Taking it for granted then that eels do not spawn, all we have to say in this place is, that though, as our author tells us, they are never out of season, yet, as some say, they are best in winter, and worst in May: and it is noted to be of eels, that the longer they live the better they are (Angler's Sure Guide, p. 164). Of baits for the eel, the best are lob-worms, loach, minnows, small pope or perch with the fins cut off, pieces of any fish, especially bleak, as being very lueid, with which I have taken very large ones. As the angling for eels is no very pleasant amusement, and is always attended with great trouble and the risk of tackle, many, while they angle for other fish, lay lines for the eel, which they tie to weeds, flags, ete., with marks to find them by ; or you may take a long packthread-line, with a leaden weight at the end, and hooks looped on at a yard distance from each other : fasten one end to the flags, or on the shore, and throw the lead out, and let the line lie some time; and in this way you may probably take a pike.-H.

* The taking flounders with a rod and line is a thing so accidental, that it is hardly worth the mention. The same may be said of smelts, which, in the Thames, and other great rivers, are eaught with a bit i $f$ any small fish, but ehiefly of their own species. In the month of August, about the year 1720, such vast quantities of sinelts came up the Thames, that women, and even children became anglers for them ; and as I have been told by persons who well remember it, in one day, between London Bridge and Greenwich, not fewer than two thousand persons were thus emplnyed.-H. 
most excellent meat, yet it wants scales, and is, as I told you, therefore an abomination to the Jews.

But, scholar, there is a fish that they in Lancashire boast very much of, called a Char ; taken there (and I think there only), in a mere called Winander Mere ; a mere, says Camden, that is the largest in this nation, being ten miles in length, and (some say) as smooth in the bottom as if it were paved with polished marble. This fish never exceeds fifteen or sixteen inches in length; and is spotted like a trout : and has scarce a bone, but on the back. But this, though I do not know whether it make the angler sport, yet I would have you take notice of it, because it is a rarity, and of so high esteem with persons of great note.

Nor would I have you ignorant of a rare fish called a Guiniad; of which I shall tell you what Camden and others speak. The River Dee (which runs by Chester), springs in Merionethshire; and, as it runs toward Chester, it runs through Pemble Mere, which is a large water: and it is observed, that though the River Dee abounds with salmon, and Pemble Mere with the guiniad, yet there is never any salmon caught in the mere, nor a guiniad in the river. And now my next observation shall be of the barbel. 


\section{CHAPTER XIV}

OBSERVATIONS OF THE BARBEL; AND DIRECTIONS HOW TO FISH FOR HIM

\section{[jourtb פay]}

Pisc. The Barbel is so called, says Gesner, by reason of his barb or wattles at his mouth, which are under his nose or chaps. He is one of those leather-mouthed fishes, that I told you of, that does very seldom break his hold if he be once hooked : but he is so strong, that he will often break both rod and line, if he proves to be a big one.

But the barbel, though he be of a fine shape, and looks big, yet he is not accounted the best fish to eat, neither for his wholesomeness nor his taste: but the male is reputed much better than the female, whose spawn is very hurtful, as I will presently declare to you.

They flock together, like sheep, and are at the worst in April, about which time they spawn, but quickly grow to be in season. He is able to live in the strongest swifts of the water, and in summer they love the shallowest and sharpest streams; and love to lurk under weeds, and to feed on gravel against a rising ground, and will root and dig in the sands with his nose like a hog, and there nest himself : yet sometimes he retires to deep and swift bridges, or flood-gates, or weirs, where he will nest himself amongst piles, or in hollow places, and take such hold of moss or weeds, that be the water never so swift, it is not able to force him from the place that he contends for. This is his constant custom in summer, when he and most living creatures sport themselves in the sun : but at 
the approach of winter, then he forsakes the swift streams and shallow waters, and by degrees retires to those parts of the river that are quiet and deeper : in which places, and I think about that time, he spawns, and, as I have formerly told you, with the help of the melter, hides his spawn or eggs in holes, which they both dig in the gravel, and then they mutually labour to cover it with the same sand, to prevent it from being devoured by other fish.

There be such store of this fish in the River Danube, that Rondeletius says, they may in some places of it, and in some months of the year, be taken by those that dwell near to the river, with their hands, eight or ten load at a time : he says, they begin to be good in May, and that they cease to be so in August; but it is found to be otherwise in this nation: but thus far we agree with him, that the spawn of a barbel, if it be not poison, as he says, yet that it is dangerous meat, and especially in the month of May; which is so certain, that Gesner and Gasius declare it had an ill effect upon them, even to the endangering of their lives.*

This fish is of a fine cast and handsome shape, with small scales, which are placed after a most exact and curious manner, and, as I told you, may be rather said not to be ill, than to be good meat: the chub and he have, I think, both lost part of their credit by ill cookery, they being reputed the worst or coarsest of fresh-water fish. But the barbel affords an angler choice sport, being a lusty and a cunning

* Though the spawn of the barbel is known to be of a poisonous nature, yet it is often taken by country people medicinally: who find it at once, a most powerful emetic and carthartic. And, notwithstanding what is said of the wholesomeness of the flesh, with some constitutions it produces the same effects as the spawn. About the month of September, in the year 1574, a servant of mine, who had eaten part of a barbel, though, as I had cautioned him, he abstained from the spawn, was seized with such violent purging and vomiting, as had like to have cost him his life.-H.

[NotE.-I doubt very much the truth of the alleged noxious properties eitlier of the roe or the flesh of barbel when in condition, in the month of July, August, September, and October. Their edible qualities are bad-that is, tasteless.-E.] 
fish; so lusty and cunning as to endanger the breaking of the angler's line, by running his head forcibly towards any covert or hole or bank, and then striking at the line, to break it off, with his tail, as is observed by Plutarch in his book De Industriâ Animalium ; and also so cunning, to nibble and suck off your worm close to the hook, and yet avoid the letting the hook come into his mouth.

The barbel is also curious for his baits; that is to say, that they be clean and sweet; that is to say, to have your worms well scoured, and not kept in sour and musty moss, for he is a curious feeder; but at a well scoured lob-worm he will bite as boldly as at any bait, and especially

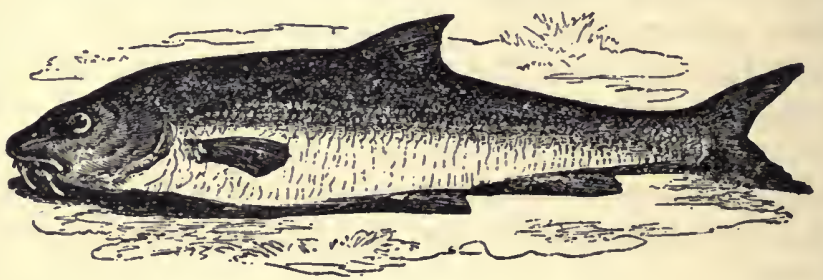

BARBEI

if, the night or two before you fish for him, you shall bait the places where you intend to fish for him, with big worms cut into pieces; and note, that none did ever overbait. the place, nor fish too early or too late for a barbel. And the barbel will bite also at gentles, which not being too much scoured, but green, are a choice bait for him; and so is cheese, which is not to be too hard, but kept a day or two in a wet linen cloth to make it tough : with this you may also bait the water a day or two before you fish for the barbel, and be much the likelier to catch store : and if the cheese were laid in clarified honey a short time before, as namely, an hour or two, you are still the likelier to catch fish : some have directed to cut the cheese into thin pieces, and toast it; and then tie it on the hook with fine silk : and 
some advise to fish for the barbel with sheep's tallow and soft cheese beaten or worked into a paste, and that it is choicely good in August, and I believe it; but doubtless the lob-worm well scoured, and the gentle not too much scoured; and cheese ordered as I have directed, are baits enough, and I think will serve in any month, though I shall commend any angler that tries conclusions, and is industrious to improve the art. And now, my honest scholar, the long shower and my tedious discourse are both ended together; and I shall give you but this observation, that when you fish for barbel, your rod and line be both long and of good strength, for, as I told you, you will find him a heavy and a dogged fish to be dealt withal, yet he seldom or never breaks his hold if he be once strucken. And if you would know more of fishing for the umber or barbel, get into favour with Doctor Sheldon, whose skill is above others; and of that the poor that dwell about him have a comfortable experience.

And now let us go and see what interest the trouts will pay us for letting our angle-rods lie so long and so quietly in the water, for their use. Come, scholar, which will you take up ?

VEN. Which you think fit, master.

Pisc. Why, you shall take up that, for I am certain, by viewing the line, it has a fish at it. Look you, scholar! well done! Come, now take up the other too: well! now you may tell my brother Peter, at night, that you have caught a leash of trouts this day. And now let's move towards our lodging, and drink a draught of red cow's milk as we go ; and give pretty Maudlin and her honest mother a brace of trouts for their supper.

Ven. Master, I like your motion very well ; and I think it is now about milking-time; and yonder they be at it.

PISC. God speed you, good woman! I thank you both for our songs last night: I and my companion have had 
such fortune a-fishing this day, that we resolve to give you and Maudlin a brace of trouts for supper; and we will now taste a draught of your red cow's milk.

MiLk-W. Marry, and that you shall with all my heart ; and I will still be your debtor when you come this way. If you will but speak the word, I will make you a good syllabub of new verjuice; and then you may sit down in a haycock, and eat it; and Maudlin shall sit by and sing you the good old song of the "Hunting in Chevy Chace," or some other good ballad, for she hath store of them; Maudlin, my honest Maudlin, hath a notable memory, and she thinks nothing too good for you, because you be such honest men.

VeN. We thank you; and intend, once in a month, to call upon you again, and give you a little warning; and so, good night; good night, Maudlin. And now, good master, let's lose no time: but tell me somewhat more of fishing; and, if you please, first, something of fishing for a gudgeon.

Pisc. I will, honest scholar. 


\section{CHAPTER XV}

OBSERVATIONS OF THE GUDGEON, THE RUFFE, AND THE BLEAK; AND HOW TO FISH FOR THEMI

\section{[jourtb Day]}

Pisc. The Gudgeon is reputed a fish of excellent taste, and to be very wholesome : he is of a fine shape, of a silver

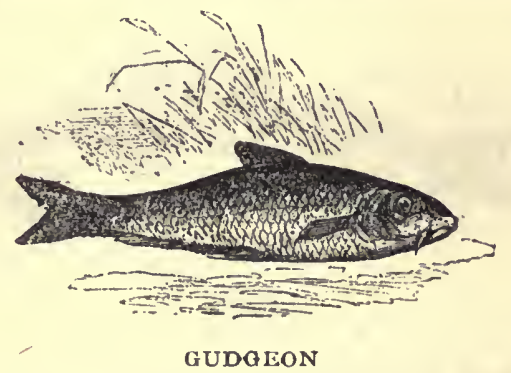

colour, and beautified with black spots both on his body and tail. He breeds two or three times in the year, and always in summer. He is commended for a fish of excellent nourishment: the Germans call him groundling, by reason of his feeding on the ground; and he there feasts himself in sharp streams, and on the gravel. He and the barbel both feed so, and do not hunt for flies at any time, as most other fishes do ; he is a most excellent fish to enter a young angler, being easy to be taken with a small red-worm, on or near to the ground. He is one of those leather-mouthed fish that has his teeth in his throat, and will hardly be lost off from the hook if he be once strucken.

They be usually scattered up and down every river in $100-\mathrm{G}$ 
the shallows, in the heat of summer; but in autumn, when the weeds begin to grow sour and rot, and the weather colder, then they gather together, and get into the deep parts of the water, and are to be fished for there, with your hook always touching the ground, if you fish for him with a float, or with a cork; but many will fish for the gudgeon by hand, with a running-line upon the ground, without a cork, as a trout is fished for; and it is an excellent way, if you have a gentle rod and as gentle a hand.*

There is also another fish called a Pope, and by some

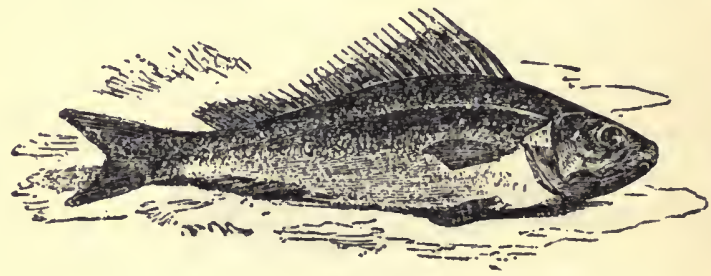

RUFFE

a Ruffe, a fish that is not known to be in some rivers: he is much like the perch for his shape, and taken to be better than the perch, but will not grow to be bigger

* In fisling for gudgcon, have a rake, and every quarter of an hour rake the bottom of the river, and the fish will flock thither in shoals. - $\mathrm{H}$.

[This note of Sir J. Hawkins is imperfect and obscure. In fishing for gudgeon from a punt, it will not be necessary to rake the bottom of the river so long as you have bites. When they cease, the gravel must be raked up ; in doing which, the water is muddied, and worms and larvæ very likely are stirred up. The gudgeon by instinct swim towards the spot, and as the water clears, take the angler's bait dropped thereon. As soon as nibbling ceases again, the punt is to be removed up or down stream a little, and the rake must once more be used. The process must be repeated, not " every quarter of an hour," but every time your bait ceases to be attacked. The cessation is caused by your having caught all the gudgeons on the spot, or by there not having been any there at all. Continual raking and continual change of ground are requisite to secure successful gudgeonangling-a sort of pis-aller piscatorial pastime.-E.] 
than a gudgeon. He is an excellent fish, no fish that swims is of a pleasanter taste; and he is also excellent to enter a young angler, for he is a greedy biter; and they will usually lie abundance of them together, in one reserved place, where the water is deep and runs quietly; and an easy angler, if he has found where they lie, may catch forty or fifty, or sometimes twice as many, at a standing.

You must fish for him with a small red-worm; and if you bait the ground with earth, it is excellent.

There is also a Bleak, or fresh-water sprat, a fish that

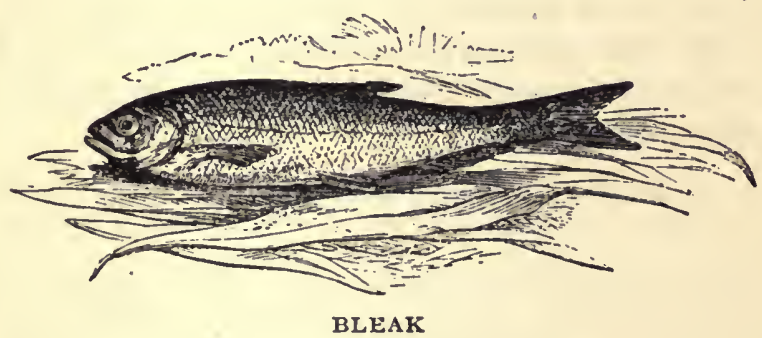

is ever in motion, and therefore called by some the riverswallow ; for just as you shall observe the swallow to be most evenings in summer ever in motion, making short and quick turns when he flies to catch flies in the air, by which he lives, so does the bleak at the top of the water. Ausonius would have him called bleak from his whitish colour : his back is of a pleasant sad or sea-water green, his belly white and shining as the mountain snow; and doubtless, though he have the fortune, which virtue has in poor people, to be neglected, yet the bleak ought to be much valued, though we want Allamot salt, and the skill tha. the Italians have to turn them into anchovies. This fish may be caught with a Paternoster line; * that is,

* A rosary, or string of beads, is used by the Roman Catholic devotees to assist them in numbering their pater-nosters, or prayers ; 
six or eight very small hooks tied along the line, one half a foot above the other: I have seen five caught thus at one time, and the bait has been gentles, than which none is better.

Or this fish may be caught with a fine small artificial fly, which is to be of a very sad brown colour, and very small, and the hook answerable. There is no better sport than whipping for bleaks in a boat, or on a bank, in the swift water, in a summer's evening, with a hazel top about five or six foot long, and a line twice the length of the rod. I have heard Sir Henry Wotton say, that there be many that in Italy will catch swallows so, or especially martins ; * this bird-angler standing on the top of a steeple to do it, and with a line twice as long as I have spoken of. And let me tell you, scholar, that both martins and bleaks be most excellent meat.

a line with many hooks at small distances from each other, though it little resembles a string of beads, is thence called a pater-noster line.-H.

[Every tenth bead on a rosary is larger than the others, so that when the devotee comes to it with his fingers, touching this large bead at the end of each tenth pater-noster, or Lord's prayer, he knows without the trouble of counting or looking, that he has repeated the prayers ten times. A rosary consists of several links of ten beads in each, between two larger beads. Rosaries are especially used by Roman Catholics when saying penitential prayers, enjoined by the confessor before he can grant absolution. For instance, so many pater-nosters and Ave Marias, or Hail Maries, for some particular sin confessed. Pater-noster lines are now generally used for perch-fishing. They seldom have more than three hooks, projecting, by means of being whipped on a pig's bristle, from the foot-line at least one foot apart. The hook nearest the bottom should be baited with a worm, the next with a live gudgeon or minnow, and that nearest the surface of the water with a gentle. Pike are frequently fished for with a very strong pater-noster, mounted with large hooks, each of which is to be baited with a live gudgeon, dace, roach, or small trout. This line is sunk by means of a bullet. $-\mathrm{E}$.]

* Sir J. Hawkins says, this practice was common in England in his time. It is not so now. However, it frequently happens that when a fly-fisher is walking along the banks, or through the fields, with his rod held perpendicularly, and his artiflcial flies-streaming bchind in the air, that they are taken by swallows, swifts, martins, and several of the fly-catching tribe of birds. If artificial flies deceive fish, why should they not deceive birds ?-E. 


\section{THE COMPLETE ANGLER}

And let me tell you, that I have known a heron that did constantly frequent one place, caught with a hook baited with a big minnow or small gudgeon. The line and the hook must be strong, and tied to some loose staff, so big as she cannot fly away with it, a line not exceeding two yards. 


\section{CHAPTER XVI}

IS OF NOTHING, OR THAT WHICH IS NOTHING WORTH

\section{[jourtb Đay]}

Pisc. My purpose was to give you some directions concerning Roach and Dace, and some other inferior fish, which make the angler excellent sport, for you know there is more pleasure in hunting the hare than in eating her; but I will forbear at this time to say any more, because you see yonder come our brother Peter and honest Coridon : but I will promise you, that as you and I fish, and walk to-morrow towards London, if I have now forgotten anything that I can then remember, I will not keep it from you.

Well met, gentlemen : this is lucky that we meet so just together at this very door. Come, hostess, where are you ? Is supper ready? Come, first give us drink, and be as quick as you can, for I believe we are all very hungry. Well, brother Peter, and Coridon, to you both ; come, drink, and then tell me what luck of fish: we two have caught but ten trouts, of which my scholar caught three; look, here's eight, and a brace we gave away: we have had a most pleasant day for fishing and talking, and are returned home both weary and hungry, and now meat and rest will be pleasant.

PET. And Coridon and I have had not an unpleasant day, and yet I have caught but five trouts : for indeed we went to a good honest ale-house, and there we played at shovel-board half the day; all the time that it rained we were there, and as merry as they that fished; and I am glad we are now with a dry house over our heads, for hark 
how it rains and blows. Come, hostess, give us more ale, and our supper with what haste you may: and when we have supped let us have your song, Piscator, and the catch that your scholar promised us; or else, Coridon will be dogged.

PISc. Nay, I will not be worse than my word; you shall not want my song, and I hope I shall be perfect in it.

VEN. And I hope the like for my catch, which I have ready too: and therefore let's go merrily to supper, and then have a gentle touch at singing and drinking; but the last with moderation.

Con. Come, now for your song; for we have fed heartily. Come, hostess, lay a few more sticks on the fire. And now, sing when you will.

PIsc. Well then, here's to you, Coridon; and now for my song.

$O$ the gallant fisher's life,

It is the best of any !

'Tis full of pleasure, void of strife,

And 'tis beloved by many:

Other joys

Are but toys ;

Only this

Lawful is ;

For our skill

Breeds no ill,

But content and pleasure.

In a morning up we rise,

Ere Aurora's peeping;

Drink a cup to wash our eyes ;

Leave the sluggard sleeping:

- Then we go

To and fro

With our knacks

At our backs,

To such streams

As the Thames,

If we have the leisure. 
When we plaase to walk abroad For our recreation,

In the fields is our abode,

Full of delectation:

Where in a brook,

With a hook,

Or a lake,

Fish we take ;

There we sit

For a bit,

Till we fish entangle.

We have gentles in a horn,

We have paste and worms too;

We can watch both night and morn,

Suffer rain and storms too.

None do here

Use to swear;

Oaths do fray

Fish away:

We sit still

And watch our quill ;

Fishers must not wrangle.

If the sun's excessive heat

Make our bodies swelter,

To an osier-hedge we get

For a friendly shelter ;

Where in a dike,

Perch or pike,

Roach or dace,

We do chase ;

Bleak or gudgeon,

Without grudging ;

We are still contented.

Or we sometimes pass an hour

Under a green willow,

That defends us from a shower-

Making earth our pillow :

Where we may

Think and pray, 
Before death

Stops our breath :

Other joys

Are but toys,

And to be lamented.-Jo. Crialkhill.

VeN. Well sung, master : this day's fortune and pleasure, and this night's company and song, do all make me more and more in love with angling. Gentlemen, my master left me alone for an hour this day; and I verily believe he retired himself from talking with me, that he might be so perfect in this song: was it not, master ?

Pisc. Yes indeed; for it is many years since I learned it, and having forgotten a part of it, I was forced to patch it up by the help of mine own invention, who am not excellent at poetry, as my part of the song may testify : but of that I will say no more, lest you should think I mean by discommending it to beg your commendations of it. And therefore, without replications, let us hear your catch, scholar, which I hope will be a good one; for you are both musical, and have a good fancy to boot.

Ven. Marry, and that you shall; and as freely as I would have my honest master tell me some more secrets of fish and fishing as we walk and fish towards London to-morrow. But, master, first let me tell you, that very hour which you were absent from me, I sat down under a willow-tree by the water-side, and considered what you had told me of the owner of that pleasant meadow in which you had then left me; that lie had a plentiful estate, and not a heart to tlink so ; that he had at this time many law-suits depending, and that they both damped his mirth and took up so much of his time and thoughts, that he himself had not leisure to take the sweet content that I, who pretended no title to them, took in his fields : for I could sit there quietly; and looking on the water, see some fishes sport themselves in the silver streams, others leaping at flies of several shapes and colours; $100-a^{*}$ 
looking on the hills, I could behold them spotted with woods and groves; looking down the meadows, could see, here a boy gathering lilies and lady-smocks, and there a girl cropping culverkeys and cowslips, all to make garlands suitable to this present month of May : these, and many other field-flowers, so perfumed the air, that I thought that very meadow like that field in Sicily of which Diodorus speaks, where the perfumes arising from the place make all dogs that hunt in it to fall off, and to lose their hottest scent. I say, as I thus sat, joying in my own happy condition, and pitying this poor rich man that owned this and many other pleasant groves and meadows about me, I did thankfully remember what my Saviour said, that the meek possess the earth; or rather, they enjoy what the others possess and enjoy not; for anglers and meek quiet-spirited men are free from those high, those restless thoughts, which corrode the sweets of life; and they, and they only, can say, as the poet has happily expressed it :

\section{Hail ! blest estate of lowliness ;}

Happy enjoyments of such minds

As, rich in self-contentedness,

Can, like the reeds in roughest winds,

By yielding make that blow but small,

At which proud oaks and cedars fall.

There came also into my mind, at that time, certain verses in praise of a mean estate and an humble mind; they were written by Phineas Fletcher, an excellent divine, and an excellent angler, and the author of excellent piscatory eclogues, in which you shall see the picture of this good man's mind, and I wish mine to be like it.*

* It would be great injustice to the memory of this person, whose name is now hardly known, to pass him by without notice. He was the son of Giles Fletcher, doctor of laws, and ambassador from Queen Elizabeth to the Duke of Muscovy; a fellow of King's College, Cambridge, and the author of a fine allegorical poem, entitled, "The Purple Island," printed at Cambridge, with other of his poems, in 4to, 1633; from whence the passage in the text, with a little variation, is taken.-H. 
No empty hopes, no courtly fears him fright ;

No begging wants his middle fortune bite :

But sweet content exiles both misery and spite.

His certain life, that never can deceive him,

Is full of thousand sweets and rich content;

The smooth-leaved beeches in the field receive him,

With coolest shade, till noontide's heat be spent.

His life is neither toss'd in boisterous seas

Or the vexatious world, or lost in slothful ease :

Pleased and full bless'd he lives, when he his God can please.

His bed, more safe than soft, yields quiet sleeps,

While by his side his faithful spouse hath place;

His little son into his bosom creeps,

The lively picture of his father's face ;

His humble house or poor state ne'er torment him-

Less he could like, if less his God had lent him ; And when he dies, green turfs do for a tomb content him.

Gentlemen, these were a part of the thoughts that then possessed me. And I there made a conversion of a piece of an old catch, and added more to it, fitting them to be sung by anglers. Come, master, you can sing well ; you must sing a part of it as it is in this paper.

Man's life is but vain ; for 'tis subject to pain, And sorrow, and short as a bubble ;

'Tis a hodge-podge of business, and money, and care, And care, and money, and trouble.

But we'll take no care when the weather proves fair ;

Nor will we vex now though it rain ;

We'll banish all sorrow, and sing till to-morrow,

And angle, and angle again.

Peter. Ay marry, Sir, this is music indeed; this has cheered my heart, and made me to remember six verses in praise of music, which I will speak to you instantly.

Music! miraculous rhetoric, that speakest sense Without a tongue, excclling eloquence; 
With what ease might thy errors be excused, Wert thou as truly loved as thou'rt abused !

But though dull souls neglect, and some reprove thee, I cannot hate thee, 'cause the angels love thee.

VEN. And the repetition of these last verses of music, has called to my memory what Mr. Ed. Waller,* a lover of the angle, says of love and music.

Whilst I listen to thy voice,

Chloris, I feel my heart decay:

That powerful noise

Calls my fleeting soul away :

O suppress that magic sound,

Which destroys without a wound !

Peace, Chloris, peace, or singing die,

That together you and I

To heaven may go;

For all we know

Of what the blessed do above

Is-that they sing, and that they love.

- As the author's concern for the honour of angling, induced him to enumerate such persons of note as were lovers of that recreation, the reader will allow me to add Mr. John Gay to the number. Any one who reads the first canto of his " Georgic," entitled Rural Sports, and observes how beautifully and accurately he treats the subject of fly-fishing, would conclude the author a proficient: but that it was his chief amusement, I have been assured, by an intimate friend of mine, who has frequently fished with him in the River Kennet, at Amesbury in Wilts, the seat of his grace the Duke of Queensberry.

The reader will excuse the following addition to this note, for the sake of a beautiful description of the material used in fly-making, which is quoted from the above-mentioned poem :-

"To frame the little animal, provide

All the gay hues that wait on female pride :

Let nature guide thee; sometimes golden wire

The shining bellies of the fly require;

The peacock's plumes thy tackle must not fail,

Nor the dear purchase of the sable's tail ;

Each gaudy bird some slender tribute brings,

And lends the growing insect proper wings;

Silks of all colours must their aid impart,

And every fur promote the fisher's art :

So the gay lady, with expensive care,

Borrows the pride of land, of sea, of air ;

Furs, pearls, and plumes, the glittering thing displays,

Dazzles our eyes, and easy hearts betrays." $-\mathrm{H}$. 
Pisc. Well remembered, brother Peter : these verses came seasonably, and we thank you heartily. Come, we will all join together, my host and all, and sing my scholar's catch over again, and then each man drink the other cup and to bed, and thank God we have a dry house over our heads.

PIsc. Well now, good night to everybody.

Peter. And so say I.

Ven. And so say I.

Cor. Good night to you all, and I thank you.

\section{[ffittb Day]}

PIsc. Good-morrow, brother Peter, and the like to you, honest Coridon : come, my hostess says there is seven shillings to pay: let us each man drink a pot for his morning's draught, and lay down his two shillings; that so my hostess may not have occasion to repent herself of being so diligent, and using us so kindly.

Peter. The motion is liked by everybody; and so, hostess, here's your money : we anglers are all beholding to you, it will not be long ere I'll see you again. And now, brother Piscator, I wish you and my brother your scholar a fair day and good fortune. Come, Coridon, this is our way. 


\section{CHAPTER XVII}

OF ROACH AND DACE, AND HOW TO FISH FOR THEM; AND OF CADIS

\section{[ffiftb פay]}

VEN. Good master, as we go now towards London, be still so courteous as to give me more instructions: for I have several boxes in my memory, in which I will keep them all very safe, there shall not one of them be lost.

PIsc. Well, scholar, that I will : and I will hide nothing from you that I can remember, and can think may help you forward towards a perfection in this art. And because we have so much time, and I have said so little of roach and dace, I will give you some directions concerning them.

Some say the Roach is so called from rutilus, which they say signifies red fins. He. is a fish of no great reputation for his dainty taste; and his spawn is accounted much better than any part of him. And you may take notice, that as the carp is accọunted the waterfox for his cunning; so the roach is accounted the watersheep for his simplicity or foolishness. It is noted, that the roach and dace recover strength, and grow in season a fortnight after spawning; the barbel and chub in a month : the trout in four months; and the salmon in the like time, if he gets into the sea, and after into fresh water.

Roaches be accounted much better in the river than in a pond, though ponds usually breed the biggest. But there is a kind of bastard small roach, that breeds 
in ponds, with a very forked tail, and of a very small size; which some say is bred by the bream and right roach; and some ponids are stored with these beyond belief; and knowing-men, that know their difference, call them ruds : they differ from the true roach as much as a herring from a pilchard. And these bastard breed of roach are now scattered in many rivers : but I think not in the Thames, which I believe afford the largest and fattest in this nation, especially below London Bridge.*

- I know not what roaches are caught below bridge, but above I am sure they are very large, for on the 15th of September, 1754, at Hampton, I caught one that was fourteen inches and an eighth from eye to fork, and in weight wanted but an ounce of two pounds. The scason for fishing for roach in the Thames begins about the latter end of August, and continues much longer than it is either pleasant or safe to fish. It requires some skill to hit the time of taking them exactly; for all the summer long they live on the weed, which they do not forsake for the deeps till it becomes putrid, and that is sooner or later, according as the season is wet or dry ; for you are to know, that much rain hastens the rotting of the weed: I say it requires some skill to hit the time ; for the fishermen who live in all the towns along the river, from Cliswick to Staines, are about this time nightly on the watch, as soon as the fish come out, to sweep them away with a drag-net; and our poor patient angler is left baiting the ground, and adjusting his tackle, to catch those very fish, which, perhaps, the night before had been carried to Billingsgate. The Thames, as well above as below London Bridge, was formerly much resorted to by the London anglers, and which is strange to think on, considering the unpleasantness of the station, they were used to fish near the starlings of the bridge. This will account for the many fishing-tackle shops that were formerly in Crooked Lane, which leads to the bridge. In the memory of a person, not long since living, a waterman that plied at Essex Stairs, his name Jolnn Reeves, got a comfortable living by attending anglers with his boat; his method was, to watch when the shoals of roach came down from the country, and when he had found them, to go round to his customers and give them notice. Sometimes they settled opposite the Temple, at others, at Blackfriars or Quecnhithe, but most frequently about the Chalk Hills, near London Briclge. His hire was two shillings a tide. A certain number of persons who were accustomed thus to employ him, raised a sum sufficient to buy him a waterman's coat and silver badge, the impress whereof was, himself with an angler in his boat, and he had annually a new coat to the time of his death. -H. Sir J. Hawkins adds as follows :- "Before I dismiss the subjeet of Thames fishing, I will let the reader know, that formerly the fishermen inhabiting the banks of the Thames, were used to inclose certain parts of the river with what they called stops, but which were in eflect, weirs, or kidels, by stakes driven into the bed 
Next, let me tell you, you shall fish for this roach in winter with paste or gentles; in April with warms or cadis ; in the very hot months with little white snails, or with flies under water, for he seldom takes them at the top, though the dace will. In many of the hot months, roaches may also be caught thus : take a Mayfly, or ant-fly, sink him with a little lead to the bottom, near to the piles or posts of a bridge, or near to any posts of a weir, I mean any deep place where roaches lie quietly, and then pull your fly up very leisurely, and usually a roach will follow your bait to the very

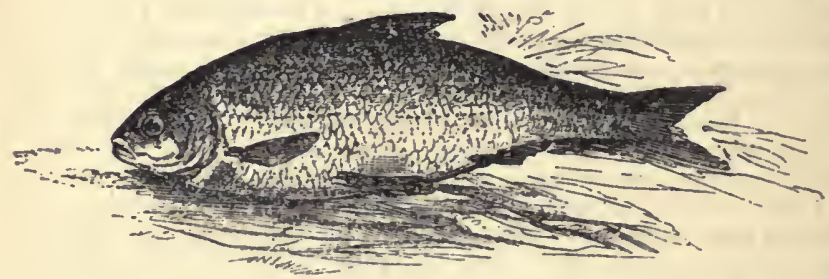

ROACH

top of the water, and gaze on it there, and run at it and take it, lest the fly should fly away from him.

I have seen this done at Windsor and Henley Bridge, and great store of roach taken, and sometimes a dace or chub ; and in August you may fish for them with a paste made only of the crumbs of bread, which should be of pure fine manchet; and that paste must be so tempered betwixt your hands, till it be both soft and tough too; a very little water, and time and labour, and clean hands,

thereof, and to these they tied wheels, creating thereby a current, which drove the fish into those traps. This practice, though it may sound oddly to say so, is against Magna Charta, and is expressly prohibited by the twenty-third chapter of that statute : In the year 1757, the Lord Mayor Dickenson sent the water-bailiff up the Thames in a barge well manned and furnished with proper implements, who destroyed a!l those inclosures on this slde of Staines, by pulling up the stakes and setting them adrift."-H. 
will make it a most excellent paste : but when you fish with it, you must have a small hook, a quick eye, and a nimble hand, or the bait is lost and the fish too; if onc may lose that which he never had. With this paste you may, as I said, take both the roach and Dace or Dare, for they be much of a kind, in matter of feeding, cunning, goodness, and usually in size. And therefore, take this general direction for some other baits which may concern you to take notice of. They will bite almost at any fly, but especially at ant-flies; concerning which, take this direction, for it is very good :

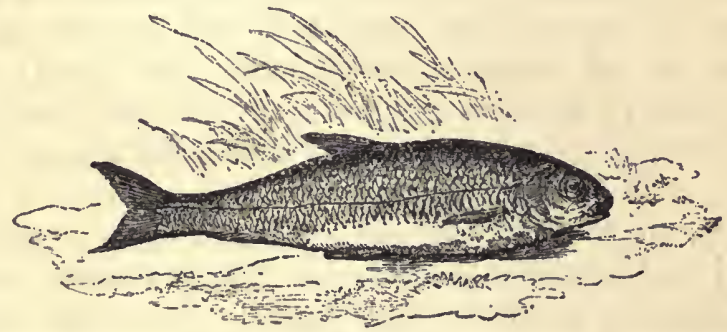

DACE

Take the blackish ant-fly out of the mole-hill or ant-hill, in which place you shall find them in the month of June, or if that be too early in the year, then doubtless you may find them in July, August, and most of September ; gather them alive with both their wings, and then put them into a glass that will hold a quart or a pottle; but first put into the glass a handful or more of the moist earth out of which you gather them, and as much of the roots of the grass of the said hillock, and then put in the flies gently, that they lose not their wings: lay a clod of earth over it, and then so many as are put into the glass without bruising, will live there a month or more, and be always in a readiness for you to fish with; but if you would have them keep longer, then get any 
great earthen pot, or barrel of three or four gallons, which is better, then wash your barrel with water and honey, and having put into it a quantity of earth and grass roots, then put in your flies, and cover it, and they will live a quarter of a year : these in any stream and clear water, are a deadly bait for roach or dace, or for a chub; and your rule is, to fish not less than a handful from the bottom.

I shall next tell you a winter bait for a roach, a dace, or chub, and it is choicely good. About All-hallontide and so till frost comes, when you set men ploughing up heath ground, or sandy-ground, or greenswards, then follow the plough, and you shall find a white worm as big as two maggots, and it hath a red head: you may observe in what ground most are, for there the crows will be very watchful and follow the plough very close : it is all soft, and full of whitish guts; a worm, that is, in Norfolk and some other counties, called a grub ; and is bred of the spawn or eggs of a beetle, which she leaves in holes that she digs in the ground under cow or horse-dung, and there rests all winter, and in March or April comes to be first a red, and then a black beetle. Gather a thousand or two of these, and put them with a peck or two of their own earth, into some tub or firkin, and cover and keep them so warm that the frost or cold air or winds kill them not: these you may keep all winter, and kill fish with them at any time; and if you put some of them into a little earth and honey, a day before you use them, you will find them an excellent bait for bream, carp, or indeed for almost any fish.

And after this manner you may also keep gentles all winter; which are a good bait then, and much the better for being lively and tough. Or you may breed and keep gentles thus: take a piece of beast's liver, and with a cross stick, hang it in some corner, over a pot or barrel half full of dry clay: and as the gentles 
grow big, they will fall into the barrel and scour themselves, and be always ready for use whensoever you incline to fish; and these gentles may be thus created till after Michaelmas. But if you desire to keep gentles to fish with all the year, then get a dead cat, or a kite, and let it be fly-blown; and when the gentles begin to be alive and to stir, then bury it and them in soft moist earth, but as free from frost as you can; and these you may dig up at any time when you intend to use them : these will last till March, and about that time turn to be flies.

But if you will be nice to foul your fingers, which good anglers seldom are, then take this bait: get a handful of well-made malt, and put into a dish of water; and then wash and rub it betwixt your hands till you make it clean, and as free from husks as you can; then put that water from it, and put a small quantity of fresh water to it, and set it in something that is fit for that purpose, over the fire, where it is not to boil apace, but leisurely and very softly, until it become somewhat soft, which you may try by feeling it betwixt your finger and thumb; and when it is soft, then put your water from it, and then take a sharp knife, and turning the sprout end of the corn upward, with the point of your knife take the back part of the husk off from it, and yet leaving a kind of inward husk on the corn, or else it is marr'd ; and then cut off that sprouted end, I mean a little of it, that the white may appear, and so pull off the husk on the cloven side, as I directed you, and then cutting off a very little of the other end, that so your hook may enter; and if your hook be small and good, you will find this to be a very choice bait either for winter or summer, you sometimes casting a little of it into the place where your float swims.

And to take the roach and dace, a good bait is the young brood of wasps or bees, if you dip their heads 
in blood; especially good for bream, if they be baked or hardened in their husks in an oven, after the bread is taken out of it, or hardened on a fire shovel; and so also is the thick blood of sheep, being half dried on a trencher, that so you may cut it into such pieces as may best fit the size of your hook, and a little salt keeps it from growing black, and makes it not the worse but better : this is taken to be a choice bait if rightly ordered.

There be several oils of a strong smell that I have been told of, and to be excellent to tempt fish to bite, of which I could say much; but I remember I once carried a small bottle from Sir George Hastings to Sir Henry Wotton, they were both chymical men, as a great present; it was sent and received, and used with great confidence; and yet upon enquiry, I found it did not answer the expectation of Sir Henry, which, with the help of this and other circumstances, makes me have little belief in such things as many men talk of : not but that I think fishes both smell and hear, as I have expressed in my former discourse; but there is a mysterious knack, which, though it be much easier than the philosopher's stone, yet it is not attainable by common capacities, or else lies locked up in the brain or breast of some chymical man, that, like the Rosicrucians, will not yet reveal it. But let me nevertheless tell you, that camphor,* put with moss into your worm-bag with your worms, makes them, if many anglers be not very much mistaken, a tempting bait, and the angler more fortunate. But I stepped by chance into this discourse of oils and fishes smelling; and though there might be more said, both of it and of baits for roach and dace and other float fish, yet I will forbear at this time, $\uparrow$ and tell you in the next place how you are to

* All scented baits are now justly repudiated. Perfuming a worm or any other bait will do harm and not good.-E.

+ Roach delight in gravelly or sandy bottoms; their haunts, especially as winter approaches, are clear, deep, and still waters ; 


\section{prepare your tackling; concerning which I will, for sport-sake, give you an old rhyme out of an old fish-book}

at other times they lie in and near weeds, and under the shade of boughs. They spawn about the latter end of May, when they are scabby and unwholesome, but they are again in order in about three weeks : the largest are taken after Michaelmas, and their prime season is in February or March. The baits for roach, not already mentioned, are cad-bait and oak-worms for the spring ; in May, ants' eggs, and paste made of the crumbs of a new roll, both white and tinged with red, which is done by putting vermilion into the water wherewith you moisten it; this paste will do for the winter also. The largest roach in this kingdom are taken in the Thames, where many have been caught of two pounds and a half weight; but roach of any size are hardly to be come at without a boat. The haunts of dace are gravelly, sandy, and clayey bottoms; deep holes that are shaded; water lily leaves, and under the foam caused by an eddy : in hot weather they are to be found on the shallows, and are then best taken with an artificial fly, grasshoppers, or gentles, as hereafter directed.

Dace spawn about the latter end of March, and are in season about three weeks after; they are not very good till about Michaelmas, and are best in February. Baits for dace, other than those mentioned by Walton, are the oak-worm, red-worm, brandling, gilt-tail, and indeed any worm bred on trees or bushes, that is not too big for his mouth : almost all kinds of flies and caterpillars. Though dace are often caught with a float as roach, yet they are not so properly floatfish; for they are to be taken with an artificial gnat, or ant-fly, or indeed, almost any other small fly in its season; but in the Thames, above Richmond, the largest are caught with a natural green or dun grasshopper, and sometimes with gentles; with both which you are to fish, as with an artificial fly; they are not to be come at till about September, when the weeds begin to rot; but when you have found where they lie, which in a warm day is generally on the shallows, 'tis incredible what havoc you may make : pinch off the first joint of the grasshopper's legs, put the point of the hook in at the head, and bring it out at the tail ; and in this way of fishing you will catch chub, especially if you throw under the boughs. It is true, there is less certainty of catching in this way than with a float or ground-bait : for which reason, I would recommend it only to those who live near the banks of that delightful river, between Windsor and Isleworth, who have or can command a boat for that purpose, and can take advantage of a still, warm, gloomy day ; and to such it will afford much more diversion than the ordinary inartificial method of fishing in the deeps for roach and dace. In fishing at bottom for roach and dace, use for groundbait, bread soaked about an hour in water, and an equal quantity of bran; knead them to a tougl consistence, and make them up into balls, with a small pebble in the middle: and throw these balls in where you fish; but be sure you throw them up the stream, for otherwise they will draw the fish beyond the reach of your line. Fish for roach within six, and for dace, within three inches of the bottom.-H. 
which will prove a part, and but a part, of what you are to provide.

My rod and my line, my float and my lead, My hook and my plummet, my whetstone and knife, My basket, my baits both living and dead,

My net, and my meat (for that is the chief) :

Then I must have thread, and hairs green and small,

With mine angling-purse-and so you have all.

But you must have all these tackling, and twice so many more, with which, if you mean to be a fisher, you must store yourself; and to that purpose I will go with you either to Mr. Margrave, who dwells amongst the booksellers in St. Paul's Churchyard, or to Mr. John Stubs, near to the Swan in Golden Lane; they be both honest men, and will fit an angler with what tackling he lacks.

VEN. Then, good master, let it be at $\longrightarrow$ for he is nearest to my dwelling; and I pray let us meet there the ninth of May next, about two of the clock, and I'll want nothing that a fisher should be furnished with.

Pisc. Well, and I'll not fail you (God willing) at the time and place appointed.

VEN. I thank you, good master, and I will not fail you: and, good master, tell me what baits more you remember, for it will not now be long ere we shall be at Tottenham High Cross, and when we come thither, I will make you some requital of your pains, by repeating as choice a copy of verses as any we have heard since we met together; and that is a proud word, for we have heard very good ones.

Pisc. Well, scholar, and I shall be then right glad to hear them; and I will, as we walk, tell you whatsoever comes in my mind, that I think may be worth your hearing. You may make another choice bait thus: 
take a handful or two of the best and biggest wheat you can get, boil it in a little milk, like as frumity is boiled; boil it so till it be soft, and then fry it very leisurely with honey, and a little beaten saffron dissolved in milk; and you will find this a choice bait, and good, I think, for any fish, especially for roach, dace, chub, or grayling : I know not but that it may be as good for a river carp, and especially if the ground be a little baited with it.

And you may also note, that the spawn of most fish is a very tempting bait, being a little hardened on a warm tile, and cut into fit pieces. Nay, mulberries, and those blackberries which grow upon briars, be good baits for chubs or carps: with these many have been taken in ponds, and in some rivers where such trees have grown near the water, and the fruits customarily dropped in it. And there be a hundred other baits, more than can be well named, which, by constant baiting the water, will become a tempting bait for any fish in it.

You are also to know, that there be divers kinds of cadis, or case worms, that are to be found in this nation, in several distinct counties, and in several little brooks that relate to bigger rivers; as namely, one cadis called a piper, whose husk or case is a piece of reed about an inch long, or longer, and as big about as the compass of a two-pence. These worms being kept three or four days in a woollen bag, with sand at the bottom of it, and the bag wet once a day, will in three or four days turn to be yellow; and these be a choice bait for the chub or chavender, or indeed for any great fish, for it is a large bait.

There is also a lesser cadis-worm, called a cock-spur, being in fashion like the spur of a cock, sharp at one end; and the case or house, in which this dwells, is made of small husks and gravel and slime, most curiously made of these, even so as to be wondered at, but not to be made by man, no more than a king-fisher's nest can, 
which is made of little fishes' bones, and having such a geometrical interweaving and connection, as the like is not to be done by the art of man : this kind of cadis is a choice bait for any float-fish ; it is much less than the piper-cadis, and to be so ordered; and these may be so preserved, ten, fifteen, or twenty days, or it may be longer.

There is also another cadis, called by some a strawworm, and by some a ruff-coat, whose house or case is made of little pieces of bents, and rushes, and straws, and water-weeds, and I know not what, which are so knit together with condensed slime, that they stick about her husk or case, not unlike the bristles of a hedgehog; these three cadises are commonly taken in the beginning of summer, and are good indeed to take any kind of fish, with float or otherwise. I might tell you of many more, which as these do early, so those have their time also of turning to be flies later in summer; but I might lose myself and tire you by such a discourse: I shall therefore but remember you, that to know these and their several kinds, and to what flies every particular cadis turns, and then how to use them, first as they be cadis, and after as they be flies, is an art, and an art that every one that professes to be an angler. has not leisure to search after, and, if he had, is not capable of learning.

I will tell you, scholar, several countries have several kinds of cadises, that indeed differ as much as dogs do; that is to say, as much as a very cur and a greyhound do. These be usually bred in the very little rills, or ditches, that run into bigger rivers : and, I think, a more proper bait for those very rivers than any other. I know not how, or of what, this cadis receives life, or what coloured fly it turns to ; but doubtless they are the death of many trouts; and this is one killing way:

Take one, or more if need be, of these large yellow cadis : pull off his head, and with it pull out his black 
gut ; put the body, as little bruised as is possible, on a very little hook, armed on with a red hair, which will shew like the cadis-head; and a very little thin lead, so put upon the shank of the hook that it may sink presently. Throw this bait, thus ordered, which will look very yellow, into any great still hole where a trout is, and he will presently venture his life for it, it is not to be doubted, if you be not espied; and that the bait first touch the water before the line. And this will do best in the deepest water.

Next let me tell you, I have been much pleased to walk quietly by a brook with a little stick in my hand, with which I might easily take these, and consider the curiosity of their composure : and if you shall ever like to do so, then note, that your stick must be a little hazel or willow, cleft, or have a nick at one end of it ; by which means you may with ease take many of them in that nick out of the water, before you have any occasion to use them. These, my honest scholar, are some observations told to you as they now come suddenly into my memory, of which you may make some use; but for the practical part, it is that that makes an angler: it is diligence, and observation, and practice, and an ambition to be the best in the art, that must do it.* I will tell you, scholar, I once heard one

* The author las now done describing the several kinds of fish, excepting the few little ones that follow, with the different methods of taking them, but has said little or nothing of float-fishing: it may not be amiss here to lay down some rules about it. Let the rod be light and stiff, and withal so smart in the spring, as to strike at the tip of the whalebone ; from fourteen to fifteen feet is a good lengtl. In places where you sometimes meet with barbel, as at Shepperton and Hampton, in Middlesex, the fittest line is one of six or seven hairs at top; and so diminishing for two yards, let the rest be strong Indian grass, to within about half a yard of the look, which may be whipped to a fine grass or silk-worm gut; and this line will kill a fish of six pounds weight. But for mere roach and dace fishing. accustom yourself to a single-hair line, with which an artist may kill a fish a pound and a lialf weight. For your float, in slow streams, a neat round goose-quill is proper ; but for deep or rapid rivers, or in an eddy, the cork, shaped like a pear, is indisputably the best; which should not, in general, exceed the size of a nutmeg; let not the quill, which you put through it, be more than half an inch above and below the cork; and this float, though some prefer a 
say, "I envy not him that eats better meat than I do, nor him that is richer, or that wears better clothes than I do; I envy nobody but him, and him only, that catches more fish than I do." And such a man is like to prove an angler ; and this noble emulation I wish to you and all young anglers.

swan's quill, has great advantage over a bare quill ; for the quill being defended from the water by the cork, does not soften, and the cork enables you to lead your line so heavily, as that the hook sinks almost as soon as you put it into the water; whereas, when you lead but lightly, it does not get to the bottom till it is near the end of your swim. In leading your lines, be careful to balance them so nicely, that a very small touch will sink them; some use for this purpose lead shaped like a barley-corn, but there is nothing better to lead with than shot, which you must have ready cleft always with you ; remembering that when you fish fine, it is better to have on your line a great number of small than a few large shot. Whip the end of the quill round the plug with fine silk, well waxed; this will keep the water out of your float, and preserve it greatly. In fishing with a float, your line must be about a foot shorter than your rod ; for if it is longer, you cannot so well command your hook when you come to disengage your fish.- $\mathbf{H}$. 


\section{CHAPTER XVIII}

OF THE MINNOW OR PENK, OF THE LOACH, AND OF THE BULL-HEAD OR MILLER'S-THUMB

\section{[Jjiftb Dav]}

PISc. There be also three or four other little fish that I had almost forgot, that are all without scales, and may for excellency of meat be compared to any fish of greatest value and largest size. They be usually full of eggs or spawn all the months of summer; for they breed often, as it is observed mice, and many of the smaller four-footed creatures of the earth do ; and as those, so these, come quickly to their full growth and perfection. And it is needful that they breed both often and numerously, for they be, besides other accidents of ruin, both a prey and baits for other fish. And first, I shall tell you of the Minnow or Penk.

The minnow hath, when he is in perfect season, and not sick, which is only presently after spawning, a kind of dappled or waved colour, like to a panther, on his sides, inclining to a greenish and sky-colour, his belly being milk white, and his back almost black or blackish. He is a sharp biter at a small worm, and in hot weather makes excellent sport for young anglers, or boys, or women that love that recreation, and in the spring they make of them excellent minnow-tansies; for being washed well in salt, and their heads and tails cut off, and their guts taken out, and not washed after, they prove excellent for that use ; that is, being fried with yolks of eggs, the flowers of cow- 
slips, and of primroses, and a little tansy ; thus used, they make a dainty dish of meat.

The Loach is, as I told you, a most dainty fish; he breeds and feeds in little and clear swift brooks or rills, and lives there upon the gravel, and in the sharpest streams: he grows not to be above a finger long, and no thicker than is suitable to that length. This loach is not unlike the shape of the eel; he has a beard or wattles like a barbel. He has two fins at his sides, four at his belly, and one at his tail ; he is dappled with many

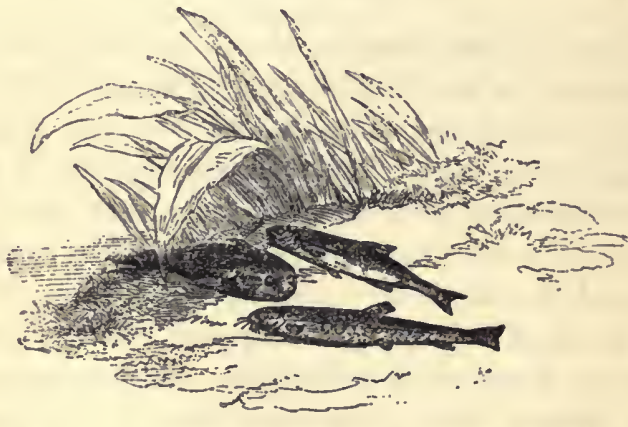

MINNOW, LOACH, AND MILLER'S-THUMB

black or brown spots, his mouth is barbel-like under his nose.

This fish is usually full of eggs or spawn; and is by Gesner, and other learned physicians, commended for great nourishment, and to be very grateful both to the palate and stomach of sick persons : he is to be fished for with a very small worm at the bottom, for he very seldom or never rises above the gravel, on which I told you he usually gets his living.

The Miller's-Thumb, or Bull-head, is a fish of no pleasing shape.

He is by Gesner compared to the sea-toad-fish, for his 
similitude and shape. It has a head big and flat, much greater than suitable to his body; a mouth very wide, and usually gaping; he is without teeth, but his lips are very rough, much like to a file. He hath two fins near to his gills, which be roundish or crested ; two fins also under the belly; two on the back; one below the vent; and the fin of his tail is round. Nature hath painted the body of this fish with whitish, blackish, and brownish spots.* They be usually full of eggs or spawn all the summer, I mean the females; and those eggs swell their vents almost into the form of a dug. They begin to spawn about April, and, as I told you, spawn several months in the summer. And in the winter, the minnow, and loach, and bull-head dwell in the mud, as the eel doth; or we know not where, no more than we know where the cuckoo and swallow, and other half-year birds, which first appear to us in April, spend their six cold, winter, melancholy months. This fish does usually dwell, and hide himself, in holes, or amongst stones in clear water ; and in very hot days will lie a long time very still, and sun himself, and will be easy to be seen upon any flat stone, or any gravel ; at which time he will suffer an angler to put a hook, baited with a small worm, very near unto his mouth; and he never refuses to bite, nor indeed to be caught with the

* Since Walton wrote, there has been brought into England, from Germany, a species of small fish, resembling carp in shape and colour, called "crusians," with which many ponds are now plentifully stocked. There have also been brought hither from China those beautiful creatures, gold and silver fish : the first are of an orange colour, with very shining scales, and finely variegated with black and dark brown; the silver fish are of the colour of silver tissue, with searlet fins, with which colour they are curiously marked in several parts of the body. These fish are usually kept in ponds, basins, and small reservoirs of water, to which they are a delightful ornament. And it is now a very common practice to keep them in a large glass vessel like a punch-bowl, with fine gravel strewed at the bottom ; frequently changing the water, and feeding them with bread and gentles. Those who can take more pleasure in angling for than in beholding them (which I confess I could never do), may catch them witl gentles; but though costly, they are but coarse food. $-\mathrm{H}$. 
worst of anglers. Matthiolus* commends him much more for his taste and nourishment, than for his shape or beauty.

There is also a fish called a Sticklebag, a fish without scales, but hath his body fenced with several prickles. I know not where he dwells in winter, nor what he is good for in summer, but only to make sport for boys and women-anglers, and to feed other fish that be fish of prey, as trout in particular, who will bite at him as at a penk, and better, if your hook be rightly baited with him; for he may be so baited as, his tail turning like the sail of a windmill, will make him turn more quick than any penk or minnow can. For note, that the nimble turning of that, or the minnow, is the perfection of minnow fishing. To which end, if you put your hook into his mouth, and out at his tail, and then, having first tied him with white thread a little above his tail, and placed him after such a manner on your hook as he is like to turn, then sew up his mouth to your line, and he is like to turn quick, and tempt any trout; but if he do not turn quick, then turn his tail a little more or less towards the inner part, or towards the side of the hook, or put the minnow, or sticklebag, a little more crooked or more strait on your hook, until it will turn both true and fast, and then doubt not but to tempt any great trout that lies in a swift stream. And the loach that I told you of will do the like : no bait is more tempting, provided the loach be not too big.

And now, scholar, with the help of this fine morning, and your patient attention, I have said all that my present memory will afford me, concerning most of the several fish that are usually fished for in fresh waters.

VEN. But, master, you have, by your former civility, made me hope that you will make good your promise, and

* Petrus Andreas Matthiolus, of Sienna, an eminent physician of the sixteenth century, famous for his commentaries on some of the writings of Dioscorides. 
say something of the several rivers that be of most note in this nation; and also of fish-ponds, and the ordering of them; and do it, I pray, good master, for I love any discourse of rivers, and fish and fishing ; the time spent in such discourse passes away very pleasantly. 


\section{CHAPTER XIX}

OF SEVERAL RIVERS, AND SOME OBSERVATIONS OF FISH

\section{[Jiftb Day]}

Pisc. Well, scholar, since the ways and weather do both favour us, and that we yet see not Tottenham Cross, you shall see my willingness to satisfy your desire. And first, for the rivers of this nation, there be, as you may note out of Doctor Heylin's Geography, and others, in number three hundred and twenty-five, but those of chiefest note he reckons and describes as followeth:

1. The chief is Thamesis, compounded of two rivers, Thame and Isis, whereof the former, rising somewhat beyond Thame in Buckinghamshire, and the latter near Cirencester in Gloucestershire, meet together about Dorchester in Oxfordshire; the issue of which happy conjunction is the Thamesis, or Thames; hence it flietl between Berks, Buckinghamshire, Middlesex, Surrey, Kent, and Essex : and so weddeth himself to the Kentish Medway, in the very jaws of the ocean. This glorious river feeleth the violence and benefit of the sea more than any river in Europe, ebbing and flowing twice a day, more than sixty miles; about whose banks are so many fair towns and princely palaces that a German * poet thus truly spake :

* Who this German poet was I cannot find ; but the verses, in the original Latin, are in Heylin's Cosmography, p. 240, and are as follow :-

Tot campos, sylvas, tot regia tecta, tot hortos, Artinci excultos dextra, tot vidimus arces ;

Ut nunc Ausonio, Thamesis, cum Tibride certet.-IJ. 
Tot campos, etc.

We saw so many woods and princely bowers, Sweet fields, brave palaces, and stately towers, So many gardens dress'd with curious care, That Thames with royal Tiber may compare.

2. The second river of note is Sabrina, or Severn; it hath its beginning in Plynlimmon Hill, in Montgomeryshire, and his end seven miles from Bristol, washing, in the mean space, the walls of Shrewsbury, Worcester, and Gloucester, and divers other places and palaces of note.

3. Trent, so called from thirty kind of fishes* that are found in it, or for that it receiveth thirty lesser rivers ; who, having its fountain in Staffordshire, and gliding through the counties of Nottingham, Lincoln, Leicester, and York, augmenteth the turbulent current of Humber, the most violent stream of all the isle. This Humber is not, to say truth, a distinct river, having a spring-head of his own, but it is rather the mouth or æstuarium of divers rivers here confluent, and meeting together, namely, your Derwent, and especially of Ouse and Trent; and (as the Danow, having received into its channel the River Dravus, Savus, Tibiscus, and divers others) changeth his name into this of Humberabus, as the old geographers call it.

4. Medway, a Kentish river, famous for harbouring the royal navy.

5. Tweed, the north-east bound of England; on whose northern banks is seated the strong and impregnable town of Berwick.

6. Tyne, famous for Newcastle, and her inexhaustible coal-pits. These, and the rest of principal note, are thus comprennded in one of Mr. Drayton's sonnets.

* Some say because it has thirty (trente) tributaries. It is more likely that the Trent had that number of streams, great and small, running into it, than that it ever produced thirty different varieties of fish.-E. 
Our floods' queen, Thames, for ships and swans is crown'd ; And stately Severn for her shore is praised; The crystal 'Trent, for fords and fish renown'd ;

And Avon's fame to Albion's cliffs is raised.

Carlegion Chester vaunts her holy Dee ;

York many wonders of her Ouse can tell ;

The Peak, her Dove, whose banks so fertile be ;

And Kent will say, her Medway doth excel.

Cotswold commends her Isis to the Thame;

Our northern borders boast of Tweed's fair flood;

Our western parts extol their Willy's fame ;

And the old Lea brags of the Danish blood.*

These observations are out of learned Dr. Heylin, and my old deceased friend, Michael Drayton; and because you say you love such discourses as these, of rivers and fish and fishing, I love you the better, and love the more to impart them to you. Nevertheless, scholar, if I should begin but to name the several sorts of strange fish that are usually taken in many of those rivers that run into the sea, I might beget wonder in you, or unbelief, or both; and yet $I$ will venture to tell you a real truth concerning one lately dissected by Dr. Wharton, a man of great learning and experience, and of equal freedom to communicate it; one that loves me and my art; one to whom I have been beholden for many of the choicest observations that I have imparted to you. This good man, that dares do anything rather than tell an untruth, did, I say, tell me he had lately dissected one strange fish, and he thus described it to me :

"The fish was almost a yard broad, and twice that length; his mouth wide enough to receive, or take into it, the head of a man ; his stomach, seven or eight

* The Danes, in the time of King Alfred, entered the Lea; and ascending it in their small ships to a distance of twenty miles, built a castle upon its banks near Hertford or Ware : hence the allusion, "Danish blood."-E. 
inches broad. He is of a slow motion, and usually lies or lurks close in the mud, and has a movable string on his head, about a span or near unto a quarter of a yard long, by the moving of which, with his natural bait, when he lies close and unseen in the mud, he draws other fish so close to him that he can suck them into his mouth, and so devours and digests them."

And, scholar, do not wonder at this, for besides the credit of the relator, you are to note, many of these, and fishes that are of the like and more unusual shapes, are very often taken on the mouths of our sea-rivers, and on the sea-shore. And this will be no wonder to any that have travelled Egypt; where 'tis known, the famous River Nilus does not only breed fishes that yet want names, but by the overflowing of that river, and the help of the sun's heat on the fat slime which that river leaves on the banks when it falls back into its natural channel, such strange fish and beasts are also bred, that no man can give a name to, as Grotius, in his Sophom, and others, have observed?

But whither am I strayed in this discourse? I will end it by telling you, that at the mouth of some of these rivers of ours herrings are so plentiful, as namely, near to Yarmouth in Norfolk, and in the west country pilchers so very plentiful, as you will wonder to read what our learned Camden relates of them in his Britannia, p. 178, 186.

Well, scholar, I will stop here, and tell you what by reading and conference I have observed concerning fish-ponds. 


\section{CHAPTER XX}

OF FISH-PONDS, AND HOW TO ORDER THEM

\section{[Jfiftb Dav]}

Pisc. Doctor Lebault, the learned Frenchman, in his large discourse of Maison Rustique,* gives this direction for making of fish-ponds; I shall refer you to him to read it at large, but I think I shall contract it, and yet make it as useful.

He adviseth, that when you have drained the ground, and made the earth firm where the head of the pond must be, that you must then, in that place, drive in two or three rows of oak or elm piles, which should be scorched in the fire, or half-burnt, before they be driven into the earth ; for being thus used, it preserves them much longer from rotting: and having done so, lay faggots or bavins of smaller wood betwixt them, and then earth betwixt and above them, and then having first very well rammed them and the earth, use another pile in like manner as the first were : and note, that the second pile is to be of or about the height that you intend to make your sluice or flood-gate, or the vent that you intend shall convey the overflowings of your pond in any flood that shall endanger the breaking of the ponddam.

Then he advises, that you plant willows or owlers about it, or both, and then cast in bavins in some places, not

* This book, translated into English by Richard Surflet, and corrected by Gervase Markham, is extant, under the title of The Country Farm. London, 1616, folio. 
far from the side, and in the most sandy places, for fish both to spawn upon, and to defend them and the young fry from the many fish, and also from vermin that lie at watch to destroy them, especially the spawn of the carp and tench, when 'tis left to the mercy of ducks or vermin.

$\mathrm{He}$ and Dubravius, and all others advise, that you make choice of such a place for your pond, that it may be refreshed with a little rill, or with rain-water, running or falling into it; by which, fish are more inclined both to breed, and are also refreshed and fed the better, and do prove to be of a much sweeter and more pleasant taste.

To which end it is observed, that such pools as be large, and have most gravel and shallows where fish may sport themselves, do afford fish of the purest taste. And note, that in all pools, it is bést for fish to have some retiring place ; as namely, hollow banks, or shelves, or roots of trees, to keep them into danger; and, when they think fit, from the extreme heat of the summer; as also, from the extremity of cold in winter. And note, that if many trees be growing about your pond, the leaves thereof, falling into the water, make it nauseous to the fish, and the fish to be so to the eater of it.

'Tis noted that the tench and eel love mud: and the carp loves gravelly ground, and in the hot months to feed on grass. You are to cleanse your pond, if you intend either to profit or pleasure, once every three or four yearfy (especially some ponds), and then let it lie dry six or twelve months, both to kill the water-weeds, as water-lilies, candocks, reate, and bulrushes, that breed there; and also that as these die for want of water, so grass may grow in the pond's bottom, which carps will eat greedily in all the hot months, if the pond be clean. The letting your pond dry, and sowing oats in the bottom, is also good, for the fish feed the faster: 
and being sometimes let dry, you may observe what kind of fish either increases or thrives best in that water ; for they differ much, both in their breeding and feeding.

Lebault also advises, that if your ponds be not very large and roomy, that you often feed your fish, by throwing into them chippings of bread, curds, grains, or the entrails of chickens or of any fowl or beast that you kill to feed yourselves; for these afford fish a great relief. He says, that frogs and ducks do much harm, and devour both the spawn and the young fry of all fish, especially of the carp; and I have, besides experience, many testimonies of it. But Lebault allows water-frogs to be good meat, especially in some months, if they be fat: but you are to note, that he is a Frenchman; and we English will hardly believe him, though we know frogs are usually eaten in his country: however, he advises to destroy them and king-fishers out of your ponds. And he advises not to suffer much shooting at wild fowl; for that, he says, affrightens and harms and destroys the fish.

Note, that carps and tench thrive and breed best when no other fish is put with them into the same pond ; for all other fish devour their spawn, or at least the greatest part of it. And note, that clods of grass thrown into any pond, feed any carps in summer; and that garden-earth and parsley thrown into a pond recovers and refreshes the sick fish. And note, that when you store your pond, you are to put into it two or three melters for one spawner, if you put them into a breeding pond; but if into a nurse-pond or feeding-pond, in which they will not breed, then no care is to be taken, whether there be most male or female carps.

It is observed, that the best ponds to breed carps are those that be stony or sandy, and are warm and free from wind, and that are not deep, but have willowtrees and grass on their sides, over which the water 
sometimes flows: and note, that carps do more usually breed in marle-pits, or pits that have clean clay-bottoms, or in new ponds, or ponds that lie dry a winter season, than in old ponds that be full of mud and weeds.

Well, scholar, I have told you the substance of all that either observation, or discourse, or a diligent survey of Dubravius and Lebault hath told me: not that they in their long discourses have not said more; but the most of the rest are so common observations, as if a man should tell a good arithmetician, that twice two is four. I will therefore put an end to this discourse, and we will here sit down and rest us.*

* It is observable that the author has said very little of pondfishing, which is in truth a dull recreation; and to which I have heard it objected, that fish in ponds are already caught. Nevertheless I find, that in the canal at St. James's Park, which, thougl a large one, is yet a pond, it was, in the reign of Charles II., the practice of ladies to angle.

" Beneath, a shoal of silver fishes glides, And plays about the gilded barges' sides ; The ladies, angling in the crystal lake, Feast on the waters with the prey they take : At once victorious with their lines and eyes, They make the fishes and the men their prize."

-Waller, "Poem on St. James's Park," lately improved by His Majesty.-H. 


\section{CHAPTER XXI}

DIRECTIONS FOR MAKING OF A LINE, AND FOR THE COLOURING OF BOTH ROD AND LINE

\section{[j]ftb (last) Day]}

Pisc. Well, scholar, I have held you too long about these cadis, and smaller fish, and rivers, and fish-ponds; and my spirits are almost spent, and so I doubt is your patience: but being, we are now almost at Tottenham, where I first met you, and where we are to part, I will lose no time, but give you a little direction how to make and order your lines, and to colour the hair of which you make your lines, for that is very needful to be known of an angler; and also how to paint your rod, especially your top ; for a right grown top is a choice commodity, and should be preserved from the water soaking into it, which makes it in wet weather to be heavy and fish ill-favouredly, and not true; and also it rots quickly for want of painting : and I think a good top is worth preserving, or I had not taken care to keep a top above twenty years.

But first for your line. First, note, that you are to take care that your hair be round and clear, and free from galls or scabs or frets, for a well-chosen, even, clear, round hair, of a kind of glass-colour, will prove as strong as three uneven scabby hairs, that are ill-chosen, and full of galls or unevenness. You shall seldom find a black hair but it is round, but many white are flat and uneven; therefore, if you get a lock of right round, clear, glass-colour hair, make much of it.

And for making your line, observe this rule; first 
let your hair be clean washed ere you go about to twist it ; and then choose not only the clearest hair for it, but hairs that be of an-equal bigness, for such do usually stretch altogether, and break altogether, which hairs of an unequal bigness never do, but break singly, and so deceive the angler that trusts to them.

When you have twisted your links, lay them in water for a quarter of an hour at least, and then twist them over again, before you tie them into a line: for those that do not so, shall usually find their line to have a hair or two shrink, and be shorter than the rest at the first fishing with it, which is so much of the strength of the line lost for want of first watering it and then re-twisting it; and this is most visible in a seven-hair line, one of those which hath always a black hair in the middle.

And for dyeing of your hairs, do it thus : take a pint of strong ale, half a pound of soot, and a little quantity of the juice of walnut-tree leaves, and an equal quantity of alum; put these together in a pot, pan, or pipkin, and boil them half an hour; and having so done, let it cool ; and being cold, put your hair into it, and there let it lie; it will turn your hair to be a kind of water or glass-colour, or greenish; and the longer you let it lie, the deeper it will be. You might be taught to make many other colours, but it is to little purpose; for doubtless the water-colour or glass-coloured hair is the most choice and most useful for an angler, but let it not be too green.

But if you desire to colour hair greener, then do it thus : take a quart of small ale, half a pound of alum; then put these into a pan or pipkin, and your hair into it with them; then put it upon a fire, and let it boil softly for half an hour; and then take out your hair, and let it dry ; and having so done, then take a pottle of water, and put into it two handfuls of marigolds, and 
cover it with a tile or what you think fit, and set it again on the fire, where it is to boil again softly for half an hour, about which time the scum will turn yellow; then put into it half a pound of copperas beaten small, and with it the hair that you intend to colour; then let the hair be boiled softly till half the liquor be wasted, and then let it cool three or four hours with your hair in it; and you are to observe, that the more copperas you put into it, the greener it will be ; but doubtless, the pale green is best: but if you desire yellow hair, which is only good when the weeds rot, then put in the more marigolds, and abate most of the copperas, or leave it quitc out, and take a little verdigrease instead of it.

This for colouring your hair. And as for painting your rod, which must be in oil, you must first make a size with glue and water, boiled together until the glue be dissolved, and the size of a lye-colour; then strike your size upon the wood with a bristle, or a brush, or pencil, whilst it is hot ; that being quite dry, take whitelead, and a little red-lead, and a little coal-black, so much as altogether will make an ash-colour; grind these all together with linseed-oil; let it be thick, and lay it thin upon the wood with a brush or pencil; this do for the ground of any colour to lie upon wood.

For a green, take pink and verdigrease, and grind them together in linseed-oil, as thin as you can well grind it; then lay it smoothly on with your brush, and drive it thin; once doing, for the most part will serve, if you lay it well ; and if twice, be sure your first colour be thoroughly dry before you lay on a second.

Well, scholar, having now taught you to paint your rod, and we having still a mile to Tottenham High Cross, I will, as we walk towards it, in the cool shade of this sweet honeysuckle hedge, mention to you some of the thoughts and joys that have possest my soul since we two met together. And these thoughts shall be told you, that you 
also may join with me in thankfulness, to the Giver of every good and perfect gift, for our happiness. And that our present happiness may appear to be the greater, and we the more thankful for it, I will beg you to consider with me, how many do, even at this very time, lie under the torment of the stone, the gout, and toothache; and this we are free from. And every misery that I miss is a new mercy, and therefore let us be thankful. There have been, since we met, others that have met disasters of broken limbs ; some have been blasted, others thunderstrucken; and we have been freed from these, and all those many other miseries that threaten human nature; let us therefore rejoice, and be thankful. Nay, which is a far greater mercy, we are free from the unsupportable burthen of an accusing tormenting conscience, a misery that none can bear; and therefore let us praise Him for His preventing grace, and say, every misery that I miss is a new mercy : nay, let me tell you, there be many that have forty times our estates, that would give the greatest part of it to be healthful and cheerful like us ; who, with the expense of a little money, have eat and drank, and laught, and angled, and sung, and slept securely; and rose next day, and cast away care, and sung, and laught, and angled again; which are blessings rich men cannot purchase with all their money. Let me tell you, scholar, I have a rich neighbour, that is always so busy that he has no leisure to laugh; the whole business of his life is to get money, and more money, that he may still get more and more money; he is still drudging on, and says, that Solomon says, "The diligent hand maketh rich": and it is true indeed; but, he considers not that it is not in the power of riches to make a man happy : for it was wisely said, by a man of great observation, "That there be as many miseries beyond riches, as on this side them ": and yet God deliver us from pinching poverty ; and grant, that having a competency, we may be content, and thank- 
ful. Let not us repine, or so much as think the gifts of God unequally dealt, if we see another abound with riches, when, as God knows, the cares that are the keys that keep those riches hang often so heavily at the rich man's girdle, that they clog him with weary days and restless nights, even when others sleep quietly. We see but the outside of the rich man's happiness: few consider him to be like the silkworm, that, when she seems to play, is, at the very same time, spinning her own bowels, and consuming herself ; and this many rich men do, loading themselves with corroding cares, to keep what they have, probably, unconscionably got. Let us, therefore, be thankful for health and a competence; and above all, for a quiet conscience.

Let me tell you, scholar, that Diogenes walked on a day, with his friend, to see a country fair; where he saw ribbons and looking-glasses, and nut-crackers and fiddles and hobby-horses and many other gimcracks; and, having observed them, and all the other finnimbruns that make a complete country fair, he said to his friend, "Lord, how many things are there in this world of which Diogenes hath no need!" And truly it is so, or might be so, with very many who vex and toil themselves to get what they have no need of. Can any man charge God that He hath not given him enough to make his life happy? No, doubtless; for nature is content with a little. And yet you shall hardly meet with a man that complains not of some want; though he, indeed, wants nothing but his will; it may be, nothing but his will of his poor neighbour, for not worshipping or not flattering him : and thus, when we might be happy and quiet, we create trouble to ourselves. I have heard of a man that was angry with himself because he was no taller; and of a woman that broke her looking-glass because it would not show her face to be as young and handsome as her next neighbour's was. And I knew another to whom God had given 
health and plenty, but a wife that nature had made peevish, and her husband's riches had made purse-proud; and must, because she was rich, and for no other virtue, sit in the highest pew in the church; which being denied her, she engaged her husband into a contention for it, and at last into a law-suit with a dogged neighbour who was as rich as he, and had a wife as peevish and purseproud as the other: and this law-suit begot higher oppositions, and actionable words, and more vexations and law-suits; for you must remember that both were rich, and must therefore have their will. Well, this wilful, purse-proud law-suit, lasted during the life of the first husband; after which his wife vext and chid, and chid and vext till she also chid and vext herself into her grave : and so the wealth of these poor rich people was curst into a punishment, because they wanted meek and thankful hearts ; for those only can make us happy. I knew a man that had health and riches, and several houses, all beautiful, and ready furnished, and would often trouble himself and family to be removing from one house to another ; and being asked by a friend, why he removed so often fom one house to another, replied, "It was to find content in some one of them." But his friend knowing his temper, told him, If he would find content in any of his houses, he must leave himself behind him; for content will never dwell but in a meek and quiet soul. And this may appear, if we read and consider what our Saviour says in St. Matthew's Gospel ; for He there says,"Blessed be the merciful, for they shall obtain mercy.Blessed be the pure in heart, for they shall see God.Blessed be the poor in spirit, for theirs is the kingdom of heaven." And, "Blessed be the meek, for they shall possess the earth." Not that the meek shall not also obtain mercy, and see God, and be comforted, and at last come to the kingdom of heaven; but in the meantime he, and he only, possesses the earth as he goes towards 
that kingdom of heaven, by being humble and cheerful, and content with what his good God has allotted him. He has no turbulent, repining, vexatious thoughts that he deserves better; nor is vext when he sees others possest of more honour or more riches than his wise God has allotted for his share; but he possesses what he has with a meek and contented quietness, such a quietness as makes his very dreams pleasing, both to God and himself.

My honest scholar, all this is told to incline you to thankfulness; and to incline you the more, let me tell you, that though the prophet David was guilty of murder and adultery, and many other of the most deadly sins, yet he was said to be a man after God's own heart, because he abounded more with thankfulness than any other that is mentioned in Holy Scripture, as may appear in his book of Psalms; where there is such a commixture of his confessing of his sins and unworthiness, and such thankfulness for God's pardon and mercies, as did make him to be accounted, even by God Himself, to be a man after His own heart: and let us, in that, labour to be as like him as we can; let not the blessings we receive daily from God make us not to value or not praise Him because they be common ; let us not forget to praise Him for the innocent mirth and pleasure we have met with since we met together. What would a blind man give to see the pleasant rivers and meadows and flowers and fountains that we have met with since we met together? I have been told, that if a man that was born blind could obtain to have his sight for but only one hour during his whole life, and should, at the first opening of his eyes, fix his sight upon the sun when it was in its full glory, either at the rising or setting of it, he would be so transported and amazed, and so admire the glory of it, that he would not willingly turn his eyes from that first ravishing object, to behold all the other various beauties this world could present to him. And this, and many other like blessings, 
we enjoy daily. And for most of them, because they be so common, most men forget to pay their praises : but let not us, because it is a sacrifice so pleasing to Him that made that sun and us, and still protects us, and gives us flowers and showers, and stomachs and meat, and content and leisure to go a-fishing.

Well, scholar, I have almost tired myself, and, I fear, more than almost tired you; but I now see Tottenham High Cross, and our short walk thither shall put a period to my too long discourse, in which my meaning was and is, to plant that in your mind, with which I labour to possess my own soul : that is, a meek and thankful heart. And to that end, I have shewed you that riches, without them, do not make any man happy. But let me tell you, that riches, with them, remove many fears and cares; and therefore my advice is, that you endeavour to be honestly rich, or contentedly poor: but be sure that your riches be justly got, or you spoil all. For it is well said by Caussin, * "he that loses his conscience, has nothing left that is worth keeping." Therefore be sure you look to that. And, in the next place, look to your health : and if you have it, praise God, and value it next to a good conscience; for health is the second blessing that we mortals are capable of; a blessing that money cannot buy, and therefore value it, and be thankful for it. As for money, which may be said to be the third blessing, neglect it not : but note, that there is no necessity of being rich : for I told you there be as many miseries beyond riches, as on this side them: and, if you have a competence, enjoy it with a meek, cheerful, thankful heart.

* Nicholas Caussin, a native of Troyes in Champagne, wrote a book called, The Holy Court; of which there is an English translation in folio. He was esteemed a person of great probity, and of such a spirit, that he attempted to displace Cardinal Richelieu; but that minister proved too hard for him, and got him banished. The sentiment above quoted from him, is worthy of Marcus Antoninus, or, if that be not enough to say, of Dr. Jereny Taylor himself. $-\mathrm{H}$. 
I will tell you, scholar, I have heard a grave divine * say, that God has two dwellings, one in heaven, and the other in 'a meek and thankful heart. Which Almighty God grant to me, and to my honest scholar : and so you are welcome to Tottenham High Cross.

VeN. Well, master, I thank you for all your good directions; but for none more than this last, of thankfulness, which I hope I shall never forget. And pray let's now rest ourselves in this sweet shady arbour, which Nature herself has woven with her own fine finger; 'tis such a contexture of woodbines, sweetbriar, jessamine, and myrtle; and so interwoven, as will secure us both from the sun's violent heat and from the approaching shower. And being sat down, I will requite a part of your courtesies with a bottle of sack, milk, oranges, and sugar ; which, all put together, make a drink like nectar ; indeed, too good for any but us anglers. And so, master, here is a full glass to you of that liquor : and when you have pledged me I will repeat the verses which I promised you : it is a copy printed among some of Sir Henry Wotton's, and doubtless made either by him or by a lover of angling. Come, master, now drink a glass to me, and then I will pledge you, and fall to my repetition; it is a description of such country recreations as I have enjoyed since I had the happiness to fall into your company.

Quivering fears, heart-tearing cares,

Anxious sighs, untimely tears,

Fly, fly to courts,

Fly to fond worldlings' sports,

Where strain'd sardonic smiles are glosing still,

And Grief is forced to laugh against her will :

Where mirth's but mummery,

And sorrows only real be.

* Dr. Donne, as a reverend and learned friend of mine informs me. $-\mathrm{H}$. 
Fly from our country pastimes, fly,

Sad troops of human misery.

Come, serene looks,

Clear as the crystal brooks,

Or the pure azured heaven that smiles to see

The rich attendance on our poverty ;

Peace and a secure mind,

Which all men seek, we only find.

Abused mortals! did you know

Where joy, heart's ease, and comforts grow,

You'd scorn proud towers,

And seek them in these bowers;

Where winds, sometimes, our woods perhaps may shake, But blustering care could never tempest make,

Nor murmurs e'er come nigh us,

Saving of fountains that glide by us.

Here's no fantastic mask nor dance, But of our kids that frisk and prance ;

Nor wars are seen,

Unless upon the green

Two harmless lambs are butting one the otherWhich done, both bleating run, each to his mother; And wounds are never found,

Save what the ploughshare gives the ground.

Here are no entrapping baits, To hasten to too hasty fates,

Unless it be

The fond credulity

Of silly fish, which (worldling-like) still look

Upon the bait, but never on the hook;

Nor envy, less among

The birds, for prize of their sweet song.

Go, let the diving negro seek

For gems, hid in some forlorn creck:

We all pearls scorn,

Save what the dewy morn

Congeals upon each little spire of grass,

Which careless shepherds beat down as they pass;

And gold ne'er here appears,

Save what the yellow Ceres bears. 
Bless'd silent groves, O may you be,

For ever, mirth's best nursery !

May pure contents

For ever pitch their tents

Upon these downs, these meads, these rocks, these mountains,

And peace still slumber by these purling fountains;

Which we may every year

Meet, when we come a-fishing here!

Pisc. Trust me, scholar, I thank you heartily for these verses : they be choicely good, and doubtless made by a lover of angling. Come, now, drink a glass with me, and I will requite you with another very good copy : it is a farewell to the vanities of the world, and some say written by Sir Harry Wotton, who I told you was an excellent angler. But let them be writ by whom they will, he that writ them had a brave soul, and must needs be possessed with happy thoughts at the time of their composure.

Farewell, ye gilded follies, pleasing troubles !

Farewell, ye honour'd rags, ye glorious bubbles !

Fame's but a hollow echo-gold, pure clay-

Honour, the darling but of one short day-

Beauty, th' eye's idol, but a damask'd skin-

State, but a golden prison, to live in,

And torture free-born minds-embroider'd trains,

Merely but pageants for proud swelling veins-

And blood allied to greatness is alone

Inherited, not purchased, nor our own.

Fame, honour, beauty, state, train, blood, and birth, Are but the fading blossoms of the earth.

I would be great, but that the sun doth still Level his 1 ays against the rising hill-

I would be high, but see the proudest oak

Most subject to the rending thunder-stroke-

I would be rich, but see men (too unkind)

Dig in the bowels of the richest mind-

I would be wise, but that I often see

The fox suspected, whilst the ass goes free- 
I would be fair, but see the fair and proud, Like the bright sun, oft setting in a cloudI would be poor, but know the humble grass Still trampled on by each unworthy assRich, hated-wise, suspected-scorn'd, if poorGreat, fear'd-fair, tempted-high, still envied more :

I have wish'd all ; but now I wish for neither, Great, high, rich, wise, nor fair-poor I'II be rather.

Would the World now adopt me for her heirWould beauty's queen entitle me the fairFame speak me Fortune's minion-could I " vie Angels" with India *-with a speaking eye Command bare heads, bow'd knees, strike justice dumb, As well as blind and lame, or give a tongue To stones by epitaphs-be call'd "great master,"

In the loose rhymes of every poetasterCould I be more than any man that lives, Great, fair, rich, wise, all in superlativesYet I more freely would these gifts resign, Than ever Fortune would have made them mine; And hold one minute of this holy leisure Beyond the riches of this empty pleasure !

Welcome, pure thoughts! welcome, ye silent groves ! These guests, these courts, my soul most dearly loves ! Now the wing'd people of the sky shall sing My cheerful anthems to the gladsome spring :

A prayer-book, now, shall be my looking-glass, In which I will adore sweet virtue's face.

Here dwell no hateful looks, no palace cares, No broken vows dwell here, nor pale-faced fears ;

* An angel is a coin, value ten shillings. The words, to vie angels, are a periphrasis, and signify to compare wealth. In the old ballad of "The Beggar's Daughter of Bethnal Green," a competition of this kind is introduced: a young knight, about to marry the beggar's daughter, is dissuaded from so unequal a mateh by some gentlemen, lis relations, who urge the poverty of her father: the beggar challenges them to drop angels with him, and fairly empties the purses of them all. The contest, and its issue, are related in the well-known ballad beginning,-

"Then spake the blind beggar, "Although I be poore,

Yett rayle not against my child at my own door :

Though shee be no decked in velvet and pearle,

Yett I will dropp angells with you for my girle.' "- $\mathrm{H}$. 
Then here I'll sit, and sigh my hot love's folly, And learn t' affect a holy melancholy :

And if contentment be a stranger,-then

I'll ne'er look for it, but in heaven, again.

VEN. Well, master, these verses be worthy to keep a room in every man's memory. I thank you for them ; and I thank you for your many instructions, which (God willing) I will not forget. And as St. Austin, in his Confessions (book iv. chap. 3) commemorates the kindness of his friend Verecundus, for lending him and his companion a country house; because there they rested and enjoyed themselves, free from the troubles of the world : so, having had the like advantage, both by your conversation and the art you have taught me, I ought ever to do the like; for, indeed, your company and discourse have been so useful and pleasant, that, I may truly say, I have only lived since I enjoyed them and turned angler, and not before. Nevertheless, here I must part with you, here in this now sad place where I was so happy as first to meet you : but I shall long for the ninth of May; for then I hope again to enjoy your beloved company, at the appointed time and place. And now I wish for some somniferous potion, that might force me to sleep away the intermitted time, which will pass away with me as tediously, as it does with men in sorrow; nevertheless I will make it as short as I can by my hopes and wishes. And, my good master, I will not forget the doctrine which you told me Socrates taught his scholars, that they should not think to be honoured so much for being philosophers, as to honour philosophy by their virtuous lives. You advised me to the like concerning angling, and I will endeavour to do so ; and to live like those many worthy men, of which you made mention in the former part of your discourse. This is my firm resolution; and as a pious man advised his friend, that to beget mortification he should frequent churches, and view monuments, and 
charnel-houses, and then and there consider, how many dead bodies time had piled up at the gates of death: so when I would beget content, and increase confidence in the power, and wisdom, and providence of Almighty God, I will walk the meadows by some gliding stream, and there contemplate the lilies that take no care, and those very many other various little living creatures, that are not only created but fed, man knows not how, by the goodness of the God of Nature, and therefore trust in Him. This is my purpose; and so, let everything that hath breath praise the Lord: and let the blessing of St. Peter's Master be with mine.

'Pisc. And upon all that are lovers of virtue, and dare trust in His providence, and be quiet, and go a-angling.

"Study to Be Quiet"-1 Thess. iv. 11. 



\title{
THE
}

\section{COMPLETE ANGLER}

\section{PART THE SECOND}

\author{
BEING
}

INSTRUCTIONS

HOW TO ANGLE FOR A TROUT OR GRAYLING

IN A CLEAR STREAM

Qui mihi non credit, faciat licet ipse periclum :

Et fuerit seriptis aquior ille meis. 



\section{MR. IZAAK WALTON, THE ELDER}

Sir,-Being you were pleased, some years past, to grant me your free leave to do what I have here attempted; and observing you never retract any promise when made in favour of your meanest friends; I accordingly expect to see these following particular directions for the taking of a trout, to wait upon your better and more general rules for all sorts of angling. And though mine be neither so perfect, so well digested, nor indeed so handsomely couch'd as they might have been, in so long a time as since your leave was granted, yet I dare affirm them to be generally true: and they had appeared too in something of a neater dress, but that I was surprised with the sudden news of a sudden new edition of your Compleat Angler, so that, having little more than ten days' time to turn me in, and rub up my memory (for, in truth, I have not, in all this long time, though I have often thought on't, and almost as often resolved to go presently about it), I was forced, upon the instant, to scribble what I here present you: which I have also endeavoured to accommodate to your own method. And, if mine be clear enough for the honest brothers of the angle readily to understand, which is the only thing I aim at, then I have my end, and shall need to make no further apology ; a writing of this kind not requiring, if I were master of any such thing, any eloquence to set. it off, and recommend it; so that if you, in your better judgment, or kindness rather, can allow it passable for a thing of this nature, you will then do me the hollour if the cypher fixed and carved in the front of my little fishing-house, may be here explained: and to permit me to attend you in public, who, in private, have ever been, am, and ever resolve to be,

Sir,

Your most affectionate son and servant,

CHARLES COTTON.

BerEsford,

10th of March, 1675-6. 
MY MOST HONOURED FRIEND

\section{CHARLES COTTON, ESQ.}

SIR,-You now see I have returned you your very pleasant and useful discourse of The Art of Fly-fishing, printed just as it was sent me ; for I have been so obedient to your desires, as to endure all the praises you have ventured to fix upon me in it. And when I have thanked you for them, as the effects of an undissembled love, then, let me tell you, Sir, that I will readily endeavour to live up to the character you have given of me, if there were no other reason, yet for this alone, that you, that love me so well, and always think what you speak, may not, for my sake, suffer by a mistake in your judgment.

And, Sir, I have ventured to fill a part of your margin, by way of paraphrase, for the reader's elearer understanding the situation both of your fishing-house and the pleasantness of that you dwell in. And I have ventured also to give him a Copy of Verses that you were pleased to send me, now some years past, in which he may see a good picture of both; and so much of your own mind too, as will make any reader, that is blessed with a generous soul, to love you the better. I confess, that for doing this you may justly judge me too bold: if you do, I will say so too; and so far commute for my offence, that, though I be more than a hundred miles from you, and in the eighty-third year of my age, yet I will forget both, and next month begin a pilgrimage to beg your pardon; for I would die in your favour, and till then will live,

Sir,

Your most affectionate father and friend, IZAAK WALTON.

London, April 29, 1676. 


\title{
THE COMPLETE ANGLER
}

\section{PART THE SECOND}

\author{
CHAPTER I \\ Piscator junior, and Viator
}

\section{[Jfirst Day]}

Pisc. You are happily overtaken, Sir ; may a man be so bold as to enquire how far you travel this way?

Viat. Yes sure, Sir, very. freely; though it be a question I cannot very well resolve you, as not knowing myself how far it is to Ashborn, where I intend to-night to take up my inn.

PIsc. Why then, Sir, seeing I perceive you to be a stranger in these parts, I shall take upon me to inform you, that from the town you last came through, called Brelsford,* it is five miles; and you are not yet above half a mile on this side.

VIAT. So much? I was told it was but ten miles from Derby ; and, methinks, I have rode almost so far already.

P1sc. O Sir, find no fault with large measure of good land, which Derbyshire abounds in, as much as most counties of England.

Viar. It may be so; and good land, I confess, affords a pleasant prospect: but, by your good leave,

* Now spelt " Brailsford." It is a mere road-side village. Brailsford brook was once celebrated for its trout. I cannot speak highly of it now.-E. 
Sir, large measure of foul way is not altogether so acceptable.

PIsc. True, Sir ; but the foul way serves to justify the fertility of the soil, according to the proverb, "There is good land where there is foul way" ; and is of good use to inform you of the riches of the country you are come into, and of its continual travel and traffic to the country town you came from : which is also very observable by the fulness of its road, and the loaden horses you meet everywhere upon the way.

Viat. Well, Sir, I will be content to think as well of your country as you would desire; and I shall have a great deal of reason both to think and to speak very well of you, if I may obtain the happiness of your company to the fore-mentioned place, provided your affairs lead you that way, and that they will permit you to slack your pace, out of complacency to a traveller utterly a stranger in these parts, and who am still to wander further out of my own knowledge.

Pisc. Sir, you invite me to my own advantage, and I am ready to attend you, my way lying through that town; but my business, that is, my home, some miles beyond it: however, I shall have time enough to lodge you in your quarters, and afterward to perform my own journey. In the meantime, may I be so bold as to enquire the end of your journey?

Viat. 'Tis into Lancashire, Sir; and about some business of concern to a near relation of mine; for I assure you, I do not use to take such long journeys as from Essex upon the single account of pleasure.

Pisc. From thence, Sir! I do not then wonder you should appear dissatisfied with the length of the miles, and the foulness of the way: though I am sorry you should begin to quarrel with them so soon; for believe me, Sir, you will find the miles much longer, and the way much worse, before you come to your journey's end. 
VIAT. Why! truly, Sir! for that I am prepared to expect the worst; but methinks the way is mended since I had the good fortune to fall into your good company.

Pisc. You are not obliged to my company for that, but because you are already past the worst, and the greatest part of your way to your lodging.

VIAT. I am very glad to hear it, both for the ease of myself and my horse; but especially, because I may then expect a freer enjoyment of your conversation : though the shortness of the way will, I fear, make me lose it the sooner.

PIsc. That, Sir, is not worth your care: and I am sure you deserve much better for being content with so ill company. But we have already talked away two miles of your journey; for, from the brook before us, that runs at the foot of this sandy hill, you have but three miles to Ashborn.

VIAT. I meet, everywhere in this country, with these little brooks; and they look as if they were full of fish : have they not trouts in them?

PIsc. That is a question which is to be excused in a stranger, as you are : otherwise, give me leave to tell you, it would seem a kind of affront to our country, to make a doubt of what we pretend to be famous for, next, if not before, our malt, wool, lead, and coal ; for you are to understand, that we think we have as many fine rivers, rivulets, and brooks, as any country whatever; and they are all full of trouts, and some of them the best, it is said, by many degrees, in England.

Viat. I was first, Sir, in love with you; and now shall be so enamoured of your country by this account you give me of it, as to wish myself a Derbyshire man, or at least that I might live in it: for you must know I am a pretender to the angle, and, doubtless, a trout affords the most pleasure to the angler of any sort of 
fish whatever; and the best trouts must needs make the best sport : but this brook, and some others I have met with upon this way, are too full of wood for that recreation.

Pisc. This, Sir! why this, and several others like it, which you have passed, and some that you are like to pass, have scarce any name amongst us : but we can shew you as fine rivers, and as clear from wood, or any other incumbrance to hinder an angler, as any you ever saw; and for clear beautiful streams, Hantshire itself, by Mr. Izaak Walton's good leave, can shew none such; nor I think any country in Europe.*

VIAT. You go far, Sir, in the praise of your country rivers, and I perceive have read Mr. Walton's Compleat Angler, by your naming of Hantshire; and I pray what is your opinion of that book ?

Pisc. My opinion of Mr. Walton's book is the same with every man's that understands anything of the art of angling, that it is an excellent good one, and that the fore-mentioned gentleman understands as much of fish, and fishing, as any man living : but I must tell you further, that I have the happiness to know his person, and to be intimately acquainted with him, and in him to know the worthiest man, and to enjoy the best, and the truest friend any man ever had; nay, I shall yet acquaint you further, that he gives me leave to call him Father, and I hope is not yet ashamed to own me for his adopted Son.

VIAT. In earnest, Sir, I am ravished to meet with a friend of Mr. Izaak Walton's, and one that does him so much right in so good and true a character; for

* This praise will not hold good now. Apart from certain preserved portions of the Dove, the other Derbyshire rivers are not first-rate. They certainly are very pretty clear streams, and are difficult to ny-fish; the well-known Lathkil, on account of its extreme limpidness, the most difficult of all. The trout of this brook are the most highly-coloured in the county, but not the best flavoured. $-\mathrm{E}$. 
I must boast to you, that I have the good fortune to know him too, and came acquainted with him much after the same manner I do with you; that he was my Master, who first taught me to love angling, and then to become an angler; and to be plain with you, I am the very man deciphered in his book under the name of Venator; for I was wholly addicted to the chace, till he taught me as good, a more quiet, innocent, and less dangerous diversion.

PIsc. Sir, I think myself happy in your acquaintance, and before we part shall entreat leave to embrace you ; you have said enough to recommend you to my best opinion: for my father Walton will be seen twice in no man's company he does not like, and likes none but such as he believes to be very honest men; which is one of the best arguments, or at least of the best testimonies I have, that I either am, or that he thinks me, one of those, seeing I have not yet found him weary of me.

VIAT. You speak like a true friend, and in doing so render yourself worthy of his friendship. May I be so bold as to ask your name?

Pisc. Yes surely, Sir, and if you please a much nicer question; my name is — , and I intend to stay long enough in your company, if I find you do not dislike mine, to ask your's too. In the meantime, because we are now almost at Ashborn, I shall freely and bluntly tell you, that I am a brother of the angle too, and, peradventure, can give you some instructions how to angle for a trout in a clear river, that my father Walton himself will not disapprove, though he did either purposely omit, or did not remember them,* when you and he sat discoursing under the sycamore tree. [See part i. p 104.] And, being

* The plain truth is, that Walton did not understand angling for " a trout in a clear stream," viz., fly-fishing for it. Cotton knew this well, but was too much of a courteous "cavalier" to say so bluntly:-E. 
[seeing] you have already told me whither your journey is intended, and that I am better acquainted with the country than you are; I will heartily and earnestly entreat you will not think of staying at this town, but go on with me six miles farther to my house,* where you shall be extremely welcome; it is directly in your way, we have day enough to perform our journey, and, as you like your entertainment, you may there repose yourself a day or two, or as many more as your occasions will permit, to recompense the trouble of so much a longer journey.

VIAT. Sir, you surprise me with so friendly an invitation upon so short acquaintance; but how advantageous soever it would be to me, and that my haste, perhaps, is not so great but it might dispense with such a divertisement as I promise myself in your company, yet I cannot, in modesty, accept your offer, and must therefore beg your pardon : I could otherwise, I confess, be glad to wait upon you, if upon no other account but to talk of Mr. I. Walton, and to receive those instructions you say you are able to give me for the deceiving a trout; in which art I will not deny but that I have an ambition to be one of the greatest deceivers: though I cannot forbear freely to tell you, that I think it hard to say much more than has been read to me upon that subject.

Pisc. Well, Sir, I grant that, too ; but you must know that the variety of rivers require different ways of angling: however, you shall have the best rules I am able to give, and I will tell you nothing I have not made myself as certain of, as any man can be in a thirty years' experience (for so long I have been a dabbler in that art); and that if you please to stay a few days, you shall, in a very great measure, see made good to you. But of that hereafter ;

* Beresford Hall, situate a little to the north of Dovedale. In 1838 it was a large farm-house, and the property of the Marquis of Beresford. Between it and the river side Cotton's fishing-house was still standing.-E. 
and now, Sir, if I am not mistaken, I have half overcome you; and that I may wholly conquer that modesty of yours, I will take upon me to be so familiar as to say, you must accept my invitation, which, that you may the more easily be persuaded to do, I will tell you that my house stands upon the margin of one of the finest rivers for trout and grayling in England; that I have lately built a little fishing-house upon it, dedicated to anglers, over the door of which you will see the two first letters of my father Walton's name and mine twisted in cipher; that you shall lie in the same bed he has sometimes been contented with, and have such country entertainment as my friends sometimes accept, and be as welcome, too, as the best friend of them all.

VIAT. No doubt, Sir, but my master Walton found good reason to be satisfied with his entertainment in your house; for you who are so friendly to a mere stranger, who deserves so little, must needs be exceeding kind and . free to him who deserves so much.

PIsc. Believe me, no: and such as are intimately acquainted with that gentleman know him to be a man who will not endure to be treated like a stranger. So that his acceptation of my poor entertainment has ever been a pure effect of his own humility and good-nature, and nothing else. But, Sir, we are now going down the Spittle Hill into the town; and therefore let me importune you suddenly to resolve, and (most earnestly) not to deny me.

Viat. In truth, Sir, I am so overcome by your bounty, that I find I cannot, but must render myself wholly to be disposed of by you.

PIsc. Why that's heartily and kindly spoken, and I as heartily thank you. And, being [seeing] you have abandoned yourself to my conduct, we will only call and drink a glass on horseback at the Talbot, and away. 
VIAT. I attend you. But what pretty river is this, that runs under this stone bridge? Has it a name?

Pisc. Yes, it is called Henmore ; ${ }^{*}$ and has in it both trout and grayling; but you will meet with one or two better anon. And so soon as we are past through the town, I will endeavour by such discourse as best likes you, to pass away the time till you come to your ill quarters.

VIAT. We can talk of nothing with which I shall be more delighted than of rivers and angling.

Pisc. Let those be the subjects then; but we are now come to the Talbot. What will you drink, Sir, ale, or wine?

Viat. Nay, I am for the country liquor, Derbyshire ale, if you please ; for a man should not, methinks, come from London to drink wine in the Peak.

Pisc. You are in the right; and yet let me tell you, you may drink worse French wine in many taverns in London, than they have sometimes at this house. What ho! bring us a flagon of your best ale ; and now, Sir, my service to you, a good health to the honest gentleman you know of, and you are welcome into the Peak.

Viat. I thank you, Sir, and present you my service again, and to all the honest brothers of the angle.

Pisc. I'll pledge you, Sir: so, there's for your ale, and farewell. Come, Sir, let us be going, for the sun grows low, and I would have you look about you as you ride; for you will see an odd country, and sights that will seem strange to you.

* Now called Shoo Brook, without a trout or grayling in it. 'Tis a mere ditch of running water. in which the little boys of Ashbourn commence their angling career by fishing for minnows.-E. 


\section{CHAPTER iI}

\section{[Jfirst Day]}

PIsc. So, Sir, now we have got to the top of the hill out of town, look about you, and tell me how you like the country.

Viat. Bless me, what mountains are here! Are we not in Wales ?

PIsc. No, but in almost as mountainous a country ; and yet these hills, though high, bleak, and craggy, breed and feed good beef and mutton, above ground, and afford good store of lead within.

Viat. They had need of all those commodities to make amends for the ill landskip : but I hope our way does not lie over any of these, for I dread a precipice.

Pisc. Believe me, but it does, and down one especially, that will appear a little terrible to a stranger : though the way is passable enough, and so passable, that we who are natives of these mountains, and acquainted with them, disdain to alight.

VIAT. I hope, though, that a foreigner is privileged to use his own discretion, and that I may have the liberty to entrust my neck to the fidelity of my own feet, rather than to those of my horse, for I have no more at home.

PIsc. 'Twere hard else. But in the meantime, I think 'twere best, while this way is pretty even, to mend our pace, that we may be past that hill I speak of ; to the end your apprehension may not be doubled, for want of light to discern the easiness of the descent.

VIAT. I am willing to put forward as fast as my beast 
will give me leave, though I fear nothing in your company. But what pretty river is this we are going into?

PIsc. Why this, Sir, is called Bently Brook,* and is full of very good trout and grayling; but so encumbered with wood in many places, as is troublesome to an angler.

Viat. Here are the prettiest rivers, and the most of them in this country that ever I saw ; do you know how many you have in the country ?

PIsc. I know them all, and they were not hard to reckon, were it worth the trouble, but the most considerable of them I will presently name you. And to begin where we now are, for you must know we are now upon the very skirts of Derbyshire; we have first the River Dove, that we shall come to by and by, which divides the two counties of Derby and Stafford for many miles together; and is so called from the swiftness of its current, and that swiftness occasioned by the declivity of its course, and by being so straitened in that course betwixt the rocks ; by which, and those very high ones, it is, hereabout, for four or five miles, confined into a very narrow stream ; a river that from a contemptible fountain, which I can cover with my hat, by the confluence of other rivers, rivulets, brooks, and rills, is swelled, before it falls into Trent, a little below Eggington, where it loses the name, to such a breadth and depth as to be in most places navigable, were not the passage frequently interrupted with fords and weirs; and has as fertile banks as any river in England, none excepted. And this river, from its head for a mile or two, is a black water, as all the rest of the Derbyshire rivers of note originally are, for they all spring from the mosses; but is in a few miles travel so clarified by the addition of several clear and very great springs, bigger than itself, which gush out of the limestone rocks, that before it comes to my house, which is but six or seven miles

* Two miles beyond Ashbourn, and still not a bad stream for trout and grayling.-E. 
from its source, you will find it one of the purest crystalline streams you have seen.*

VIAT. Does Trent spring in these parts ?

PIsc. Yes, in these parts; not in this county, but somewhere towards the upper end of Staffordshire, I think not far from a place called Trentham; and thence runs down, not far from Stafford, to Wolsly Bridge, and washing the skirts and purlieus of the forest of Needwood, runs down to Burton in the same county; thence it comes into this, where we now are, and running by Swarkston and Dunnington, receives Derwent at Wildon; and, so, to Nottingham ; thence, to Newark ; and, by Gainsborough, to Kingston-upon-Hull, where it takes the name of Humber, and thence falls into the sea ; but that the map will best inform you.

VIAT. Know you whence this River Trent derives its name ?

Pisc. No, indeed ; and yet I have heard it often discoursed upon: when some have given its denomination from the forenamed Trentham, though that seems rather a derivative from it; others have said it is so called from thirty rivers that fall into it, and there lose their names ; which cannot be, neither, because it carries that name from its very fountain, before any other rivers fall into it : others derive it from thirty several sorts of fish that breed there; and that is the most likely derivation : but be it how it will, it is doubtless one of the finest rivers in

* Between Beresford Hall and Ashbourn lies Dove-dale, whose crested cliffs and swift torrents are again noticed by Mr. Cotton in his Wonders of the Peak. Through this singularly deep valley the Dove runs for about two miles, changing its course, its motion, and its appearance perpetually ; never less than ten, and rarely so inany as twenty yards in width; making a continued noise by rolling over or falling among loose stones. The rocks which form its sides, are heaved up in enormous piles, sometimes connected with each other and sometimes detached; some perforated in natural cavities, others adorned with foliage ; with here and there a tall rock, having nothing to relieve the bareness of its appearance but a mountainash flourishing at the top. The grandeur of its scenery is probably unrivalled in England. - $\mathrm{H}$. 
the world, and the most abounding with excellent salmon, and all sorts of delicate fish.*

Viat. Pardon me, Sir, for tempting you into this digression; and then proceed to your other rivers, for I am mightily delighted with this discourse.

Pisc. It was no interruption, but a very seasonable question : for Trent is not only one of our Derbyshire rivers, but the chief of them, and into which all the rest pay the tribute of their names, which I had, perhaps, forgot to insist upon, being got to the other end of the county, had you not awoke my memory. But I will now proceed. And the next river of note, for I will take them as they lie eastward from us, is the River Wye ; I say of note, for we have two lesser betwixt us and it, namely Lathkin and Bradford; of which Lathkin is, by many degrees, the purest and most transparent stream that I ever yet saw, either at home or abroad, and breeds, it is said, the reddest and the best trouts in England : but neither of these are to be reputed rivers, being no better than great/springs. The River Wye, then, has its source near unto Buxton, a town some ten miles hence, famous for a warm bath, and which you are to ride through in your way to Manchester; a black water too, at the

* There are no salmon in the Trent now, and not many trout and grayling. Its trout, though few, grow to a large size, sometimes, but very rarely as large as those of the Thames. It is an excellent river for pike, perch, barbel, chub, and other coarse fish. 1 do not think it produces thirty different sorts of fish. Many think the contrary, but have not specifically named them. Others maintain that it derives its name from having thirty (trente) tributaries, and agree that Milton's distich, in his well-known description of English rivers, should be read-

"Or Trent, who like an earth-born giant, spreads

Its thirty arms along the indented meads."

Instead of thirsty, the usual reading. I am inclined to think that thirsty is a graphical, or typographical error-that Milton wrote thirty, and was thinking when he did so of the earth-born (son of Colus and Terra) giant, Briareus, and his hundred arms. Walton inclines to the opinion that the Trent derives its name from thirty different sorts of fish found in it, and not because it is said to have thirty tributaries.-E. 
fountain, but, by the same reason with Dove, becomes very soon a most delicate clear river, and breeds admirable trout and grayling, reputed by those who, by living upon its banks, are partial to it, the best of any ; and this, running down by Ashford, Bakewell, and Hadden, at a town a little lower, called Rowsly, falls into Derwent, and there loses its name* The next in order is Derwent, a black water too, and that not only from its fountain, but quite through its progress, not having these crystal springs to wash and cleanse it which the two fore-mentioned have ; but abounds with trout and gravling, such as they are, towards its source, and with salmon below: and this river, from the upper and utmost part of the county, where it springs, taking its course by Chatsworth, Darley, Matlock, Derby, Burrow-Ash, and Awberson, falls into Trent at a place called Wildon, and there loses its name. The east side of this county of Derby is bounded by little inconsiderable rivers, as Awber, Eroways, and the like, scarce worth naming, but trouty too; and further we are not to enquire. But, Sir, I have carried you, as a man may say, by water, till we are now come to the descent of the formidable hill I told you of, at the foot of which runs the River Dove, which I cannot but love above all the rest; and therefore prepare yourself to be a little frighted.

Viat. Sir, I see you would fortify me, that I should not shame myself : but I dare follow where you please to lead me; and I see no danger yet; for the descent, methinks, is thus far green, even, and easy.

* By this it appears, that there are two rivers in England that bear the name of the Wye ; the former Wye, has, as well as the Severn, its head in the Plinlimmon Hills, on the borders of Montgomery and Cardiganshires; from whence, as its Latin name, Vaga, imports, wandering through part of Brecknockshire, it, near the Hay, enters Herefordshire; and at Mordiford, within four miles of Hereford, receives the Lug; from thence, passing on to Ross, it enters Monmouthshire, and falls into the Severn below Chepstow. It abounds with that small species of fish called last-springs; and also with grayling. $-\mathrm{H}$. 
Pisc. You will like it worse presently, when you. come to the brow of the hill; and now we are there, what think you ?

VIAT. What do I think? Why I think it is the strangest place that, ever sure, men and horses went down; and that, if there be any safety at all, the safest way is to alight.

Pisc. I think so too for you, who are mounted upon a beast not acquainted with these slippery stones; and though I frequently ride down, I will alight too to bear you company, and to lead you the way ; and, if you please, my man shall lead your horse.

VIAT. Marry, Sir, and thank you too: for I am afraid I shall have enough to do to look to myself ; and, with my horse in my hand should be in a double fear, both of breaking my neck, and my horse's falling on me ; for it is as steep as a penthouse.

Pisc. To look down from hence it appears so, I confess; but the path winds and turns, and will not be found so troublesome.

Viat. Would I were well down though! Hoist thee! there's one fair 'scape! these stones are so slippery I cannot stand! yet again! I think I were best lay my heels in my neck, and tumble down.

Pisc. If you think your heels will defend your neck, that is the way to be soon at the bottom; but give me your hand at this broad stone, and then the worst is past.

VIAT. I thank you, Sir, I am now past it, I can go myself. What's here the sign of a bridge? Do you use to travel with wheelbarrows in this country?

Pisc. Not that I ever saw, Sir. Why do you ask that question?

VIAT. Because this bridge certainly was made for nothing else; why a mouse can hardly go over it : 'tis not two fingers broad. 
PISc. You are pleasant, and I am glad to see you so : but I have rid over the bridge many a dark night.

VIAT. Why according to the French proverb, and 'tis a good one among a great many of worse sense and sound that language abounds in, Ce que Dieu garde, est bien gardé. "They whom God takes care of are in safe protection:" but, let me tell you, I would not ride over it for a thousand pounds, nor fall off it for two; and yet I think I dare venture on foot, though if you were not by to laugh at me, I should do it on all four.

Pisc. Well, Sir, your mirth becomes you, and I am glad to see you safe over, and now you are welcome into Staffordshire.

VIAT. How, Staffordshire! What do I there, trow? there is not a word of Staffordshire in all my direction.

Pisc. You see you are betrayed into it, but it shall be in order to something that will make amends; and 'tis but an ill mile or two out of your way.

VIAT. I believe all things, Sir, and doubt nothing. Is this your beloved River Dove? 'Tis clear and swift indeed, but a very little one.

PIsc. You see it, here, at the worst: we shall come to it anon again, after two miles riding, and so near as to lie upon the very banks.

Viat. Would we were there once : but I hope we have no more of these Alps to pass over.

Pisc. No, no, Sir, only this ascent before you, which you see is not very uneasy, and then you will no more quarrel with your way.

Viat. Well, if ever I come to London, of which many a man there, if he were in my place, would make a question, I will sit down and write my travels; and, like Tom Coriate,* print them at my own charge. Pray what do you call this hill we came down?

* Tom Coriate lived in the reign of King James the First ; and, as Wood calls him, was the whetstone of all the wits of that age : and, 100-I* 
Pisc. We call it Hanson Toot.

VIAT. Why, farewell, Hanson Toot! I'll no more on thee : I'll go twenty miles about first : Puh ! I sweat that my shirt sticks to my back.

Pisc. Come, Sir, now we are up the hill; and now how do you?

Viat. Why, very well, I humbly thank you, Sir, and warm enough, I assure you. What have we here, a church ? As I'm an honest man, a very pretty church ? Have you churches in this country, Sir ?

PIsc. You see we have: but had you seen none, why should you make that doubt, Sir ?

VIAT. Why, if you will not be angry, I'll tell you ; I thought myself a stage or two beyond Christendom.

PIsc. Come, come, we'll reconcile you to our country before we part with you, if shewing you good sport with angling will do it.

indeed, the allusions to him, and to the singular oddness of his character, are numberless. He travelled almost over Europe on foot; and in that tour walked 900 miles with one pair of shoes, which he got mended at Zurich. Afterwards he visited Turkey, Persia, and the Great Mogul's dominions, travelling in so frugal a manner, that-as he tells his mother, in a letter to her-in his ten months' travels, between Aleppo and the Mogul's court, he spent but three pounds sterling; living remarkably well for about twopence sterling a day; and of that three pounds he elsewhere says, he was cozened of no less than ten shillings sterling by certain Christians of the Armenian nation; so that, indeed, he spent but fifty shillings in his ten months' travels. In these his travels, he attained to great perfection both in the Persian and Indostan languages; in the former, he made and pronounced an oration to the Great Mogul ; and his skill in the latter, he took occasion to manifest in the following very signal instance. In the service of the English ambassador, then resident, was a woman of Indostan, a laundress, whose frequent practice it was to scold, brawl, and rail, from sunrising to sunset. This formidable shrew did Coriate one day undertake to scold with, in her own language; and succeeded so well in the attempt, that, by eight of the clock in the morning, he had totally silenced her, leaving her not a word to speak. Further it appears, that he was a zealous champion for the Christian religion against the Mahometans and the Pagans, in the defence whereof he sometimes risked his life. He died of the flux, occasioned by drinking sack at Surat, in 1617: having published his European travels in a quarto volume, which he called his Crudities; and to this circumstance the passage in the text is a manifest allusion.- $H$. 
Viat. My respect to you, and that together, may do much, Sir; otherwise, to be plain with you, I do not find myself much inclined that way.

PIsc. Well, Sir, your raillery upon our mountains has brought us almost home; and look you where the same river of Dove has again met us to bid you welcome, and to invite you to a dish of trouts to-morrow.

ViaT. Is this the same we saw at the foot of PenmenMaure? It is a much finer river here.

PIsc. It will appear yet much finer to-morrow. But look you, Sir, here appears the house, that is now like to be your inn, for want of a better.

Viat. It appears on a sudden, but not before 'twas looked for ; it stands prettily, and here's wood about it too, but so young, as appears to be of your own planting.

PIsc. It is so ; will it please you to alight, Sir ; and now permit me, after all your pains and dangers, to take you in my arms, and to assure you, that you are infinitely welcome.

VIAT. I thank you, Sir, and am glad with all my heart I am here ; for, in downright truth, I am exceeding weary.

PIsc. You will sleep so much the better; you shall presently have a light supper, and to bed. Come, Sirs, lay the cloth, and bring what you have presently, and let the gentleman's bed be made ready in the meantime, in my father Walton's chamber; and now, Sir, here is my service to you, and once more welcome.

Viat. Ay marry, Sir, this glass of good sack has refreshed me, and I'll make as bold with your meat, for the trot has got me a good stomach.

PIsc. Come, Sir, fall to then, you see my little supper is always ready when I come home; and I'll make no stranger of you.

VIaT. That your meal is so soon ready is a sign your servants know your certain hours, Sir; I confess 
I did not expect it so soon; but now 'tis here, you shall see I will make myself no stranger.

Prsc. Much good do your heart, and I thank you for that friendly word: and now, Sir, my service to you in a cup of More-Lands ale: for you are now in the More-Lands, but within a spit and a stride of the Peak; fill my friend his glass.

Viat. Believe me, you have good ale in the MoreLands, far better than that at Ashborn.*

Pisc. That it may soon be : for Ashborn has, which is a kind of a riddle, always in it the best malt, and the worst ale in England. Come, take away, and bring us some pipes, and a bottle of ale, and go to your own suppers. Are you for this diet, Sir?

Viat. Yes, Sir, I am for one pipe of tobacco; and I perceive your's is very good by the smell.

Pisc. The best I can get in London, I assure you. $\nmid$

* The name of this pretty town is variously written,-Ashborn, Ashbourn, Ashborne. The latter is the modern way of spelling it. -E.

† It should seem, by what Walton says, chap. $x$. part i., that he was a smoker : and the reader sees, by the passage in the text, that Piscator, by whom we are to understand Cotton himself, is so curious as to have his tobacco from London. But our piscatory disciple may do as he pleases. Smoking, or, as the phrase was, taking tobacco, was, in Queen Elizabeth's and her successor's time, esteemed the greatest of all foppery. Ben Jonson, who mortally hated it, has numberless sarcasms against smoking and smokers; all of which are nothing, compared to those contained in that work of our King James the First, A Counter-blast to Tobacco. Nor was the ordinary conversation of this monarch less fraught with reasons and invectives against the use of that weed, as will appear from the following saying of his, extracted from A Collection of Witty A pophthegnis, delivered by him and others, at several times, and on sundry occasions, published in $12 \mathrm{mo}$. 1671. "That tobacco was the lively image and pattern of hell ; for that it had, by allusion, in it all the parts and vices of the world whereby hell may be gained; to wit : First, It was a smoke; so are the vanities of this world. Secondly, It delighteth them who take it; so do the pleasures of the world delight the men of the world. Thirdly, It maketh men drunken and light in the head; so do the vanities of the world : men are drunken therewith. Fourthly, He that taketh tobacco saith he cannot leave it, it doth bewitch him : even so the pleasures of the world make men loath to leave them, they are for the most part so enchanted with them. And further, besides all this, it is like hell in 
But, Sir, now you have thus far complied with my designs, as to take a troublesome journey into an ill country, only to satisfy me; how long may I hope to enjoy you ?

Viat. Why truly, Sir, as long as I conveniently can; and longer, I think, you would not have me.

PISc. Not to your inconvenience by any means, Sir : but I see you are weary, and therefore I will presently wait on you to your chamber, where, take counsel of your pillow; and, to-morrow resolve me. Here, take the lights; and pray follow them, Sir: Here you are like to lie; and now I have showed you your lodging, I beseech you, command any thing you want, and so I wish you good rest.

Viat. Good night, Sir.*

the very substance of it, for it is a stinking loathsome thing; and so is hell. And further, his majesty professed that, were he to invite the devil to dinner, he should have three dishes; 1 . A pig; 2. A pole of ling and mustard ; and 3. A pipe of tobacco for digesture." In Herefordshire, to signify the last or concluding pipe that any one means to smoke at a sitting, they use the term a Kemble pipe, alluding to a man of the name of Kemble, who in the cruel persecution under that merciless bigot Queen Mary, being condemned for heresy, in his walk of some miles from the prison to the stake, amidst a crowd of weeping friends, with the tranqullity and fortitude of a primitive martyr, smoked a pipe of tobacco.- $\mathrm{H}$.

* The gentlemanly hospitality of Piscator, by whom we are here to understand Mr. Cotton himself, in his behaviour to a stranger, manifested in the foregoing part of the dialogue, and in this instance of courtesy, is well wortl noting.- $\mathrm{H}$. 


\section{CHAPTER III}

\section{[Jecond Day]}

Pisc. Good morrow, Sir ; what! up and drest so early ?

VIat. Yes, Sir, I have been drest this half hour; for I rested so well, and have so great a mind either to take, or to see a trout taken in your fine river, that I could no longer lie a-bed.

PIsc. I am so glad to see you so brisk this morning, and so eager of sport; though I must tell you, this day proves so calm, and the sun rises so bright, as promises no great success to the angler; but, however, we'll try, and, one way or other, we shall sure do something. What will you have to your breakfast, or what will you drink this morning?

Viat. For breakfast, I never eat any, and for drink am very indifferent; but if you please to call for a glass of ale, I'm for you; and let it be quickly, if you please, for I long to see the little fishing-house you spoke of, and to be at my lesson.

Pisc. Well, Sir, you see the ale is come without calling; for though I do not know your's, my people know my diet, which is always one glass so soon as I am drest, and no more, till dinner : and so my servants have served you.

Viat. My thanks! And now, if you please, let us look out this fine morning.

Pisc. With all my heart. Boy, take the key of my fishing-house, and carry down those two angle-rods in the hall window, thither, with my fish-pannier, pouch, 
and landing-net; and stay you there till we come. Come, Sir, we'll walk after, where, by the way, I expect you should raise all the exceptions against our country you can.

VIat. Nay, Sir, do not think me so ill-natured nor so uncivil : I only made a little bold with it last night to divert you, and was only in jest.

Pisc. You were then in as good earnest as I am now with you : but had you been really angry at it, I could not blame you: for, to say the truth, it is not very taking at first sight. But look you, Sir, now you are abroad, does not the sun shine as bright here as in Essex, Middlesex, or Kent, or any of your southern counties?

Viat. It is a delicate morning indeed; and I now think this a marvellous pretty place.

PIsc. Whether you think so or no, you cannot oblige me more than to say so; and those of my friends who know my humour, and are so kind as to comply with it, usually flatter me that way. But look you, Sir, now you are at the brink of the hill, how do you like my river, the vale it winds through like a snake, and the situation of my little fishing-house ?

VIAT. Trust me, 'tis all very fine, and the house seems at this distance a neat building.

PIsc. Good enough for that purpose : and here is a bowling-green too, close by it; so, though I am myself no very good bowler, I am not totally devoted to my own pleasure, but that I have also some regard to other men's. And now, Sir, you are come to the door, pray walk in, and there we will sit and talk as long as you please.

Viat. Stay, what's here over the door? Piscatoribus Sacrum. Why then, I perceive I have some title here; for I am one of them, though one of the worst; and here below it is the cypher too you spoke of, and 
'tis prettily contrived. Has my master Walton ever been here to see it, for it seems new built?*

PIsc. Yes, he saw it cut in the stone, before it was set up; but never in the posture it now stands; for the house was but building when he was last here, and not raised so high as the arch of the door. And I am afraid he will not see it yet; for he has lately writ me word, he doubts his coming down this summer; which, I do assure you, was the worst news he could possibly have sent me.

VIAT. Men must sometimes mind their affairs to make more room for their pleasures: and 'tis odds he is as much displeased with the business that keeps him from you, as you are that he comes not. But I am most pleased with this little house of any thing I ever saw: it stands in a kind of peninsula too, with a delicate clear river about it. I dare hardly go in, lest I should not like it so well within as without: but, by your leave, I'll try. Why, this is better and better, fine lights, fine wainscoted, and all exceeding neat, with a marble table and all in the middle!

Pisc. Enough, Sir, enough; I have laid open to you the part where I can worst defend myself, and now

* I have been favoured with an accurate description of this fishinghouse, by a person, who, being in that country, with a view to oblige me, went to see it. The account he gave of it is, that it is of stone, and the room inside a cube of fifteen feet; that it is paved with black and white marble, and that in the middle is a square black marble table supported by two stone feet. The room is wainscoted with curious mouldings that divide the pannels up to the ceiling. In the larger pannels are represented, in painting, some of the most pleasant of the adjacent scenes, with persons fishing; and in the smaller, the various sorts of tackle and implements used in angling. In the farther corner, on the left, is a fire-place with a chimney; on the right, a large beaufet, with folding-doors, whereon are the portraits of Mr. Cotton, with a boy servant, and Walton, in the dress of the time. Underneath is a cupboard; on the door whereof the figures of a trout and a grayling are well portrayed. The edifice is at this time (1784) in but indifferent condition; the paintings, and even the wainscoting, in many places, being much decayed.-Hawkins (son of Sir John). 
you attack me there. Come, boy, set two chairs; and whilst I am taking a pipe of tobacco, which is always my breakfast, we will, if you please, talk of some other subject.

Viat. None fitter, then, Sir, for the time and place, than those instructions you promised.

Pisc. I begin to doubt, by something I discover in you, whether I am able to instruct you or no; though, if you are really a stranger to our clear northern rivers, I still think I can : and therefore, since it is yet too early in the morning at this time of the year, to-day being but the seventh of March, to cast a fly upon the water, if you will direct me what kind of fishing for a trout I shall read you a lecture on, I am willing and ready to obey you.

VIat. Why, Sir, if you will so far oblige me, and that it may not be too troublesome to you, I would entreat you would run through the whole body of it; and I will not conceal from you that I am so far in love with you, your courtesy, and pretty More-Land seat, as to resolve to stay with you long enough by intervals, for I will not oppress you to hear all you can say upon that subject.

Pisc. You cannot oblige me more than by such a promise : and therefore, without more ceremony, I will begin to tell you, that my father Walton having read to you before, it would look like a presumption in me (and, peradventure, would do so in any other man), to pretend to give lessons for angling after him, who, I do really believe, understands as much of it at least as any man in England, did I not preacquaint you, that I am not tempted to it by any vain opinion of myself, that I am able to give you better directions; but having, from my childhood, pursued the recreation of angling in very clear rivers, truly I think by much, some of them at least, the clearest in this kingdom, and the manner of angling here with us, by reason of that exceeding clearness, being something different from the method commonly used in 
others, which by being not near so bright, admit of stronger tackle, and allow a nearer approach to the stream; I may peradventure give you some instructions that may be of use, even in your own rivers, and shall bring you acquainted with more flies, and shew you how to make them, and with what dubbing too, than he has taken notice of in his Compleat Angler.

Viat. I beseech you, Sir, do: and if you wiii lend me your steel, I will light a pipe the while; for that is commonly my breakfast in a morning too. 


\section{CHAPTER IV}

\section{[รecond Dap]}

PISc. Why then, Sir, to begin methodically, as a master in any art should do; and I will not deny but that I think myself a master in this, I shall divide angling for trout or grayling into these three ways; at the top, at the bottom, and in the middle. Which three ways, though they are all of them, as I shall hereafter endeavour to make it appear, in some sort common to both those kinds of fish, yet are they not so generally and absolutely so, but that they will necessarily require a distinction, which, in due place, I will also give you.

That which we call angling at the top, is with a fly; at the bottom, with a ground-bait; in the middle, with a minnow or ground-bait.

Angling at the top is of two sorts ; with a quick [live] fly, or with an artificial fly.

That we call angling at the bottom is also of two sorts; by the hand, or with a cork or float.

That we call angling in the middle is also of two sorts; with a minnow for a trout, or with a ground-bait for a grayling.*

Of all which several sorts of angling, I will, if you can have the patience to hear me, give you the best account I can.

VIAT. The trouble will be yours, and mine the pleasure and the obligation: I beseech you therefore to proceed.

PIsc. Why then, first of fly-fishing.

* Angling " in the middle," means trolling and spinning. Fishing with a ground-bait for grayling is not angling at the middle, but at the bottorn. There is a method of fisling for grayling and other fish called " sinking and drawing," which consists in part of fishing at the bottom, the middle, and nearly at the top. 


\section{CHAPTER V \\ OF FLY-FISHING}

\section{[Fecond פay]}

Pisc. Fly-fishing, or fishing at the top, is, as I said before, of two sorts; with a natural and living fly, or with an artificial and made fly.

First then, of the natural fly : of which we generally use but two sorts; and those but in the two months of May and June only; namely, the green drake and the stone-fly: though I have made use of a third, that way, called the camlet-fly, with very good success, for grayling, but never saw it angled with by any other, after this manner, my master only excepted, who died many years ago, and was one of the best anglers that ever I knew.

These are to be angled with, with a short line, not much more than half the length of your rod, if the air be still; or with a longer very near, or all out, as long as your rod, if you have any wind to carry it from you. And this way of fishing we call daping, dabbing, or dibbing ; wherein you are always to have your line flying before you up or down the river, as the wind serves, and to angle as near as you can to the bank of the same side whereon you stand, though where you see a fish rise near you, you may guide your quick [live] fly over him, whether in the middle, or on the contrary side; and if you are pretty well out of sight, either by kneeling or the interposition of a bank or bush, you may almost be sure to raise, and take him too, if it be presently done; the fish will, other- 
wise, peradventure be removed to some other place, if it be in the still deeps, where he is always in motion, and roving up and down to look for prey, though, in a stream, you may always almost, especially if there be a good stone near, find him in the same place. Your line ought in this case to be three good hairs next the hook, both by reason you are in this kind of angling to expect the biggest fish, and also that wanting length to give him line after he is struck, you must be forced to tug for it; to which I will also add, that not an inch of your line being to be suffered to touch the water in dibbing, it may be allowed to be the stronger. I should now give you a description of those flies, their shape and colour, and then give you an account of their breeding, and withal shew you how to keep and use them ; but shall defer them to their proper place and season.

VIAT. In earnest, Sir, you discourse very rationally of this affair,* and I am glad to find myself mistaken in you; for in truth I did not expect so much from you.

Pisc. Nay, Sir, I can tell you a great deal more than this, and will conceal nothing from you. But I must now come to the second way of angling at the top, which is with an artificial fly, which also I will shew you how to make before I have done, but first shall acquaint you, that with this you are to angle with a line longer by a yard and a half, or sometimes two yards, than your rod; and with both this and the other, in a still day in the streams, in a breeze that curls the water in the still deeps, where (excepting in May and June, that the best trouts will lie in shallow streams to watch for prey, and even then too) you are like to hit the best fish.

For the length of your rod, you are always to be governed by the breadth of the river you shall chuse to

* This compliment is well-deserved : Cotton understood " daping, dabbing, or dibbing " well, and teaches it soundly.-E. 
angle at; and for a trout-river, one of five or six yards long* is commonly enough ; and longer, though never so neatly and artificially made, it ought not to be, if you intend to fish at ease; and if otherwise, where lies the sport?

Of these, the best that ever I saw are made in Yorkshire, which are all of one piece ; that is to say, of several, six, eight, ten, or twelve pieces, so neatly pieced, and tied together with fine thread below, and silk above, as to make it taper like a switch, and to ply with a true bent to your hand; and these too are light, being made of firwood for two or three lengths nearest to the hand, and of other wood nearer to the top, that a man might very easily manage the longest of them that ever I saw, with one hand ; and these, when you have given over angling for a season, being taken to pieces, and laid up in some dry place, may afterwards be set together again in their former postures, and will be as straight, sound, and good, as the first hour they were made; and being laid in oil and colour, according to your master Walton's direction, will last many years.

The length of your line, to a man that knows how to handle his rod, and to cast it, is no manner of incumbrance, excepting in woody places, and in landing of a fish, which every one that can afford to angle for pleasure, has somebody to do for him ; and the length of line is a mighty advantage to the fishing at a distance ; and to fish fine, and far off, is the first and principal rule for troutangling. $\dagger$

* Too long by one or two yards.-E.

t An artist may easily throw twelve yards of line with one hand; and with two, he may as easily throw eighteen.-H.

[An accomplished fly-flsher of the present day can throw his fly a distance of fifteen yards with a single-handed rod, and twenty-five and even thirty yards with the double-handed salmon-rod. Modern superiority in throwing the fly is the result of fishing with far better rods and lines than those used in the time of Sir John Hawkinsabout a century ago.-E.] 
Your line in this case should never be less, nor ever exceed two hairs next to the hook ; for one (though some, I know, will pretend to more art than their fellows) is indeed too few, the least accident, with the finest hand, being sufficient to break it : but he that cannot kill a trout of twenty inches long with two, in a river clear of wood and weeds, as this and some others of ours are, deserves not the name of an angler.

Now, to have your whole line as it ought to be, two of the first lengths nearest the hook should be of two hairs a-piece; the next three lengths above them of three; the next three above them of four; and, so of five, and six, and seven, to the very top : by which means, your rod and tackle will, in a manner, be taper from your very hand to your hook; your line will fall much better and straighter, and cast your fly to any certain place, to which the hand and eye shall direct it, with less weight and violence, that would otherwise circle the water, and fright away the fish.

In casting your line, do it always before you, and so that your fly may first fall upon the water, and as little of your line with it as is possible; though if the wind be stiff, you will then of necessity be compelled to drown a good part of your line to keep your fly in the water : and in casting your fly, you must aim at the further or nearer bank as the wind serves your turn, which also will be with and against you, on the same side, several times in an hour, as the river winds in its course, and you will be forced to angle up and down by turns accordingly, but endeavour, as much as you can, to have the wind, evermore, on your back. And always be sure to stand as far off the bank as your length will give you leave when you throw to the contrary side: though when the wind will not permit you so to do, and that you are constrained to angle on the same side whereon you stand, you must then stand on the very brink of the river, and cast your 
fly to the utmost length of your rod and line, up or down the river, as the gale serves.

It only remains, touching your line, to enquire whether your two hairs next to the hook are better twisted or open ? And for that I should declare that I think the open way the better, because it makes less show in the water, but that I have found an inconvenience, or two, or three, that have made me almost weary of that way; of which, one is, that, without dispute, they are not so strong open as twisted; another, that they are not easily to be fastened of so exact an equal length in the arming that the one will not cause the other to bag, by which means a man has but one hair upon the matter to trust to; and the last is that these loose flying hairs are not only more apt to catch upon every twig or bent they meet with, but moreover, the hook, in falling upon the water, will, very often, rebound and fly back betwixt the hairs, and there stick (which, in a rough water especially, is not presently to be discerned by the angler), so as the point of the hook shall stand reversed; by which means your fly swims backward, makes a much greater circle in the water, and till taken home to you and set right, will never raise any fish, or, if it should, I am sure, but by a very extraordinary chance, can hit none.*

Having done with both these ways of fishing at the top, the length of your rod, and line and all, I am next to teach you how to make a fly ; and afterwards of what dubbing you are to make the several flies I shall hereafter name to you.

In making a fly then, which is not a hackle or palmerfly (for of those, and their several kinds, we shall have occasion to speak every month in the year) you are first to hold your hook fast betwixt the fore-finger and thumb of your left-hand, with the back of the shank upwards, and

This cannot happen with the present gut casting-lines, the only sort that should be used for fly-fishing.-E. 
the point towards your fingers' ends; then take a strong small silk, of the colour of the fly you intend to make, wax it well with wax of the same colour too (to which end, you are always, by the way, to have wax of all colours about you) and draw it betwixt your finger and thumb, to the head of the shank, and then whip it twice or thrice about the bare hook, which you must know is done, both to prevent slipping, and also that the shank of the hook may not cut the hairs of your towght, which sometimes it will otherwise do: which being done, take your line, and draw it likewise betwixt your finger and thumb, holding the hook so fast as only to suffer it to pass by, until you have the knot of your towght almost to the middle of the shank of your hook, on the inside of it ; then whip your silk twice or thrice about both hook and line, as hard as the strength of the silk will permit; which being done, strip the feather for the wings proportionable to the bigness of your fly, placing that side downwards which grew uppermost before, upon the back of the hook, leaving so much only as to serve for the length of the wing of the point of the plume, lying reversed from the end of the shank upwards ; then whip your silk twice or thrice about the root-end of the feather, hook, and towght; which being done, clip off the root-end of the feather close by the arming, and then whip the silk fast and firm about the hook and towght, until you come to the bend of the hook, but not further, as you do at London, and so make a very unhandsome, and, in plain English, a very unnatural and shapeless fly; which being done, cut away the end of your towght, and fasten it, and then take your dubbing, which is to make the body of your fly, as much as you think convenient, and holding it lightly with your hook betwixt the finger and thumb of your left hand, take your silk with the right, and twisting it betwixt the finger and thumb of that hand, the dubbing will spin itself about the silk, which when it has done, whip it about the armed 
hook backward, till you come to the setting on of the wings; and then take the feather for the wings, and divide it equally into two parts, and turn them back towards the bend of the hook, the one on the one side and the other on the other of the shank, holding them fast in that posture betwixt the fore-finger and thumb of your left hand; which done, warp them so down as to stand, and slope towards the bend of the hook; and having warped up to the end of the shank, hold the fly fast betwixt the finger and thumb of your left hand, and then take the silk betwixt the finger and thumb of your right hand, and where the warping ends, pinch or nip it with your thumb-nail against your finger, and strip away the remainder of your dubbing from the silk, and then with the bare silk whip it once or twice about, make the wings to stand in due order, fasten, and cut it off ; after which with the point of a needle, raise up the dubbing gently from the warp, twitch off the superfluous hairs of your dubbing; leave the wings of an equal length, your fly will never else swim true, and the work is done. And this way of making a fly, which is certainly the best of all other, was taught me by a kinsman of mine, one Captain Henry Jackson, a near neighbour, an admirable flyangler, by many degrees the best fly-maker that ever I yet met with.* And now that I have told you how a fly is to be made, you shall presently see me make one, with which you may peradventure take a trout this morning, notwithstanding the unlikeliness of the day ; for it is now nine of the clock, and fish will begin to rise, if they will rise

* There needs nothing more be said of these directions, than that hundreds have, by means of them alone, become excellent fly-makers. $-\mathrm{H}$.

[Note.-I cannot agree with Sir J. Hawkins. Cotton's directions are limited to making the easiest of all made flies-a fly with body and wings, but without tail, hackle-feather for legs, tinsel for tip and ribbing. In consequence, I have given diagrams of the artificial fly in its several stages of fabrication, and have elucidated them with written descriptions and instructions. See the last pages of this work.-E.] 
to-day : I will walk along by you, and look on, and after dinner I will proceed in my lecture of fly-fishing.

VIat. I confess I long to be at the river, and yet I could sit here all day to hear you : but some of the one, and some of the other, will do well ; and I have a mighty ambition to take a trout in your River Dove.

Pisc. I warrant you shall: I would not for more than I will speak of but you should, seeing I have so extolled my river to you : nay, I will keep you here a month, but you shall have one good day of sport before you go.

VIat. You will find me, I doubt, too tractable that way ; for in good earnest, if business would give me leave, and that it were fit, I could find in my heart to stay with you for ever.

PIsc. I thank you, Sir, for that kind expression; and now let me look out my things to make this fly. 


\section{CHAPTER VI}

\section{[ฐecond פay]}

Pisc. Boy, come, give me my dubbing-bag here presently : and now, Sir, since I find you so honest a man, I will make no scruple to lay open my treasure before you.

Viat. Did ever any one see the like! What a heap of trumpery is here! Certainly never an angler in Europe has his shop half so well furnished as you have.

Pisc. You, perhaps, may think now, that I rake together this trumpery, as you call it, for show only; to the end that such as see it, which are not many I assure you, may think me a great master in the art of angling: but, let me tell you, here are some colours, as contemptible as they seem here, that are very hard to be got; and scarce any one of them which, if it should be lost, I should not miss, and be concerned about the loss of it too, once in the year. But look you, Sir, amongst all these I will choose out these two colours only, of which, this is bear's hair, this darker, no great matter what; but I am sure I have killed a great deal of fish with it; and with one or both of these you shall take trout or grayling this very day, notwithstanding all disadvantages, or my art shall fail me.

Viat. You promise comfortably, and I have a great deal of reason to believe everything you say; but I wish the fly were made, that we were at it.

PIsc. That will not be long in doing: and pray observe then. You see first how I hold my hook, and thus I begin. Look you, here are my first two or three whips about the bare hook; thus I join hook and line; 
thus I put on my wings; thus I twirl and lap on my dubbing; thus I work it up towards the head; thus I part my wings; thus I nip my superfluous dubbing from my silk ; thus fasten; thus trim and adjust my fly ; and there's a fly made; and now how do you like it ?

ViaT. In earnest, admirably well, and it resembles a fly : but we about London, make the bodies of our flies both much bigger and longer, so long as even almost to the very beard of the hook.

Pisc. I know it very well, and had one of those flies given me by an honest gentleman, who came with my father Walton to give me a visit; which (to tell you the truth) I hung in my parlour window to laugh at : but, Sir, you know the proverb, "They who go to Rome must do as they at Rome do;" and believe me, you must here make your flies after this fashion, or you will take no fish. Come, I will look you out a line, and you shall put it on, and try it. There, Sir, now I think you are fitted; and now beyond the farther end of the walk you shall begin: I see, at that bend of the water above, the air crisps the water a little : knit your line first here, and then go up thither, and see what you can do.

VIAT. Did you see that, Sir?

Pisc. Yes, I saw the fish : and he saw you too, which made him turn short. You must fish further off, if you intend to have any sport here ; this is no New River, let me tell you. That was a good trout, believe me: did you touch him?

VIAT. No, I would I had, we would not have parted so. Look you, there is another : this is an excellent fly. Pisc. That fiy I am sure would kill fish, if the day were right : but they only chew at it, I see, and will not take it. Come, Sir, let us return back to the fishinghouse : this still water, I see, will not do our business today : you shall now, if you please, make a fly yourself,*

* To make a fly is so essential, that he hardly deserves the name 
and try what you can do in the streams with that: and I know a trout taken with a fly of your own making, will please you better than twenty with one of mine. Give me that bag again, sirrah : look you, Sir, there is a hook, towght, silk, and a feather for the wings : be doing with those, and I will look you out a dubbing that I think will do.

VIAT. This is a very little hook.

Pisc. That may serve to inform you, that it is for a very little fly, and you must make your wings accordingly; for as the case stands, it must be a little fly, and a very little one too, that must do your business. Well said! believe me you shift your fingers very handsomely; I doubt I have taken upon me to teach my master. So, here's your dubbing now.

VIAT. This dubbing is very black.

Pisc. It appears so in hand; but step to the door, and hold it up betwixt your eye and the sun, and it will appear a shining red; let me tell you, never a man in England can discern the true colour of a dubbing, any way but that, and therefore chuse always to make your flies on such a bright sun-shine day as this, ${ }^{*}$ which also you may the better do, because it is worth nothing to fish in : here, put it on, and be sure to make the body of your fly

of an angler who cannot do it. There are many who will go to a tackle-shop, and tell the master of it, as Dapper does Subtle, in the Alchemist, that they want a fly ; for which they have a thing put into their hands, that would pose a naturalist to find a resemblance for ; though, when particular directions have been given, I have known them excellently made by the persons employed by the fishingtackle makers in London. But do thou, my honest friend, learn to make thy own flies; and be assured, that in collecting and arranging the materials, and imitating the various shapes and colours of these admirable creatures, there is little less pleasure than even in catching fish. - $\mathrm{H}$.

[NotE.-All this is changed now. The flies sold in the London tackle-shops are generally good, and in some vcry good.-E.]

* Excellent advice. The colour of feathers, fur, etc., cannot be accurately ascertained, except by looking through them at the light. In mixing differently coloured bits of dubbing a good light, natural or artificial, is necessary.-E. 
as tender as you can. Very good! upon my word you have made a marvellous handsome fly.

VIAT. I am very glad to hear it; it is the first that ever I made of this kind in my life.

Pisc. Away, away! you are a doctor at it; but I will not commend you too much, lest I make you proud. Come, put it on, and you shall now go downward to some streams betwixt the rocks below the little foot-bridge you see there, and try your fortune. Take heed of slipping into the water as you follow me under this rock : so, now you are over, and now throw in.

Viat. This is a fine stream indeed:-there's one! I have him.

Pisc. And a precious catch you have of him; pull him out! I see you have a tender hand: this is a diminutive gentleman, e'en throw him in again, and let him grow till he be more worthy your anger.*

VIAT. Pardon me, Sir, all's fish that come's to the hook with me now.-Another !

Pisc. And of the same standing.

Viat. I see I shall have good sport now: another! and a grayling. Why you have fish here at will.

Pisc. Come, come, cross the bridge, and go down the other side lower, where you will find finer streams and better sport, I hope, than this. Look you, Sir, here is a fine stream now, you have length enough, stand a little further off, let me entreat you, and do but fish this stream like an artist, and peradventure a good fish may fall to your share.-How now! what! is all gone?

VIAT. No, I but touch'd him; but that was a fish worth taking.

PIsc. Why now, let me tell you, you lost that fish by

* This passage proves Cotton to have been a real sportsman. He contemns catching small fish, and says, "throw them in again." Viator being a novice, sees no discredit in capturing " diminutive gentlemen," and it is quite in keeping with the sentiments of a young angler to exclaim, "All's fish that comes to the hook now."-E. 
your own fault, and through your own eagerness and haste ; for you are never to ofler to strike a good fish, if he do not strike himself, till first you see him turn his head after he has taken your fly, and then you can never strain your tackle in the striking, if you strike with any manner of moderation. Come, throw in once again, and fish me this stream by inches; for I assure you here are very good fish ; both trout and grayling lie here; and at that great stone on the other side, it is ten to one a good trout gives you the meeting.

VIAT. I have him now, but he is gone down towards the bottom: I cannot see what he is, yet he should be a good fish by his weight; but he makes no great stir.

Pisc. Why then, by what you say, I dare venture to assure you it is a grayling, who is one of the deadesthearted fishes in the world, and the bigger he is, the more easily taken. Look you, now you see him plain; I told you what he was: bring hither that landing-net, boy : and now, Sir, he is your own; and believe me a good one, sixteen inches long I warrant him : I have taken none such this year.

VIAT. I never saw a grayling before look so black.

Pisc. Did you not? Why then let me tell you, that you never saw one before in right season; for then a grayling is very black about his head, gills, and down his back; and has his belly of a dark gray, dappled with black spots, as you see this is; and I am apt to conclude that from thence he derives his name of umber. Though I must tell you this fish is past his prime, and begins to decline, and was in better season at Christmas than he is now. But move on; for it grows towards dinner time; and there is a very great and fine stream below, under that rock that fills the deepest pool in all the river, where you are almost sure of a good fish.

VIAT. Let him come, I'll try a fall with him. But I had thought that the grayling had been always in season 
with the trout, and had come in and gone out with him.

PIsc. Oh no! assure yourself a grayling is a winter fish; but such a one as would deceive any but such as know him very well indeed; for his flesh, even in his worst season, is so firm, and will so easily calver, that in plain truth he is very good meat at all times : but in his perfect season (which, by the way, none but an overgrown grayling will ever be), I think him so good a fish, as to be little inferior to the best trout that ever I tasted in my life.

VIAT. Here's another skipjack; and I have raised five or six more at least while you were speaking. Well, go thy way, little Dove ! thou art the finest river that ever I saw, and the fullest of fish. Indeed, Sir, I like it so well, that I am afraid you will be troubled with me once a year, so long as we two live.

PIsc. I am afraid I shall not, Sir : but were you once here a May or a June, if good sport would tempt you, I should then expect you would sometimes see me; for you would then say it were a fine river indeed, if you had once seen the sport at the height.

VIAT. Which I will do, if I live, and that you please to give me leave. There was one, and there another.

PIsc. And all this in a strange river, and with a fly of your own making! why what a dangerous man are you!

VIAT. I, Sir : but who taught me? and as Damrtas says by his man Dorus, so you may say by me,

If any man such praises have,

What then have I, that taught the knave ? *

But what have we got here ? a rock springing up in the middle of the river! this is one of the oddest sights that ever I saw.

PIsc. Why, Sir, from that pike $\dagger$ that you see

* Sidney's Arcadia.

$\dagger$ It is a rock, in the fashion of a spire-steeple, and almost as blg. 100-J 
standing up there distant from the rock, this is called Pike Pool. And young Mr. Izaak Walton was so pleased with it, as to draw it in landscape, in black and white, in a blank book I have at home, as he has done several prospects of my house also, which I keep for a memorial of his favour, and will shew you when we come up to dinner.

VIAT. Has young Master Izaak Walton been here too ?

Pisc. Yes, marry has he, Sir, and that again and again too, and in France since, and at Rome, and at Venice, and I can't tell where : but I intend to ask him a great many hard questions so soon as I can see him, which will be, God willing, next month. In the meantime, Sir, to come to this fine stream at the head of this great pool, you must venture over these slippery, cobbling stones; believe me, Sir, there you were nimble, or else you had been down; but now you are got over, look to yourself : for, on my word, if a fish rise here, he is like to be such a one as will endanger your tackle : how now !

VIAT. I think you have such command here over the fishes, that you can raise them by your word, as they say conjurers can do spirits, and afterward make them do what you bid them; for here's a trout has taken my fly, I had rather have lost a crown.* What luck's this ! he was a lovely fish, and turned up a side like a salmon.

It stands in the midst of the River Dove; and not far from Mr. Cotton's house; below which place this delicate river takes a swift career betwixt many mighty rocks, much higher and bigger than St. Paul's church before it was burnt. And this Dove bcing opposed by one of the highest of them, has, at last, forced itself a way through it; and after a mile's concealment, appears again with more glory and beauty than before that opposition, running through the most pleasant valleys and most fruitful meadows that this nation can justly boast of.-(WALTON, junior.)

* Not taken it in the ordinary angling acceptation, but taken it off the line-broken away with it, so that both fish and fly are lost. $-\mathrm{E}$. 
Pisc. O Sir, this is a war where you sometimes win, and must sometimes expect to lose. Never concern yourself for the loss of your fly, for ten to one I teach you to make a better. Who's that calls ?

SERv. Sir, will it please you to come to dinner ?

PIsc. We come. You hear, Sir, we are called, and now take your choice, whether you will climb this steep hill before you, from the top of which you will go directly into the house, or back again over these stepping-stones, and about by the bridge.

Viat. Nay, sure, the nearest way is best; at least my stomach tells me so ; and I am now so well acquainted with your rocks, that I fear them not.

PIsc. Come then, follow me; and so soon as we have dined, we will down again to the little house, where I will begin at the place I left off about fly-fishing, and read you another lecture; for I have a great deal more to say upon that subject.

VIAT. The more the better : I could never have met with a more obliging master, my first excepted; nor such sport can all the rivers about London ever afford, as is to be found in this pretty river.

PIsc. You deserve to have better, both because I see you are willing to take pains, and for liking this little so well; and better I hope to shew you before we part. 


\section{CHAPTER VII}

\section{[Iecono פay]}

Viat. Come, Sir, having now well dined, and being again set in your little house, I will now challenge your promise, and entreat you to proceed in your instruction for flyfishing; which that you may be the better encouraged to do, I will assure you that I have not lost, I think, one syllable of what you have told me; but very well retain all your directions, both for the rod, line, and making a fly, and now desire an account of the flies themselves.

Pisc. Why, Sir, I am ready to give it you, and shall have the whole afternoon to do it in, if nobody come in to interrupt us; for you must know (besides the unfitness of the day), that the afternoons, so early in March, signify very little to angling with a fly, though with a minnow, or a worm, something might (I confess) be done.

To begin, then, where I left off, my father Walton tells us of but twelve artificial flies only, to angle with at the top, and gives their names ; of which some are common with us here; and I think I guess at most of them by his description, and I believe they all breed and are taken in our rivers, though we do not make them either of the same dubbing or fashion. And it may be in the rivers about London, which I presume he has most frequented, and where it is likely he has done most execution, there is not much notice taken of many more: but we are acquainted with several others here, though perhaps I may reckon some of his by other names too; but if I do, I shall make you amends by an addition to his catalogue. And although the forenamed great master in 
the art of angling, for so in truth he is, tells you that no man should, in honesty, catch a trout till the middle of March, yet I hope he will give a man leave sooner to take a grayling, which, as I told you, is in the dead months in his best season: and do assure you (which I remember by a very remarkable token), I did once take upon the sixth day of December one, and only one, of the biggest graylings, and the best in season, that ever I yet saw or tasted; and do usually take trouts too, and with a fly, not only before the middle of this month, but almost every year in February, unless it be a very ill spring indeed; and have sometimes in January, so early as New-year's tide, and in frost and snow, taken grayling in a warm sunshine day for an hour or two about noon; and to fish for him with a grub, it is then the best time of all.

I shall therefore begin my fly-fishing with that month, though I confess very few begin so soon, and that such as are so fond of the sport as to embrace all opportunities, can rarely in that month find a day fit for their purpose; and tell you, that upon my knowledge these flies in a warm sun, for an hour or two in the day, are certainly taken.

\section{JANUARY}

1. A Red Brown, with wings of the male of a mallard almost white: the dubbing of the tail of a black longcoated cur, such as they commonly make muffs of ; for the hair on the tail of such a dog dies and turns to a red brown, but the hair of a smooth-coated dog of the same colour will not do, because it will not die, but retains its natural colour, and this fly is taken in a warm sun, this whole month through.

2. There is also a very little Bright DUN GNat, as little as can possibly be made, so little as never to be fished with, with above one hair next the hook; and 
this is to be made of a mixed dubbing of marten's fur, and the white of a hare's scut, with a very white and small wing; and it is no great matter how fine you fish, for nothing will rise in this month but a grayling; and of them I never, at this season, saw any taken with a fly, of above a foot long in my life: but of little ones about the bigness of a smelt, in a warm day, and a glowing sun, you may take enough with these two flies, and they are both taken the whole month through.

\section{FEBRUARY}

1. Where the red-brown of the last month ends, another almost of the same colour begins, with this saving, that the dubbing of this must be of something a blacker colour, and both of them wrapt on with red silk. The dubbing that should make this fly, and that is the truest colour, is to be got off the black spot of a hog's ear: not that a black spot in any part of the hog will not afford the same colour, but that the hair in that place is, by many degrees, softer, and more fit for the purpose. His wing must be as the other [1. in January]; and this kills all this month, and is called the lesser red-brown.

2. This month, also, a plain hackle, or palmer-fly, made with a rough black body, either of black spaniel's fur, or the whirl of an ostrich feather, and the red hackle of a capon over all, will kill, and, if the weather be right, make very good sport.

3. Also a lesser hackle, with a black body, also silver twist over that, and a red feather over all, will fill your pannier, if the month be open, and not bound up in ice and snow, with very good fish; but, in case of a frost and snow, you are to angle only with the smallest gnats, browns, and duns you can make; and with those are only to expect graylings no bigger than sprats.

4. In this month, upon a whirling round water, we 
have a great hackle, the body black, and wrapped with a red feather of a capon untrimmed; that is, the whole length of the hackle staring out (for we sometimes barb the hackle-feather short all over; sometimes barb it only a little, and sometimes barb it close underneath), leaving the whole length of the feather on the top or back of the fly, which makes it swim better, and, as occasion serves, kills very great fish.

5. We make use also, in this month, of another great hackle, the body black, and ribbed over with gold twist, and a red feather over all; which also does great execution.

6. Also a great dun, made with dun bear's hair, and the wings of the gray feather of a mallard near unto his tail ; which is absolutely the best fly can be thrown upon a river this month, and with which an Angler shall have admirable sport.

7. We have also this month the great blue dun, the dubbing of the bottom of bear's hair next to the roots, mixed with a little blue camlet, the wings of the dark gray feather of a mallard.

8. We have also this month a dark-brown, the dubbing of the brown hair off the flank of a brended cow, and the wings of the gray drake's feather.

And note, that these several hackles, or palmer-flies, are some for one water and one sky, and some for another ; and, according to the change of those, we alter their size and colour; and note also, that both in this, and all other months of the year, when you do not certainly know what fly is taken, or cannot see any fish to rise, you are then to put on a small hackle, if the water be clear, or a bigger, if something dark, until you have taken one; and then thrusting your finger through his gills, to pull out his gorge, which being opened with your knife, you will then discover what fly is taken, and may fit yourself accordingly. 
For the making of a hackle, or palmer-fly, my father Walton has already given you sufficient direction.*

[I am not very favourable to simple hackles, or to any sort of palmers, either in this month, or in March. I would not use palmers until April. Indeed, I consider them summer and autumn baits. They are representations of caterpillars, produced in warm weather, and very rarely found in this climate of ours in April. Cotton gives a list of eight flies for February. I do not like any one of them. I will give four patterns for this month, confident of their attractiveness.

No. 1. Wings, a light brown, mottled feather of the mallard, found under its wing; body, a mixture of red squirrel's fur and claret mohair, warped up the hook to the wings with fiery-brown silk; legs, a hackle dyed claret. Hooks, 8, 9, 10.

No. 2. Wings, standing upright, of a starling's wingfeather ; tail, two fibres of the mottler mallard's feather ; body, dark olive mohair, tipped with silver tinsel. Hooks, 9 and 10. A good fly on a bright day.

No. 3. Wings, reddest feather of the woodcock's wing; body, dark fur of the hare's ear, to be picked out at the shoulder; gold tip, and tail two fibres of the mallard feather. Hooks, same size as those of No. 2.

No. 4. Wings and legs, brown mottled partridge backfeather; body, a mixture of orange mohair, and dark and light hare's ear fur. Hooks, 10 and 11.-E.]

\section{MARCH}

For this month you are to use all the same hackles and flies with the other; but you are to make them less.

* But, with Mr. Cotton's good leave, he has not, nor any author that $I$ know of, unless we are to take that for a palmer, which Walton has given directions for making, page 110 , which I can never do till I see. what I have never yet seen, viz., caterpillars with wings. Rejecting, therefore, wings as unnatural and absurd; supposing you would make the plain hackle or palmer, which are terms of the same import, the method of doing it is as follows:- So far, Sir John Hawkins. But I reject his instructions for making a hackle, and substitute my own. They will be found in the Appendix to this work, following the plate on which are engraved diagrams of winged flies and hackle in their first, middle, and last stages of manufacture.-E. 
1. We have, besides, for this month, a little dun, called a whirling dun (though it is not the whirling dun indeed, which is one of the best flies we have); and for this, the dubbing must be of the bottom fur of a squirrel's tail; and the wing, of the gray feather of a drake.

2. Also a bright brown; the dubbing either of the brown of a spaniel, or that of a red cow's flank, with a gray wing.

3. Also a whitish dun ; made of the roots of camel's hair ; and the wings, of the gray feather of a mallard.

4. There is also for this month a fly called the thorntree fly; the dubbing, an absolute black, mixed with eight or ten hairs of Isabella-coloured mohair; the body as little as can be made; of a bright mallard's feather. An admirable fly, and in great repute amongst us for a killer.

5. There is, besides this, another BluE Dun, the dubbing of which it is made being thus to be got. Take a small-tooth comb, and with it comb the neck of a black greyhound, and the down that sticks in the teeth will be the finest blue that ever you saw. The wings of this fly can hardly be too white, and he is taken about the tenth of this month, and lasteth till the four and twentieth.

6. From the tenth of this month also, till towards the end, is taken a little Black GNaT; the dubbing either of the fur of a black water-dog, or the down of a young black water-coot, the wings of the male of a mallard as white as may be, the body as little as you can possibly make it, and the wings as short as his body.

7. From the sixteenth of this month also to the end of it, we use a Bright Brown; the dubbing for which is to be had out of a skinner's lime-pits, and of the hair of an abortive calf, which the lime will turn to be so bright as to shine like gold: for the wings of this fly, 
the feather of a brown hen is best, which fly is taken till the tenth of April.

[Trout take flies eagerly this month, chiefly in sharp, gravelly, somewhat shallow streams. On their bottoms they lie to clean themselves by friction against sand and gravel, to feed on small fish, etc., and to enjoy the watery element, more oxygenated than deep pools, by the action of a spring-tide sun's rays. The best flies for this month are,-

No. 1. Hofland's Fancy.-Wings, woodcock's wingfeather; legs, bright red cock's hackle; body, dark, brown-red floss silk; tail, two fibres of the red hackle. Hook, No. 10. This is a standard fly for all the trout streams of the metropolitan counties.

No. 2. The Red Spinner.-Wings, light brown mallard; body, scarlet mohair, ribbed with thin gold wire; legs, blood-red hackle; tail, two fibres of the same. Hooks, 9 and 10.

No. 3. Wings, a field-fare's wing-feather ; body, orangecoloured floss silk, over which, in close, regular laps from tail to shoulder, a furnace-hackle, that is a cock's neckfeather, the outer part of the fibres of which are of a pure dark red, the inner part, next the stem of the feather, being quite black. It is a most valuable feather. Hook, No. 10. An excellent general fly.

No. 4. Wings, hen pheasant's wing-feather; legs, a dun hackle, with dark bars; body, light-blue fur of the water-rat, mixed with yellow mohair; tail, two fibres of the hackle used for legs. Hook, 10.

No. 5. СосH-Y-BoNdDHu.-Wings, a furnace-hackle, tied buzz; legs, the same feather; body short, of black ostrich and bright bronze peacock harl, twisted together; gold tip ; and hooks 10 and 11.

No. 6. The March-Brown.-Wings, standing erect, of the hen pheasant's wing or tail-feather; body, pale orange mohair mixed with reddish fur from the hare's poll ; legs, a pure honey-dun hackle ; tail, two fibres of the pheasant's wing. Hooks, 7, 8, 9, and 10.

I consider this the best of all flies from the middle of March to the end of April, with the exception of the oakfly for the latter month. When the natural fly is on the water in great abundance, it is taken by trout as eagerly 
as the May-fly, or green drake, in May and June. I esteem it so highly, that I will give two other ways of dressing it.

1st. BLACKER's WAY.-Wings, hen pheasant's wingfeather or gray mottled partridge feather; body, light and dark hare's-ear fur, mixed with a little dark yellow mohair, and ribbed with pale yellow silk; legs, small brown partridge back-feather; tail, two fibres of brown mottled mallard's feather. Hooks, 9 and 10.

2nd. Blaine's way. - Wings, mottled feather from the tail of a partridge, or hen pheasant, set upright; body, light fur and red squirrel's fur mixed, and ribbed with yellow silk; legs, a grizzled dun-hackle, and tail whisks of two fibres of the feather the wings are made of. Hook, No. 6.

When the natural fly was well out upon the water, and trout taking it eagerly, I would fish with three of the above patterns-one of each on the casting-line at the same time, using the largest for stretcher.-E.]

\section{APRIL}

All the same hackles and flies that were taken in March will be taken in this month also, with this distinction only concerning the flies, that all the browns be lapped with red silk, and the duns with yellow.

1. To these a small Bright Brown, made of spaniel's fur, with a light gray wing, in a bright day, and a clear water, is very well taken.

2. We have too a little DARK Brown, the dubbing of that colour, and some violet camlet mixed, and the wing, of the gray feather of a mallard.

3. From the sixth of this month to the tenth, we have also a fly called the VioLET-FLY, made of a dark violet stuff, with the wings of the gray feather of a mallard.

4. About the twelfth of this month comes in the fly called the WhirLiNG DuN, which is taken every day, about the mid-time of day, all this month through, and, by fits, from thence to the end of June, and is commonly made of the down of the fox-cub, which is of an ash colour at the roots next the skin, and ribbed about with 
yellow silk; the wings, of the pale gray feather of a mallard.

5. There is also a Yellow Dun, the dubbing of camel's hair, and yellow camlet or wool, mixed, and a white-gray wing.

6. There is also this month another LitTle Brows, besides that mentioned before, made with a very slender body, the dubbing of dark brown and violet camlet, mixed, and a gray wing, which, though the direction for the making be near the other, is yet another fly, and will take when the other will not, especially in a bright day and a clear water.

7. About the twentieth of this month comes in a fly called Horse-flesh Fly; the dubbing of which is a blue mohair, with pink-coloured and red tammy mixed, a light coloured wing, and a dark brown head. This fly is taken best in an evening, and kills from two hours before sunset till twilight, and is taken the month through.

[The above is not a bad list of flies for April-the best month in the year for fly-fishing-I mean for catching the largest number of trout, but by no means the largest in size, and still less the highest in condition. Trout, in English rivers, are not in full season until after they have fed and fattened on the May-fly-say, from the 15th of June to the 15th of August.

The list of flies I have written for March will kill in April. Add to them the following more appropriate ones :-

No. 1. The OAK-FLY. - Wings, to lie flat, of the wingfeather of a young partridge or hen pheasant; body, yellow mohair, ribbed with dark brown silk; legs, a honey-dun hackle, lapped round thrice at the shoulder; tip, pale gold twist. Hooks, 9 and 10 . This is a favourite fly of mine. In April I never fish without trying it.

No. 2. The Stone-Fly. - Wings, hen pheasant's tailfeather, dressed long, and flat and full; body, large and long, of a mixture of light hare's-ear fur and yellow-brown mohair, ribbed with yellow silk ; legs, a brown-red hackle ; and tail, two fibres of brown mallard. Hooks, 6, 7, and 
8. The fur near the tail should have more yellow in it than the middle or upper part of the body. A good spring-fly in small, deep, thickly wooded streams. Its reputation is greater than it deserves.

No. 3. Carshalton Cock-tall.-Wings, light fibres, standing erect, of the hen starling's wing-feather; body, light blue dun fur, taper and thin, and ribbed with yellow silk ; legs, three laps of a small, pale dun-hackle ; tail, two fibres of the same. Hooks, 11 and 12. A capital general fly at low water.

No. 4. Alder-Fly.-Wings, flat and two sets; lower, starling's wing-feather; upper, either landrail's wing, partridge red tail-feather, or hen pheasant's ditto ; body, either bronze-coloured floss silk, or bronze peacock harl, to be dressed full and tapering; legs, black hackle; tail, two flbres of the same. Hooks, 9 and 10.

No. 5. SAND-FLY.-Wings, sandy-coloured landrail's wing-feather; body, a mixture of brown fur from the hare's poll and orange mohair; ginger hackle for legs. Hooks, 8, 9, 10.

No. 6. Wings, light gray mottled mallard feather; body, blue mole's fur, over which, at shoulder, blood-red hackle ; tail, two fibres of the mallard feather. Hooks, 9 and 10. This is a very good fly, and will also kill well with a brown-red mohair body.

The artificial baits, called palmers, are imitations of caterpillars of various sizes and colours. They answer best in deep and somewhat sluggish streams with banks densely wooded. I have but a poor opinion of them in rapid, clear streams, particularly mountainous ones. The following are the best:-

Black Palmer.-Body, black ostrich harl, ribbed with gold twist and black cock's long-fibred hackle. Hooks, from 4 to 8 .

Brown Palmer.-Body, amber-brown mohair, ribbed with gold and silver twist, by which, from tail to head, a brown-red cock's hackle. Hook as before.

ReD PALMER.-Body, deep red mohair, ribbed with gold twist, by which is to be wound a blood-red hackle. Hook as before.

Peacock Palmer.-Body, a brilliant bronze and azure full-fibred peacock harl, ribbed closely with silver tinsel, by which a dark grizzled hackle; head, of red mohair; 
tying silk, red. Hook as before. If dressed full, and an inch in length, it will lure large Thames trout and chub.- E.]

\section{MAY}

And now, sir, that we are entering into the month of May, I think it requisite to beg not only your attention, but also your best patience; for I must now be a little tedious with you, and dwell upon this month longer than ordinary; which, that you may the better endure, I must tell you, this month deserves and requires to be insisted on; forasmuch as it alone, and the next following, afford more pleasure to the fly-angler than all the rest: and here it is, that you are to expect an account of the green-drake, and stone-fly, promised you so long ago, and some others that are peculiar to this month, and part of the month following; and that, though not so great either in bulk or name, do yet stand in competition with the two before-named; and so, that it is yet undecided amongst the anglers, to which of the pretenders to the title of the MAY-FLY, it does properly and duly belong;* neither dare I, where so many of the learned in this art of angling are got in dispute about the controversy, take upon me to determine; but I think I ought to have a vote amongst them, and according to that privilege, shall give you my free opinion; and peradventure when I have told you all, you may incline to think me in the right.

ViaT. I have so great a deference to your judgment in these matters, that I must always be of your opinion ; and the more you speak, the faster I grow to my attention, for I can never be weary of hearing you upon this subject.

Pisc. Why that's encouragement enough; and now prepare yourself for a tedious lecture; but I will first

* To the Ephemera vulgata, now commonly called the May-fly, and green drake.-E. 
begin with the flies of less esteem, thougl almost anything will take a trout in May, that I may afterwards insist the longer upon those of greater note and reputation; know therefore, that the first fly we take notice of in this month, is called

1. The Turkey-FLy, the dubbing ravelled out of some blue stuff, and lapt about with yellow silk; the wings, of a gray mallard's feather.

2. Next, a Great Hackle or Palmer-Fly, with a yellow body ribbed with gold-twist, and large wings, of a mallard's feather dyed yellow, with a red capon's hackle over all.

3. Then a BLACK FLY, the dubbing of a black spaniel's fur; and the wings, of a gray mallard's feather.

4. After that, a Light Brown with a slender body, the dubbing twirled upon small red silk, and raised with the point of a needle, that the ribs or rows of silk may appear through; the wings of the gray feather of the mallard.

5. Next, a Litrle Dun, the dubbing of a bear's dun whirled upon yellow silk; the wings, of the gray feather of a mallard.

6. Then, a White Gnat, with a pale wing, and a black head.

7. There is also in this month, a fly called the PEACOCK-FLy : the body made of a whirl of a peacock's feather, with a red head; and wings, of a mallard's feather.

8. We have then another very killing $n y$, known by the name of the DuN-cuT ; the dubbing of which, is a bear's dun, with a little blue and yellow mixed with it; a large dun wing, and two horns at the head, made of the hairs of a squirrel's tail.

9. The next, is a Cow-LAdy, a little fly; the body, of a peacock's feather; the wing, of a red feather, or strips of the red hackle of a cock. 
10. We have then, the Cow-DUNG-FLY; the dubbing, light brown and yellow mixed; the wing, the dark gray feather of a mallard. And note, that besides these above mentioned, all the same hackles and flies, the hackles only brighter, and the flies smaller, that are taken in April, will also be taken this month, as all browns and duns : and now I come to my STONE-FLy and GREeNDRAKE, which are the matadores for trout and grayling, and in their season kill more fish in our Derbyshire rivers, than all the rest, past and to come, in the whole year besides.

But first I am to tell you, that we have four several flies which contend for the title of the May-fly ; namely,-

The Green-Drake.

The STONE-FLY.

The BLACK-FLY, and

The little yellow MAY-FLY.

And all these have their champions and advocates to dispute and plead their priority; though I do not understand why the two last-named should; the first two having so manifestly the advantage, both in their beauty, and the wonderful execution they do in their season.

11. Of these the GreEN-DRAKE comes in about the twentieth of this month, or betwixt that and the latter end; for they are sometimes sooner, and sometimes later, according to the quality of the year; but never well taken till towards the end of this month, and the beginning of June. The Stone-FLy comes much sooner, so early as the middle of April ; but is never well taken till towards the middle of May, and continues to kill much longer than the GREEN-DRAKE stays, with us, so long as to the end almost of June; and indeed, so long as there are any of them to be seen upon the water; and sometimes in an artificial fly, and late at night, or before sumrise in a morning, longer. 
Now both these flies, and I believe many others, though I think not all, are-certainly and demonstratively bred in the very rivers where they are taken: our cadis or cod-bait which lie under stones in the bottom of the water, most of them turning into those two flies, and being gathered in the husk, or crust, near the time of their maturity, are very easily known and distinguished, and are of all other, the most remarkable, both for their size, as being of all other the biggest, the shortest of them being a full inch long or more; and for the execution they do, the trout and grayling being much more greedy of them than of any others; and indeed the trout never feeds fat, nor comes into his perfect season, till these flies come in.

Of these the GreEN-Drake never discloses from his husk, till he be first there grown to full maturity, body, wings, and all ; and then he creeps out of his cell, but with his wings so crimpt and ruffled, by being prest together in that narrow room, that they are, for some hours totally useless to him; by which means he is compelled either to creep upon the flags, sedges, and blades of grass, if his first rising from the bottom of the water be near the banks of the river, till the air and sun stiffen and smooth them : or, if his first appearance above water happen to be in the middle, he then lies upon the surface of the water like a ship at hull; for his feet are totally useless to him there, and he cannot creep upon the water as the STONE-FLy can, until his wings have got stiffness to fly with (if by some trout or grayling he be not taken in the interim, which ten to one he is), and then his wings stand high, and closed exact upon his back, like the butterfly, and his motion in flying is the same. His body is, in some, of a paler, in others, of a darker yellow ; for they are not all exactly of a colour, ribbed with rows of green, long, slender, and growing sharp towards the tail, at the end of which he has threc 
long small whisks of a very dark colour, almost black, and his tail turns up towards his back like a mallard; from whence, questionless, he has his name of the GreENDRAKE. These, as I think I told you before, we commonly dape, or dibble with, and having gathered great store of them into a long draw-box, with holes in the cover to give them air (where also they will continue fresh and vigorous a night or more) we take them out thence by the wings, and bait them thus upon the hook. We first take one (for we commonly fish with two of them at a time), and putting the point of the hook into the thickest part of his body, under one of his wings, run it directly through, and out at the other side, leaving him spitted cross upon the hook; and then taking the other, put him on after the same manner, but with his head the contrary way; in which posture they will live upon the hook, and play with their wings, for a quarter of an hour or more; but you must have a care to keep their wings dry, both from the water, and also that your fingers be not wet when you take them out to bait them, for then your bait is spoiled.*

* The two preceding paragraphs are worthy of Cotton's reputation. They contain a good description of the natural May-fly, or Green Drake, and teach how that fly is to be angled with in a live state. His method of making it artificially is not the best, in my judgment. I have written fully, carefully, and, I think, as accurately as may be, of the May-fly in A Handbook of Angling, saying of it, - "This famous fly is the opprobrium of fly-makers. Try how they will, they cannot, in my opinion, imitate it well. The wings are their greatest foil. In making the body, they succeed tolerably well. Still, the best imitation is defective, and, except upon certain occasions, the artificial May-1ly is not a deadly bait. The natural fly used in dibbing, far surpasses it. However, the imitation, faulty as it is, will kill when the natural fly is scarce on the water, as in cold, dark, windy days. The artificial fly answers best in currents, and in pools or deeps that are moved to small waves by a bluif south or west wind. The general feather used for the wings of this fly is a dappled one, found on the sides under the wings of the mallard, and dyed a pale yellow-green colour. To hit the true colour is the great difficulty. How to get over it, I know not. I must be content to cite the best authorities. First, I will take Mr. Blacker, a capital judge of colours, who dyes his feathers yellow by the following recipe :-Boil two or three handfuls of yellow wood one hour in a 
Having now told you how to angle with this fly alive, I am now to tell you next how to make an artificial fly, that will so perfectly resemble him, as to be taken in a rough windy day, when no flies can lie upon the water, nor are to be found about the banks and sides of the river, to a wonder; and with which, you shall certainly kill the best trout and grayling in the river.

The artificial GreEn-Drake then, is made upon a large hook, the dubbing, camel's hair, bright bear's hair, the soft down that is combed from a hog's bristles, and yellow camlet, well mixed together; the body long, and ribbed about with green silk, or rather yellow, waxed with green wax: the whisks of the tail, of the

quart of soft water; wash the mallard feathers with soap and warm water; then boil them a short time, with a large spoonful of alum and tartar, in a little pipkin holding a pint of water; take them out, and immerse them in your yellow decoction, and simmer slowly for an hour or two. The shorter the simmering, the paler the yellow of the feathers; take them out and wash them in clean hard water. When there is occasion for dyeing yellow-green, add a little blue, more or less, according to the shade of green you wish to give the yellow. Mr. Ronald's Fly-fisher's Enlomology, recommends another way for dyeing mallard's feathers for the May-fly's wings. He tells us to make a mordant, by dissolving a quarter of an ounce of alum in a pint of water, and then to slightly boil the feathers in it to get the grease out of them, after which to boil them in an infusion of fustic to procure a yellow, and then subduing the brightness of the yellow by adding a little copperas to the infusion. Having now the wing-feathers dyed, I'll tell you how to make the fly:-Body, bright yellow mohair, or floss silk, ribbed sparingly with a very thin, light bronze peacock's harl; wings, mottled feather of the mallard, dyed a pale yellow-green. They are to stand erect, and be slightly divided; legs, a couple of turns, close under the wings, of a light red ginger hackle; tail-whisks, three black hairs from a rabbit's whisker. Hooks, 6, 7, and 8. Another way,-Body, yellow-green mohair ; wings, mallard's feather dyed yellow ; a black head ; legs, a yellowish hackle; tail, three hairs from a black bear's skin. A third way,-Body, yellow floss silk, ribbed with brown tying silk; wings, as before ; legs, a yellow, grizzled dun hackle ; tail, as bcfore ; head, bronze peacock harl; and hooks as beforc. During the season of the May-fly, I would angle with three flies of different sizes and colours. I should then have three chances of success, and could ascertain whicl was the preferable fly." I think the May-fly of Ireland is of greener hue than in England. In small, well wooded rivers of mild temperature, the May-fly grows to a larger size than in exposed, wide rivers in our colder counties.-E. 
long hairs of sables, or fitchet, and the wings, of a whitegray feather of a mallard, dyed yellow, which also is to be dyed thus :

Take the root of a barbary tree, and shave it, and put to it woody viss, with as much alum as a walnut, and boil your feathers in it with rain-water; and they will be of a very fine yellow.

I have now done with the Green-drake, excepting to tell you, that he is taken at all hours during his season, whilst there is any day upon the sky; and with a madefly I once took, ten days after he was absolutely gone, in a cloudy day, after a shower, and in a whistling wind, five-and-thirty very great trouts and graylings, betwixt five and eight of the clock in the evening, and had no less than five or six flies, with three good hairs a-piece, taken from me in despite of my heart, besides.

12. I should now come next to the Stone-fly, but there is another gentleman in my way, that must of necessity come in between, and that is the GraY-Drake, which in all shapes and dimensions is perfectly the same with the other, but quite almost of another colour, being of a paler, and more livid yellow, and green, and ribbed with black quite down his body, with black shining wings, and so diaphanous and tender, cobweb-like, that they are of no manner of use for daping; but come in, and are taken after the Green-drake, and in an artificial fly kill very well; which fly is thus made, the dubbing of the down of a hog's bristles, and black spaniel's fur, mixed, and ribbed down the body with black silk, the whisks of the hairs of the beard of a black cat, and the wings of the black gray feather of a mallard.

And now I come to the STONE-FLY; but am afraid I have already wearied your patience; which if I have, I beseech you freely tell me so, and I will defer the remaining instructions for fly-angling till some other time.

Viat. No, truly, Sir, I can never be weary of hearing 
you. But if you think fit, because I am afraid I am too troublesome, to refresh yourself with a glass and a pipe, you may afterwards proceed, and I shall be exceedingly pleased to hear you.

Pisc. I thank you, Sir, for that motion : for, believe me, I am dry with talking: here, boy! give us here a bottle and a glass; and, Sir, my service to you, and to all our friends in the south.

ViaT. Your servant, Sir; and I'll pledge you as heartily; for the good powdered beef I eat at dinner, or something else, has made me thirsty.

[To Mr. Cotton's list of flies for May, add the following :-

No. 1. Body, gold-coloured floss silk; wings and legs, light brown grouse hackle, from the neck of the bird. Hook, 10. This is the grouse hackle, and is a good summer fly at low water.

No. 2. Body, same as before; wings, gray mottled partridge tail-feather; legs, wren's tail-feather; tail, two small fibres of brown mallard. This fly should be dressed small and fine, and the body may be varied with orange ; and for the Irish rivers, with green floss silk. It is an excellent summer fly, and good for grayling in autumn.

No. 3. Wings short, and to stand erect, of the yellow feather found under the wings of the thrush and red-start; body, light buff fur; legs, a very short fibred yellow-dun hackle ; tail, two fibres of the same. Hooks, 12 and 13. This is the little May-fly, Yellow Sally, or Castle-fly. It appears a week or ten days earlier in May than the Greendrake, and kills well of mornings and evenings.

No. 4. Blue-Bottle.-Wings, starling's clear wingfeather, to lie flat; body, stone-blue floss silk, to be thick and short, and tipped with gold tinsel ; black hackle under shoulder for legs. Hooks, 8, 9, and 10. Trout take it frecly on fine evenings, as a sort of dessert after a full dinner on the Green-drake. It is a good summer fly for chub.

No. 5. The WAsp-Fly.-Wings, hen pheasant's wingfeather; body, light orange mohair, wound in separate circles from tail to shoulder, between circles, a ribbing of black ostrich harl; legs, three turns at shoulder of a 
light brown-red hackle; head, bronze peacock harl. Hooks, 6, 7, 8. A capital fly for large trout in deep currents, or in pools ruffled by the wind.

For very fine May evenings, and for those of the summer and early autumn months, there are three standard flies, called "owl-flies," from their wings, I suppose, being made of the feathers of different coloured owls.

The first, which should be used early in the evening, has its body of any soft brown fur; two sets of wings; under ones, of the soft feather of a brown owl ; and upper ones, of a dark brown mottled mallard feather; legs, a long-fibred ginger hackle, lapped behind the wings to make neck and head. Hooks, 5 to 8 .

The second, to be used during twilight, has a body made of cream-colour fur, and its wings of soft owl feather of the same colour; ginger hackle under and behind wings. Hook, as before.

The third, fit for angling at night, is made of white ostrich harl, dressed full ; wings, of the feather of a nearly white owl; legs, white hen's hackle; and brown head. Hook, as before.-E.] 


\section{CHAPTER VIII}

\section{[ฐccono Day]}

Viat. So, Sir, I am now ready for another lesson, so soon as you please to give it me.

Pisc. And I, Sir, as ready to give you the best I can. Having told you the time of the STONE-FLY's coming in, and that he is bred of a cadis in the very river where he is taken, I am next to tell you that,

13. This same Stone-Fly has not the patience to continue in his crust, or husk, till his wings be full grown; but so soon as ever they begin to put out, that he feels himself strong (at which time we call him a jack), squeezes himself out of prison, and crawls to the top of some stone, where if he can find a chink that will receive him, or can creep betwixt two stones, the one lying hollow upon the other, which, by the way, we also lay so purposely to find them, he there lurks till his wings be full grown, and there is your only place to find him, and from thence doubtless he derives his name; though, for want of such convenience, he will make shift with the hollow of a bank, or any other place where the wind cannot come to fetch him off. His body is long, and pretty thick, and as broad at the tail almost as in the middle; his colour a very fine brown, ribbed with yellow, and much yellower on the belly than the back; he has two or three whisks also at the tag of his tail, and two little horns upon his head; his wings, when full grown, are double, and flat down his back, of the same colour, but rather darker than his body, and longer than it, though he makes but little use of them; for you shall rarely see him flying, though often swimming 
and paddling with several feet he has under his belly, upon the water, without stirring a wing: but the Drake will mount steeple-high into the air, though he is to be found upon flags and grass too, and indeed everywhere high and low, near the river ; there being so many of them in their season, as were they not a very inoffensive insect, would look like a plague; and these drakes, since I forgot to tell you before, I will tell you here, are taken by the fish to that incredible degree, that, upon a calm day, you shall see the still deeps continually all over circles by the fishes rising, who will gorge themselves with those flies, till they purge again out of their gills; and the trouts are at that time so lusty and strong, that one of eight or ten inches long, will then more struggle, and tug, and more endanger your tackle, than one twice as big in winter ; but pardon this digression.

This Stone-Fly then, we dape or dibble with, as with the Drake, but with this difference, that whereas the GREEN-DRAKE is common both to stream and still, and to all hours of the day, we seldom dape with this but in the streams (for in a whistling wind a made-fly in the deep, is better), and rarely, but early and late, it not being so proper for the mid-time of the day ; though a great grayling will then take it very well in a sharp stream, and here and there, a trout too, but much better toward eight, nine, ten, or eleven of the clock at night, at which time also the best fish rise, and the later the better, provided you can see your fly ; and when you cannot, a made-fly will murder, which is to be made thus : the dubbing, of bear's dun, with a little brown and yellow camlet very well mixed, but so placed that your fly may be more yellow on the belly and towards the tail, underneath, than in any other part; and you are to place two or three hairs of a black cat's beard on the top of the hook, in your arming, so as to be turned up when you warp on your dubbing, and to stand almost upright, and staring one from another; 
and note, that your fly is to be ribbed with yellow silk; and the wings long, and very large, of the dark gray feather of a mallard.

14. The next May-fly is the BLACK-FLY; made with a black body, of the whirl of an ostrich-feather, ribbed with silver-twist, and the black hackle of a cock over all ; and is a killing fly, but not to be named with either of the other.

15. The last May-fly (that is of the four pretenders), is the little Yellow MAY-FLY; in shape exactly the same with the Green-Drake, but a very little one, and of as bright a yellow as can be seen : which is made of a bright yellow camlet, and the wings of a white-gray feather dyed yellow.

16. The last fly for this month (and which continues all June, though it comes in the middle of May), is the fly called the CAMLET-FLY, in shape like a moth, with fine diapered or water wings, and with which as I told you before, I sometimes used to dibble; and grayling will rise mightily at it. But the artificial fly,-which is only in use amongst our anglers, - is made of a dark brown shining camlet, ribbed over with a very small light green silk, the wings of the double gray feather of a mallard; and it is a killing fly for small fish ; and so much for May.

\section{JUNE}

From the first to the four and twentieth, the GreenDRAKE and STONE-FLY are taken, as I told you before.

1. From the twelfth to the four and twentieth late at night, is taken a fly, called the OwL-FLy, the dubbing of a white weasel's tail, and a white gray wing.*

2. We have then another dun, called the BARM-FLY, from its yeasty colour, the dubbing of the fur of a yellowdun cat, and a gray wing of a mallard's feather.

* This artificial white moth will be taken at night during June, July, and August.-E. 
3. We have also a HACKLE with a purple body, whipt about with a red capon's feather.

4. As also a Gold-Twist Hackle with a purple body, whipt about with a red capon's feather.

5. To these we have this month a FLEsh-FLY, the dubbing of a black spaniel's fur, and blue wool mixed, and a gray wing.

6. Also another little flesh-fly, the body made of the whirl of a peacock's feather, and the wings of the gray feather of a drake.

7. We have then the PEACOCK-FLY, the body and wing both made of the feather of that bird.

8. There is also the flying-ant or ANT-FLY, the dubbing of brown and red camlet mixed, with a light gray wing.

9. We have likewise a Brown GNaT, with a very slender body of brown and violet camlet well mixed, and a light gray wing.

10. And another little Black Gnat, the dubbing of black mohair, and a white gray wing.

11. As also a Green Grasshopper; the dubbing of green and yellow wool mixed, ribbed over with green silk, and a red capon's feather over all.

12. And, lastly, a little Dun Grasshopper; the body slender, made of a dun camlet and a dun hackle at the top.

[Nearly all the flies I have described for May will kill in June, for which the three following are appropriate :-

No. 1. Dark Mackerel.-Wings, dark-brown mottled mallard feather; body, deep mulberry-coloured floss silk, ribbed with gold tin iel; legs, purple hackle; tail, three black rabbit's whiskers. Hooks, 9 and 10.

No. 2. OrL-FLY. - Wings, reddest fibres of landrail, to lie flat and long; body, an alternate ribbing of dark brown and orange mohair; horns, two brown hackle fibres. Hooks, 8 and 9.

No. 3. Wings and legs, a very small dun hackle, wound over a body made of a mixture of blue-dun and orange- 
coloured mohair. Hooks, 11 and 12. A general killer in low, clear water in summer and autumn.-E.]

\section{JULY}

First, all the small flies that were taken in June are also taken in this month.

1. We have then the Orange-FLy; the dubbing of orange wool, and the wing, of a black feather.

2. Also a little White-DUN ; the body made of white mohair, and the wings, blue, of a heron's feather.

3. We have likewise this month a WASP-FLY; made either of a dark brown dubbing, or else the fur of a black cat's tail, ribbed about with yellow silk; and the wing, of the gray feather of a mallard.

4. Another fly taken this month is a Black Hackle; the body made of the whirl of a peacock's feather, and a black hackle-feather on the top.

5. We have also another, made of a peacock's whirl without wings.

6. Another fly also is taken this month, called the SHELL-FLY; the dubbing of yellow-green Jersey-wool, and a little white hog's hair mixed, which I call the PALM-FLY, and do believe it is taken for a palm, that drops off the willows into the water; for this fly I have seen trouts take little pieces of moss, as they have swam down the river; by which I conclude that the best way to hit the right colour is to compare your dubbing with the moss, and mix the colours as near as you can.

7. There is also taken, this month, a Black Blue Dun; the dubbing of the fur of a black rabbit mixed with a little yellow; the wings, of the feather of a blue pigeon's wing.

[I will add to the above four very killing flies for July.

No. 1. BLACK ANT-FLY. - Wings, any light-blue feather ; body, thin in the middle, but thick at shoulder and tail, resembling the body of an ant, and made of black ostrich 
harl; legs, two laps of very dark-brown hackle, close under wings. Hook, 10.

No. 2. RED ANr-FLY.-Wings, a young starling's wing-feather; body, made of the same shape as before, but with bright bronze peacock's harl; legs, bright red cock's hackle. Hooks, 10 and 11. These two flies are attractive this month and the two following on dark, warm days.

No. 3. Wings, a lark's wing-feather, dyed a pale yellow ; body, yellow martin's fur ; legs, a small honey-dun hackle. Hook, 12. A famous summer-fly at low and clear water.

No. 4. Wings, top fibres of the hen-pheasant's wing; body, brown mohair mixed with a little bright-coloured hare's ear fur; legs, gray throat-feather of the partridge. Hooks, 11 and 12.-E.]

\section{AUGUST}

The same flies with July.

1. Then another ANT-FLY, the dubbing of the black brown hair of a cow, some red wrapt in for the tag of his tail, and a dark wing; a killing fly.

2. Next a fly called the FERN-FLY, the dubbing of the fur of a hare's neck, that is of the colour of fern, or bracken, with a darkish gray wing of a mallard's feather; a killer too.

3. Besides these we have a White Hackle, the body of white mohair, and wrapped about with a white hacklefeather, and this is assuredly taken for thistle-down.

4. We have also this month a HARRY-LONG-LEGS, the body made of bear's-dun, and blue wool mixt, and a brown hackle-feather over all.

Lastly. In this month all the same Browns and Duss are taken that were taken in May.

[Small brown and black palmers will kill well this month. The two following are standard patterns for August:-

No. 1. Wings, fibres of a brown hen's wing-feather; body, brown floss silk ribbed with bright yellow tying silk ; legs, brown hackle ; tail, two hairs of a black rabbit's whiskers. Hook, 10. 
No. 2. Body, cinnamon-brown mohair; wings, reddish feather of woodcock's wing; legs, cinnamon hackle. Hook, as before.-E.]

\section{SEPTEMBER}

This month the same flies are taken that are taken in April.

1. To which I shall only add a Camel-Brown FLY, the dubbing pulled out of the lime of a wall, whipped about with red silk, and a darkish gray mallard's feather for the wing.

2. And one other for which we have no name; but it is made of the black hair of a badger's skin, mixed with the yellow softest down of a sanded hog.

\section{OCTOBER}

The same flies are taken this month that were taken in March.

\section{NOVEMBER}

The same flies that were taken in February, are taken this month also.

[For October and November, I would recommend small duns, and some of the flies named for April. For September, and for July and August, I recommend flve flies of great attractiveness :-

No. 1. Wings, a mixture of the nbres of the red and gray tail-feathers of the partridge; body, cinnamonbrown mohair; legs, an amber-dyed hackle, from tail to wings ; tail, two fibres of the hackle. Hook, 10.

No. 2. Wings, starling's feather; body, golden olive mohair; legs, hackle of the same colour; gold tip. Hook, as before.

No. 3. Wings, a mixture of the starling's wing-feather and partridge gray tail-feather; body, bronze harl, with an orange floss silk tag, gold tip ; legs, black-red hackle. Hooks, 8 and 10. This fly is named the "Governor."

No. 4. Wings, the top, beautiful green fibres of the peacock's moon-feather; body, bright bronze peacock's 
harl ; legs, sometimes a furnace hackle, at others a pure black one. Hooks, 10 and 11.

No. 5. Wings, a mixture of starling's wing, and brown mottled mallard feather; body, olive-green mohair ; legs, hackle of same colour, and gold tip. Hook, as before.

Reader, I have now added to Cotton's monthly lists of trout and grayling flies, the very best modern patterns. I have fished, in my time, with the great majority of them. I know by experience their captivating qualities, and I recommend them confidently to all fly-fishers for fresh water salmonidæ.-E.]

\section{DECEMBER}

Few men angle with the fly this month, no more than they do in January ; but yet, if the weather be warm (as I have known it sometimes in my life to be, even in this cold country, where it is least expected) then a Brown, that looks red in the hand, and yellowish betwixt your eye and the sun, will both raise and kill in a clear water and free from snow-broth; but, at the best, it is hardly worth a man's labour.

And now, Sir, I have done with fly-fishing, or angling at the top, excepting, once more, to tell you, that of all these (and I have named you a great many very killing flies) none are fit to be compared with the Drake and STONE-FLy, both for many and for very great fish; and yet there are some days that are by no means proper for the sport. And in a calm you shall not have near so much sport, even with daping, as in a whistling gale of wind, for two reasons, both because you are not then soeasily discovered by the fish, and also because there are then but few flies that can lie upon the water; for where they have so much choice, you may easily imagine they will not be so eager and forward to rise at a bait, that both the shadow of your body, and that of your rod, nay of your very line, in a hot calm day, will, in spite of your best caution, render suspected to them; but even then, in swift streams, or by sitting down patiently behind a willow 
bush, you shall do more execution than at almost any other time of the yeár with any other fly; though one may sometimes hit of a day, when he shall come home very well satisfied with sport with several other flies: but with these two, the GREEN-Drake and the STONEFLY, I do verily believe I could, some days in my life, had I not been weary of slaughter, have loaden a lusty boy; and have sometimes, I do honestly assure you, given over upon the mere account of satiety of sport; which will be no hard matter to believe, when I likewise assure you, that with this very fly, I have in this very river that runs by us, in three or four hours taken thirty, five and thirty, and forty $\mathrm{cf}$ the best trouts in the river. What shame and pity it is then, that such a river should be destroyed by the basest sort of people, by those unlawful ways of fire and netting in the night, and of damming, groping, spearing, hanging, and hooking by day, which are now grown so common, that, though we have very good laws to punish such offenders, every rascal does it, for aught I see, impunè.

To conclude, I cannot now in honesty but frankly tell you, that many of these flies I have named, at least so made as we make them here, will peradventure do you no great service in your southern rivers; and will not conceal from you, but that I have sent flies to several friends in London, that for aught I could ever hear, never did any great feats with them; and therefore if you intend to profit by my instructions, you must come to angle with me here in the Peak; and so, if you please, let us walk up to supper, and to-morrow, if the day be windy, as our days here commonly are, 'tis ten to one but we shall take a good dish of fish for dinner! 


\section{CHAPTER IX}

\section{[Cbird \$ay]}

Prsc. A good day to you, Sir; I see you will always be stirring before me.

Viat. Why, to tell you the truth, I am so allured with the sport I had yesterday, that I long to be at the river again; and when I heard the wind sing in my chamber window, could forbear no longer, but leap out of bed, and had just made an end of dressing myself as you came in.

Pisc. Well, I am both glad you are so ready for the day, and that the day is so fit for you; and look you, I have made you three or four flies this morning; this silver-twist hackle, this bear's dun, this light brown, and this dark brown, any of which I dare say will do; but you may try them all, and see which does best; only I must ask your pardon that I cannot wait upon you this morning, a little business being fallen out, that for two or three hours will deprive me of your company : but I'll come and call you home to dinner, and my man shall attend you.

Viat. Oh, Sir, mind your affairs by all means. Do but lend me a little of your skill to these fine flies, and, unless it have forsaken me since yesterday, I shall find luck of my own, I hope, to do something.

PIsc. The best instruction I can give you, is, that seeing the wind curls the water, and blows the right way, you would now angle up the still deep to-day; for betwixt the rocks where the streams are, you will find 
it now too brisk ; and besides, I would have you take fish in both waters.

VIAT. I'll obey your direction, and so good morning to you. Come, young man, let you and I walk together. But hark you, Sir, I have not done with you yet; I expect another lesson for angling at the bottom, in the afternoon.

Pisc. Well, Sir, I'll be ready for you. 


\section{CHAPTER $\mathrm{X}$}

\section{[حbiro Фay]}

Pisc. Oh, Sir, are you returned ? you have but just prevented me. I was coming to call you.

VIAT. I am glad then I have saved you the labour.

PIsc. And how have you sped ?

Viat. You shall see that, Sir, presently; look you, Sir, here are three brace of trouts, one of them the biggest but one that ever I killed with a fly in my life; and yet I lost a bigger than that, with my fly to boot; and here are three graylings, and one of them longer by some inches than that I took yesterday, and yet I thought that a good one too.

Pisc. Why you have made a pretty good morning's work on't; and now, Sir, what think you of our River Dove?

Viat. I think it to be the best trout river in England; and am so far in love with it, that if it were mine, and that I could keep it to myself, I would not exchange that water for all the land it runs over, to be totally debarred from it.

Pisc. That compliment to the river, speaks you a true lover of the art of angling; and now, Sir, to make part of amends for sending you so uncivilly out alone this morning, I will myself dress you this dish of fish for your dinner; walk but into the parlour, you will find one book or other in the window to entertain you the while, and you shall have it presently.

VIAT. Well, sir, I obey you.

PISc. Look you, Sir, have I not made haste? 
Viat. Believe me, Sir, that you have; and it looks so well, I long to be at it.

PIsc. Fall to then; now, Sir, what say you, am I a tolerable cook or no ?

Viat. So good a one, that I did never eat so good fish in my life. This fish is infinitely better than any I ever tasted of the kind in my life; 'tis quite another thing than our trouts about London.

PIsc. You would say so, if that trout you eat of were in right season: but pray eat of the grayling, which upon my word, at this season, is by much the better fish.

VIAT. In earnest and so it is : and I have one request to make to you, which is, that as you have taught me to catch trout and grayling, you will now teach me how to dress them as these are drest, which questionless is of all other the best way.

Pisc. That I will, Sir, with all my heart, and am glad you like them so well as to make that request, and they are drest thus :

Take your trout, wash, and dry him with a clean napkin ; then open him, and having taken out his guts, and all the blood, wipe him very clean within, but wash him not, and give him three scotches with a knife to the bone, on one side only. After which take a clean kettle, and put in as much hard stale beer (but it must not be dead), vinegar, and a little white wine and water as will cover the fish you intend to boil ; then throw into the liquor a good quantity of salt, the rind of a lemon, a handful of sliced horseradish root, with a handsome light faggot of rosemary, thyme, and winter savory. Then set your kettle upon a quick fire of wood: and let your liquor boil up to the height before you put in your fish: and then, if there be many, put them in one by one, that they may not so cool the liquor as to. make it fall. And whilst your fish is boiling, beat up the 
butter for your sauce with a ladle full or two of the liquor it is boiling in. And being boiled enough, immediately pour the liquor from the fish : and being laid in a dish, pour your butter upon it; and strewing it plentifully over with shaved horseradish, and a little pounded ginger, garnish the sides of your dish, and the fish itself, with a sliced lemon or two, and serve it up.

A grayling is also to be dressed exactly after the same manner, saving that he is to be scaled, which a trout never is : and that must be done either with one's nails, or very lightly and carefully with a knife, for fear of bruising the fish. And note, that these kinds of fish, a trout especially, if he is not eaten within four or five hours after he be taken, is worth nothing.

But come, Sir, I see you have dined; and therefore, if you please, we will walk down again to the little house, and there I will read you a lecture of angling at the bottom. 


\section{CHAPTER XI}

\section{[Tbiro Фay]}

Viat. So, Sir, now we are here, and set, let me have my instructions for angling for trout and grayling at the bottom; which though not so easy, so cleanly, nor (as 'tis said) so genteel a way of fishing as with a fly, is yet, if I mistake not, a good holding way, and takes fish when nothing else will.

Pisc. You are in the right, it does so : and a worm is so sure a bait at all times, that, excepting in a flood, I would I had laid a thousand pounds that I killed fish, more or less with it, winter or summer, every day throughout the year; those days always excepted, that upon a more serious account always ought so to be. But not longer to delay you, I will begin, and tell you, that angling at the bottom is also commonly of two sorts; and yet there is a third way of angling with a ground-bait, and to very great effect too, as shall be said hereafter ; namely, by hand, or with a cork or float.

That we call angling by hand is of three sorts.

The first, with a line about half the length of the rod, a good weighty plumb, and three hairs next the hook, which we call a running-line, and with one large brandling, or a dew-worm of a moderate size, or two small ones of the first, or any other sort, proper for a trout, of which my father Walton has already given you the names, and saved me a labour ; or, indeed, almost any worm whatever; for if a trout be in the humour to bite, it must be such a worm as I never yet saw, that he will refuse; and if you fish with two, you are then to bait 
your hook thus. You are first to run the point of your hook in at very head of your first worm, and so down through his body, till he be past the knot, and then let it out, and strip the worm above the arming, that you may not bruise it with your fingers till you have put on the other, by running the point of the hook in below the knot, upwards through his body towards his head, till it be but just covered with the head; which being done, you are then to slip the first worm down over the arming again, till the knots of both worms meet together.

The second way of angling by hand, and with a running line, is with a line something longer than the former, and with tackle made after this same manner. At the utmost extremity of your line, where the hook is always placed in all other ways of angling, you are to have a large pistol or carabine bullet, into which the end of your line is to be fastened with a peg or pin, even and close with the bullet; and, about half a foot above that, a branch of line, of two or three handfuls long, or more for a swift stream, with a hook at the end thereof, baited with some of the fore-named worms, and, another, half a foot above that, another armed and baited after the same manner, but with another sort of worm, without any lead at all above: by which means you will always certainly find the true bottom in all depths; which with the plumbs upon your line above you can never do, but that your bait must always drag whilst you are sounding (which in this way of angling must be continually), by which means you are like to have more trouble, and peradventure worse success. And both these ways of angling at the bottom are most proper for a dark and muddy water, by reason, that in such a condition of the stream, a man may stand as near as he will, and neither his own shadow, nor the roundness of his tackle will hinder his sport. 
The third way of angling by hand with a ground-bait, and by much the best of all other, is, with a line full as long, or a yard and a half longer than your rod; with no more than one hair next the hook, and for two or three lengths above it; and no more than one small pellet or shot for your plumb ; your hook, little; your worms, of the smaller brandlings, very well scoured, and only one upon your hook at a time; which is thus to be baited. The point of your hook is to be put in at the very tag of his tail, and run up his body quite over all the arming, and still stripped on an inch at least upon the hair, the head and remaining part hanging downward: and with this line and hook thus baited you are evermore to angle in the streams, always in a clear rather than a troubled water, and always up the river, still casting out your worm before you with a light one-handed rod, like an artificial fly; where it will be taken sometimes at the top, or within a very little of the superficies of the water, and almost always before that light plumb can sink it to the bottom, both by reason of the stream, and also, that you must always keep your worm in motion by drawing still back towards you, as if you were angling with a fly; and believe me, whoever will try it, shall find this the best way of all other to angle with a worm, in a bright water especially; but then his rod must be very light and pliant, and very true and finely made, which, with a skilful hand, will do wonders, and in a clear stream is undoubtedly the best way of angling for a trout or grayling with a worm, by many degrees, that any man can make choice of, and of most ease and delight to the angler. To which, let me add, that if the angler be of a constitution that will suffer him to wade, and will slip into the tail of a shallow stream, to the calf of the leg or the knee, and so keep off the bank, he shall almost take what fish he pleases.

The second way of angling at the bottom, is with a 
cork or float; and that is also of two sorts; with a worm, or with a grub or cadis.

With a worm, you are to have your line within a foot, or a foot and a half as long as your rod; in a dark water, with two, or if you will with three, but in a clear water, never with above one hair next the hook, and two or three for four or five lengths above it, and a worm of what size you please, your plumbs fitted to your cork, your cork to the condition of the river, that is, to the swiftness, or slowness of it; and both, when the water is very clear, as fine as you can; and then you are never to bait with above one of the lesser sort of brandlings; or, if they are very little ones indeed, you may then bait with two, after the manner before directed.

When you angle for a trout, you are to do it as deep, that is, as near the bottom as you can, provided your bait do not drag ; or if it do, a trout will sometimes take it in that posture: if for a grayling, you are then to fish further from the bottom, he being a fish that usually swims nearer to the middle of the water, and lies always loose ; or however, is more apt to rise than a trout, and more inclined to rise than to descend even to a groundbait.

With a grub or cadis, you are to angle with the same length of line, or if it be all out as long as your rod it is not the worse, with never above one hair, for two or three lengths next the hook, and with the smallest cork or float, and the least weight of plumb you can that will but sink, and that the swiftness of your stream will allow; which also you may help, and avoid the violence of the current, by angling in the returns of a stream, or the eddies betwixt two streams, which also are the most likely places wherein to kill a fish in a stream, either at the top or bottom.

Of grubs for a grayling, the ash-grub, which is plump, milk-white, bent round from head to tail, and exceeding 
tender, with a red head, or the dock-worm, or grub of a pale yellow, longer, lanker, and tougher than the other, with rows of feet all down his belly, and a red head also, are the best; I say, for a grayling, because although a trout will take both these, the ash-grub especially, yet he does not do it so freely as the other, and I have usually taken ten graylings for one trout with that bait; though if a trout come, I have observed that he is commonly a very good one.

These baits we usually keep in bran, in which an ashgrub commonly grows tougher, and will better endure baiting ; though he is yet so tender, that it will be necessary to warp in a piece of a stiff hair with your arming, leaving it standing out about a straw-breadth at the head of your hook, so as to keep the grub either from slipping totally off when baited, or at least down to the point of the hook; by which means your arming will be left wholly naked and bare, which is neither so sightly, nor so like to be taken : though to help that, which will however very oft fall out, I always arm the hook I design for this bait with the whitest horse-hair I can choose, which itself will resemble, and shine like that bait, and consequently will do. more good, or less harm, than an arming of any other colour. These grubs are to be baited thus: the hook is to be put under the head or chaps of the bait, and guided down the middle of the belly-without suffering it to peep out by the way, for then the ash-grub especially will issue out water and milk, till nothing but the skin shall.remain, and the bend of the hook will appear black through it,- - till the point of your hook come so low, that the head of your bait may rest, and stick upon the hair that stands out to hold it; by which means it can neither slip of itself, neither will the force of the stream, nor quick pulling out, upon any mistake, strip it off.

Now the cadis, or cod-bait, which is a sure killing bait, and for the most part, by much surer than either of the 
other, may be put upon the hook, two or three together, and is sometimes, to very great effect, joined to a worm, and sometimes to an artificial fly to cover the joint of your hook ; but is always to be angled with at the bottom, when by itself especially, with the finest tackle ; and is for all times of the year, the most holding bait of all other whatever, both for trout and grayling.

There are several other baits besides these few I have named you, which also do very great execution at the bottom, and some that are peculiar to certain countries and rivers, of which every angler may in his own place make his own observation; and some others that I do not think fit to put you in mind of, because I would not corrupt you, and would have you, as in all things else I observe you to be a very honest gentleman, a fair angler. And so much for the second sort of angling for a trout at the bottom.

Viat. But, Sir, I beseech you give me leave to ask you one question : is there no art to be used to worms, to make them allure the fish, and in a manner compel them to bite at the bait?

PIsc. Not that I know of ; or did I know any such secret, I would not use it myself, and therefore would not teach it you. Though I will not deny to you, that in my younger days, I have made trial of oil of osprey, oil of ivy, camphire, assafœtida, juice of nettles, and several 'other devices that I was taught by several anglers I met with; but could never find any advantage by them; and can scarce believe there is anything to be done that way: though I must tell you, I have seen some men who I thought went to work no more artificially than I, and have yet, with the same kind of worms I had, in my own sight taken five, and sometimes ten to one. But we'll let that business alone, if you please; and because we have time enough, and that I would deliver you from the trouble of any more lectures, I will, if you please, proceed to 
the last way of angling for a trout or grayling, which is in the middle; after which I shall have no more to trouble you with.

VIAT. 'Tis no trouble, Sir, but the greatest satisfaction that can be; and I attend you. 


\section{CHAPTER XII}

\section{[ Tbird Day]}

Pisc. Angling in the middle, then, for a trout or grayling, is of two sorts ; with a penk or minnow for a trout ; or with a worm, grub, or cadis, for a grayling.

For the first. It is with a minnow, half a foot or a foot within the superficies of the water. And as to the rest that concerns this sort of angling, I shall wholly refer you to Mr. Walton's directions, who is undoubtedly the best angler with a minnow in England; only, in plain truth, I do not approve of those baits he keeps in salt, unless where the living ones are not possibly to be had (though I know he frequently kills with them, and, peradventure, more than with any other; nay, I have seen him refuse a living one for one of them) ; and much less of his artificial one; for though we do it with a counterfeit fly, methinks it should hardly be expected that a man should deceive a fish with a counterfeit fish.* Which having said, I shall only add (and that out of my own experience), that I do believe a bull-head, with his gill-fins cut off (at some times of the year especially), to be a much better bait for a trout than a minnow, and a loach much better than that: to prove which I shall only tell you, that I have much oftener taken trouts with a bull-head or a loach in their throats, for there a trout has questionless his first digesiion,

* Counterfeit fish, or artificial fish-baits, are now so well made, that in spinning $I$ frequently use them in preference to the natural fish-bait; and in slightly discoloured water I always prefer them. They spin better, and will take a great many fish before they are injured, which is a great convenience, obviating the necessity of constantly, after a run or a kill, putting on a fresh bait, which you must do if you spin with the natural fish-bait.-E. 
than a minnow; and that one day especially, having angled a good part of the day with a minnow, and that in as hopeful a day, and as fit a water, as could be wished for that purpose, without raising any one fish ; I at last fell to it with the worm, and with that took fourteen in a very short space; amongst all which, there was not, to my remembrance, so much as one, that had not a loach or two, and some of them three, four, five, and six loaches, in his throat and stomach; from whence I concluded, that had I angled with that bait, I had made a notable day's work of it.

But after all, there is a better way of angling with a minnow, than perhaps is fit either to teach or to practise ; to which I shall only add, that a grayling will certainly rise at, and sometimes take a minnow, though it will be hard to be believed by any one, who shall consider the littleness of that fish's mouth, very unfit to take so great a bait : but it is affirmed by many, that he will sometimes do it ; and I myself know it to be true ; for though I never took a grayling so, yet a man of mine once did, and within so few paces of me, that I am as certain of it, as I can be of anything I did not see, and, which made it appear the more strange, the grayling was not above eleven inches long.

I must here also beg leave of your master, and mine, not to controvert, but to tell him, that I cannot consent to his way of throwing in his rod to an over-grown trout, and afterwards recovering his fish with his tackle. For though I am satisfied he has sometimes done it, because he says so, yet I have found it quite otherwise; and though I have taken with the angle, I may safely say, some thousands of trouts in my life, my top never snapt, (though my line still continued fast to the remaining part of my rod by some lengths of line curled round about my top, and there fastened, with waxed sills, against such an accident), nor my hand never slacked, or slipped by 
any other chance, but I almost always infallibly lost my fish, whether great or little, though my hook came home again. And I have often wondered how a trout should so suddenly disengage himself from so great a hook as that we bait with a minnow, and so deep bearded as those hooks commonly are, when I have seen by the forenamed accidents, or the slipping of a knot in the upper part of the line, by sudden and hard striking, that though the line has immediately been recovered, almost before it could be drawn into the water, the fish cleared and gone in a moment. And yet, to justify what he says, I have sometimes known a trout, having carried away a whole line, found dead three or four days after, with the hook fast sticking in him; and then it is to be supposed he had gorged it, which a trout will do, if you be not too quick with him when he comes at a minnow, as sure and much sooner than a pike : and I myself have also, once or twice in my life, taken the same fish, with my own fly sticking in his chaps, that he had taken from me the day before, by the slipping of a hook in the arming. But I am very confident a trout will not be troubled two hours with any hook that has so much as one handful of line left behind with it, or that is not struck through a bone, if it be in any part of his mouth only : nay, I do certainly know, that a trout, so soon as ever he feels himself pricked, if he carries away the hook, goes immediately to the bottom, and will there root, like a hog upon the gravel, till he either rub out or break the hook in the middle. And so much for this sort of angling in the middle for a trout.

The second way of angling in the middle, is with a worm, grub, cadis, or any other ground-bait for a grayling; and that is with a cork, and a foot from the bottom, a grayling taking it much better there than at the bottom, as has been said before; and this always in a clear water, and with the finest tackle. 
To which we may also, and with very good reason, add the third way of angling by hand with a ground-bait, as a third way of fishing in the middle, which is common to both trout and grayling, and, as I said before, the best way of angling with a worm, of all other I ever tried whatever.

And now, Sir, 'I have said all I can at present think of concerning angling for a trout and grayling, and I doubt not have tired you sufficiently ; but I will give you no more trouble of this kind, whilst you stay, which I hope will be a good while longer.

VIAT. That will not be above a day longer; but if I live till May come twelvemonth, you are sure of me again, either with my master Walton, or without him; and in the meantime shall acquaint him how much you have made of me for his sake, and I hope he loves me well enough to thank you for it.

PIsc. I shall be glad, Sir, of your good company at the time you speak of, and shall be loath to part with you now; but when you tell me you must go, I will then wait upon you more miles on your way than I have tempted you out of it, and heartily wish you a good journey. 




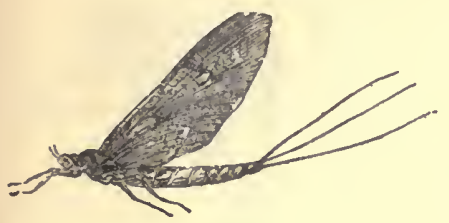

1

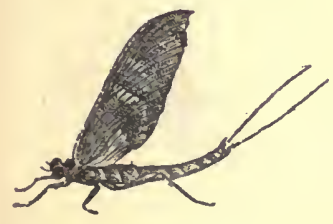

3

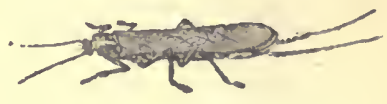

2

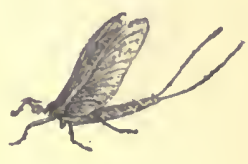

4

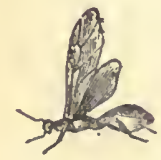

5

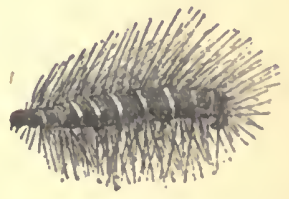

6 


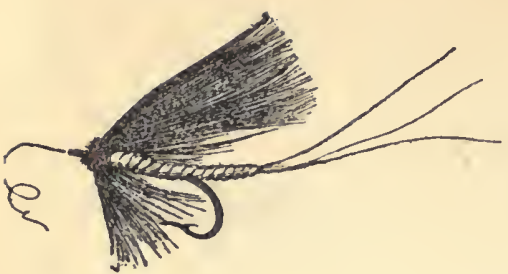

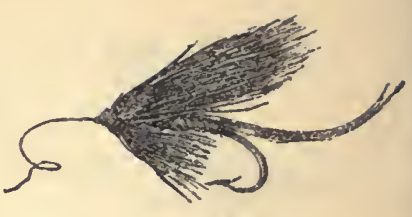
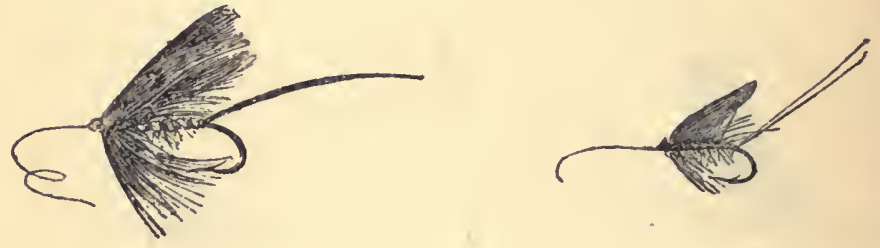

3

4

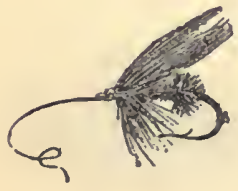

5

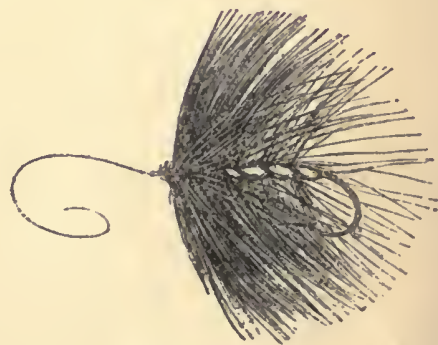

6 


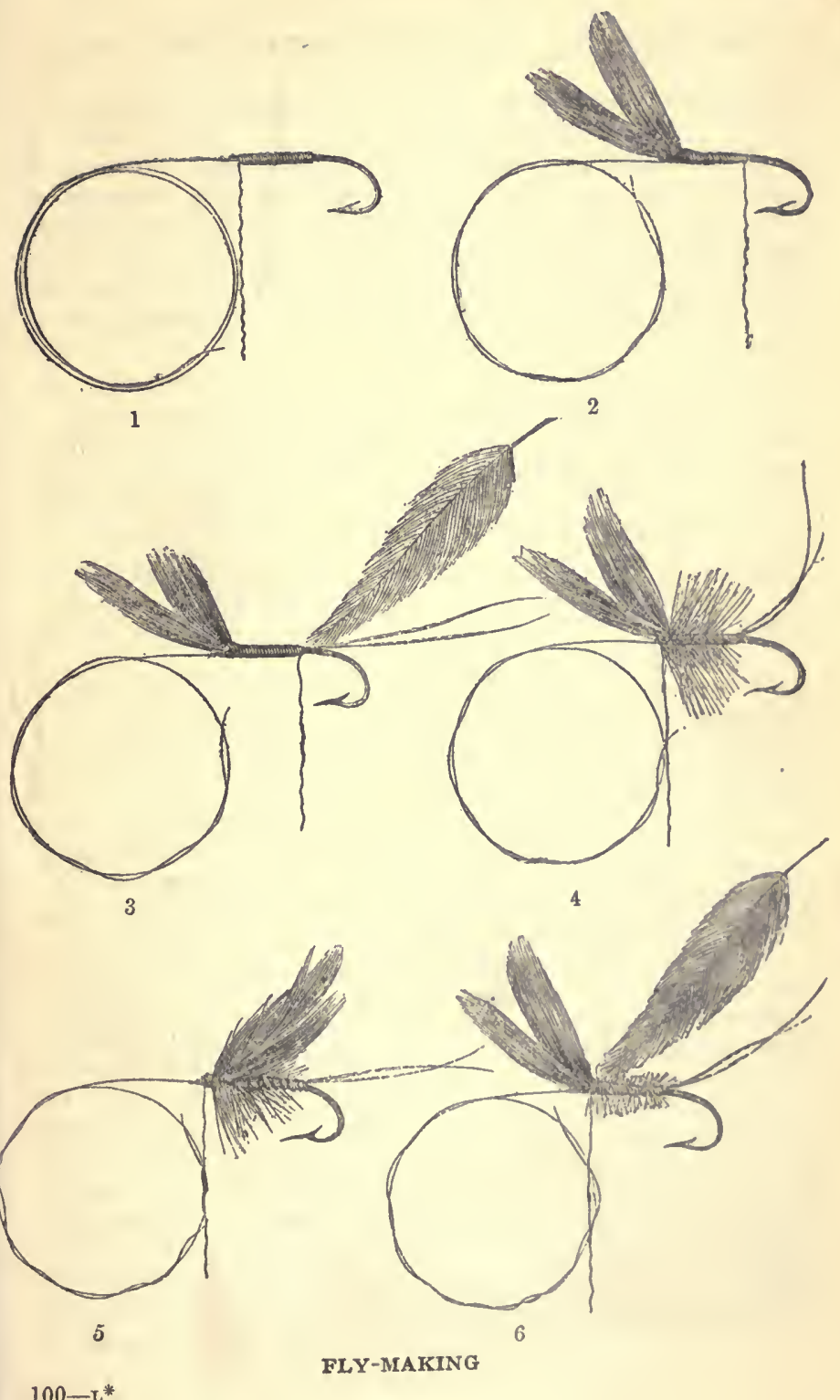




\section{EXPLANATION OF THE PLATE OF NATURAL FLIES}

Is this plate the examiner will see six representations, taken from life, of insects used in fly-fishing.

No. 1. The May-fly or Green-drake (ephemera vulgata) stands at the head of its tribe. The ephemeræ are extremely numerous, of various sizes and colours, appearing particularly in the summer and autumn months. Their wings stand upright and they have whisks or tails. Of all flies these are the most useful to the angler. As their name inplies, they are very short-lived, but fresh tribes of them replace those which die in a day.

No. 2. Is the Stone-fly, and the largest of its tribe (phryganeæ). They are considered spring-flies, but they are produced throughout the year. Generally speaking they have flat wings, but that is not a specific characteristic, because the house-fly (musca) and other flies have flat wings also. The flies of this species proceed from water larvæ, and in angling importance stand next to the ephemeræ.

No. 3. Is the March-brown, or large dun ephemera. It is nearly as large as the May-fly, or ephemera vulgata, and in March and April is as great a favorite with trout, as the May-fly is in May or June. It is a fly I esteem very highly.

No. 4. Is a representation of a diptera or two-winged fly. These flies are generally small and have two upright wings. In shape and colour they much resemble the ephemeræ, and as baits they are equally captivating.

No. 5. Is the Ant-fly (formica). It is a late summer and early autumn fly. Its body resembles that of an ant. Hence its name. It is not a water-born fly, but a land-bred one. Its wings are transparent and feeble, and the slightest breeze wafts it on to the surface of rivers. Grayling take it eagerly, and so do roach and dace.

No. 6. Is a dark palmer, or representation of a dark caterpillar, with light ye'low circular bands round the body. Walton properly observes, " this is called a pilgrim or palmer-worm, for his very wandering life and various food: not contenting himself, as others do, with any one certain place for his abode, nor any certain kind of herb or flower for his feeding; but will boldly and disorderly wander up and down, and not endure to be kept to a diet, or fixed to a particular place." As caterpillars are of various sizes and colours, so are their artificial representations. They are good angling baits in the English rivers, but not so good either in Ireland or Scotland. Chub take them with great avidity. Made very large they will catch large Thames trout, and in the rivers of South Wales they are not bad baits for salmon.-E. 


\section{EXPLANATION OF -THE PLATE OF ARTIFICIAL FLIES}

The Second Plate shows six artificial representations of the flies in the first plate. The spectator will recognise a likeness in all of them, except in the second, the wings of which are too upright. In the water, however, those wings will lie flat. As artificial flies they are good models. In the palmer, No. 6, there is a slight defect near the bend of the hook. The fibres of the hackle-feather are not there divided with sufficient regularity. The palmer is made just as the fly No. 3 on the third plate is made, except that there is neither tail nor wings.-E.

\section{EXPLANATION OF THE PLATE OF FLY-MAKING}

We have here diagrams representing the artificial-fly in its several stages of fabrication.

No. 1. Is what is called the hook " armed," that is to say, the hook and gut-link tied or whipped together, preparatory to putting on the wings of the fly. Hook and gut are whipped together thus :You wax a piece of fine tying silk, about a foot or eighteen inches in length; then take your hook by the bend between the thumb and forefinger of your left hand; make a whip or two of the waxed silk round the bare shank of the hook nearly opposite to the barb, and having done so, place your gut under the shank up to the whipping, which whipping or winding of the silk you must continue over gut and shank of hook up almost to the end. Make a slip-knot, and allow the silk to depend. Now for the wings, see

No. 2. The wings here are partly set on. To do so, you must strip irom the wing-feather of some small bird, using the longest fibres, a smallish bunch. You place them on the back of the shank of the hook, near its end, with their butts towards the bend of the hook; you tie them down with three or four whips or laps of the silk; you then cut away the fibres of the butt, and you wind your silk down the shank to the spot at which you began the arming, and leave the silk depending.

No. 3. You here see the whisks or tail set on, and the hacklefeather tied by the point and ready to be wound up to the wings. The whisks and hackle-feather are whipped on after you have finished the operations necessary for No. 2, as already described. The back of the feather must be towards you. Take it by the bared stem, and wind regularly up the hook to the wings; wind so that the fibres will project like those of No. 4 or No. 5 . When you have wound the hackle-feather up the wings, fasten it down by two or three whips of 
the silk over it; make a slip-knot, cut away the end of the stem, leave the silk depend, and then you will have the representation marked-

No. 4. Now pass your silk between the division of the wings, round by the butt of the half-wing on the left side of the hook, and bring the silk back again between the division, and round by the butt of the half-wing next to you. Force the wings down, forwards towards the bend of the hook, and tie them down behind the shoulder, at which spot you must form the head of the fly, by three or four laps of the silk, and a couple of slip-knots, and then you will have diagram,

No. 5. In which you have only to cut away the silk, and put a drop of varnish on the cutting, to prevent the slip-knot from coming undone.

No. 6. Represents the hackle put on differently from the way shown at No. 3. The fibres seen in this diagram No. 6, round the shank of the hook, between the tail and the wings, are a body of dubbing, of mohair or fur, which has been twisted round the silk after the tail has been fastened on, and wound up to the wings; a slip-knot was then made, and superfluous dubbing taken away. The hackle-feather was then attached as you see, and wound round two, three, or four times at the wing; the stem of the hackle was then cut away, after having been tied down; and the wings arranged as directed at No. 4, as well as the head. When it is necessary to rib the body of the fly with gold or silver, twist or tinsel, tie it on immediately before your hackle, near the thick end of the tail, and then outside the tinsel tie your hackle; wind your tinsel regularly, for ribbing, up the body of the fly to the wings; fasten your tinsel down, and cut away the end. By its side wind afterwards your hackle. If no hackle is used, but simply dubbing for body, spin it on your silk and wind round shank from tail to shoulder of the fly. Lap tinsel or twist over it, picking out dubbing for legs, and to show the tinsel.

He who shall not be able to make a trout-fly, after studying these diagrams and directions, must be deficient either in brains or in manual dexterity.-E.

THE END 


\section{THE PEOPLE'S LIBRARY}

\section{THE \\ FIRST HUNDRED \\ VOLUMES}

A LIST FOR REFERENCE 


\section{THE PEOPLE'S LIBRARY *}

x. Treasure Island and Kidnapped-STEVENSON.

2. Adam Bede-ELIOT.

3. East Lynne-WOOD.

4. The Essays of Elia-LAMB.

5. Ivanhoe-SCOTT.

6. A Tale of Two Cities-DICKENS.

7. Poems, 1830-1865-TENNYSON.

8. Westward Ho !-KINGSLEY.

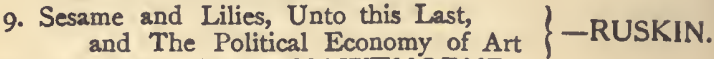

10. The Scarlet Letter-HAWTHORNE.

Ir. The Cloister and the Hearth-READE.

12. The Christmas Books-DICKENS.

13. Tom Brown's Schooldays-HUGHES.

14. King Solomon's Mines-HAGGARD.

I5. Poems (Selection, 1833-1865)-BROWNING.

16. John Halifax, Gentleman-CRAIK.

17. Essays and other Writings-BACON.

18. The Mill on the Floss-ELIOT.

19. The Autocrat of the Breakfast Table-HOLMES.

20. Kenilworth-SCOTT.

21. Jane Eyre-BRONTE.

22. Robinson Crusoe-DEFOE.

23. Waverley-SCOTT.

24. The Old Curiosity Shop-DICKENS.

25. Essays and other Writings-EMERSON.

26. Cranford-GASKELL.

27. Silas Marner-ELIOT.

28. Poems (Selection)-LONGFELLOW.

29. The Last Days of Pompeii-LYTTON.

30. Esmond-THACKERAY.

3r. Pride and Prejudice-AUSTEN.

32. The Tower of London-AINSWORTH.

33. The Bible in Spain-BORROW.

34. The Last of the Mohicans-COOPER.

35. The Opium Eater and other Writings-DE QUINCEY.

36-39. Complete Works-SHAKESPEARE.

40. Barnaby Rudge-DICKENS.

4I. The Last of the Barons-LYTTON.

42. Fairy Tales (Selection)-ANDERSEN.

43. The Vicar of Wakefield and Poems-GOLDSMITH.

44. The Deerslayer-COOPER.

45. Sense and Sensibility-AUSTEN.

46. Poems and Songs-BURNS.

47. The Three Musketeers-DUMAS.

48. The Channings-WOOD.

49. The Ingoldsby Legends-BARHAM.

50. Oliver Twist-DICKENS.

\section{THE STANDARD}

" The paper, printing, and binding of each volume are excellently contrived and produced, and must inevitably give a book-lover genuine pleasure to examine and handle." 
51. The Little Minister-BARRIE.

52. Fairy Tales (Selected)-GRIMM.

53. Meditations-MARCUS AURELIUS.

54. Uncle Tom's Cabin-STOWE.

55. The History of Selborne-WHITE.

56. The Two Paths and Other Essays-RUSKIN.

57. The Pathfinder-COOPER.

58. Tales from Shakespeare-LAMB.

59. The Woman in White-COLLINS.

60. Sartor Resartus and Essays on Burns and Scott-CARLYLE.

6r. It is Never Too Late to Mend-READE.

62. The Pilgrim's Progress-BUNYAN.

63. Shirley-BRONTË.

64. Tales, Poems, and Sketches-BRET HARTE.

65. Hypatia-KINGSLEY.

66. Lectures and Essays-HUXLEY.

67. Handy Andy-LOVER.

68. Voyages of Discovery-COOK.

69. Mr. Midshipman Easy-MARRYAT.

70. Heroes and Hero Worship \& Essays on Goethe-CARLYLE.

7r. Masterman Ready-MARRYAT.

72. Our Village-MITFORD.

73. Origin of Species-DARWIN.

74. The Three Midshipmen-KINGSTON.

75. Galliver's Travels-SWIFT.

76. The Talisman-SCOTT.

77. Harold-LYTTON.

78. Plays-SHERIDAN.

79. Ravenshoe-H. KINGSLEY.

8o. Vanity Fair-THACKERAY.

8I. Peter the Whaler-KINGSTON.

82. Wonder Book and Tanglewood Tales-HAWTHORNE.

83. Charles O'Malley-LEVER.

84. Historical Essays \& Lays of Ancient Rome-MACAULAY.

85. Wnthering Heights-BRONTE.

86. Guy Mannering-SCOTT.

87. Hard Cash-READE.

88. Whitefriars-ROBINSON.

89. Poems-WHITMAN.

90. Legends-PROCTER.

91. Two Years Ago-KINGSLEY.

92. The Heart of Midlothian-SCOTT.

93. Barchester Towers-TROLLOPE.

94. Peter Simple-MARRYAT.

95. Life of Nelson-SOUTHEY.

96. Tales of Mystery and Imagination-POE.

97. Life of Christ-FARRAR.

98. Faust-GOETHE.

99. Swiss Family Robinson.

100. The Compleat Angler-WALTON. 



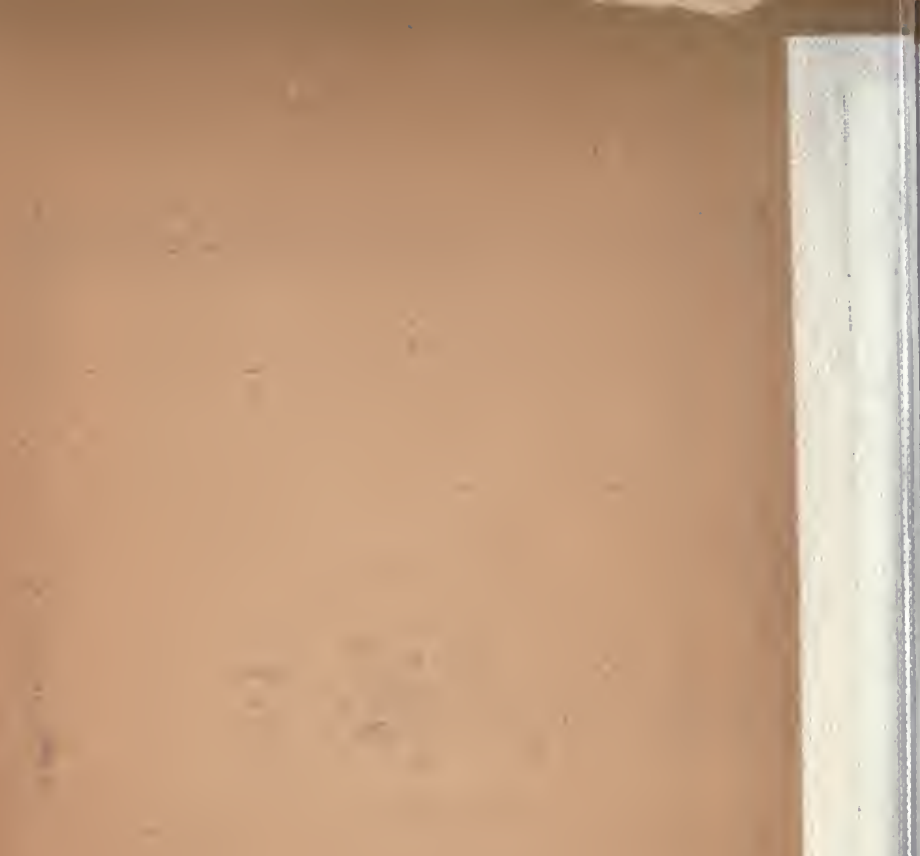
